\title{
ESTACAS ESCAVADAS COM BASE INJETADA
}

\section{Luciene Santos de Moraes}

Tese apresentada à Escola de Engenharia de São Carlos da Universidade de São Paulo, como parte dos requisitos para obtenção do título de Doutor em Ciências, Programa de Pósgraduação em Geotecnia

ORIENTADOR: Prof. Dr. José Carlos Angelo Cintra

São Carlos 



\section{FOLHA DE JULGAMENTO}

Candidato: Engenheiro LUCIENE SANTOS DE MORAES.

Tese defendida e julgada em 19/07/2010 perante a Comissão Julgadora:

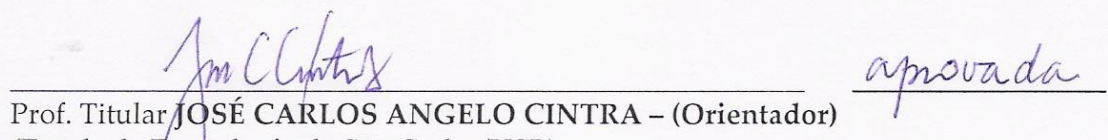

(Escola de Engenharia de São Carlos/USP)

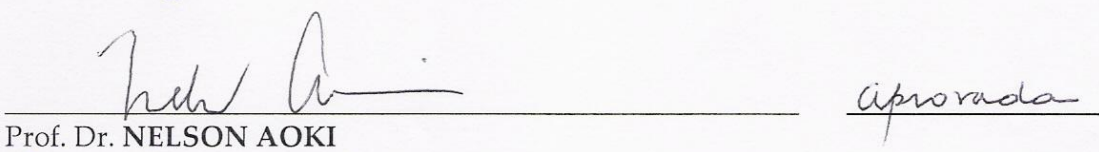

(Escola de Engenharia de São Carlos/USP)

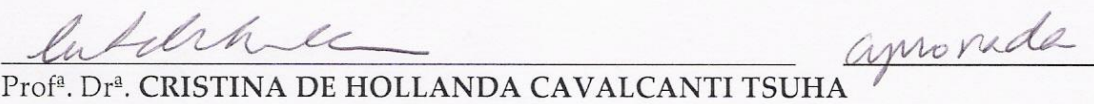
(Escola de Engenharia de São Carlos/USP)

\section{codefrilceouen de lol hi.}

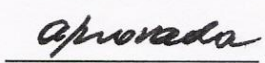

Prof. Dr. CARLOS JOSÉ MARQUES DA COSTA BRANCO

(Universidade Estadual de Londrina/UEL)
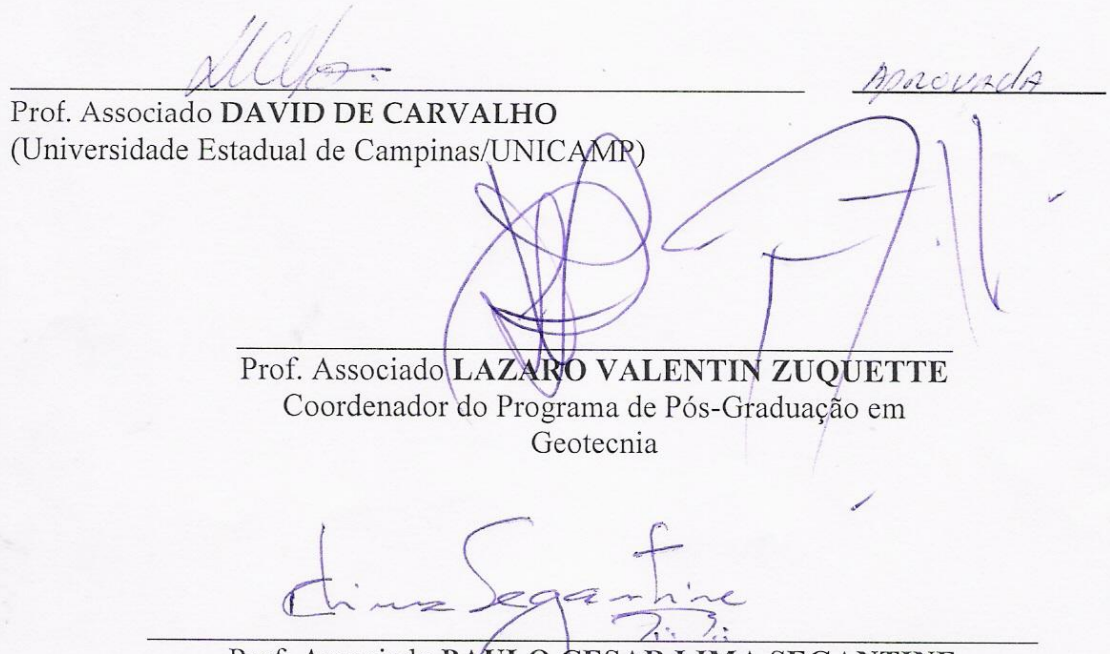

Prof. Associado PAULO CESAR LIMA SEGANTINE

Vice-Presidente da Comissão de Pós-Graduação 

Aos meus pais, irmãs e ao meu marido A Moacir Leite in memoriam 



\section{AGRADECIMENTOS}

Ao CNPq pela bolsa concedida.

Ao Prof. Dr. José Carlos Angelo Cintra pela valiosa orientação durante o desenvolvimento deste trabalho.

À E. G. Barreto pelo apoio na execução das injeções, especialmente a Gilmar Barreto pelas inúmeras ideias e sugestões.

Ao Prof. Dr. Nelson Aoki pelas importantes sugestões fornecidas no desenvolvimento desta pesquisa

Aos professores e funcionários do Departamento de Geotecnia da USP/São Carlos pela cooperação.

Aos amigos Wanessa, Dani Cenci, Nene, Thiago, Ju Lukiantchuki, Nestor, Rafaela, Aref, Damares, Lizandra, Márcia, Aline, Ana Elisa, Carla, Val e Cristina pelo companheirismo e inestimável apoio, principalmente durante a realização das provas de carga.

Especial agradecimento ao meu marido, Rogério, pelo constante incentivo, paciência e ajuda em tudo, até mesmo na realização das provas de carga. 



\section{RESUMO}

MORAES, L. S. Estacas Escavadas com Base Injetada. São Carlos, 2010. 154 p. Tese (doutorado) - Escola de Engenharia de São Carlos, Universidade de São Paulo.

Foram construídas bases injetadas próximas à superfície e estacas escavadas com base injetada no campo experimental de fundações do departamento de geotecnia da USP/São Carlos. As injeções de caldas de cimento portland foram realizadas como procedimento de melhoria do solo de apoio. Provas de carga estática em estruturas com e sem injeção determinaram a eficácia da solução de bases injetadas.

Simultaneamente às provas de carga, houve monitoração da sucção matricial atuante no solo, dando continuidade ao extenso programa de pesquisa realizado no Campo Experimental de Fundações da USP / São Carlos no tema da colapsibilidade.

Palavras-chave: prova de carga, injeções, solo colapsível. 



\section{ABSTRACT}

MORAES, L. S. Injected Toe Bored Piles. São Carlos, 2010. 154 p. Theses (doctorate) Escola de Engenharia de São Carlos, Universidade de São Paulo.

Injected elements close to surface and toe injected bored piles were built at USP/São Carlos experimental foundation field.

Under the foundations, portland cement grout was injected in order to improve soil and foundation bearing capacity. Load tests measured and determined the efficacy of the solution.

Along with the load tests, matric suction measurements were made, continuing the extensive research program in the USP/São Carlos experimental foundation field under the theme soil collapsibility.

Key words: Load test, injection, collapsible soil. 



\section{SUMÁRIO}

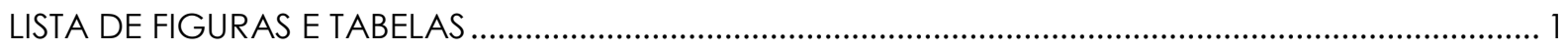

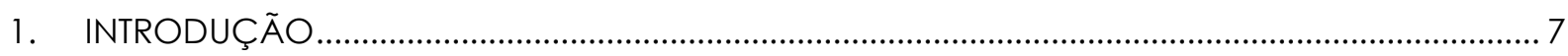

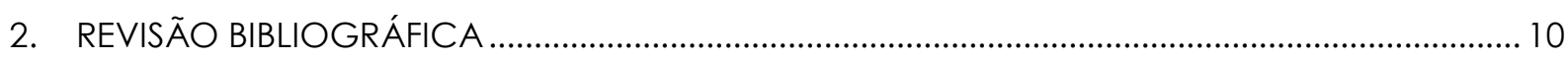

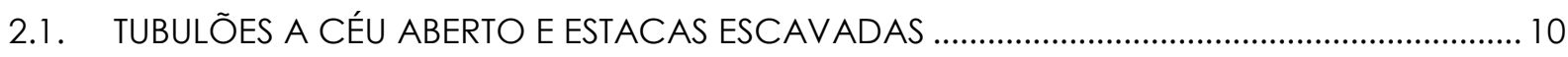

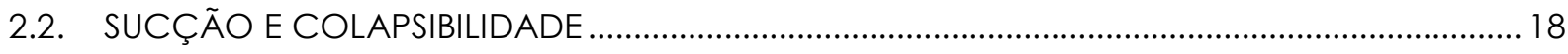

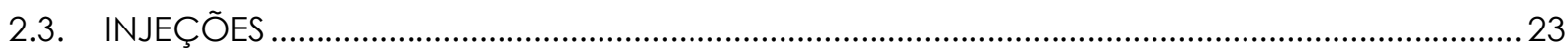

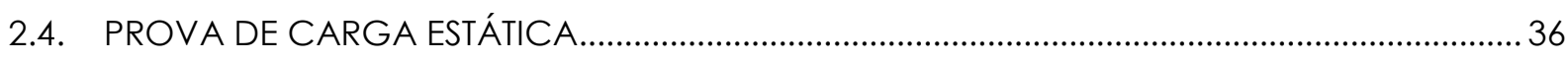

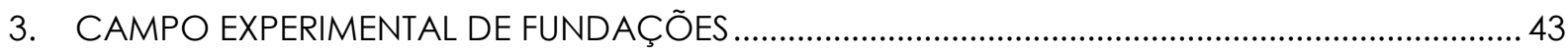

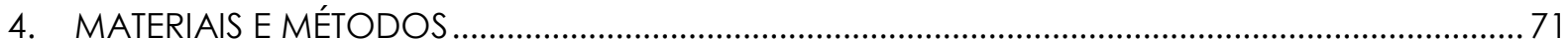

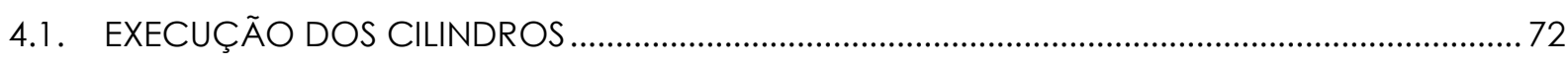

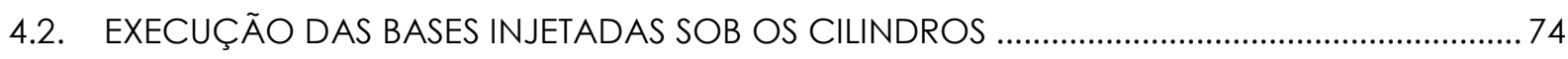

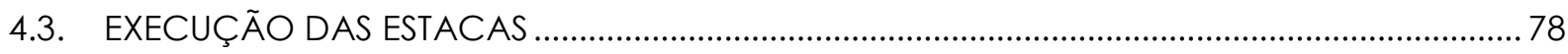

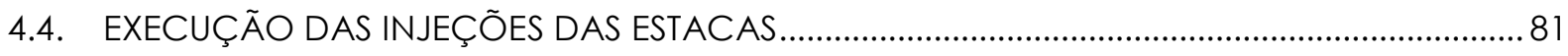

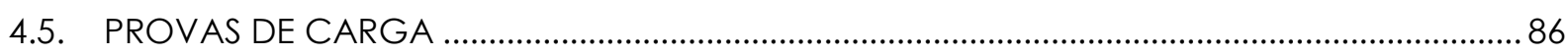

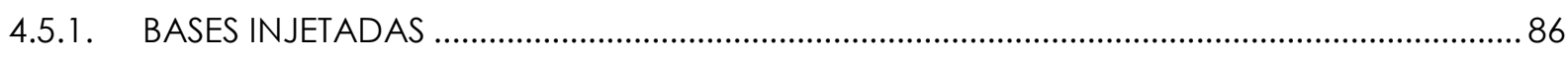

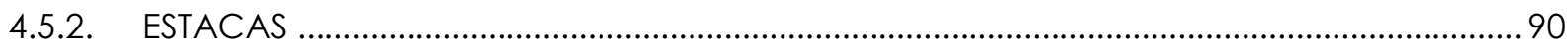

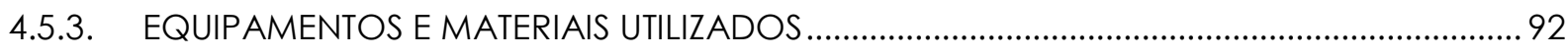

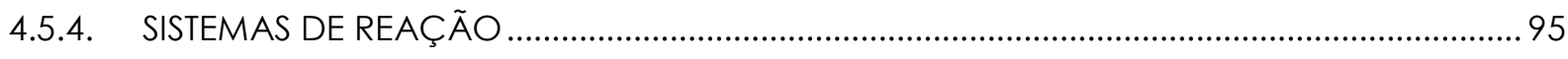

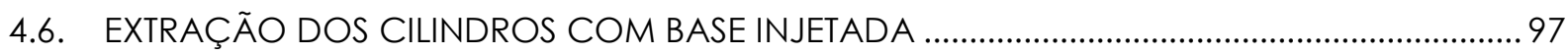

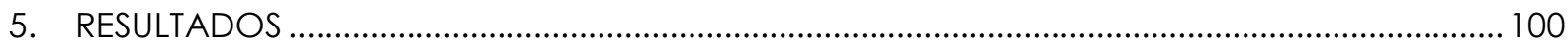

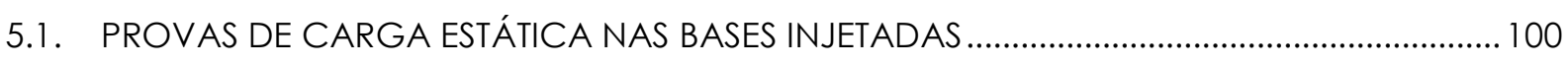

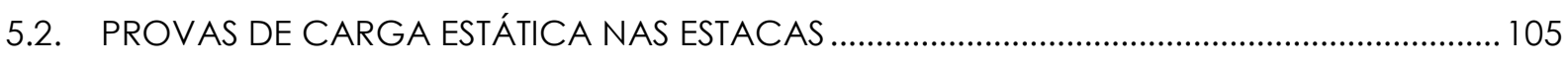

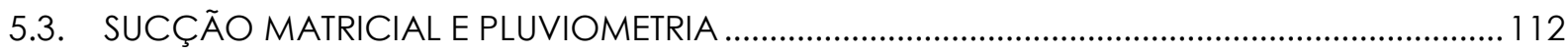

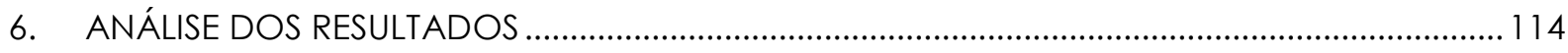

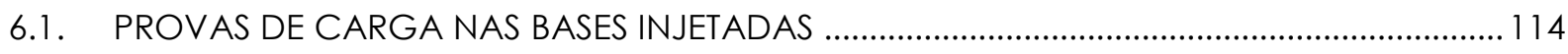

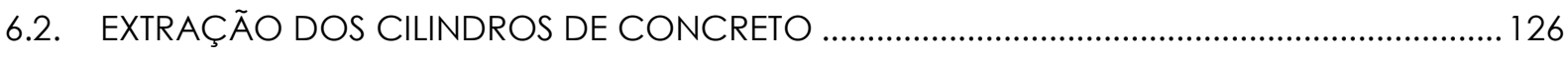

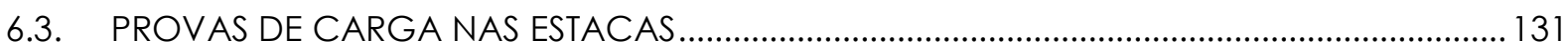


6.4. PRECIPITAÇÃO, NÍVEL D'ÁGUA E TENSIOMETRIA.

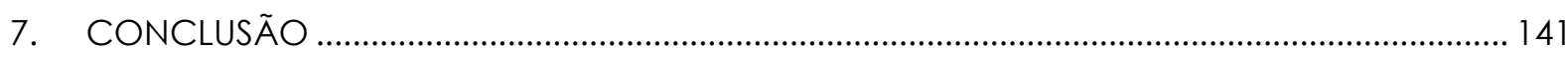

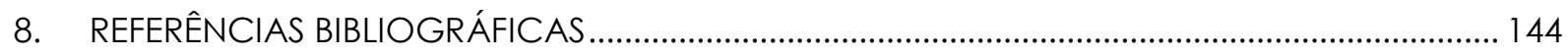




\section{LISTA DE FIGURAS E TABELAS}

Tabela 2.1 - Resultado das análises CAPWAP® de estacas escavadas (Branco, 2006) ............ 14

Figura 2.1 - Procedimentos Construtivos do Método SSM - MAN (Miki, 1979) .............................. 16

Figura 2.2 - Broca para alargamento da base de estacas escavadas (Mori \& Inamura, 1991)

Figura 2.3 - Variação da capacidade de carga de sapatas corridas em função da sucção matricial (Fredlund \& Rahardjo, 1993)

Figura 2.4 - Curvas tensão x recalque de provas de carga sobre placa em solo não-saturado com diferentes sucções (Costa, 1999)

Figura 2.5 - Ocorrência de colapso em prova de carga realizada com inundação durante o ensaio (Cintra, 1998)

Figura 2.6 - Conceito básico de recalque adicional devido ao colapso da estrutura do solo (Jennings \& Knight, 1975)

Figura 2.7 - Processo de densificação do solo por compactação por injeção (Warner, 2004)

Figura 2.8 - Processo de fraturamento por injeção (Warner, 2004)

Figura 2.9 - Armação das estacas com macaco hidráulico plano e válvulas manchete para realização das injeções (Dapp et al., 2006)

Figura 2.10 - Bases injetadas de estacas extraídas após cura da calda (Dapp et al., 2006) .. 33

Figura 2.11 - Planta da zona de melhoramento com o uso de colunas injetadas (Ting \& Toh, 1985)

Figura 2.12 - Curva carga-recalque com ruptura nítida

Figura 2.13 - Ruptura física

Figura 2.14 - Critério de ruptura - NBR 6122/96

Figura 3.1 - Seção esquemática da geologia de pequena profundidade em São Carlos (Bortolucci, 1983).....

Tabela 3.1 - Valores de peso específico seco e umidade obtidos ao longo do perfil de coleta de blocos indeformados (Machado, 1998)

Figura 3.2 - Curvas granulométricas obtidas para as profundidades de 3,0, 5,0 e 8,0 m, em relação à superfície do terreno (Machado, 1998).

Tabela 3.2 - Frações granulométricas constituintes dos solos (Machado, 1998)

Figura 3.3 - Curva característica de sucção do solo para a profundidade de 2,0 m (Machado, 1998)

Figura 3.4 - Curva característica de sucção do solo para a profundidade de 5,0 m 
(Machado, 1998)

Figura 3.5 - Curva característica de sucção do solo para a profundidade de 8,0 m

(Machado, 1998)

Tabela 3.3 - Valores dos principais parâmetros utilizados no ajuste dos dados experimentais à equação proposta por Fredlund e Xing (1994) (Machado, 1998) 48

Figura 3.6 - Envoltória de resistência obtida para o solo saturado, profundidade de $2 \mathrm{~m}$ (Machado, 1998)

Figura 3.7 - Envoltória de resistência obtida para o solo saturado, profundidade de $5 \mathrm{~m}$ (Machado, 1998)

Figura 3.8 - Envoltória de resistência obtida para o solo saturado, profundidade de $8 \mathrm{~m}$ (Machado, 1998)

Figura 3.9 - Locação dos ensaios de campo (SPT e CPT) realizados no Campo Experimental de Fundações.

Figura 3.10 - Sondagens à Percussão da 3a Campanha (Santos, 2001) ....................................... 51

Figura 3.11 - Resultados de ensaios penetrométricos de SPT e CPTU (Machado, 1998) ............ 52

Figura 3.12 - Variação da sucção matricial e precipitação média diária ao longo do tempo, Moraes (2005)

Figura 3.13 - Curvas tensão x recalque de três ensaios consecutivos: um dinâmico entre dois estáticos (cava 9, terreno não inundado), Moraes (2005)

Figura 3.14 - Curvas tensão x recalque de três ensaios consecutivos: um dinâmico entre dois estáticos (cava 4, terreno não inundado), Moraes (2005)

Figura 3.15 - Curvas tensão x recalque de três ensaios consecutivos: um dinâmico entre dois estáticos (cava 7, terreno inundado), Moraes (2005)...

Figura 3.16 - Curvas tensão x recalque de três ensaios consecutivos: um dinâmico entre dois estáticos (cava 8, terreno inundado), Moraes (2005)....

Figura 3.17 - (a) Corte transversal do esquema tubo-placa na cava; (b) Tubo e placa posicionados na cava após uma sequência de golpes do martelo; (c) Detalhe da ligação tubo-placa

Tabela 3.4 - Características das provas de carga realizadas por Moraes (2005)

Figura 3.18 - Tubulão com base alargada, ensaiado em terreno previamente inundado (Carneiro, 1999).

Figura 3.19 - Tubulão com base alargada, ensaiado em terreno previamente inundado (Carneiro, 1999).

Figura 3.20 - Tubulão sem base alargada, ensaiado primeiramente em terreno não inundado (nível d'água igual a 7,0 m) e posteriormente com terreno previamente inundado (Carneiro, 1999)

Figura 3.21 - Tubulão sem base alargada, ensaiado em terreno não inundado, com nível d'água igual a 7,9 m no primeiro ensaio e 8,0 m no segundo (Carneiro, 1999) .. 
Figura 3.22 - Tubulão com base alargada, ensaiado primeiramente em terreno não inundado (nível d'água igual a 10,6 m) e posteriormente com terreno previamente inundado (Carneiro, 1999)

Figura 3.23 - Tubulão com base alargada. O primeiro ensaio foi interrompido devido à inundação acidental da cava (o nível d'água estava a 10,5 m). O segundo ensaio foi feito em terreno não inundado (com nível d'água igual a 7,2 m) e o terceiro com terreno

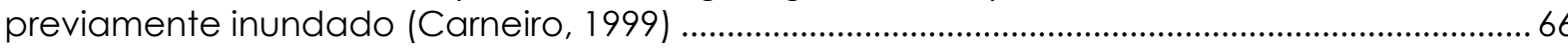

Tabela 3.6 - Características das provas de carga realizadas por Carneiro (1999) ....................66

Figura 3.24 - Curvas carga-recalque de três ensaios em tubulão a céu aberto, com solo não inundado (Benvenutti, 2001)

Figura 3.25 - Curvas carga-recalque de três ensaios em tubulão a céu aberto, com solo previamente inundado (Benvenutti, 2001)

Figura 3.26 - Estacas escavadas com diâmetros iguais a 0,35, 0,40 e 0,50 m; com comprimentos iguais a 10,60 m; ensaiadas à compressão com carregamento lento (Mantilla, 1992)

Figura 4.1 - Disposição dos cilindros e estacas executadas no Campo Experimental da USP/São Carlos

Figura 4.2 - Armação dos cilindros de concreto

Figura 4.3 - Concretagem

Figura 4.4 - Disposição dos tubos após a concretagem. Distâncias entre os tubos sem escala com medidas em cm. (a) cilindro 4; (b) cilindro 9; (c) cilindro 7 e (d) cilindro 8.

Figura 4.5 - Execução da injeção

Figura 4.6 - Sistema injetor .75

Figura 4.7 - Leitor de pressões 75

Figura 4.8 - Ordem de execução das injeções nos 5 furos de cada cilindro de concreto ....... 77

Tabela 4.1 - Consumo de cimento das bases injetadas .77

Tabela 4.2 - Pressões de injeção finais e máxima para cada cilindro de concreto .78

Figura 4.9 - Armação das estacas

Figura 4.10 - Armação das estacas com tubos de PVC 79

Figura 4.11 - Armação das estacas com tubo de PVC comum 80

Figura 4.12 - Armação das estacas posicionada na cava com PVC especial nas pontas ..... 80

Figura 4.13 - Execução da injeção .81

Figura 4.14 - Bomba de pistão .82

Figura 4.15 - Argamasseira e sistema injetor 


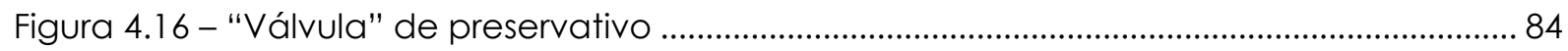

Tabela 4.3 - Consumo de cimento na injeção por estaca ................................................................ 84

Tabela 4.4 - Pressões de injeção finais e máximas atingidas durante as injeções para cada estaca.

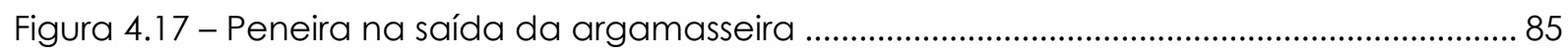

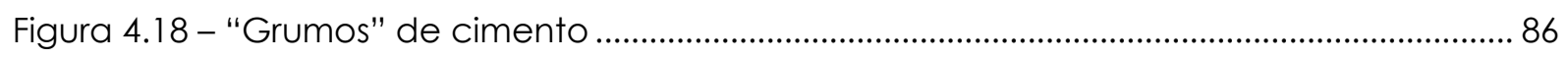

Figura 4.19 - Cilindro de concreto após remoção do solo lateral .................................................. 87

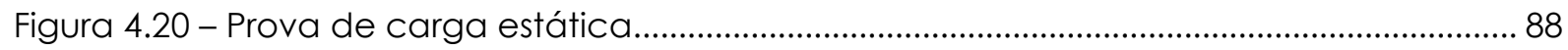

Figura 4.21 - Detalhe da prova de carga estática: cilindro de concreto com solo lateral removido

Figura 4.22 - Tensiômetros instalados na cava de controle. ........................................................... 90

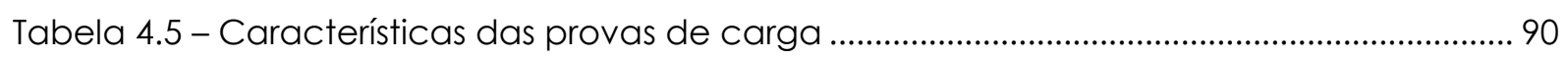

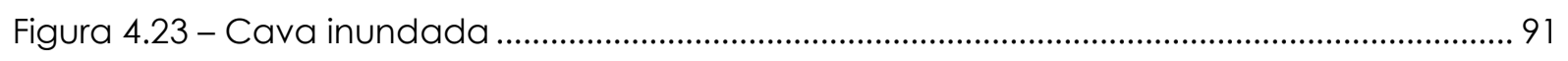

Tabela 4.6 - Características das provas de carga ....................................................................... 92

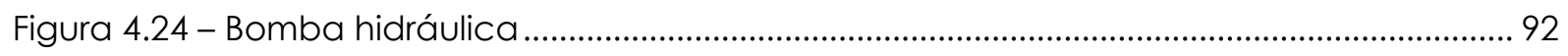

Figura 4.25 - Montagem da prova de carga estática ................................................................... 93

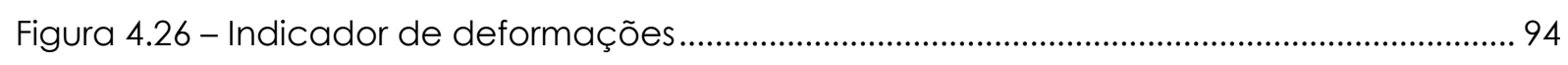

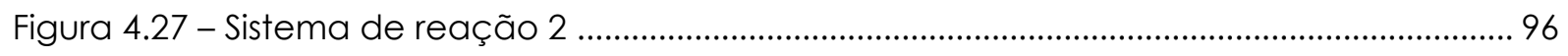

Figura 4.28 - Ligação dos tubulões com a viga de reação de $6 \mathrm{~m}$................................................. 96

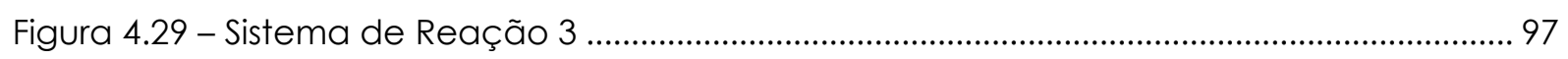

Figura 4.30 - Tentativa de extração com pórtico de reação ............................................................. 98

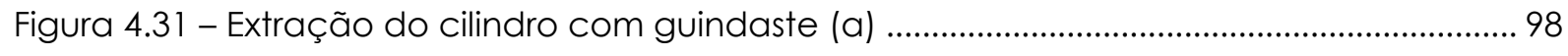

Figura 4.32 - Extração do cilindro com guindaste (b) .................................................................. 99

Figura 4.33 - Extração do cilindro com guindaste (c) .................................................................. 99

Tabela 5.1 - Volume de calda das bases injetadas...................................................................... 100

Figura 5.1 - Curva tensão x recalque (base injetada 4, terreno não inundado) ...................... 101

Figura 5.2 - Curva tensão x recalque (base injetada 9, terreno não inundado) ........................ 102

Figura 5.3 - Curva tensão x recalque (base injetada 7, terreno inundado) ............................... 103

Figura 5.4 - Curva tensão x recalque (base injetada 8, terreno inundado) ............................... 104

Tabela 5.2 - Características das estacas com base injetada....................................................... 105 
Figura 5.5 - Curva carga x recalque (estaca A, terreno inundado) ........................................... 106

Figura 5.6 - Curva carga x recalque (estaca B, terreno inundado) ............................................. 107

Figura 5.7 - Curva carga x recalque (estaca B, terreno não inundado) .................................... 108

Figura 5.8 - Curva carga x recalque (estaca C, terreno não inundado) .................................... 109

Figura 5.9 - Curva carga $x$ recalque (estaca D, terreno não inundado) ................................... 110

Figura 5.10 - Curva carga x recalque (estaca E, terreno não inundado) .................................. 111

Figura 5.11 - Curva carga $x$ recalque (estaca E, terreno inundado) ........................................112

Figura 5.12 - Valores de sucção matricial e níveis d'água medidos no campo .......................113

Figura 5.13 - Valores de precipitação média diária (Embrapa, 2010) ........................................ 113

Figura 6.1 - Provas de carga realizadas na cava 9 e projeção da prova de carga Q1 (em

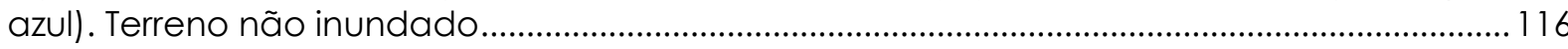

Figura 6.2 - Provas de carga realizadas na cava 4 e projeção da prova de carga Q1 (em azul). Terreno não inundado.

Figura 6.3 - Provas de carga realizadas na cava 7 e projeção da prova de carga QS1 (em azul). Terreno inundado...

Figura 6.4 - Provas de carga realizadas na cava 8 e projeção da prova de carga QS1 (em azul). Terreno inundado

Tabela 6.1 - Valores de capacidade de carga e sucção (cava 9, terreno não inundado) . 122 Tabela 6.2 - Valores de capacidade de carga e sucção (cava 4, terreno não inundado). 122 Tabela 6.3 - Valores de capacidade de carga e sucção (cava 7, terreno inundado) .......... 122 Tabela 6.4 - Valores de capacidade de carga e sucção (cava 8, terreno inundado) .......... 122 Figura 6.5 - Capacidade de carga de cada ensaio x recalque (cava não inundada) ......... 123 Figura 6.6 - Capacidade de carga de cada ensaio x recalque (cava não inundada) ......... 124 Figura 6.7 - Capacidade de carga de cada ensaio x recalque (cava inundada) ................ 125 Figura 6.8 - Capacidade de carga de cada ensaio x recalque (cava inundada) ................ 125

Figura 6.9 - Pedaços de calda no fundo da cava após extração do cilindro .......................... 126

Figura 6.10 - Calda e solo fofo após extração do cilindro .......................................................... 127

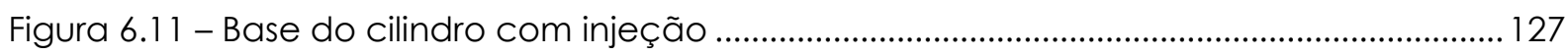

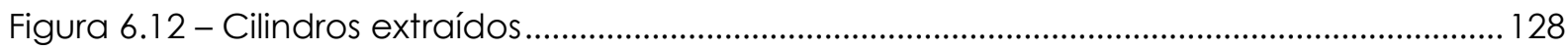

Figura 6.13 - Cilindros extraídos após lavagem com lavadora de alta pressão ........................ 128

Figura 6.14 - Aumento do diâmetro do cilindro promovido pela injeção de calda (a) ......... 129 
Figura 6.15 - Aumento do diâmetro do cilindro promovido pela injeção de calda (b) ......... 130

Figura 6.16 - Calda projetada para baixo

Figura 6.17 - Curvas carga $x$ recalque dos ensaios não inundados (NI) realizados nas estacas $B, C, D$ e E (EB, EC, ED e EE) com base injetada, tubulões com base alargada de 1,5 m (A) T5

e T6 (Carneiro, 1999) e tubulões sem base alargada (NA) T3 e T4 (Carneiro, 1999) 132

Figura 6.18 - Curvas carga $\times$ recalque dos ensaios inundados (I) realizados nas estacas $A, B$ e $\mathrm{E}$ (EA, EB e EE) com base injetada, tubulões com base de 1,5 m (A) T1, T2, T5 e T6 (Carneiro, 1999) e tubulão sem base alargada (NA) T3 (Carneiro, 1999) 133

Tabela 6.5 - Valores de capacidade de carga para os tubulões e estacas considerando um recalque igual a $60 \mathrm{~mm}$ - ensaios não inundados.

Tabela 6.6 - Valores de capacidade de carga para os tubulões e estacas considerando um recalque igual a $60 \mathrm{~mm}$ - ensaios inundados

Tabela 6.7 - Valores de capacidade de carga para estacas considerando um recalque igual a $10 \%$ do diâmetro - ensaios não inundados...

Figura 6.19 - Ensaios não inundados em estacas escavadas com 0,35, 0,40 e 0,50 m (Mantilla, 1992) e em tubulões com fuste de $0,60 \mathrm{~m}$ sem base alargada T3 e T4 (Carneiro, 1999) 137

Figura 6.20 - Ensaios não inundados em estacas escavadas com 0,35, 0,40 e 0,50 m (Mantilla, 1992); em tubulões com fuste de $0,60 \mathrm{~m}$ sem base alargada T3 e T4 (Carneiro, 1999) e nas estacas escavadas com base injetada. 138

Figura 6.21 - Precipitação média diária e nível d'água 139

Figura 6.22 - Precipitação média diária e sucção matricial. 140 


\section{INTRODUÇÃO}

A motivação inicial deste trabalho foi buscar uma alternativa aos tubulões a céu aberto, que constituem a solução bem mais empregada como fundações de edifícios residenciais construídos no interior do estado de São Paulo.

A predominância dos tubulões se explica pelo aspecto econômico e também porque nessa vasta região o solo é poroso e não saturado, apresentando facilidade para escavação e, ao mesmo tempo, exibindo estabilidade em cortes verticais.

A escavação manual dos fustes dos tubulões a céu aberto por muito tempo constituiu o procedimento usual. Mas aos poucos foi sendo introduzida a escavação mecanizada, por meio de trados, com evidentes ganhos de produtividade e de segurança nas condições de trabalho. Porém, as tentativas para alargamento da base também por procedimento mecanizado não obtiveram êxito. Por isso, atualmente os tubulões a céu aberto têm a abertura do fuste predominantemente mecanizada, mas continuam com a base alargada exclusivamente por escavação manual.

De algum tempo para cá, observa-se a tendência por um controle cada vez mais efetivo das normas de segurança de trabalho, por meio dos órgãos competentes, fazendo com que a produtividade deixe de ser tão vantajosa. Por outro lado, tem havido um número crescente de causas trabalhistas acionadas por poceiros, de tal modo que algumas empresas até deixaram de trabalhar com escavação manual de base de tubulões.

Assim, não é difícil prever que a solução de fundação por tubulões a céu aberto poderá entrar em declínio cada vez mais acentuado, no interior de São Paulo pelo menos. Por isso, julga-se de muito interesse a pesquisa de alternativas ao problema. Neste sentido, parece ser bem promissora a presente proposta do uso de injeções de calda de cimento sob a base de estacas escavadas, para melhorar as propriedades do solo sob a base, de forma a se obter estacas sem base alargada (escavadas mecanicamente tal como os fustes dos tubulões) com carga admissível maior que das estacas escavadas tradicionais. 
Esta pesquisa contempla um estudo experimental composto por três etapas. Na primeira, tem-se a construção de quatro bases injetadas com calda de cimento portland, executadas sob quatro cilindros de concreto com diâmetro igual a 0,80 m e comprimento igual a 1,80 m, para o domínio da técnica de injeção e adoção dos procedimentos e materiais mais adequados, complementada por provas de carga estática do tipo rápida, para verificação da capacidade de carga dos sistemas formados pelas bases injetadas e o solo.

Ainda na primeira etapa, os cilindros foram extraídos do solo para observação da distribuição e comportamento da calda e do maciço injetado.

Na segunda etapa, tem-se a execução de duas estacas escavadas, com base injetada, e posterior realização de provas de carga estática do tipo lenta e comparação com outras provas de carga similares realizadas em tubulões com e sem bases alargadas executados em pesquisas anteriores no campo experimental de fundações.

Na terceira etapa, três estacas de base injetada foram construídas, sendo que com o dobro do volume de calda para cada estaca em relação à segunda etapa. Também foram realizadas provas de carga lenta para comparação com tubulões e estacas da etapa anterior. As cinco estacas têm comprimento igual a $8 \mathrm{~m}$ e diâmetro de 0,60 m.

Como objetivos específicos da pesquisa, pode-se destacar a investigação dos seguintes aspectos:

- verificação e análise do processo de injeção por compactação, fraturamento do terreno ou permeação;

- desenvolvimento do método executivo das estacas de base injetada;

- $\quad$ análise e quantificação do comportamento do sistema solo melhoradoestaca em termos de resistência e deformabilidade;

- comparação do comportamento das estacas de base injetada com tubulões com base alargada e sem base alargada; 
- continuação do extenso programa de pesquisa realizado no Campo Experimental de Fundações da USP / São Carlos no tema da colapsibilidade, através da monitoração da sucção matricial atuante no solo e da realização de provas de carga com e sem inundação prévia do terreno. 


\section{REVISÃO BIBLIOGRÁFICA}

Nesse capítulo serão abordados quatro assuntos importantes para o entendimento da pesquisa realizada: tubulões a céu aberto e estacas escavadas, sucção matricial e colapsibilidade em solos não saturados, uso de injeções e prova de carga estática.

\subsection{TUBULÕES A CÉU ABERTO E ESTACAS ESCAVADAS}

A NBR 6122/96 define tubulão como sendo um elemento de fundação profunda, em que, pelo menos na sua etapa final, há descida de operário, e podem ser dotados de base alargada tronco-cônica. No manual de especificação de produtos e procedimentos da ABEF (2004), é determinado que, antes da concretagem, a base deva ser liberada pelo engenheiro supervisor ou consultor. Para este trabalho, será considerado tubulão o fuste escavado manual ou mecanicamente, com posterior limpeza do fundo e liberação por parte do engenheiro responsável, que pode ou não ter tido a base alargada. Nos artigos pesquisados foi feita uma adequação da nomenclatura para atender a essa definição, considerando-se estaca escavada quando não há descida e liberação da base.

Os tubulões a céu aberto são largamente utilizados como elementos estruturais isolados de fundação. Este fato se dá uma vez que apresentam, quando comparados a outros tipos de fundações, uma série de vantagens.

Conforme Heydenrych \& Beer (1975); Reese (1978); Broms et al. (1988) e Hartikainen \& Gambin (1994), o extenso emprego de tubulões pode ser atribuído a um número significante de fatores como:

-As escavações podem atravessar maciço de solos de elevada resistência, com pedras e matacões, sendo possível inclusive penetrar alguns tipos de rochas;

-Durante o processo de escavação pode-se classificar o solo retirado e compará-lo às condições iniciais do projeto para a caracterização do maciço de solos; 
- Os custos de mobilização e desmobilização são menores quando comparados à utilização de bate-estacas ou outros equipamentos de grande porte;

-O diâmetro e o comprimento dos tubulões podem ser modificados durante a escavação para compensar as estimativas iniciais das propriedades do maciço de solos;

-Pode-se, em geral, apoiar cada pilar em um fuste único, não sendo necessário o uso de bloco de coroamento;

- As etapas construtivas apresentam ruídos e vibrações de pouca intensidade, o que possui relevante importância para obras urbanas, próximas a edificações.

\section{PROCESSO EXECUTIVO}

Segundo Hartikainen \& Gambin (1994), o processo executivo de tubulões é governado principalmente pelas características do maciço de solos e das condições do canteiro de obras.

Em princípio, o procedimento de instalação do tubulão consiste em quatro etapas básicas: escavação, inspeção e liberação, colocação da armadura e concretagem (ABEF, 2004).

Reese (1978) e Hartikainen \& Gambin (1994) afirmam que existem vários métodos de execução, os quais diferem ligeiramente em detalhes como: a escavação pode ser realizada manualmente ou através de trados, perfuração por circulação rotativa ou técnicas vibratórias; o fuste ou poço da escavação pode ser protegido com contenção lateral ou não (ABEF, 2004), e a concretagem pode ser realizada por lançamento ou bombeamento do concreto. Nos casos em que não há descida de operário para limpeza do fundo da cava e liberação para concretagem por parte do engenheiro, como nas perfurações por circulação rotativa, tem-se uma estaca escavada com base alargada e não um tubulão, de acordo com a definição da ABEF (2004).

Segundo Liggitt (1992), a fim de possibilitar a execução de tubulões com base 
alargada, é necessário que o comprimento da escavação relativo ao fuste e ao alargamento da base deva continuar estável. De acordo com o autor, se faz também necessário que a base do tubulão esteja limpa para receber a concretagem.

INFLUÊNCIA DAS ETAPAS DE EXECUÇÃO NO COMPORTAMENTO DE TUBULÕES E ESTACAS

De acordo com Hartikainen \& Gambin (1994) o procedimento de instalação de tubulões envolve um número de fatores que podem causar danos ou defeitos ao longo do elemento estrutural isolado de fundações. Os autores ainda ressaltam que, a fim de prevenir a ocorrência de prejuízos, é necessário dar atenção quanto à qualidade das máquinas utilizadas, mão-de-obra e supervisão, com o objetivo de assegurar uma boa instalação e desempenho do tubulão.

Para Van Impe (1989), os efeitos resultantes no comportamento de estacas escavadas e tubulões, para um dado maciço de solos, são extremamente dependentes dos parâmetros de instalação, tal como do comprimento do fuste em relação ao diâmetro da base, forma e velocidade de escavação do maciço de solos, velocidade de lançamento e fluidez do concreto.

Defeitos causados pelo processo executivo incluem desagregação do solo, excesso de escavação para fora do diâmetro, cavidades em volta do fuste, má concretagem, etc. Esses fatores podem gerar problemas no comportamento de tubulões e estacas e provocar redução da capacidade de carga.

\section{ETAPA DE ESCAVAÇÃO}

De acordo com Manoliu et al. (1993), a fase de escavação representa a parte crítica do processo construtivo de um tubulão. Experiências obtidas em diversos casos foram apresentadas pelos autores no Romanian Code of Practice, dedicado a tubulões. 
Quando estacas escavadas ou tubulões são instalados em um dado maciço de solos, o estado de tensões ao redor do furo do fuste sofre uma mudança e tensões cisalhantes se desenvolvem ao longo do plano vertical.

De acordo com Ghionna (1993), o alívio de tensões e conseqüente descompressão do maciço de solos abaixo da base de tubulões, ambos associados ao processo de escavação, são responsáveis por um elevado deslocamento relativo necessário para a total mobilização da resistência de base última.

Teparaksa (1992) também enfatiza que o problema na construção de estacas escavadas é controlar os sedimentos provenientes do desmoronamento das paredes do furo e os efeitos de amolgamento na base e fuste das estacas, já que estes efeitos conduzirão a um excessivo recalque e baixa capacidade de carga. Ainda segundo o autor, tais problemas são maiores para estacas com base alargada, com diâmetro da base maiores que 1,0 m, quando comparados aos que têm menor dimensão.

Em estacas escavadas, nas quais não há limpeza do fundo da cava anteriormente à concretagem, Branco (2006) observa um acúmulo de $30 \mathrm{~cm}$ de material solto no fundo da cava para estacas com $25 \mathrm{~cm}$ de diâmetro e comprimento igual a $12 \mathrm{~m}$.

No trabalho, o comportamento de 6 estacas executadas da maneira tradicional e 6 com ponta de isopor foi semelhante, confirmando que o solo solto no fundo da escavação impede o contato direto da ponta da estaca com o solo natural, reduzindo a parcela de resistência referente à ponta.

Outras 3 estacas com geometria similar tiveram o fundo da escavação limpos com uma caçamba construída para esse fim. Segundo o autor, essas apresentaram uma melhor uniformidade com relação à distribuição das resistências, mas no geral tiveram comportamento semelhante às estacas tradicionais.

A Tabela 2.1 apresenta as resistências estáticas $\left(R_{e}\right)$ obtidas através de análises CAPWAP® das provas de carga dinâmica realizadas nas estacas. 
Tabela 2.1 - Resultado das análises CAPWAP® de estacas escavadas (Branco, 2006)

\begin{tabular}{|c|c|c|}
\hline Estaca & Tipo & $\operatorname{Re}(\mathrm{kN})$ \\
\hline A1 & tradicional & 369 \\
\hline A4 & tradicional & 438 \\
\hline B1 & tradicional & 414 \\
\hline C1 & tradicional & 377 \\
\hline C2 & tradicional & 414 \\
\hline A3 & ponta de isopor & 402 \\
\hline B8 & ponta limpa com caçamba & 446 \\
\hline B10 & ponta limpa com caçamba & 420 \\
\hline C8 & ponta limpa com caçamba & 321 \\
\hline
\end{tabular}

No caso específico de estacas escavadas, A NBR 6122/96 afirma que a resistência de atrito prevista na ruptura não pode ser inferior a $80 \%$ da carga admissível. Isso por que, além de existirem dúvidas sobre a limpeza de fundo, são necessários recalques elevados para a mobilização da carga de ponta, quando comparados com os recalques necessários para a mobilização do atrito lateral.

\section{ETAPA DE CONCRETAGEM}

Inúmeros dados estão disponíveis na literatura internacional enfatizando a relevância da fase de concretagem.

Segundo Broms et al. (1988) as estacas devem ser concretadas através de um processo contínuo do lançamento do concreto, sendo necessária a retirada de corpos de prova para a realização de ensaios de compressão, a fim de avaliar a qualidade do concreto. 
Para Van Impe (1989), o método de lançamento e a qualidade do concreto são de relevante importância, pois influenciam no comportamento das fundações profundas.

\section{OUTRAS TÉCNICAS DE EXECUÇÃO}

De acordo com Bottiau (1993), o lançamento do concreto sob elevada pressão melhora a fase de concretagem. Contudo, este processo deve ocorrer sob um controle adequado, verificando-se volume e pressão de lançamento do concreto. O autor afirma que o lançamento sob elevada pressão pode ser útil para melhorar o estado de tensões, no maciço de solos ao redor do elemento estrutural de fundação.

Miki (1979) apresenta um método de execução, denominado SSM - MAN, desenvolvido no Japão, pelo qual, a escavação do fuste da estaca é feita através da perfuração com circulação inversa e o alargamento da base, com o auxílio de um jato d'água. A Figura 2.1 ilustra as etapas do método SSM - MAN, sendo que cada estágio, de (1) ao (6) está descrito a seguir:

(1) a escavação é finalizada com jateamento d'água;

(2) o diâmetro do espaço escavado é medido horizontalmente com o auxílio de sensores rotatórios baseado no método de ondas supersônicas;

(3) sedimentos no fundo da base das estacas são removidos por jateamento d'água;

(4) \& (5) é realizada a instalação da armadura e, logo após, verificado se ainda existem sedimentos no fundo da escavação e sua remoção;

(6) lançamento do concreto no espaço escavado. 

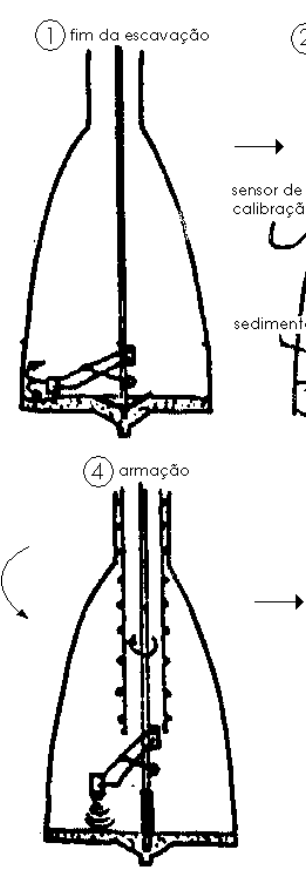

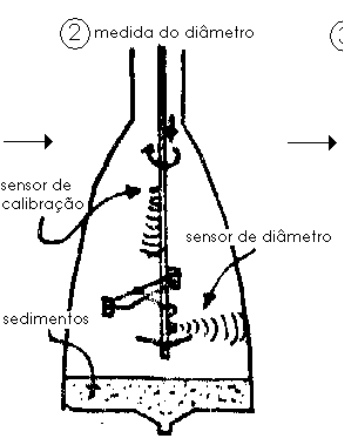

(5) verificação

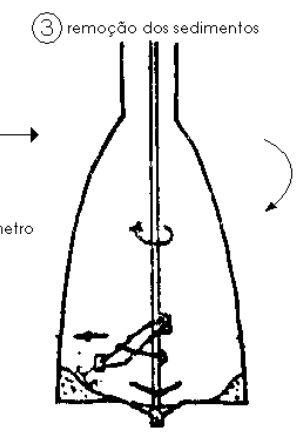

(6) concretagem
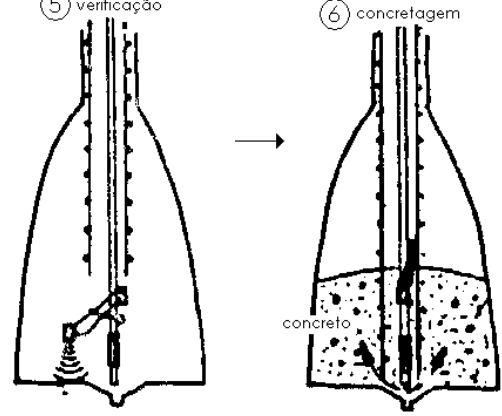

Figura 2.1 - Procedimentos Construtivos do Método SSM - MAN (Miki, 1979)

O sistema TFP, também desenvolvido no Japão, é bem semelhante. A escavação é igualmente feita com circulação de água e a base é alargada com o auxílio de uma broca especial (Figura 2.2). 


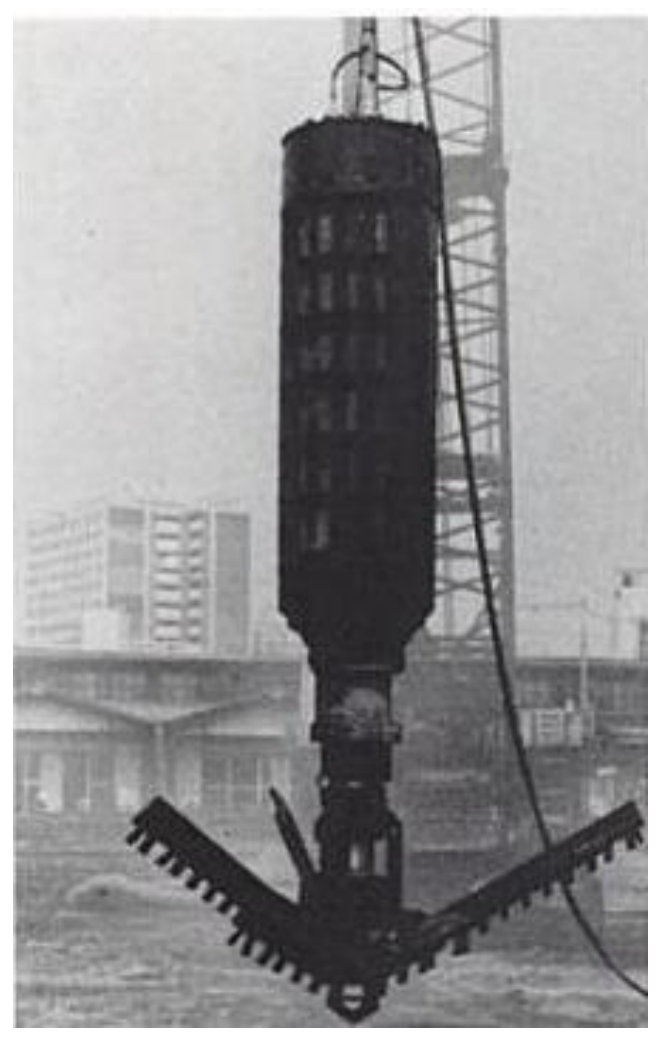

Figura 2.2 - Broca para alargamento da base de estacas escavadas (Mori \& Inamura, 1991)

Mori \& Inamura (1991) fazem um estudo comparativo entre duas estacas com mesma capacidade de carga e mesmo comprimento, sendo uma com diâmetro constante e igual a 1,9 $\mathrm{m}$ e a segunda com fuste de $1,5 \mathrm{~m}$ e base alargada de $2,0 \mathrm{~m}$. Os autores afirmam que há uma redução de quase $50 \%$ dos custos da fundação (construção e material) quando adotada a solução de bases alargadas.

Hartikainen \& Gambin (1994) apresentam outro possível método para aumentar a resistência de base de estacas escavadas e tubulões. Este método consiste em compactar o solo, abaixo da base da estaca. Os autores também mostram uma segunda possibilidade a fim de melhorar a capacidade de carga de estacas, que é o processo de injeção de calda de cimento nas paredes da escavação do fuste e da base. 
COMPORTAMENTO DE FUNDAÇÕES PROFUNDAS

Segundo Meyerhof (1988), o comportamento de estacas e tubulões depende, em larga escala, das condições do maciço de solos, sendo necessário para o dimensionamento e construção da estaca a realização de investigações de campo, a fim de determinar o estado de tensões iniciais in situ, e as características de resistência e deformabilidade do maciço.

Mello \& Aoki (1973) ressaltam a importância da avaliação de determinados parâmetros que interferem no comportamento das estacas escavadas e tubulões, os quais não são muito considerados no projeto tais como: o real valor dos parâmetros de resistência in situ, grandes variações quanto ao comportamento de tensão-deslocamento dependente do tipo de estaca e do tipo de execução e interpretação das provas de carga a respeito da distribuição de tensões, carga de ruptura e recalques.

\subsection{SUCÇÃO E COLAPSIBILIDADE}

De acordo com Gusmão Filho (1994) a maioria dos terrenos apresenta uma zona vadosa, que é a porção de solo acima do nível d'água. Na prática de engenharia, os solos não saturados estão presentes com muita freqüência nos terrenos sob os quais se projetam e executam fundações. Solos não saturados reagem diversamente a mudanças na pressão total e na sucção da água. O entendimento deste mecanismo permite a elaboração de projetos de fundação em solos não saturados mais racionais e mais econômicos.

Fredlund \& Rahardjo (1993) também afirmam que existem muitas situações em que o nível freático está bem abaixo da superfície e não é racional desenvolver um projeto baseado em um perfil saturado. Neste caso, medidas in situ da sucção abaixo das fundações de estruturas existentes na vizinhança podem ser muito úteis no desenvolvimento de projetos mais econômicos. 


\section{INFLUÊNCIA DA SUCÇÃO NA CAPACIDADE DE CARGA}

Em solos não saturados, um fator importante que deve ser considerado na análise da capacidade de carga é a sucção matricial. O papel relevante da sucção foi mostrado por Fredlund \& Rahardjo (1993), que quantificaram o aumento da capacidade de carga de fundações por sapatas corridas, de 0,5 e $1 \mathrm{~m}$ de largura assentes a 0,5 m de profundidade, com a sucção matricial (Figura 2.3), por meio da equação de Terzaghi (1943).

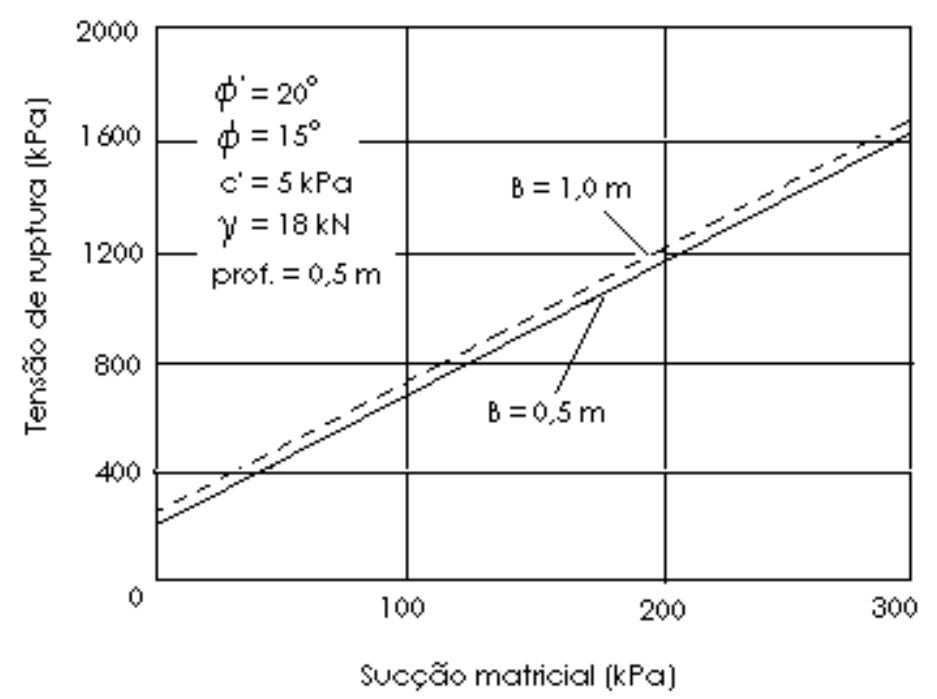

Figura 2.3 - Variação da capacidade de carga de sapatas corridas em função da sucção matricial (Fredlund \& Rahardjo, 1993)

Costa (1999) comprovou experimentalmente que a sucção matricial possui grande influência na capacidade de carga de fundações diretas. Por meio de provas de carga em placa, a 1,5 m de profundidade, realizadas no campo experimental de fundações da EESC/USP, o autor constatou que um pequeno aumento na sucção causa um substancial crescimento da capacidade de carga, como pode ser observado na Figura 2.4. 


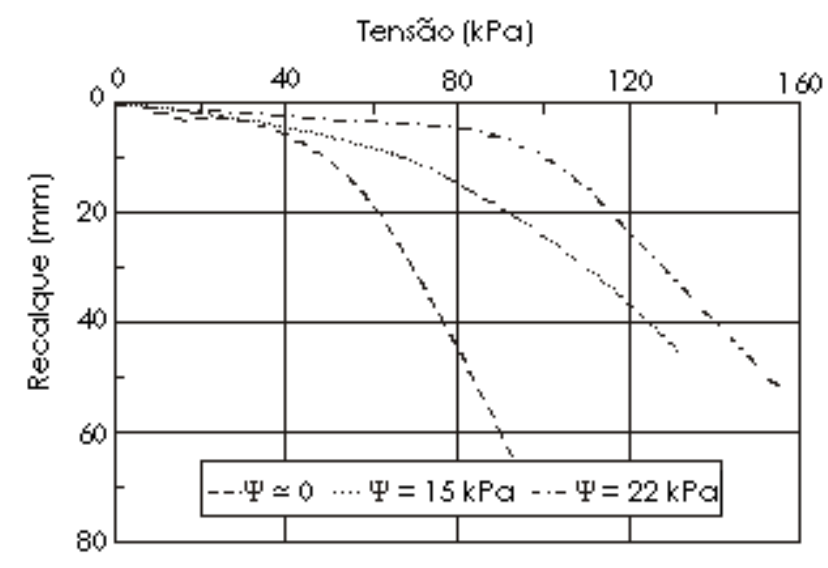

Figura 2.4 - Curvas tensão x recalque de provas de carga sobre placa em solo não-saturado com diferentes sucções (Costa, 1999)

A característica geral de um solo não saturado é que a sucção varia com a mudança de umidade, o que influencia o desempenho das fundações. Mudanças de sucção podem ser induzidas pela infiltração de água de chuva no solo, através do mecanismo de avanço da frente de umedecimento, a partir da superfície do terreno. Também são freqüentes as mudanças de umidade provocadas pela atividade antrópica, que se refletem na sucção do solo não saturado. É o caso de obras que desviam o fluxo de água subterrânea, elevam ou rebaixam a posição do nível piezométrico, provocam vazamento ou aquecimento do terreno.

De acordo com Fredlund \& Rahardjo (1993), o solo não saturado tem duas parcelas de coesão. A primeira componente é a coesão efetiva e a segunda é devida à sucção matricial. Fredlund \& Rahardjo (1993) afirmam que, com este conceito em mente, a teoria de capacidade de carga convencional é aplicável aos solos não saturados.

O aumento da sucção matricial contribui para dar resistência ao solo contra mudanças nas pressões aplicadas externamente pelos elementos de fundação. Isso porque o aumento de sucção resulta em aumento da coesão, e pouco afeta o ângulo de atrito (Fredlund \& Rahardjo, 1993). 
O aumento de resistência devido à sucção não continua indefinidamente. No caso de solo seco, a envoltória de ruptura coincide basicamente com a envoltória de ruptura saturada. O efeito da sucção sobre a resistência tem seu máximo em um grau de saturação intermediário (Gusmão Filho, 1994).

Segundo Campos et al. (1994), utiliza-se como rotina, no dimensionamento de contenções, a adoção de parâmetros obtidos ou estimados a partir de ensaios de cisalhamento realizados na condição de inundação dos corpos de prova. Tal postura leva freqüentemente à adoção de contenções de grande custo. Esses projetos têm sido questionados, pois na abertura de grandes cortes, mantidos sem contenção durante muito tempo, é pouco freqüente a ocorrência de problemas de instabilidade. Isto se deve ao fato que os taludes permanecem em condição de não saturação, tendo aumento de resistência devido à sucção.

\section{SOLOS COLAPSÍVEIS}

Segundo Cintra (1998), em certos tipos de solos não saturados, a inundação pode causar uma espécie de colapso da estrutura, caracterizado por um recalque suplementar, repentino e de grandes proporções. Este tipo de recalque é chamado colapso, sendo o solo classificado como colapsível.

O solo colapsível apresenta uma estrutura instável, porém com uma rigidez temporária mantida pela pressão de sucção e/ou cimentação. Para este solo entrar efetivamente em colapso é preciso que duas condições sejam satisfeitas: elevação do teor de umidade e atuação de um carregamento. Assim, se a carga atuante é suficientemente elevada, a adição de água ao solo colapsível causa redução na resistência, pois reduz ou dissipa a sucção e/ou enfraquece ou destrói a cimentação, podendo levar ao colapso do solo (Cintra, 1998).

Os solos colapsíveis apresentam um comportamento característico da curva tensão- 
deformação. Na Figura 2.5 observa-se ocorrência de colapso em uma prova de carga realizada com inundação do solo durante o ensaio.

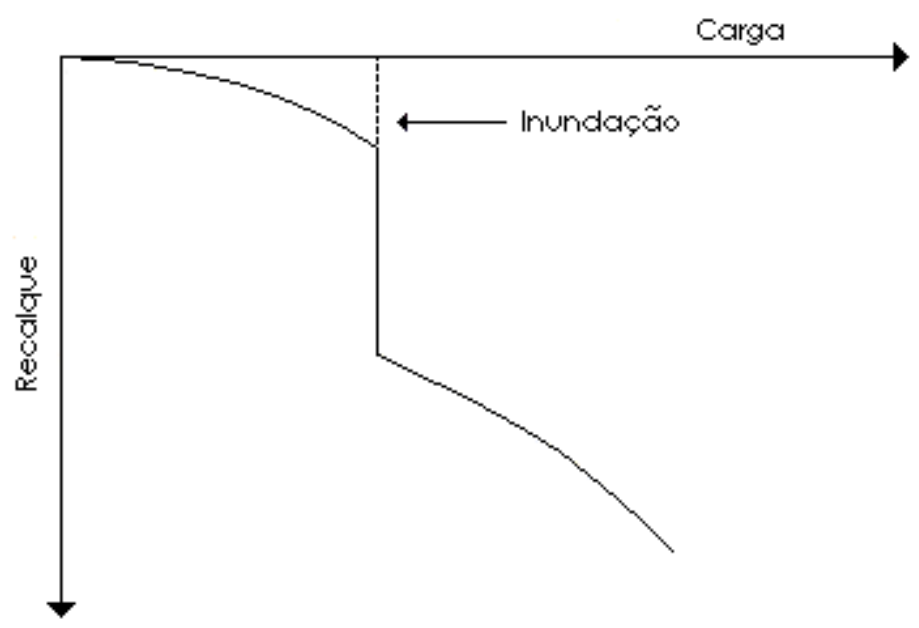

Figura 2.5 - Ocorrência de colapso em prova de carga realizada com inundação durante o ensaio (Cintra, 1998)

Em provas de carga com inundação prévia ao carregamento, o colapso não fica caracterizado por recalque repentino de grandes proporções, mas pelo aumento da deformabilidade e pela redução da capacidade de carga.

As características dos solos colapsíveis explicam o fato de fundações rasas, instaladas neste tipo de solo, apresentarem comportamento satisfatório durante algum tempo e com a presença de água passem a gerar problemas, em geral decorrentes de recalques diferenciais significativos (Figura 2.6). O aparecimento de água pode ser devido ao rompimento de tubulações da rede de água e esgoto, avanço da frente de umedecimento de águas pluviais, trincas em reservatórios subterrâneos, ascensão do lençol freático, etc. (Cintra, 1998). 

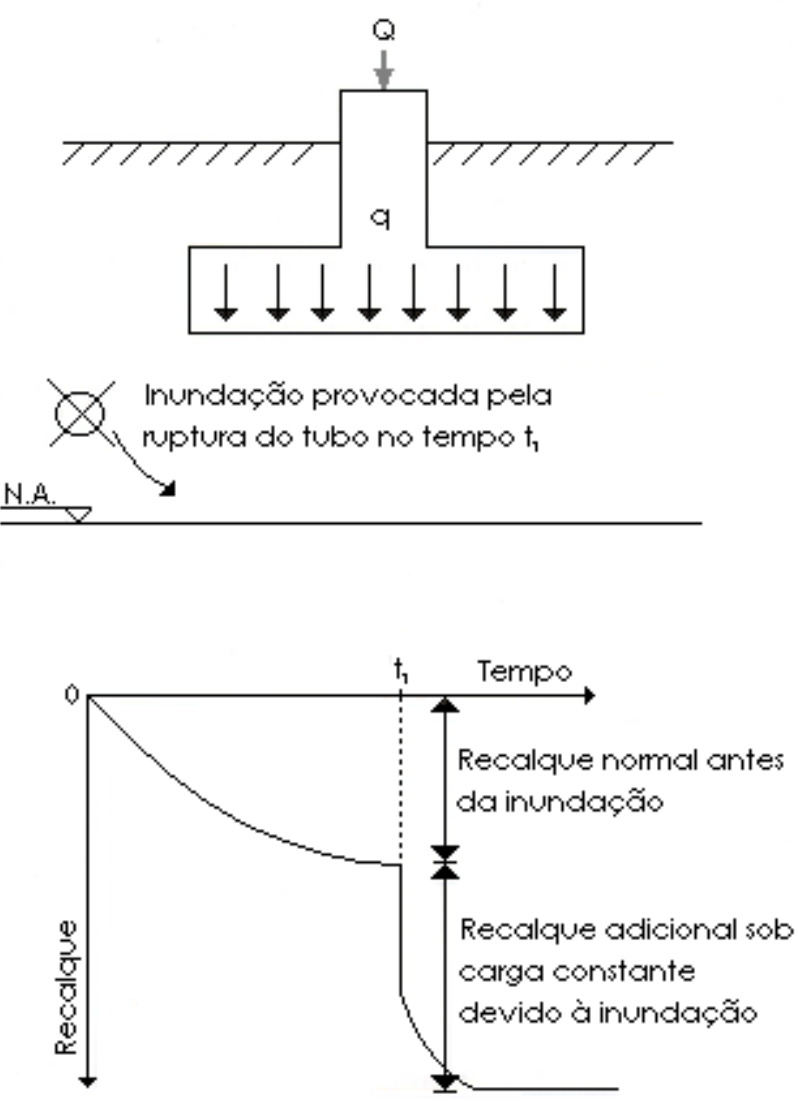

Figura 2.6 - Conceito básico de recalque adicional devido ao colapso da estrutura do solo (Jennings \& Knight, 1975)

\subsection{INJEÇÕES}

As injeções constituem um método através do qual caldas são inseridas sob pressão para preencher vazios, fissuras, falhas ou cavidades em solos ou formações de rochas de modo a melhorar suas propriedades, ou seja, diminuir a permeabilidade, aumentar a resistência ou reduzir a deformabilidade.

O criador da técnica de injeção foi o engenheiro civil francês Charles Berigny (Glossop, 1960), que em 1802 utilizou injeções de argila plástica para preencher um vazio formado pela erosão do solo com a passagem da água sob a fundação de uma barragem. O artigo de Glossop (1960) traz um histórico detalhado das injeções e suas aplicações desde o final do século 19. Os primeiros estudos sobre caldas de solo-cimento foram realizados na 
França, em 1937, com a finalidade de aplicá-las na consolidação das margens de um canal, em Argen. No Brasil, apenas em 1969, essa técnica foi empregada para recuperar uma pequena extensão do pavimento rígido da Via Anchieta, na Serra do Mar - SP.

Quando aplicado em solos, a injeção da calda pode modificar suas propriedades, através do preenchimento dos seus vazios ou pela compactação, promovendo a densificação dos solos. As técnicas mais usadas em solos são compactação, permeação, fratura hidráulica e mistura ou substituição.

Na injeção de compactação, o solo é compactado ou densificado, o que melhora significativamente sua capacidade de carga. Apesar dos grãos serem forçados a uma aproximação, há pouco ganho de coesão e de melhora de resistência ao cisalhamento. $\bigcirc$ método pode ser aplicado em uma grande variedade de solos arenosos e siltosos, e também os argilosos. Os solos coesos, quando saturados, precisam ter permeabilidade suficiente para permitir que a água seja expulsa dos vazios (Warner, 2004).

A compactação ocorre da seguinte forma: no interior de uma massa de solo, injetase calda com viscosidade elevada (slump entre 25 e $50 \mathrm{~mm}$ ), por meio de tubo de injeção que pode tanto ser instalado no terreno por cravação como perfuração. A calda atua como um macaco hidráulico radial e desloca fisicamente as partículas do solo (Figura 2.7). As pressões utilizadas são altas, geralmente entre 2.500 e $4.000 \mathrm{kPa}$, e provocam o processo de densificação da massa de solo ao redor da massa de calda expandida, melhorando assim a capacidade de carga e diminuindo a permeabilidade do solo circundante. 


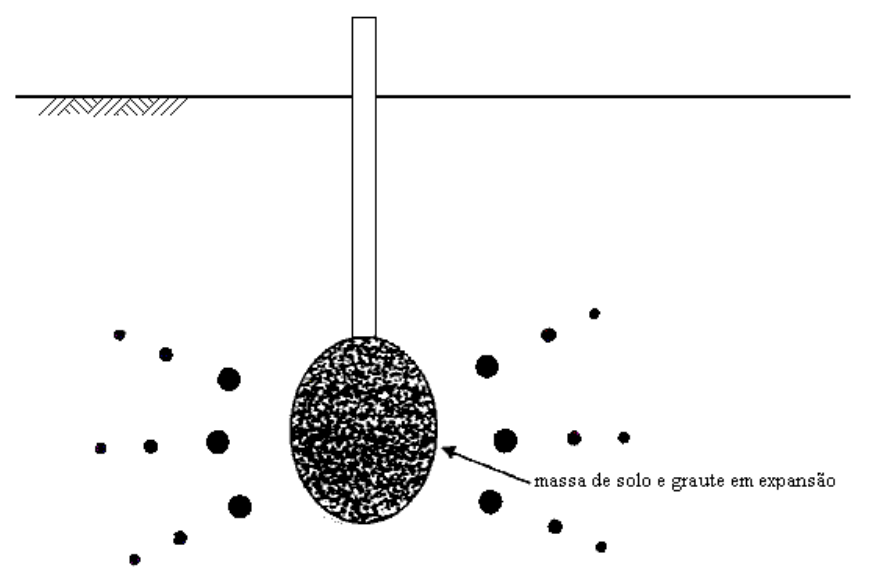

Figura 2.7 - Processo de densificação do solo por compactação por injeção (Warner, 2004)

A literatura internacional afirma que maior aplicação deste método é em reforços de fundações. Apesar de serem utilizadas altas pressões, a técnica apresenta poucos riscos de fraturamento hidráulico e outros danos. A massa injetada se comporta como um sólido, que "cresce" dentro do maciço (Warner, 2004 e Nonveiller, 1989).

No Brasil, Hachich et al. (2005) reportam a utilização de injeção de calda de cimento na estabilização e compensação dos recalques de uma fábrica construída em região de rocha calcária. Era esperado que se encontrassem grandes cavidades no maciço e o projeto previa a execução de injeções de caldas com slump de $20 \mathrm{~mm}$ sob pressão igual a $2.500 \mathrm{kPa}$. As cavidades existentes não eram tão grandes quanto o esperado e as especificações iniciais eram inviáveis para o equipamento disponível. O projeto foi então revisado e as pressões reduzidas para $1.500 \mathrm{kPa}$, e o slump foi aumentado para $50 \mathrm{~mm}$. Ainda assim, mesmo com a redução de pressão, o efeito conseguido não foi o desejável, pois a calda terminou por "empurrar" a camada de solo mais compressível e deflagrar um aumento considerável da taxa de recalque. A solução encontrada para este caso foi o uso de colunas de jet grouting. 
Este sistema difere substancialmente da compactação, pois é lançado um jato sob altíssima pressão, em média $30 \mathrm{MPa}$, que desestrutura o maciço e promove uma mistura entre o solo desagregado e a calda. Também pode ser executado de forma que a calda substitua todo o solo afetado. A resistência final da massa de solo reforçado depende da composição do solo original e da quantidade de calda utilizada.

Na injeção por permeação, a calda é injetada sob baixa pressão no interior do solo e preenche seus vazios, porem sem provocar alterações significantes na sua estrutura e no seu volume. O método aumenta tanto a capacidade de carga quanto a resistência ao cisalhamento, além de diminuir a permeabilidade do solo podendo chegar à estanqueidade. Seu uso é limitado aos solos mais permeáveis. Nesta técnica de injeção pode ser utilizado uma ampla gama de aglutinantes. A escolha de um determinado tipo de aglutinante é influenciada, principalmente pela permeabilidade do solo (geralmente utilizase a mistura água / cimento, em solos com condutividade hidráulica maior que $10^{-2} \mathrm{~cm} / \mathrm{s}$ ). Para solos com menor permeabilidade é possível utilização de resinas, e para condutividades hidráulicas inferiores a $10^{-6} \mathrm{~cm} / \mathrm{s}$ não é indicado o método de injeção por permeação.

Apesar de geralmente utilizar pressões mais baixas que a técnica de compactação, o método apresenta riscos de vazamento e fraturamento hidráulico, pois a calda injetada se comporta como um fluído.

O fraturamento também pode ser intencional. A calda é injetada no interior do solo sob alta pressão através de tubos com válvulas especiais, provocando o processo de fraturamento do solo. As fissuras resultantes são preenchidas com calda. O solo é modificado pela criação de uma massa reforçada pela rede de lentes de calda interconectadas, e também ocorre densificação (Figura 2.8).

Segundo Warner (2004), a injeção por fraturamento hidráulico também promove redução da permeabilidade. O nível de redução varia consideravelmente, dependendo da estrutura final da "rede de lentes". Warner (2004) também afirma que é praticamente 
impossível prever ou controlar a formação da estrutura de lentes e, consequentemente, a diminuição da permeabilidade. O método é adotado quando outras formas de injeção não são aplicáveis como, por exemplo, em formações argilosas com condutividades hidráulicas muito baixas.

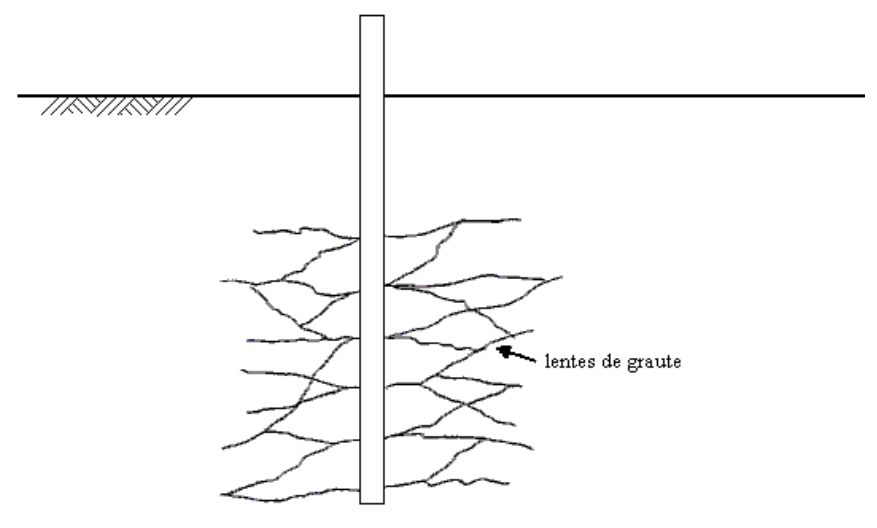

Figura 2.8 - Processo de fraturamento por injeção (Warner, 2004)

Para o entendimento do processo de fraturamento hidráulico de maciços terrosos recorreu-se aos primeiros estudos realizados em maciços rochosos. A técnica do fraturamento hidráulico em maciços rochosos vem sendo empregada há algumas décadas, principalmente na exploração petrolífera para estimular a produção dos poços. Hubbert \& Willis (1957) realizaram estudos teóricos e experimentais em corpos-de-prova de gelatina, na condição não drenada, ou seja, sem a ocorrência de fluxo do fluido na fratura durante o processo de fraturamento. Os autores verificaram que a fratura induzida tende a se apresentar perpendicularmente à direção da tensão principal menor.

É importante ressaltar que o fraturamento hidráulico em maciços, provocado por esforços de tração, se diferencia das rupturas por cisalhamento, que são obtidas pela aplicação de esforços cisalhantes.

Em condição não drenada, Kennard, 1970 (apud Barradas, 1985), realizou ensaios de 
infiltração em maciços terrosos e fez ainda a análise teórica sobre a iniciação do fraturamento. Foram observados dois tipos de mecanismo: a expansão do maciço e o seu fraturamento. O autor verificou que havia expansão do maciço terroso quando a pressão neutra no solo atinge um determinado valor de excesso de pressão. Nos ensaios em piezômetros, observou que, no trecho sob pressão, o maciço mostrou tendência em afastarse do tubo (piezômetro) e o espaço anelar foi ocupado pelo fluido injetado, no caso desse experimento, a água. Entretanto, quando o excesso da pressão neutra aplicada transmite tensões adicionais ao meio, podem ocorrer fraturas verticais ou horizontais no maciço, respectivamente, quando a tensão efetiva tangencial ou vertical se anula. Estudos de fraturamento hidráulico em ensaios de permeabilidade de campo também foram realizados por Bjerrum et al. (1972).

Em condições drenadas, ou seja, com movimento do fluido para o meio durante o fraturamento, Haimson \& Fairhurst (1967) admitiram tensões geradas pelo fluxo do fluido injetado no furo. Para estas condições, os autores desenvolveram análise do fraturamento vertical no maciço. Posteriormente, Barradas (1985) utilizou os mesmos dados e realizou estudo do desenvolvimento das fraturas horizontais.

Fraturamento hidráulico, compactação, permeação ou jet grouting: a escolha da técnica e dos componentes apropriados para a calda depende dos efeitos a serem alcançados e do material a ser injetado. As caldas são aplicadas sob pressão através de furos até que seja atingido o critério de saturação adotado, que pode ser preencher um volume pré-determinado de material ao redor do furo ou chegar à pressão de injeção máxima ou fluxo mínimo especificados.

No campo da mineração, Chen e Hu (2009) reportam o uso do software tridimensional baseado em elementos finitos COSFLOW para previsão do comportamento das injeções e dos maciços injetados para controle de recalques. As escolhas do método, das pressões de injeção e do volume de calda são feitas com o auxílio do software. 
PRESSÃO DE INJEÇÃO

A questão da pressão de injeção é um dos aspectos mais discutidos entre os técnicos, pois está relacionada diretamente com a absorção da calda. Em geral, quanto maior a pressão, maior será a penetração e, portanto, maior será a tomada de calda (Infanti Junior \& Nitta, 1978).

Sampaio (1988) observa variações de critérios estabelecidos nos diversos projetos de tratamentos de maciços rochosos por injeção de calda de cimento, realizados em fundações de barragens brasileiras. Foi constatado que os critérios mais difundidos no meio técnico, e consequentemente estabelecidos nos projetos, seguem a norma americana de baixas pressões, ou seja, pressão máxima de $23 \mathrm{kPa}$ por metro de profundidade do obturador. A norma européia, no entanto, permite pressões mais altas (100 kPa por metro de profundidade do obturador) e também já foi utilizada em projetos de barragens brasileiras (lyomasa \& Rodrigues, 2002).

Ainda sobre as pressões de injeção no tratamento de maciços rochosos, Duarte (1990), na tentativa de padronizar critérios e procedimentos nos trabalhos de injeção, experimentou utilizar nas obras brasileiras as recomendações do "Bureau of Reclamation" que sugerem a utilização do limite das pressões de injeção de até $58 \mathrm{kPa}$ por metro de profundidade. Ao final dos experimentos, o autor recomendou aplicar pressões mais elevadas para aumentar a eficiência das injeções, exceto nos locais onde existem trechos desfavoráveis à aplicação dessas pressões. Para o tratamento de maciço rochoso constituído por rocha de boa qualidade geomecânica, o autor apresentou as seguintes sugestões de critério para cálculo do limite máximo para a pressão de injeção em função dos traços das caldas de cimento:

- $40 \mathrm{kPa}$ por metro de profundidade para caldas de relação a:c = 1:1, em peso;

- $50 \mathrm{kPa}$ para as caldas 0,8:1,0;

- $60 \mathrm{kPa}$ para caldas $0,7: 1,0$ ou $0,6: 1,0$. 
Já para o caso de determinação das pressões de injeção em maciços terrosos os critérios utilizados são muito diferentes dos relatados anteriormente. Nos trabalhos de injeção em solos, o processo inicia-se pela ruptura do solo, enquanto que nos tratamentos de maciços rochosos há limites para a pressão, exatamente para evitar a ruptura da rocha.

Avaliações dos valores de pressões de ruptura dos solos foram feitas por Santos (1985), a partir dos dados obtidos no tratamento da fundação da barragem de terra de Balbina. Ao realizarem análise das pressões aplicadas, os autores verificaram que os valores ficaram entre $50 \mathrm{kPa}$ e $350 \mathrm{kPa}$ (valores por metro de profundidade). Além disso, realizaram a análise do comportamento da pressão aplicada desde a ruptura da bainha até a injeção da calda na fratura induzida. Os autores verificaram que, ao longo do tempo, a pressão crescia até atingir o valor máximo quando ocorria a ruptura da bainha e do maciço. Nos casos das bainhas que possuíam resistência mecânica superior ao do maciço terroso, a pressão aplicada decrescia e mantinha-se constante durante a injeção da calda. Quando a bainha apresentava resistência inferior ao do maciço de solo, ou quando a bainha não envolvia totalmente a válvula-manchete, não ocorria o decaimento da pressão aplicada após a ruptura do maciço. A pressão de injeção se mantinha constante após a ruptura e durante o preenchimento da fratura.

Outro aspecto relacionado com a pressão de injeção foi analisado por Oliveira \& Ferreira (1982), que estudaram a elevação da pressão de injeção em decorrência de sucessivas fases do tratamento. Os estudos desenvolvidos pelos autores foram fundamentados nos trabalhos de consolidação de depósito sedimentar da Bacia de São Paulo.

Outros estudos sobre elevações nas pressões de injeção também foram desenvolvidos por Guimarães Filho (1984) durante os trabalhos de tratamento com injeção de calda de cimento de um depósito aluvionar. O objetivo desse tratamento foi consolidar a camada de sedimento mole para abrigar parte de um túnel na cidade de São Paulo, da Companhia do Metropolitano - Metrô. O autor utilizou também informações extraídas do 
tratamento efetuado nas fundações de edifícios, na cidade de Santos, onde a consolidação do terreno foi conseguida por meio de campanhas sucessivas de injeções. 0 maciço terroso, produto de alteração da rocha do embasamento que recebeu as injeções, era constituído por areia fina argilosa, micácea, medianamente compacta, de cor cinza e amarela.

\section{INJEÇÕES EM SOLOS COLAPSÍVEIS}

Em solos colapsíveis, Abelev \& Askalonov (1957) descrevem um procedimento de melhoria do solo, para evitar o recalque de colapso através da aplicação de injeções. Trata-se do método de estabilização dos solos loéssicos por injeção de uma solução de silicato de sódio, empregado em 1949 na cidade de Zaporozhye, ex-URSS, na estabilização do loess de fundação sob chaminés de 80 e 120 m de altura (Cintra \& Aoki, 2009).

Esse método da silificação de solos loéssicos foi usado logo depois, de 1954 a 1956, como medida reparadora no Teatro Ópera de Odessa, afetado por recalques de colapso que se repetiam. Após o término dos trabalhos $\left(15.400 \mathrm{~m}^{3}\right.$ de solo estabilizado por meio de 2.250 furos de injeção), realizados sem interdição do teatro, os recalques cessaram. Nesse caso de Odessa, para verificar a eficácia do método, foram realizadas duas provas de carga em placa com área de $0,5 \mathrm{~m}^{2}$. O recalque do solo estabilizado, após inundação, foi igual a $3 \mathrm{~mm}$, enquanto o solo não-estabilizado recalcou $67 \mathrm{~mm}$, para a tensão aplicada de $250 \mathrm{kPa}$ (Cintra \& Aoki, 2009).

\section{INJEÇÕES EM ESTACAS E TUBULÕES}

Moretto (1975) apresenta uma técnica de injeção de estacas de grande diâmetro utilizando células de pré-carga. A célula utilizada é composta por uma câmara de metal presa à armação e conectada à superfície através de tubos por onde se pode passar água 
e calda de cimento. A placa inferior da câmara é perfurada e coberta por uma membrana de borracha também perfurada. Os furos da membrana são deslocados em relação ao da placa para que sirva como uma válvula, permitindo que a calda sob pressão saia para o solo e evitando o seu retorno. Abaixo da célula é colocada uma cesta aramada preenchida com brita para distribuir melhor a calda. $O$ procedimento, aplicado nas fundações de uma ponte sobre o rio Paraná, conferiu aumento da resistência lateral e melhorou o comportamento do solo sob a base.

Dapp et al. (2006) descrevem o uso de estacas escavadas com base injetada, em três casos de obras. As injeções sob as bases foram feitas através de macaco hidráulico plano ou válvulas manchete, com instrumentação composta por strain gages e medidor de pressão da calda. As pressões de injeção utilizadas eram altas (acima de $3.000 \mathrm{kPa}$ ) e suficientes para provocar um deslocamento vertical da estaca para cima. Os critérios de parada das injeções eram deslocamento da estaca, pressão de injeção e volume mínimo de calda a ser injetado.

O objetivo principal das injeções era mobilizar a capacidade de carga na ponta das estacas escavadas, melhorar o contato entre estaca e solo. Em estacas escavadas, a parcela de resistência relativa ao atrito lateral é totalmente mobilizada com deslocamentos entre $0,5 \%$ a $1 \%$ do diâmetro do fuste. Já para a completa mobilização da resistência de ponta são necessários deslocamentos muito maiores, em torno de $10 \%$ a $15 \%$ do diâmetro do fuste.

Na ponta de estacas escavadas mecanicamente ficam restos de material, solto e compressível, que provocam uma não uniformidade na transmissão do carregamento e podem inclusive diminuir a área da ponta ("bullet nose" - ponta em formato de bala).

A pressurização da ponta garante o contato entre estaca e solo e mobiliza a resistência de ponta, não sendo necessária a ocorrência de grandes recalques.

Dapp et al. (2006) comprovaram a melhoria de estacas escavadas com lama 
bentonítica com posterior injeção de calda sob a ponta através de provas de carga do tipo STATNAMIC $\circledast$. A Figura 2.9 mostra os arranjos colocados nas armaduras das estacas para realização das injeções e na Figura 2.10 veem-se as pontas de duas estacas extraídas do solo após cura do material injetado. É possível observar que o volume de material injetado é pequeno e que não há alargamento da base das estacas. O aumento da capacidade de carga se dá pela melhoria do contato entre solo e estaca provocado pela alta pressão da injeção de calda.

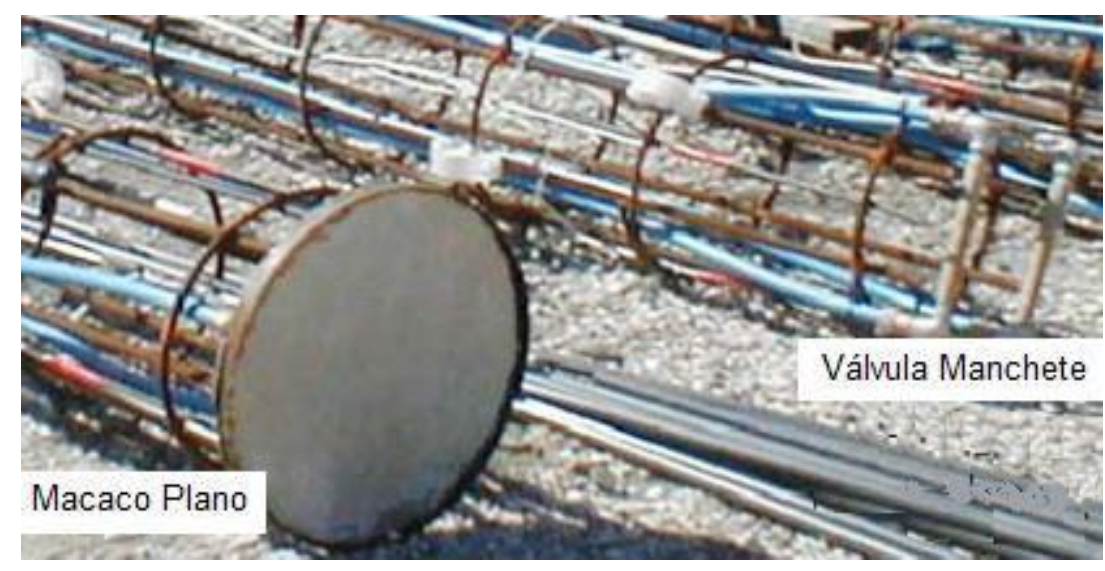

Figura 2.9 - Armação das estacas com macaco hidráulico plano e válvulas manchete para realização das injeções (Dapp et al., 2006)

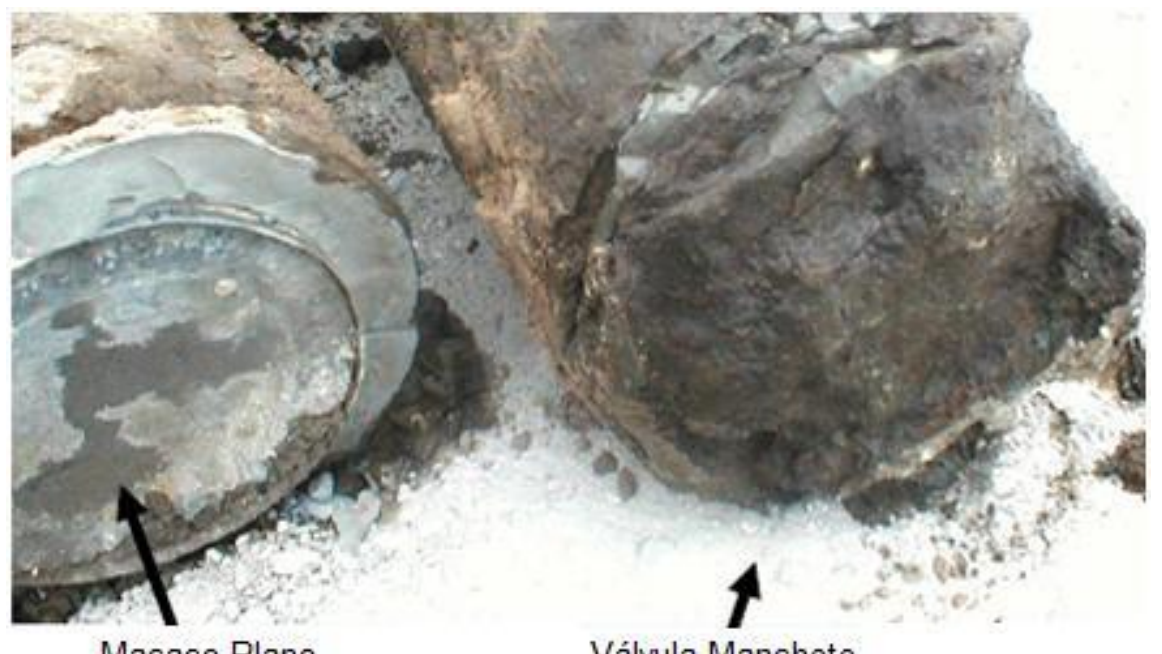

Macaco Plano

Válvula Manchete

Figura 2.10 - Bases injetadas de estacas extraídas após cura da calda (Dapp et al., 2006) 
Mullins at al. (2006) propõem um método para previsão da capacidade de carga das estacas com base injetada (de alta pressão e pouco volume de calda). Os autores correlacionaram a pressão de injeção com o aumento na capacidade de carga e desenvolveram um procedimento para projetos.

Wang at al. (2006) também apresentam um caso de obra em que foi utilizada a solução de estaca escavada com lama bentonítica com injeção sob a base. O aumento da capacidade de carga das estacas com injeção foi comprovado com a realização de três provas de carga estática em estacas injetadas e três em estacas escavadas com lama sem injeção.

No caso específico de tubulões, Ting \& Toh (1985) afirmam que o maciço de solos, na vizinhança do fuste de tubulões, foi melhorado através da construção de colunas de injeção de calda de cimento (Figura 2.11).

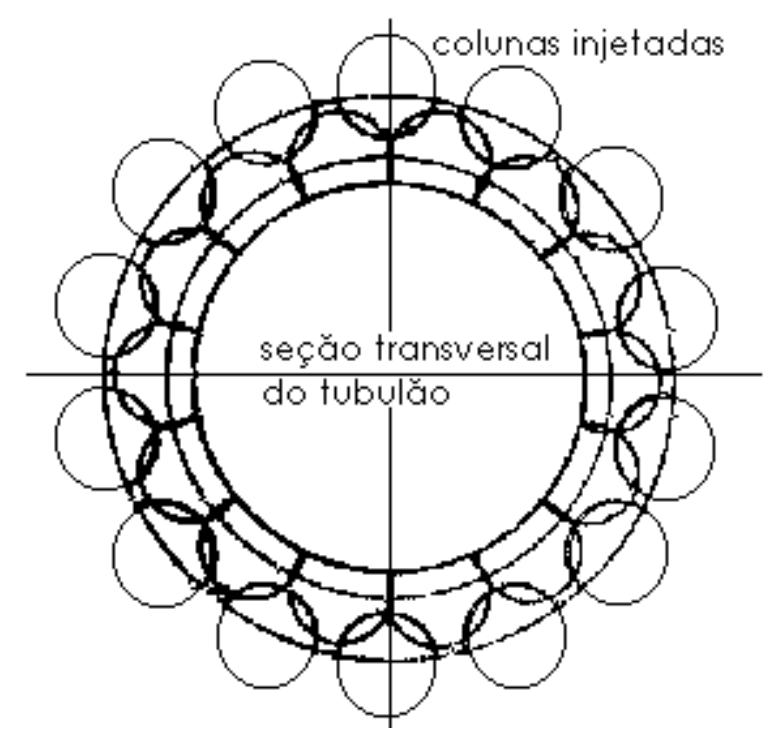

Figura 2.11 - Planta da zona de melhoramento com o uso de colunas injetadas (Ting \& Toh, 1985) 
A realização de provas de carga nos tubulões mostrou uma melhoria no comportamento do maciço de solos, em volta do fuste, com a utilização desta técnica de injeção. Adicionalmente, foi constatado que o tubulão construído na zona de coluna de injeção apresentou recalques menores que um tubulão similar construído pelo processo convencional, para as mesmas magnitudes de cargas e procedimentos de execução dos ensaios.

\section{TRAÇOS DE CALDAS}

A granulação da mistura de cimento e água é definida pelo tamanho dos grãos maiores contidos no cimento portland comum que, em geral, possuem dimensão da ordem de 200 micras. A ocorrência de grãos maiores pode limitar sua utilização nas injeções em rocha. Sabarly (1968) estudou a injetabilidade das caldas em fraturas de rochas e verificou que grânulos maiores de cimento impediam a penetração das caldas.

Tatamiya et al. (1971) realizaram ensaios em caldas de cimento utilizadas em tratamentos através de injeção em fraturas em rochas e verificaram que os maiores fatores água:cimento apresentavam maior penetração em fendas, porém eram pouco estáveis, tinham alto fator de sedimentação e baixa resistência mecânica após a cura. Para estabelecer o melhor traço das caldas de injeção, os autores realizaram ensaios com a finalidade de obter a curva Tempo de Escoamento X Fator de Sedimentação. A partir desta curva, os autores sugeriram que fossem determinadas as caldas mais injetáveis. Para a escolha da melhor calda é necessário observar a compatibilidade entre a facilidade de injeção e a resistência mecânica da calda após a cura.

A estabilidade das caldas de cimento pode ser obtida através do controle do volume de água em relação ao do cimento ou por meio da adição de materiais finos, como, por exemplo, a bentonita (Jones, 1963). O aumento do teor de água da mistura altera as características do fluido, facilitando sua penetração pelas fissuras, principalmente 
daquelas mais fechadas; porém, esta medida reduz a resistência das caldas endurecidas. Nos tratamentos efetuados em maciços rochosos, especialmente para fundações de barragens brasileiras, as caldas utilizadas têm traço, em peso, entre 1:1 até 0,4:1,0 (lyomasa e Rodrigues, 2002). No caso de injeção em solos, o traço típico é 0,5:1,0 (IPT, 1979).

É comum o emprego de produtos químicos, em proporções relativamente baixas de até $5 \%$ do cimento em peso, para melhorar a qualidade das caldas de água e cimento durante o processo de injeção. As substâncias tensoativas diminuem a tensão superficial das caldas e melhoram a curva de injetabilidade, enquanto que os aceleradores de pega são empregados quando se deseja obter resistências mecânicas relativamente altas, nas primeiras horas após a injeção. Outros produtos, como os expansores, servem para diminuir a sedimentação. A fluidez da calda pode ser aumentada com emprego de dispersante ou escória de alto-forno. Essa mistura facilita o bombeamento da calda durante a injeção, além de permitir maior penetração em fissuras. De forma oposta, as cinzas vulcânicas são utilizadas para diminuir a fluidez da calda e melhoram sua estabilidade (IPT, 1984).

O método de injeção em solos difere das técnicas utilizadas nos tratamentos das rochas sãs ou pouco alteradas, uma vez que é praticamente impossível fixar obturadores na parede do furo do maciço terroso. Assim, a injeção nesses maciços requer a instalação de tubos de PVC, fixados por meio de calda (bainha), contendo válvulas tipo manchete em intervalos previamente estabelecidos.

\subsection{PROVA DE CARGA ESTÁTICA}

A prova de carga estática é um ensaio de campo, que consiste na aplicação de esforços estáticos em estágios sucessivos. O objetivo do ensaio é obtenção de informações acerca da resistência e da deformabilidade, através da curva carga-recalque.

Há diversos tipos de montagem de provas de carga. Um sistema de reação 
adequado à direção, ao sentido e à intensidade das cargas de ensaio é necessário para permitir o apoio do macaco hidráulico ao aplicar o carregamento. De acordo com a NBR 12131/91, o sistema de reação para provas de carga à compressão pode ser:

a) plataforma carregada (cargueira), desde que:

1) a plataforma seja sustentada por cavaletes ou "fogueiras", projetadas de forma a garantir condições adequadas de segurança;

2) a plataforma seja carregada com material cuja massa total permita superar a carga máxima prevista para a prova em, ao menos, 20\%; e

3) a segurança do sistema seja verificada durante toda a realização da prova de carga;

b) estruturas fixadas ao terreno por meio de elementos tracionados, projetados e executados em número suficiente para que o conjunto permaneça estável sob as cargas máximas do ensaio.

Estes elementos tracionados podem ser:

1) conjunto de estacas definitivas, ou executadas apenas para atender à realização do ensaio, projetadas com capacidade de carga à tração, ao menos, $50 \%$ superior à máxima carga prevista para a prova. Por segurança, deve-se controlar o levantamento das estacas de reação durante todo o desenrolar da prova, através de deflectômetros ou leitura ótica;

2) conjunto de tirantes ancorados no terreno, obedecendo-se aos seguintes critérios:

- caso os tirantes sejam ensaiados antes da realização da prova de carga, admite-se um fator de segurança de 1,2.

- caso contrário, os mesmos devem ser projetados para suportar 1,5 vezes a máxima carga prevista para cada tirante;

c) a própria estrutura, devidamente verificada para todas as solicitações impostas pela prova de carga. 
TIPOS DE ENSAIO

Na execução da prova de carga, a estaca é carregada até a carga definida pelo projetista, atendendo aos requisitos de segurança da NBR 6122/96.

A critério do projetista, o ensaio pode ser realizado:

a) com carregamento rápido; ou

b) com carregamento lento; ou

c) com carregamento misto (lento seguido de rápido); ou

d) com carregamento cíclico, lento ou rápido.

Os deslocamentos correspondentes a estes quatro tipos de ensaios podem ser diferentes e sua interpretação deve considerar o tipo de carregamento empregado.

\section{Ensaio rápido - QML (Quick Maintained Load Test)}

Para o ensaio rápido, a NBR 12131/91 - "Estacas - Prova de Carga Estática" instrui que a carga aplicada em cada estágio não deve ser superior a 10\% da carga admissível prevista e deve permanecer por cinco minutos, fazendo-se leitura dos deslocamentos ao menos no início e no término de cada estágio de carga.

No caso de não ocorrer ruptura nítida ou deslocamento excessivo do solo, o ensaio deve ser conduzido até o dobro da carga admissível prevista. O descarregamento deve ser feito em quatro estágios, com leituras dos deslocamentos. A leitura final deve ser realizada dez minutos após o descarregamento total.

Fellenius (1975) recomenda que cada estágio de carga seja mantido por quinze minutos com leituras de deslocamentos a cada três minutos. Considerando um ensaio com 20 estágios de carregamento e quatro de descarregamento, o tempo total na proposição de Fellenius é de seis horas, o que viabiliza a realização do ensaio dentro de um dia. Com estágios de cinco minutos, como a norma sugere, o tempo total fica reduzido a duas horas, que representa pouco quando comparado ao tempo de montagem e desmontagem. 


\section{Ensaio lento - SML (Slow Maintained Load Test)}

No ensaio lento o carregamento também é executado em estágios iguais e sucessivos, nos quais a carga deve ser mantida até a estabilização dos deslocamentos e, no mínimo, por 30 minutos. A carga aplicada em cada estágio não deve ser superior a $20 \%$ da carga admissível prevista

A estabilização dos deslocamentos está atendida quando a diferença entre duas leituras consecutivas corresponder a, no máximo, 5\% do deslocamento havido no mesmo estágio (entre o deslocamento da estabilização do estágio anterior e o atual);

\section{Ensaio misto - MML (Mixed Maintained Load Test)}

No ensaio misto (MML), a primeira parte do ensaio é realizada tal como no ensaio lento até carga igual a 1,2 vezes a carga admissível prevista da estaca e a segunda como no ensaio rápido.

\section{Ensaio cíclico}

O ensaio cíclico é utilizado em estacas submetidas a esforços axiais de compressão e sua finalidade é permitir a separação das parcelas da resistência de ponta e de atrito lateral (Van Weele, 1957; Massad, 2002).

O carregamento é feito em ciclos de carga-descarga, com incrementos iguais e sucessivos.

INTERPRETAÇÃO DE PROVAS DE CARGA ESTÁTICA

A curva carga-recalque obtida em uma prova de carga estática pode apresentar três formas bem características.

Na primeira, a curva mostra que, para pequenos recalques, atinge-se um valor de 
carga que impõe recalques incessantes (Figura 2.12). Trata-se de uma ruptura nítida.

Na segunda forma, a curva é do tipo aberta, mas determina uma assíntota vertical, a qual caracteriza uma carga de ruptura correspondente a recalques praticamente infinitos (Figura 2.13). É a chamada ruptura física.

Em terceiro lugar, tem-se uma curva do tipo aberta, em que a carga cresce indefinidamente com a mobilização dos recalques, sem determinar a assíntota. Neste caso, para se obter um valor de carga de ruptura é exigida a aplicação de critérios arbitrários, e é denominada de ruptura convencional.

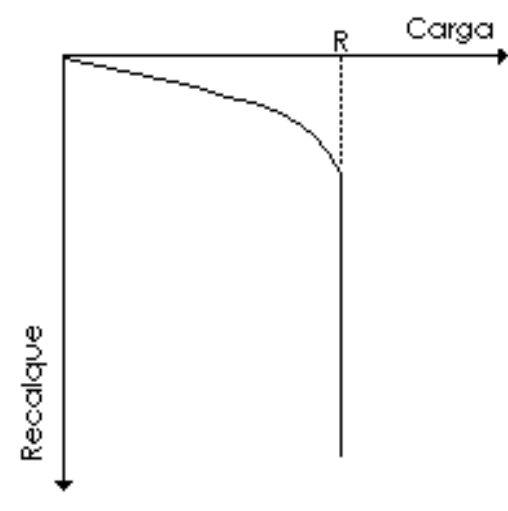

Figura 2.12 - Curva carga-recalque com ruptura nítida

A obtenção da carga de ruptura pode ser feita através do ajuste da curva cargarecalque com o auxílio de expressões matemáticas. Dentre eles estão os métodos de Chin (1970), Mazurkiewicz (1972) e Van der Veen (1953), sendo os dois últimos equivalentes. O método de Van der Veen é muito utilizado no Brasil e, além de definir a ruptura, permite extrapolar a curva. 


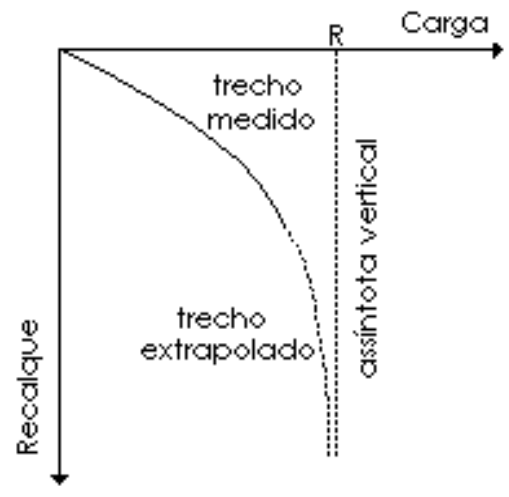

Figura 2.13 - Ruptura física

Outros critérios fixam a carga de ruptura em função de um deslocamento prédeterminado. No critério de Terzaghi (1943) ela corresponde a 10\% do diâmetro da estaca. Há ainda o critério da NBR 6122/96 (Figura 2.14) e de Davisson (1972), que sugere que o valor da carga limite Qlim seja estabelecido em função de um valor do recalque da cabeça da estaca que exceda a compressão elástica da estaca por um valor de $4 \mathrm{~mm}$ mais uma quantidade correspondente ao diâmetro da estaca, em milímetros, dividido por 120.

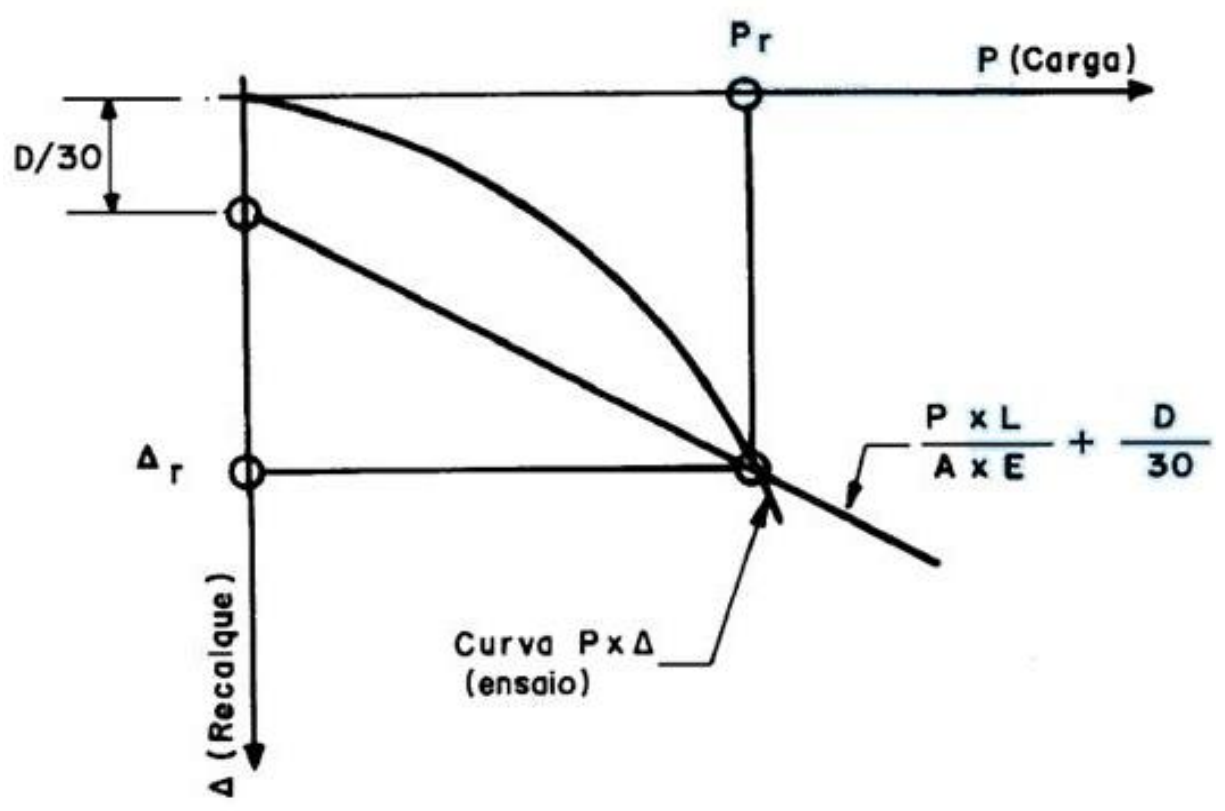

Figura 2.14 - Critério de ruptura - NBR 6122/96 
Para a NBR 6122/96 quando a estaca é carregada até apresentar um recalque considerável, e a curva carga-recalque não indica uma carga de ruptura, mas um crescimento contínuo do recalque com a carga, essa pode ser convencionada como aquela que corresponde, na curva carga x deslocamento, mostrada na Figura 2.14, ao recalque obtido pela equação 1, ou por outros métodos consagrados:

$$
\Delta_{r}=\frac{\mathrm{PxL}}{\operatorname{AxE}}+\frac{\mathrm{D}}{30}
$$

em que:
$\Delta_{r}=$ recalque de ruptura convencional
$\mathrm{P}_{\mathrm{r}}=$ carga de ruptura convencional
$L=$ comprimento da estaca
A = área da seção transversal da estaca
$\mathrm{E}=$ módulo de elasticidade do material da estaca
D = diâmetro do círculo circunscrito à estaca 


\section{CAMPO EXPERIMENTAL DE FUNDAÇÕES}

As provas de carga foram realizadas em estacas e bases injetadas executadas no campo experimental de fundações do Departamento de Geotecnia da USP/São Carlos.

A cidade de São Carlos fica cerca de 800 m acima do nível do mar, sobre as rochas do Grupo São Bento, compostas por arenitos da Formação Botucatu e Pirambóia e derrames de efusivas basálticas da Formação Serra Geral (Bortolucci, 1983).

O campo experimental está situado no extremo sul do campus da USP/São Carlos, em uma área cujo perfil geológico-geotécnico é considerado representativo da região centro-oeste do estado de São Paulo (Cintra et al., 1991). A Figura 3.1 mostra o perfil geológico de parte da cidade de São Carlos e a localização do campus da USP.

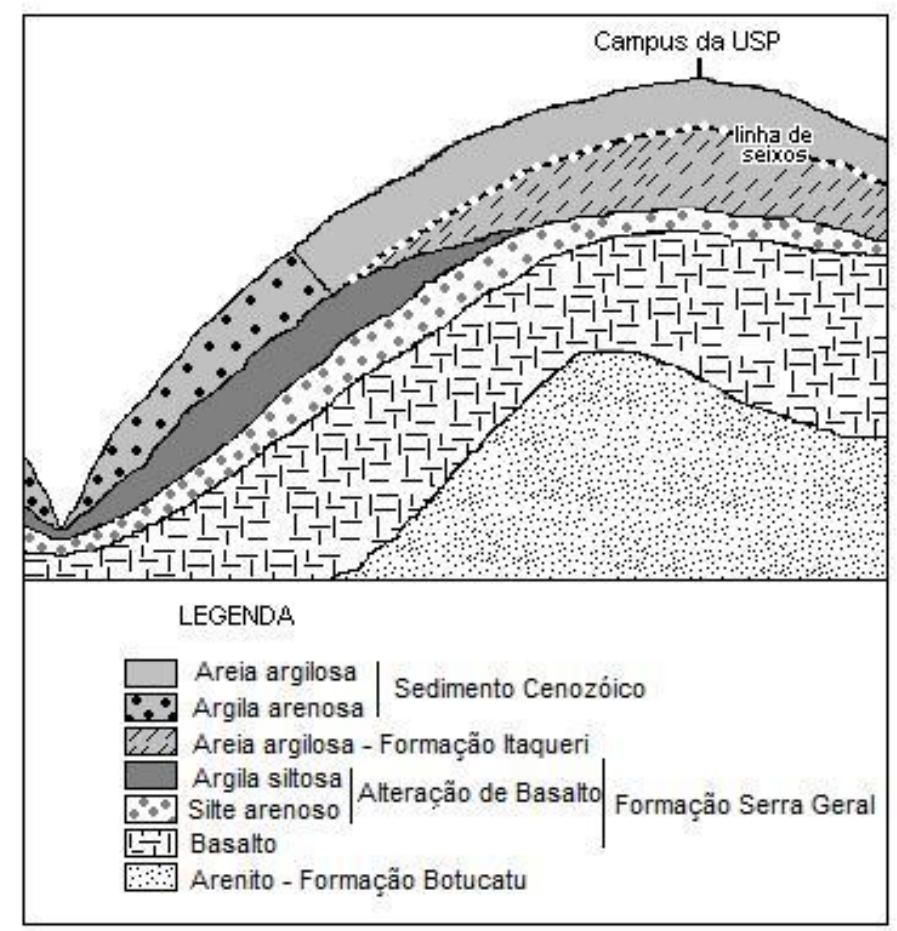

Figura 3.1 - Seção esquemática da geologia de pequena profundidade em São Carlos (Bortolucci, 1983) 
Na cidade de São Carlos encontram-se os arenitos da Formação Botucatu e basaltos da Formação Serra Geral. Sobre essas rochas ocorrem solos residuais das Formações Itaqueri e Serra Geral e, em seguida, cobrindo toda a região, aparecem os Sedimentos Cenozóicos.

Os Sedimentos Cenozóicos foram originados a partir do retrabalhamento dos materiais das Formações Serra Geral, Itaqueri e Botucatu. Esses sedimentos sofreram ação do intemperismo sob condições climáticas típicas de região tropical, o que provocou no material o processo de laterização. A camada é constituída por 35\% de argila e pelo menos $50 \%$ de areia média a fina. A espessura na região urbana é predominantemente entre 5 e 7 m, e é separada da camada de solo residual (Formação Itaqueri) por uma linha de seixos de quartzo e limonita.

Na região, tanto os solos residuais quanto os sedimentares se encontram no mesmo grupo, quando classificado pela Classificação Unificada. Os materiais apresentam, no entanto, comportamentos muito diferentes.

A área desse campo foi caracterizada geotecnicamente através de diversos ensaios laboratoriais (amostras deformadas e indeformadas retiradas de poços exploratórios) e in situ, dentre os quais uma campanha de cinco sondagens de simples reconhecimento (SPT) e cinco ensaios de penetração estática (CPT). Giachetti et al. (1993) apresentam um estudo dos resultados obtidos.

Machado (1998) realizou ensaios de laboratório em amostras indeformadas extraídas a cada metro, de um poço com diâmetro de 1,2 m, até uma profundidade de aproximadamente 10,0 m. Para todas as amostras realizaram-se ensaios de caracterização, ensaios de compressão confinada convencional saturada e com controle de sucção. Para as amostras coletadas nas profundidades de 2,0,5,0, e 8,0 m também se determinaram as curvas de retenção de umidade do solo e executaram-se ensaios triaxiais convencionais saturados e com sucção controlada.

A Tabela 3.1 mostra os valores de umidade e de peso específico seco obtidos, ao 
longo do perfil de coleta dos blocos indeformados. O valor do peso específico seco representa a média dos valores calculados a partir dos corpos de prova empregados nos ensaios de compressão confinada e triaxiais.

Tabela 3.1 - Valores de peso específico seco e umidade obtidos ao longo do perfil de coleta de blocos indeformados (Machado, 1998)

\begin{tabular}{|c|c|c|c|c|c|c|c|c|c|}
\hline Prof. $(\mathrm{m})$ & 1 & 2 & 3 & 4 & 5 & 6 & 7 & 8 & 9 \\
\hline $\mathrm{w}(\%)$ & 13,7 & 14,6 & 15,8 & 16,8 & 16,4 & 17,2 & 19,1 & 16,7 & 18,3 \\
\hline$\gamma_{\mathrm{d}}\left(\mathrm{kN} / \mathrm{m}^{3}\right)$ & 12,5 & 13,6 & 13,8 & 14,3 & 14,4 & 14,7 & 15,2 & 16,1 & 16,6 \\
\hline$\gamma\left(\mathrm{kN} / \mathrm{m}^{3}\right)$ & 14,2 & 15,6 & 16 & 16,7 & 14,8 & 17,1 & 18,1 & 18,8 & 19,6 \\
\hline $\mathrm{e}$ & 1,17 & 0,99 & 0,96 & 0,9 & 0,88 & 0,84 & 0,78 & 0,68 & 0,63 \\
\hline
\end{tabular}

A Figura 3.2 mostra as curvas granulométricas obtidas para as profundidades de 3,0, 5,0 e $8,0 \mathrm{~m}$. A Tabela 3.2 apresenta as frações granulométricas constituintes de cada profundidade. Observa-se que os resultados obtidos para as profundidades de 3,0 e 5,0 m são muito próximos, porém o solo da profundidade de 8,0 m apresenta um percentual de argila menor do que os anteriores.

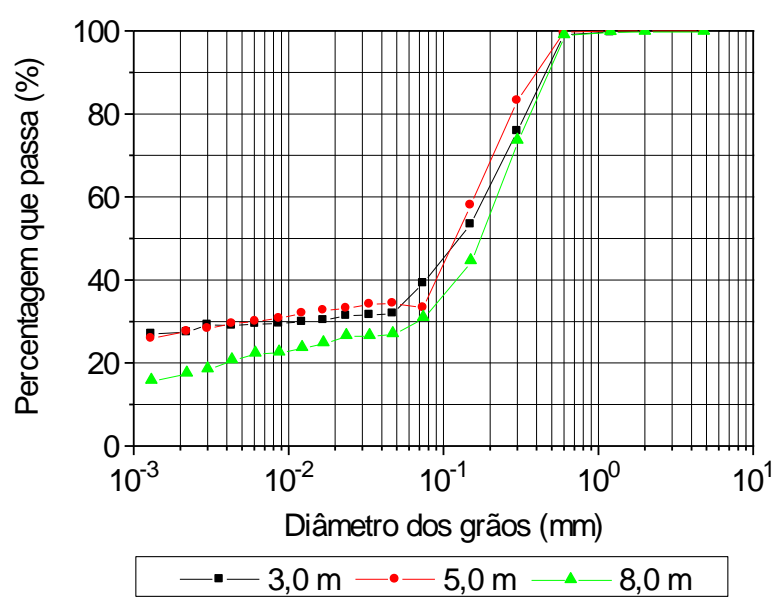

Figura 3.2 - Curvas granulométricas obtidas para as profundidades de 3,0, 5,0 e 8,0 m, em relação à superfície do terreno (Machado, 1998). 
Tabela 3.2 - Frações granulométricas constituintes dos solos (Machado, 1998)

\begin{tabular}{|c|c|c|c|}
\hline Prof. (m) & Areia (\%) & Silte (\%) & Argila (\%) \\
\hline 3 & 60,8 & 11,9 & 27,3 \\
\hline 5 & 66,7 & 5,9 & 27,4 \\
\hline 8 & 68,9 & 13,7 & 17,4 \\
\hline
\end{tabular}

As Figuras 3.3, 3.4 e 3.5 apresentam, respectivamente, as curvas características de sucção matricial obtidas para as profundidades de 2,0, 5,0 e 8,0 m, juntamente com o ajuste para cada curva utilizando a equação (1) proposta por Fredlund \& Xing (1994). Pode-se observar nestas figuras que os valores de entrada de ar em todas as profundidades ensaiadas são muito baixos, praticamente nulos. Isto ocorre porque o solo ensaiado apresenta estrutura com macro poros de grande diâmetro, visíveis a olho nu (Machado, 1998).

A Tabela 3.3 resume os valores adotados por Machado (1998) para os parâmetros apresentados na equação (2).

$\theta=\left[1-\frac{\ln \left(1+\frac{\psi}{\psi_{\mathrm{r}}}\right)}{\ln \left(1+\frac{1000.000}{\psi_{\mathrm{r}}}\right)}\right] \cdot \frac{\theta_{\mathrm{s}}}{\left\{\ln \left[\mathrm{e}+\left(\frac{\psi}{\mathrm{a}}\right)^{\mathrm{n}}\right]\right\}^{\mathrm{m}}}$

em que:

$\theta$ - umidade volumétrica;

$\theta_{s}$ - umidade volumétrica do solo saturado;

$\Psi_{r}$ - é a sucção correspondente ao teor de umidade residual, $\theta_{r}$.

e-base dos logaritmos neperianos;

a - é aproximadamente o valor de entrada de ar do solo;

n - é um parâmetro que controla a inclinação no ponto de inflexão da curva;

m - é um parâmetro relacionado ao teor de umidade residual. 


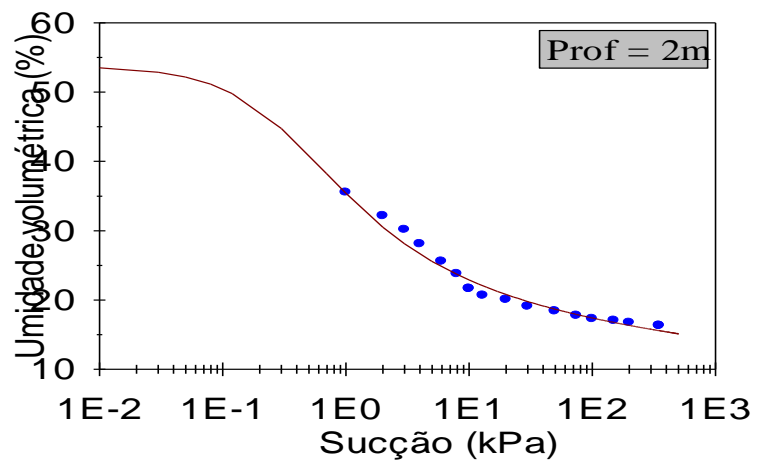

- Pontos experimenPaisntos ajustados

Figura 3.3 - Curva característica de sucção do solo para a profundidade de 2,0 m (Machado, 1998)

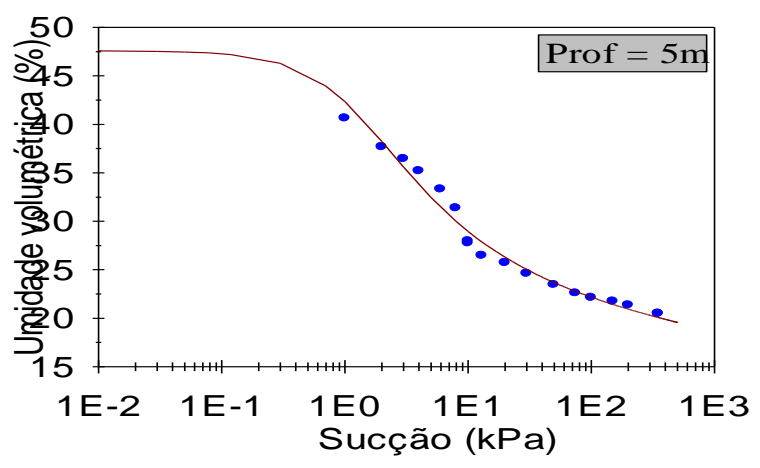

- Pontos experimenPámitos ajustados

Figura 3.4 - Curva característica de sucção do solo para a profundidade de 5,0 m (Machado, 1998)

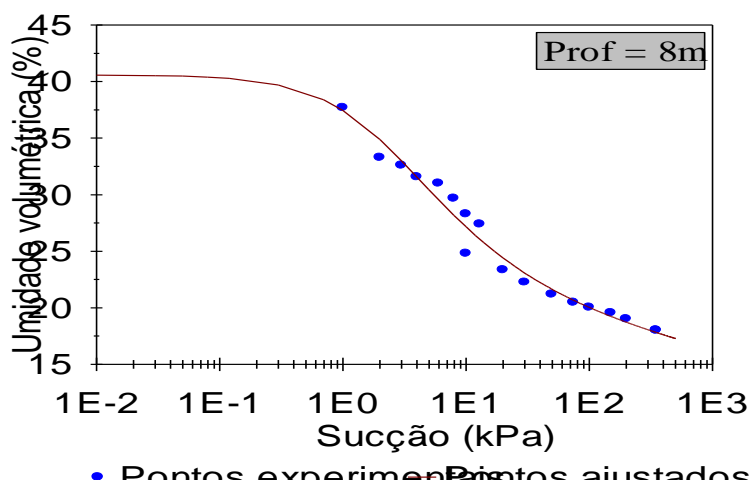

Figura 3.5 - Curva característica de sucção do solo para a profundidade de 8,0 m (Machado, 1998) 
Tabela 3.3 - Valores dos principais parâmetros utilizados no ajuste dos dados experimentais à equação proposta por Fredlund e Xing (1994) (Machado, 1998)

\begin{tabular}{|c|c|c|c|c|c|c|c|}
\hline Prof. $(\mathrm{m})$ & $\theta_{\text {sat }}(\%)$ & $\psi_{\mathrm{r}}(\mathrm{kPa})$ & $\mathrm{a}(\mathrm{kPa})$ & $\mathrm{n}$ & $\theta_{\mathrm{r}}(\%)$ & $\mathrm{m}$ & $\mathrm{R}^{2}$ \\
\hline 2 & 53,8 & 20000 & 0,25 & 1,2 & 10 & 0,57 & 0,984 \\
\hline 5 & 47,6 & 20000 & 0,95 & 1,4 & 13,6 & 0,41 & 0,984 \\
\hline 8 & 40,6 & 10000 & 1,5 & 1,2 & 12,4 & 0,43 & 0,977 \\
\hline
\end{tabular}

As Figuras 3.6, 3.7 e 3.8 apresentam as envoltórias de resistência para o solo saturado para as profundidades de 2, 5 e $8 \mathrm{~m}$, respectivamente. Também foram realizados ensaios triaxiais no solo não saturado com pressão de sucção imposta de 40, 80, 120 e 160 kPa para as três profundidades (Machado, 1998).

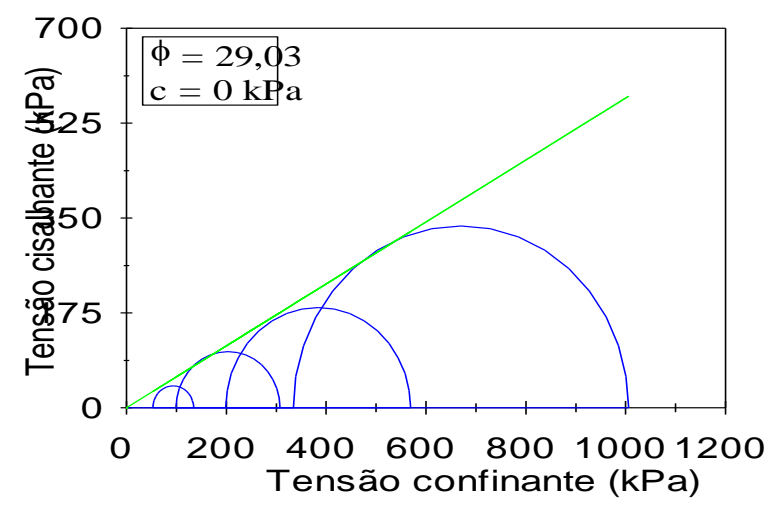

Figura 3.6 - Envoltória de resistência obtida para o solo saturado, profundidade de $2 \mathrm{~m}$ (Machado, 1998) 


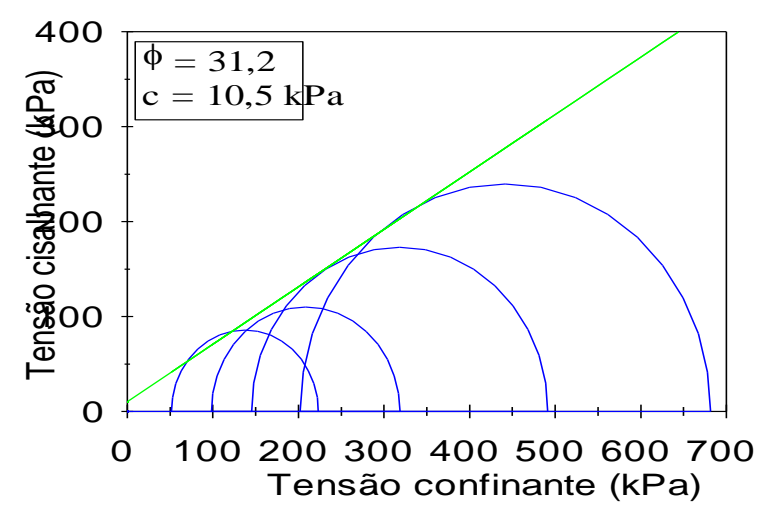

Figura 3.7 - Envoltória de resistência obtida para o solo saturado, profundidade de $5 \mathrm{~m}$ (Machado, 1998)

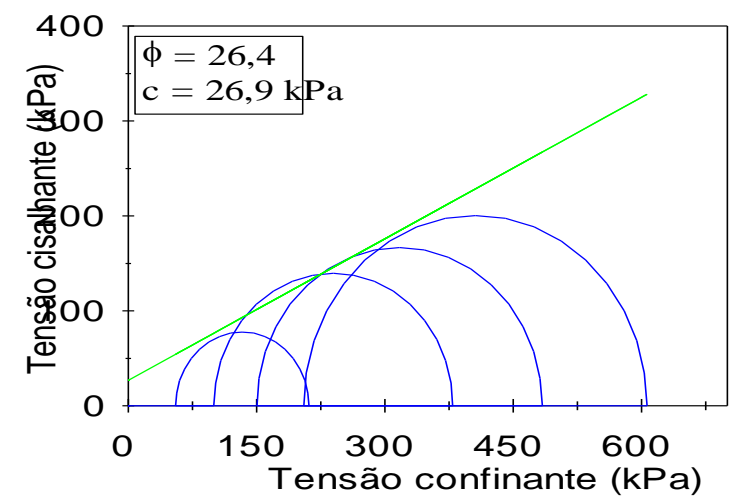

Figura 3.8 - Envoltória de resistência obtida para o solo saturado, profundidade de 8 m (Machado, 1998)

ENSAIOS IN SITU

Desde a implantação do Campo Experimental foram realizados diversos ensaios de campo, dentre os quais, 15 sondagens de simples reconhecimento com SPT, divididas em três campanhas de cinco furos, e dez ensaios de penetração estática (CPT) em duas campanhas com cinco furos cada uma. Na primeira campanha de CPT utilizou-se um cone mecânico e na segunda utilizou-se um cone elétrico com medida de pressão neutra. A Figura 3.9 mostra a locação destes ensaios no local da pesquisa. 


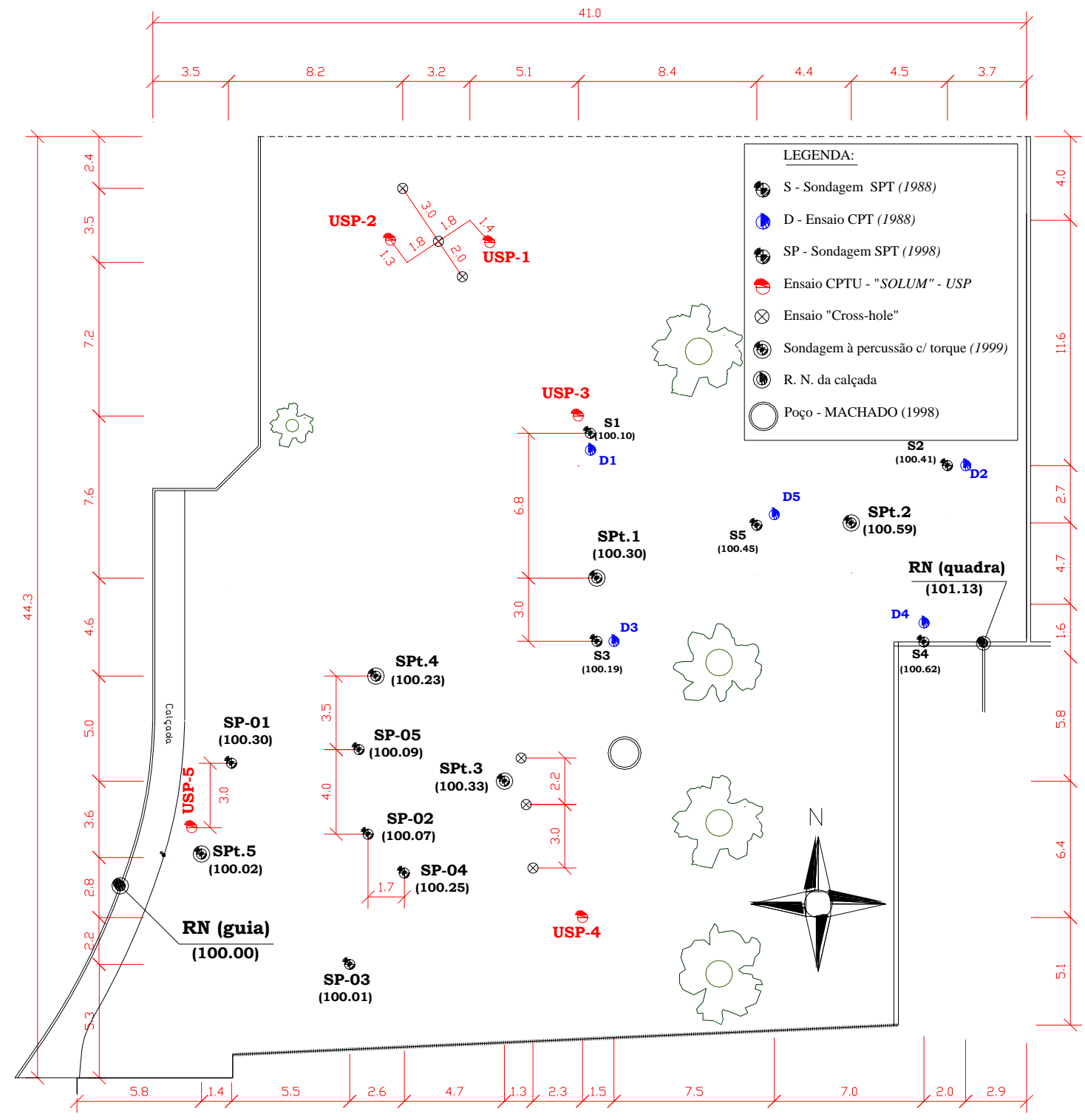

Figura 3.9 - Locação dos ensaios de campo (SPT e CPT) realizados no Campo Experimental de Fundações.

A Figura 3.10 mostra o perfil estratigráfico do maciço de solo no Campo Experimental, baseado nas sondagens SPT-T da terceira campanha. Nesta figura observa-se que o maciço de solo do local pode ser dividido em três camadas principais até o impenetrável. 


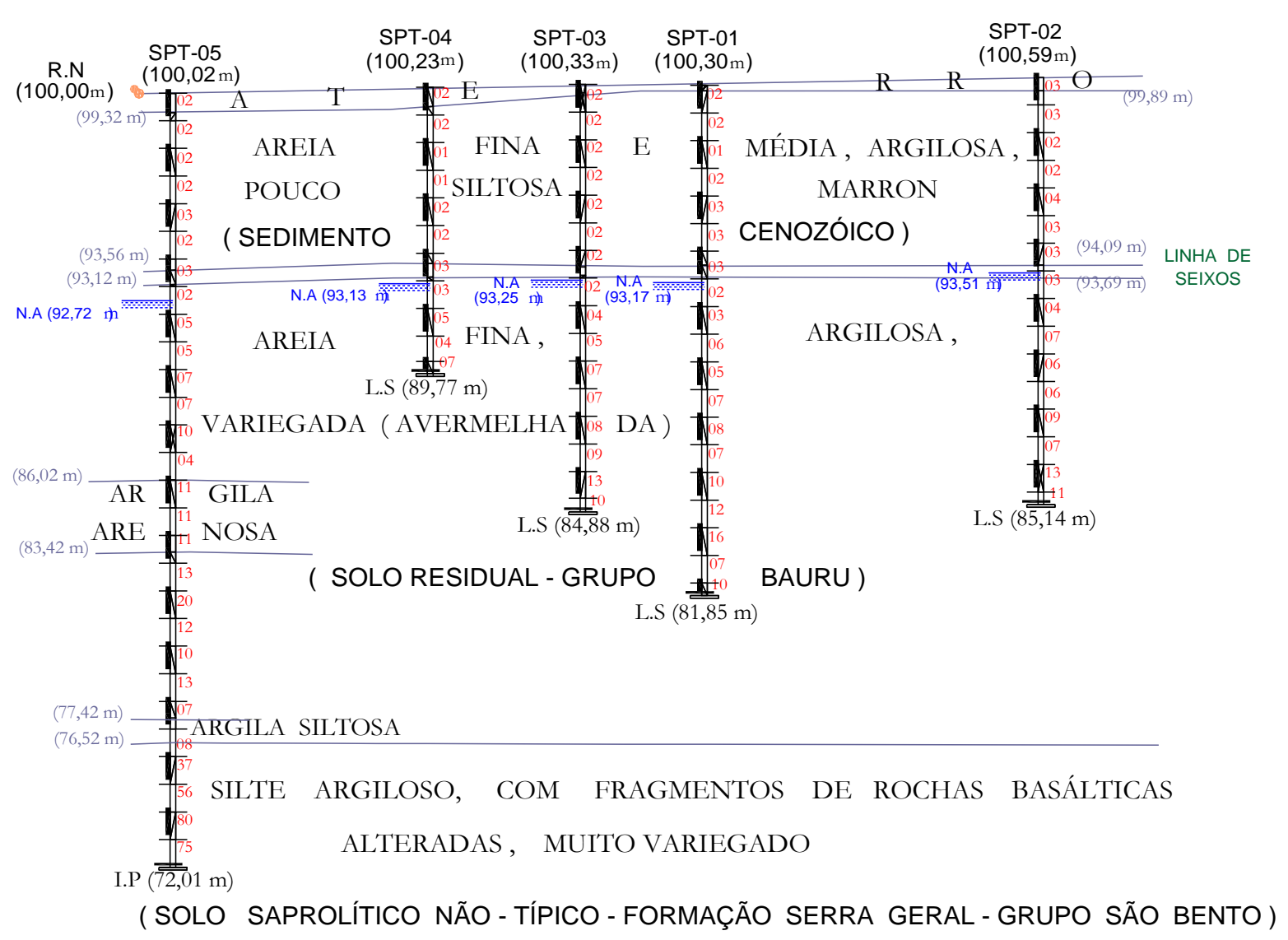

Figura 3.10 - Sondagens à Percussão da 3a Campanha (Santos, 2001)

A primeira camada é composta por uma areia fina argilosa marrom e fofa (Sedimento Cenozóico) que atinge aproximadamente $6,4 \mathrm{~m}$ de profundidade. Abaixo desta camada aparece uma linha de seixos com espessura variando de 0,1 a 0,5 m. A segunda camada é composta por uma areia fina argilosa marrom avermelhada, pouco a medianamente compacta, a qual atinge uma profundidade de cerca de 24,0 m (Solo Residual da Formação Itaqueri - Grupo Bauru). Finalmente, a terceira camada é composta por um silte argiloso variegado, compacto a muito compacto (Formação Serra Geral - Grupo São Bento).

A profundidade do nível do lençol freático varia entre 7,0 e 10,0 m, dependendo da época do ano. 
A Figura 3.11 apresenta os valores mínimos, médios e máximos dos resultados de ensaios penetrométricos de SPT e CPTU, ao longo do perfil de solo.

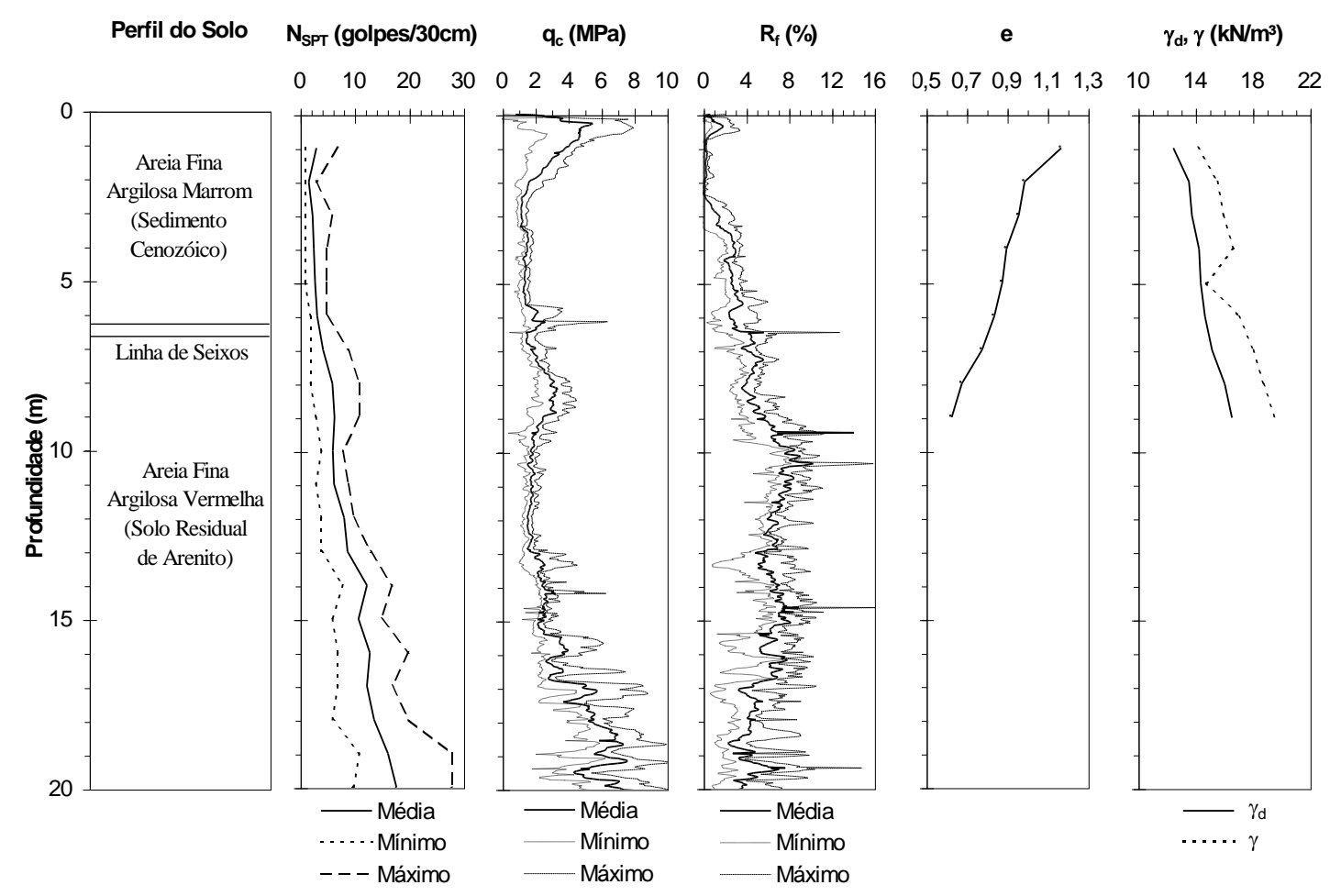

Figura 3.11 - Resultados de ensaios penetrométricos de SPT e CPTU (Machado, 1998)

Dentre as muitas pesquisas realizadas no campo, foram executadas provas de carga dinâmica em tubulões e placa, e provas de carga estática à compressão em tubulões e em estacas isoladas de diversos tipos e com diferentes geometrias, além de provas de carga estática em placas.

As pesquisas consideram tanto a condição de solo não-inundado (monitorando-se a sucção matricial no solo durante os ensaios), como a condição de solo inundado artificialmente, para a quantificação da redução de capacidade de carga da fundação por efeito da colapsibilidade do terreno, que é a característica marcante do solo superficial da região centro-oeste do Estado de São Paulo e de várias outras regiões brasileiras. 
PLACA DE 0,80 M

Foram realizadas 25 provas de carga estática e 9 provas de carga dinâmica em placa circular de $0,80 \mathrm{~m}$ de diâmetro. Esses ensaios foram executados com as placas assentes no terreno a 1,5 m, 4,0 m, e 6,0 $\mathrm{m}$ de profundidade, dentro dos projetos de pesquisa que incluíram os trabalhos de Costa (1999), Macacari (2001), Menegotto (2004) e Moraes (2005).

Quinze desses ensaios foram executados com inundação por um período mínimo de 24 horas, utilizando água potável proveniente da rede pública. Os demais ensaios foram realizados com o solo na condição não inundada, sendo a sucção medida através tensiômetros instalados ao redor da placa ou em cava de controle.

As cavas destinadas à realização das provas de carga foram escavadas manualmente com diâmetro igual a $0,90 \mathrm{~m}$, resultando em uma folga de aproximadamente $5,0 \mathrm{~cm}$ em volta da placa. Esta folga permitia instalação de tensiômetros e um melhor posicionamento da placa de ensaio em relação à viga de reação, além de contribuir com a infiltração da água no solo nos ensaios inundados. Na Figura 3.12 encontram-se os resultados da tensiometria, juntamente com dados de chuva fornecidos pela Embrapa Pecuária Sudeste (Fazenda Canchim, São Carlos-SP). As setas indicam os dias em que foram realizados ensaios em terreno não inundado (Moraes, 2005). 


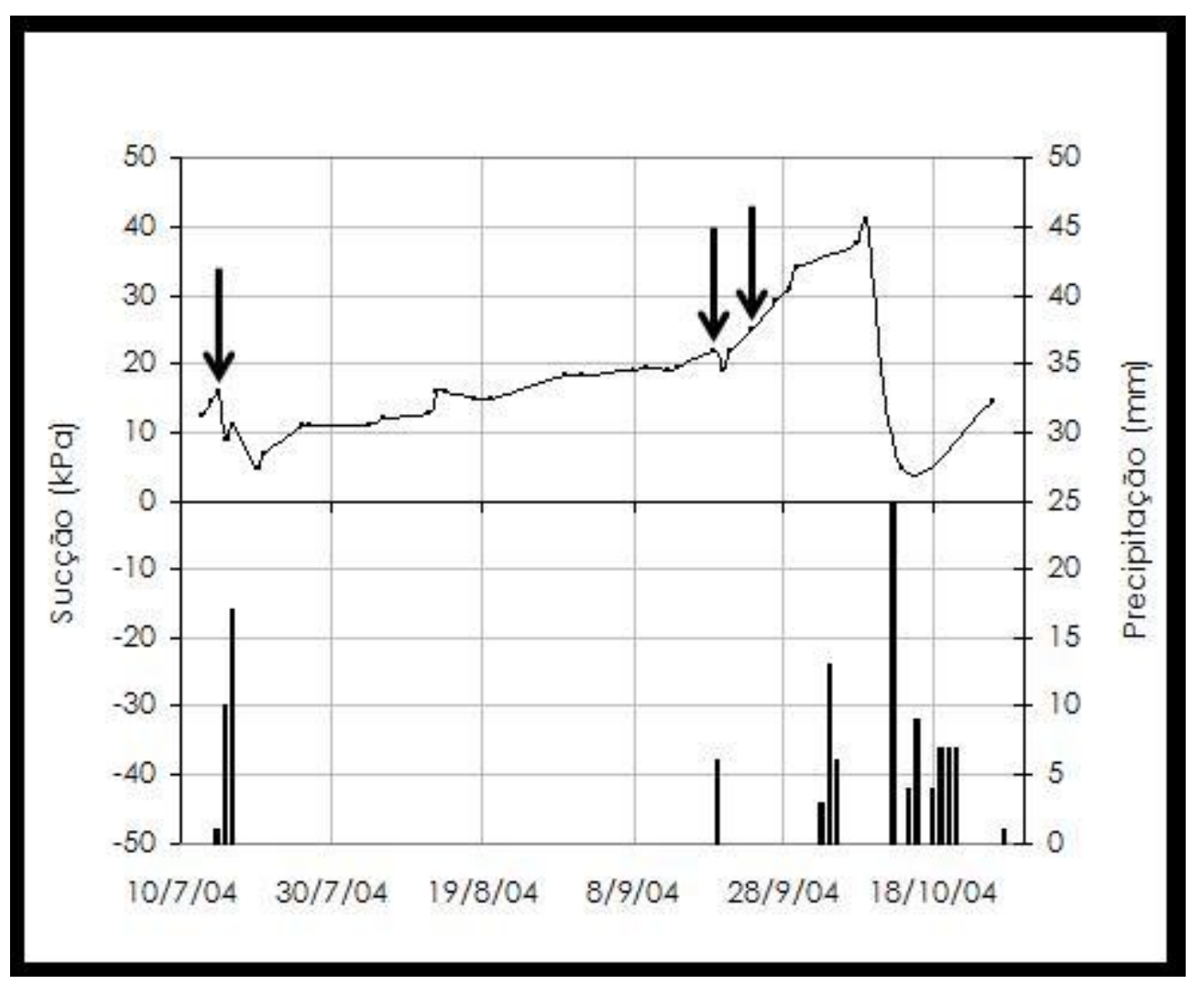

Figura 3.12 - Variação da sucção matricial e precipitação média diária ao longo do tempo, Moraes (2005)

Quanto ao modo de carregamento aplicado durante as provas de carga estática foram realizadas cinco do tipo lento (SML), dezesseis do tipo rápido (QML) e quatro do tipo misto (MML). As Figuras 3.13 a 3.16 mostram os resultados obtidos em ensaios sucessivos em quatro cavas, sendo duas não inundadas, ensaiadas através de prova de carga estática (Costa, 1999) e reensaiadas por Moraes (2005) com carregamento dinâmico seguido de estático novamente, em que as curvas obtidas com as provas de carga dinâmica "encaixam" razoavelmente bem entre as duas provas de carga estática. 


\section{Cava 9}

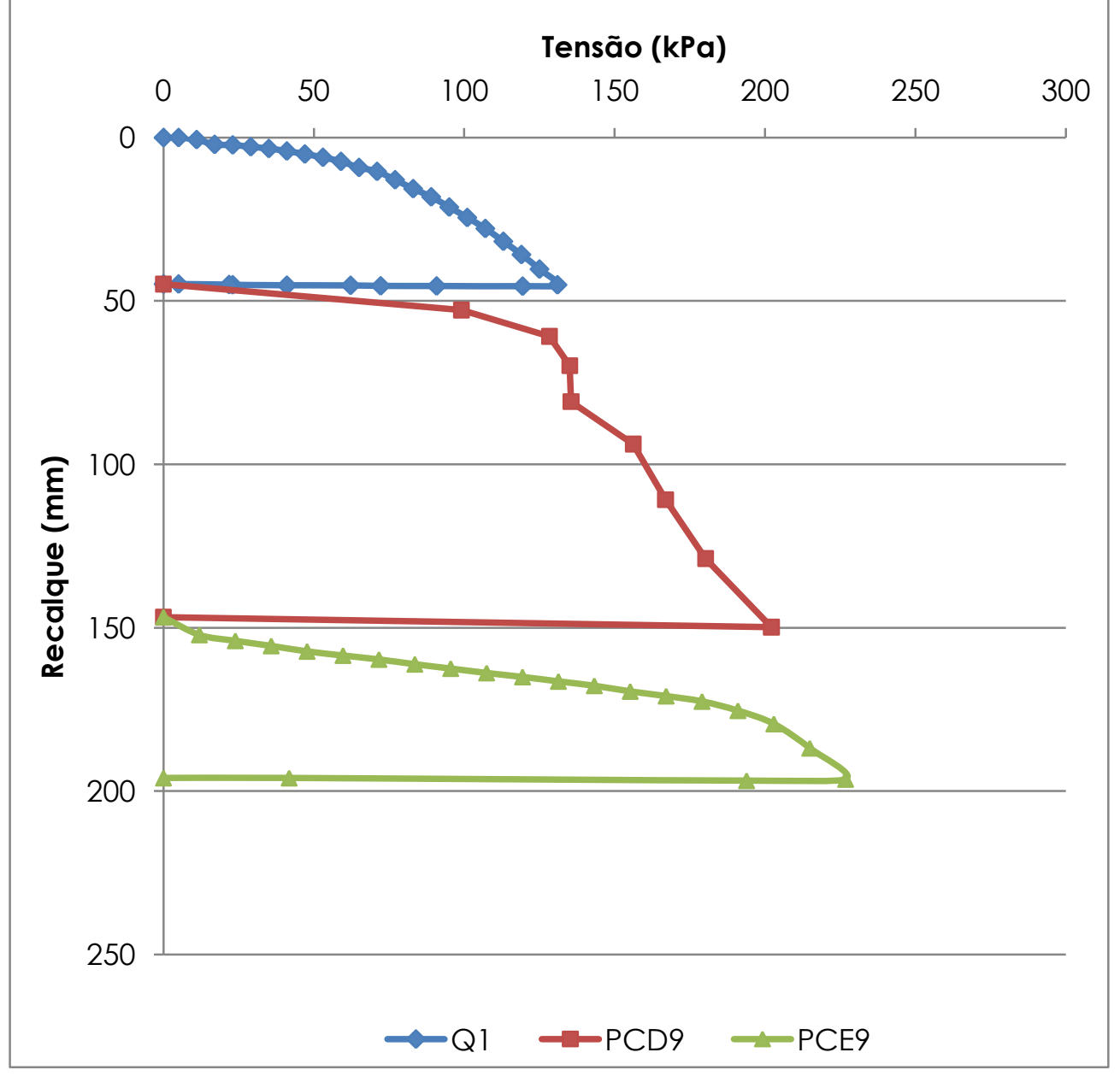

Figura 3.13 - Curvas tensão x recalque de três ensaios consecutivos: um dinâmico entre dois estáticos (cava 9, terreno não inundado), Moraes (2005) 


\section{Cava 4}

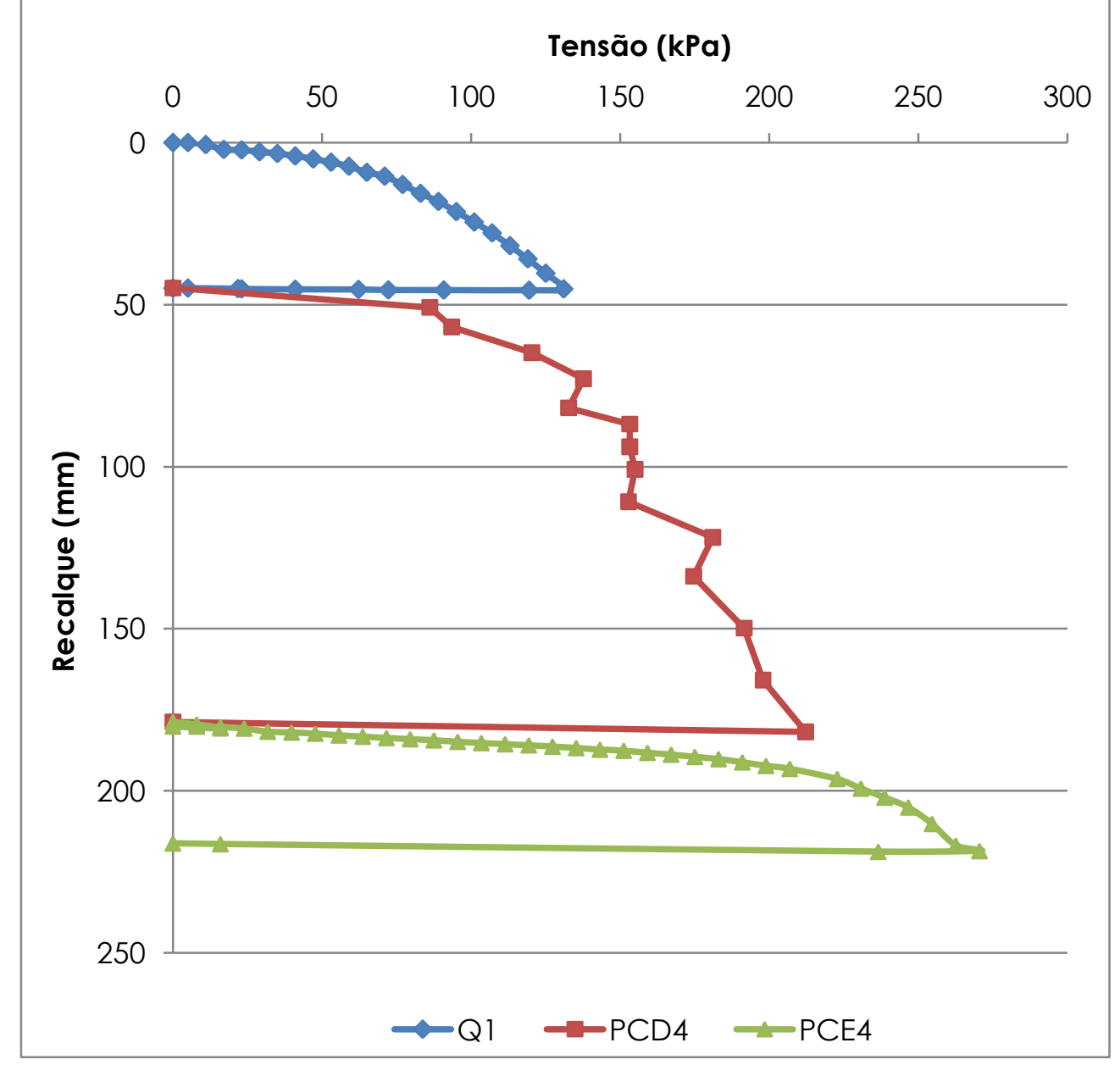

Figura 3.14 - Curvas tensão x recalque de três ensaios consecutivos: um dinâmico entre dois estáticos (cava 4, terreno não inundado), Moraes (2005) 


\section{Cava 7}

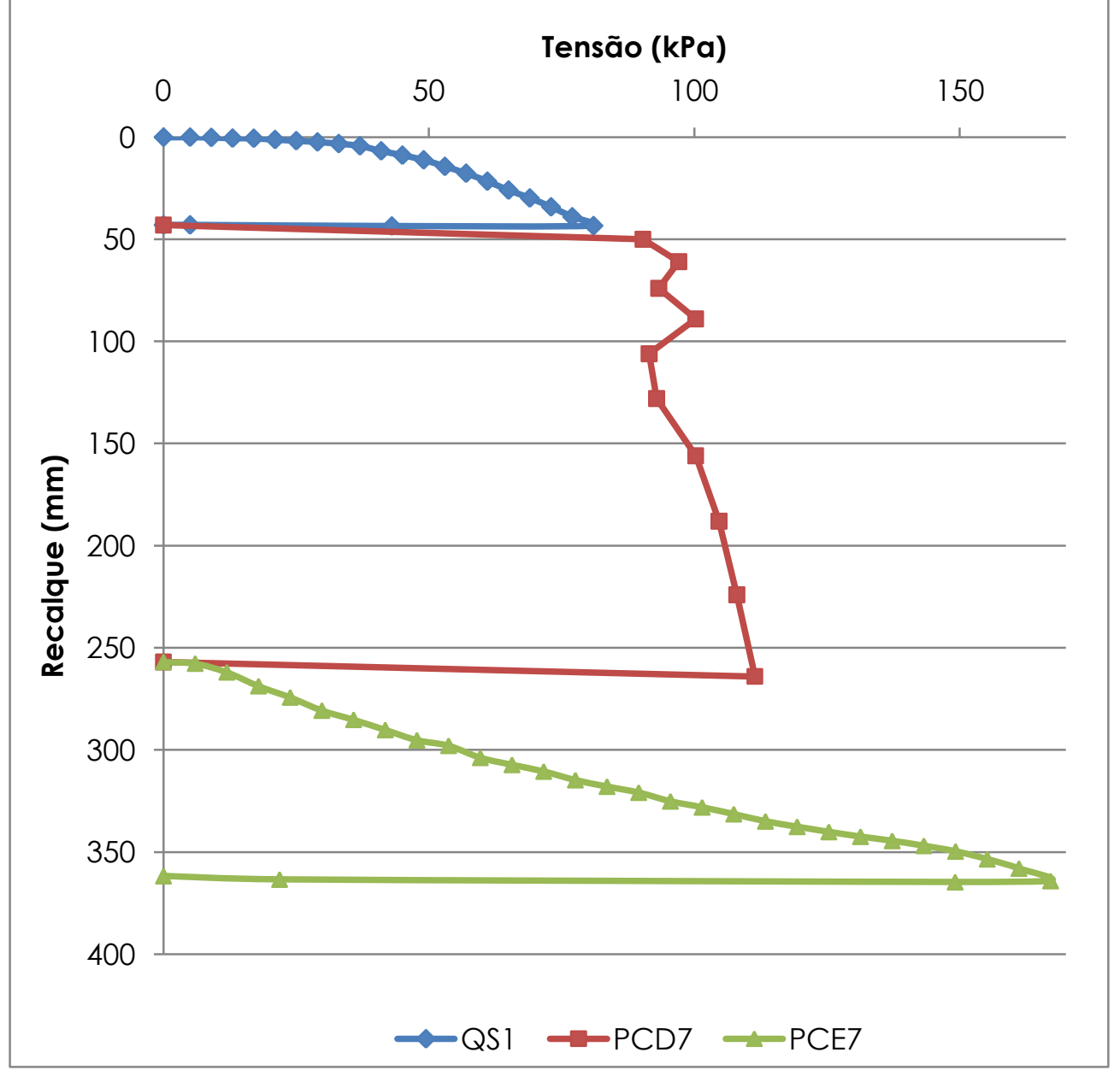

Figura 3.15 - Curvas tensão x recalque de três ensaios consecutivos: um dinâmico entre dois estáticos (cava 7, terreno inundado), Moraes (2005) 


\section{Cava 8}

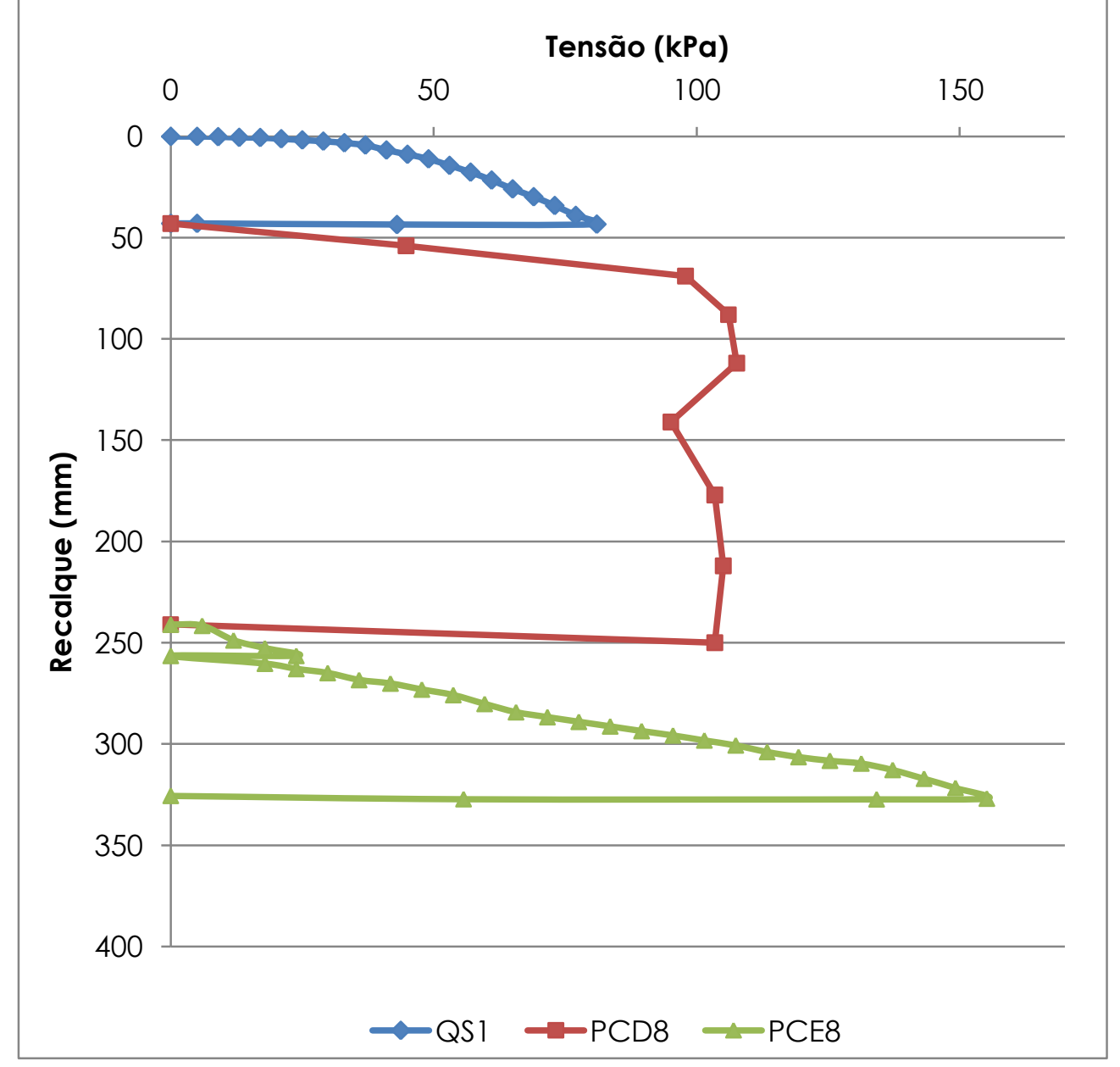

Figura 3.16 - Curvas tensão x recalque de três ensaios consecutivos: um dinâmico entre dois estáticos (cava 8, terreno inundado), Moraes (2005)

Nas provas de carga dinâmica, cada golpe do martelo foi acompanhado por monitoramento dinâmico utilizando-se o mesmo esquema usualmente empregado em estacas pré-moldadas. Para tornar possível o uso dessa instrumentação, a placa foi ligada a um tubo de aço com $7 \mathrm{~m}$ de comprimento e diâmetro externo igual a 0,22 m e parede de 8 mm. A $0,60 \mathrm{~m}$ da extremidade do tubo foram instalados dois acelerômetros e dois deflectômetros em posições diametralmente opostas, ligados ao analisador - PDA (Figura 3.17). 


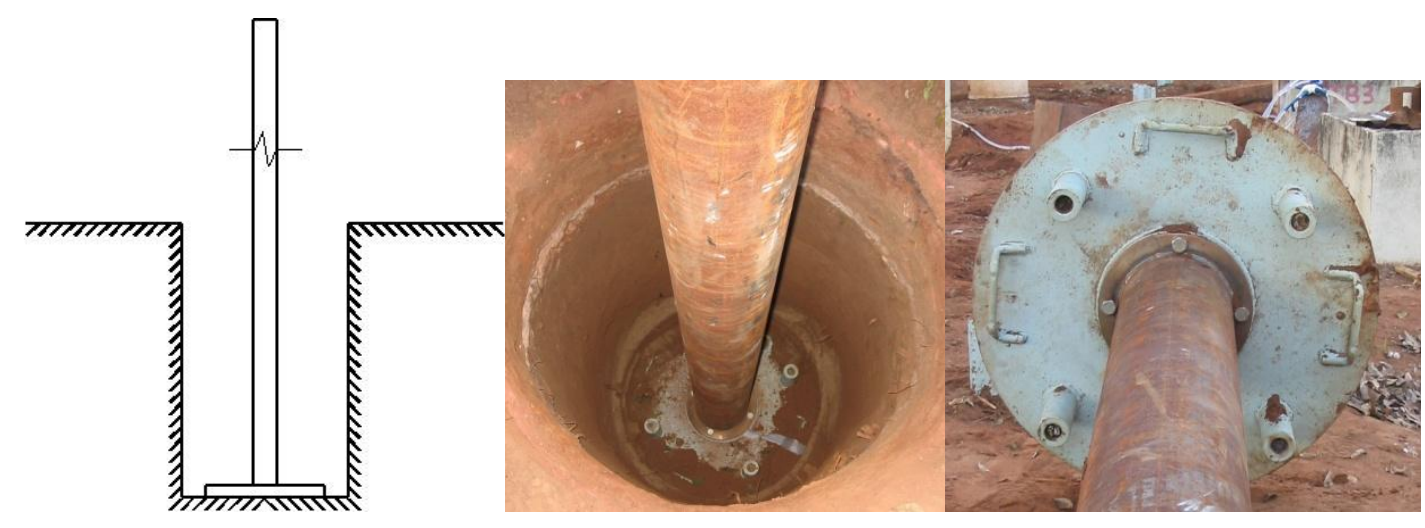

(a)

(b)

(c)

Figura 3.17 - (a) Corte transversal do esquema tubo-placa na cava; (b) Tubo e placa posicionados na cava após uma sequência de golpes do martelo; (c) Detalhe da ligação tubo-placa

Um bate-estaca com martelo de 15 kN efetuou as várias sequências de golpes, com alturas de queda crescentes. Todos os golpes do martelo registrados pela instrumentação foram analisados com o uso do software CAPWAP® para obter a parcela de resistência estática para cada deslocamento medido.

As tabelas 3.4 e 3.5 apresentam algumas características dos ensaios realizados por Moraes (2005) e Costa (1999).

Tabela 3.4 - Características das provas de carga realizadas por Moraes (2005)

\begin{tabular}{|c|c|c|c|c|}
\hline Cava & Tipo de ensaio & Denominação & Sucção Matricial $(\mathrm{kPa})$ & Pré-inundação \\
\hline 4 & QML & PCE4 & 22 & não \\
\hline 4 & Dinâmico & PCD4 & 16 & não \\
\hline 9 & QML & PCE9 & 25 & não \\
\hline 9 & Dinâmico & PCD9 & 16 & não \\
\hline 7 & QML & PCE7 & $\cong 0$ & sim \\
\hline 7 & Dinâmico & PCD7 & $\cong 0$ & sim \\
\hline 8 & QML & PCE8 & $\cong 0$ & sim \\
\hline 8 & Dinâmico & PCD8 & $\cong 0$ & sim \\
\hline
\end{tabular}


Tabela 3.5 - Características das provas de carga realizadas por Costa (1999)

\begin{tabular}{|c|c|c|c|}
\hline Tipo de ensaio & Denominação & Sucção Matricial (kPa) & Pré-inundação \\
\hline QML & Q1 & 15 & não \\
\hline QML & QS1 & $\cong 0$ & sim \\
\hline
\end{tabular}

\section{TUBULÕES A CÉU ABERTO}

Em 13 tubulões escavados a céu aberto, sendo 8 com bases alargadas de 1,5 m de diâmetro e o restante sem bases alargadas, foram realizadas 10 provas de carga estática (Carneiro, 1999) e 22 provas de carga dinâmica (Campelo, 2000). Para as provas de carga estática, seis tubulões foram instrumentados com duas linhas de extensômetros elétricos (strain-gages), em seis níveis e extensômetros de haste (tell-tales) em quatro níveis. Nas Figuras 3.18 a 3.23 são apresentados os resultados obtidos nas provas de carga estática. 


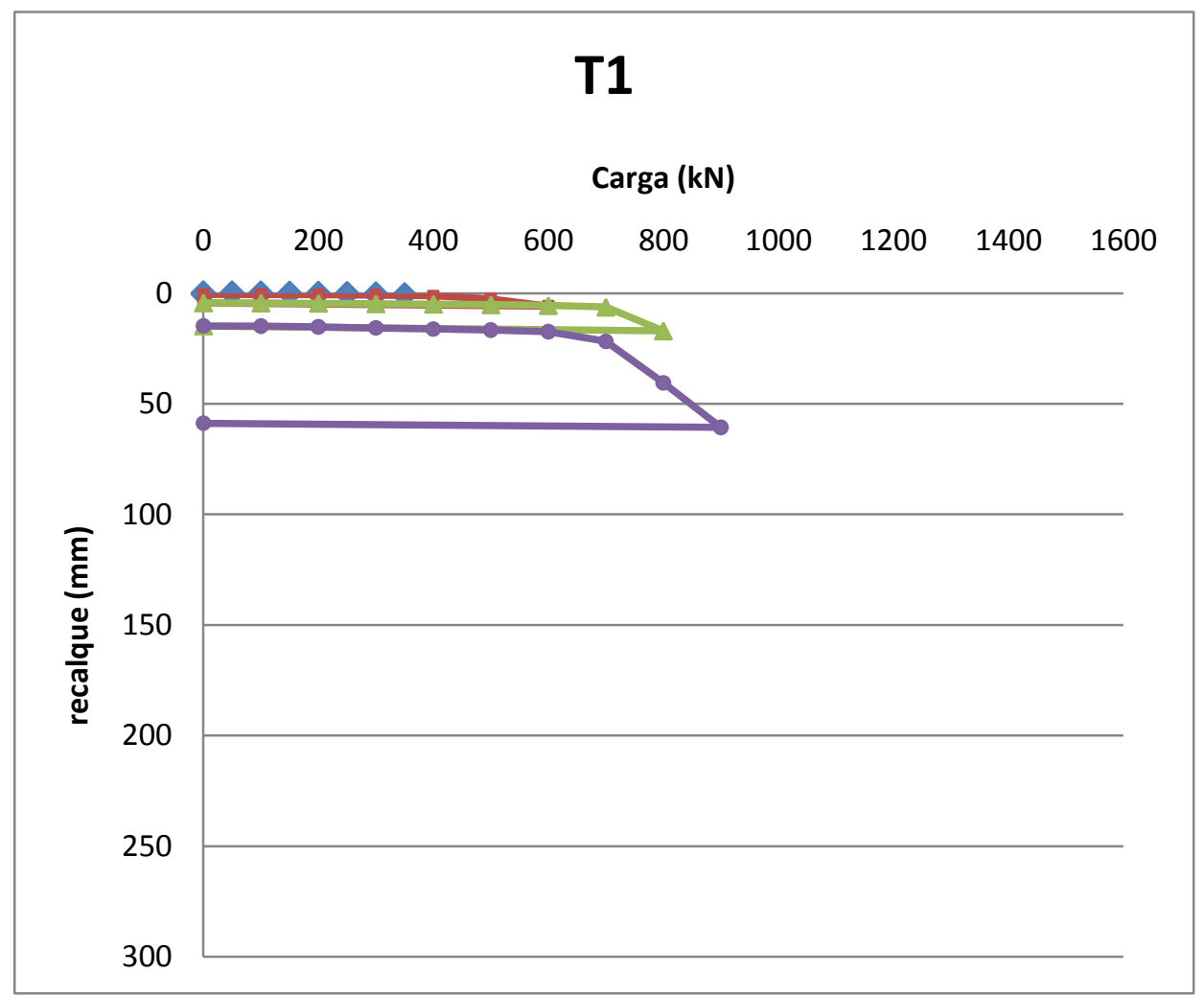

Figura 3.18 - Tubulão com base alargada, ensaiado em terreno previamente inundado (Carneiro, 1999) 


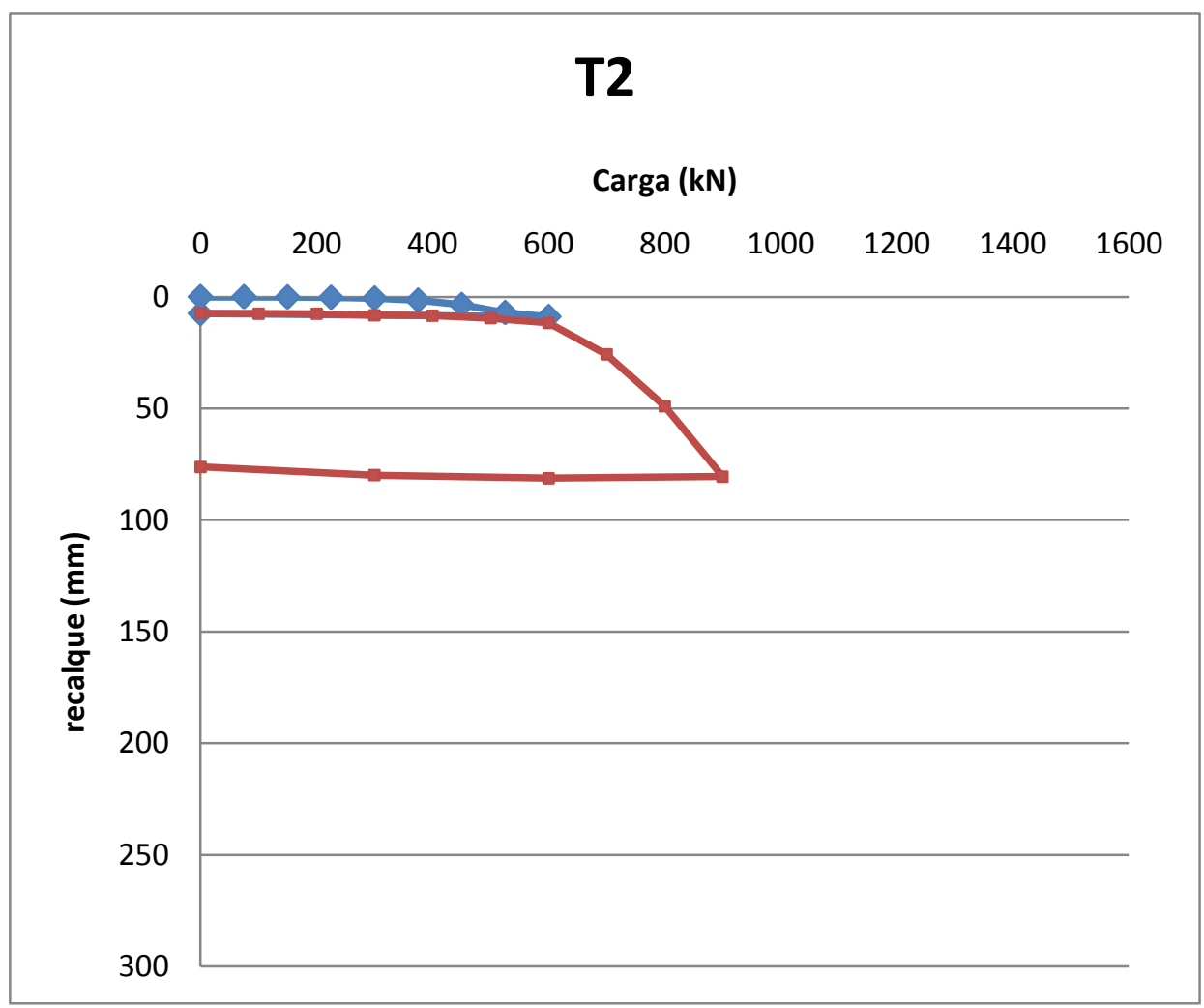

Figura 3.19 - Tubulão com base alargada, ensaiado em terreno previamente inundado (Carneiro, 1999) 


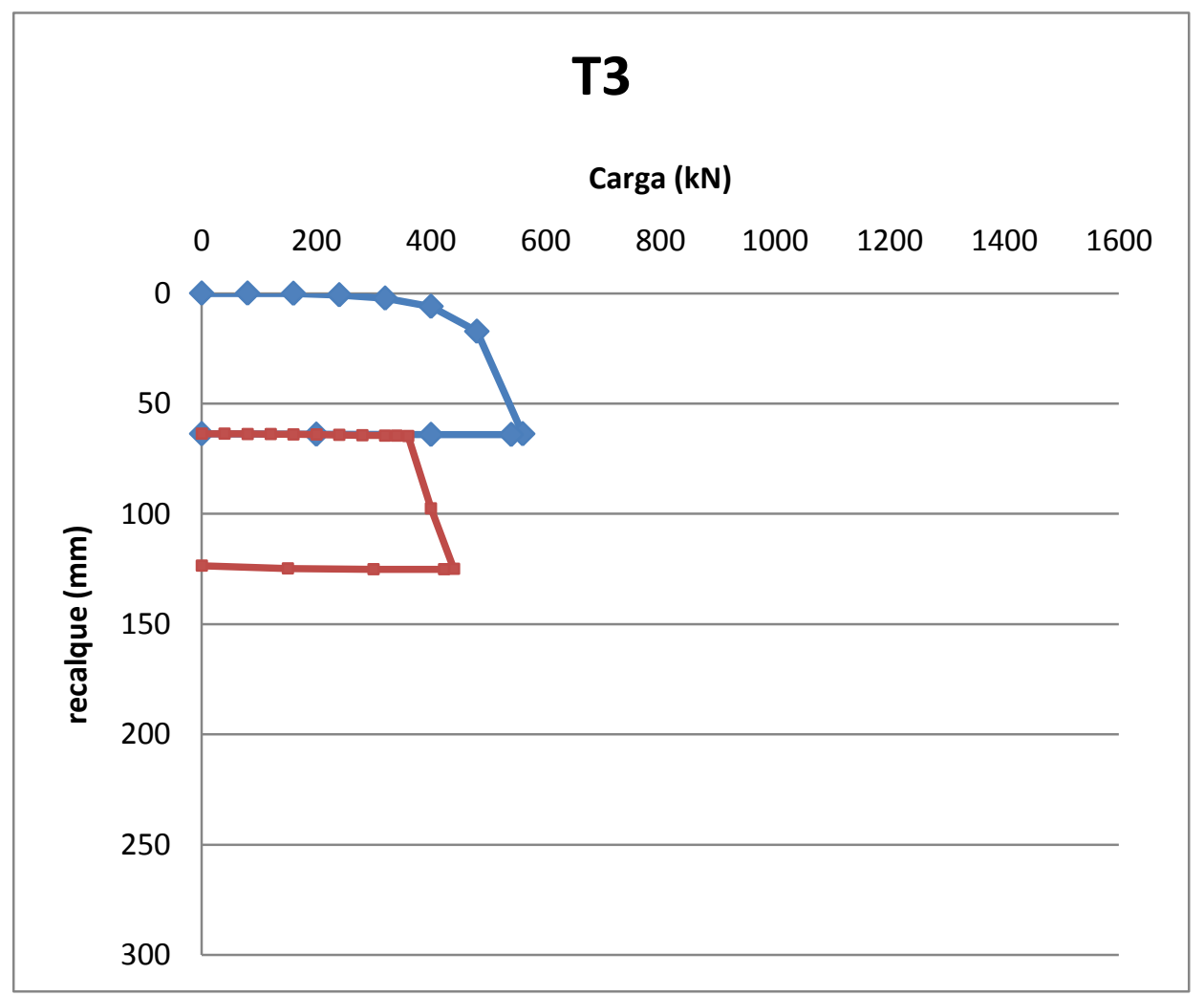

Figura 3.20 - Tubulão sem base alargada, ensaiado primeiramente em terreno não inundado (nível d'água igual a 7,0 m) e posteriormente com terreno previamente inundado (Carneiro, 1999) 


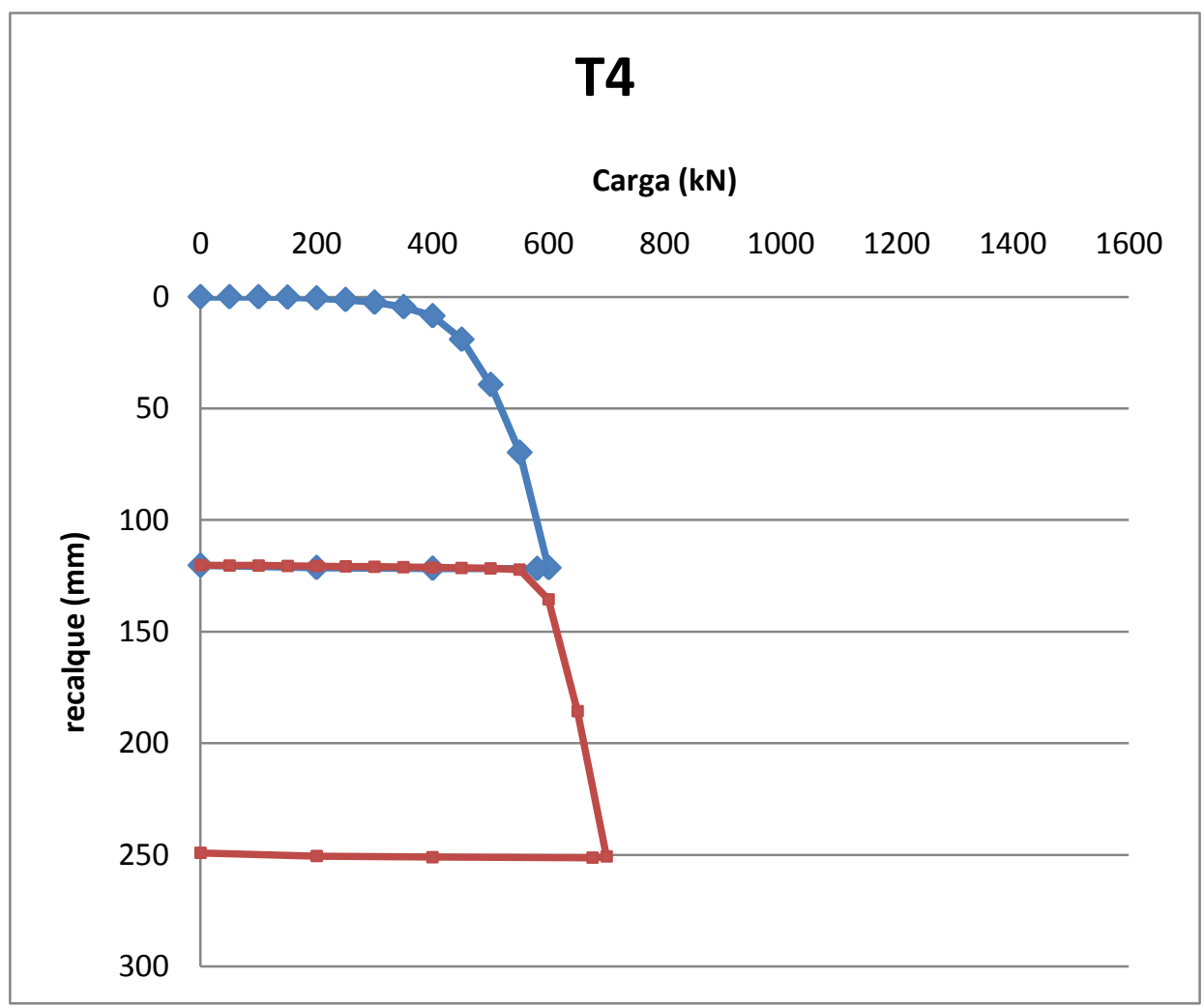

Figura 3.21 - Tubulão sem base alargada, ensaiado em terreno não inundado, com nível d'água igual a 7,9 m no primeiro ensaio e 8,0 m no segundo (Carneiro, 1999) 


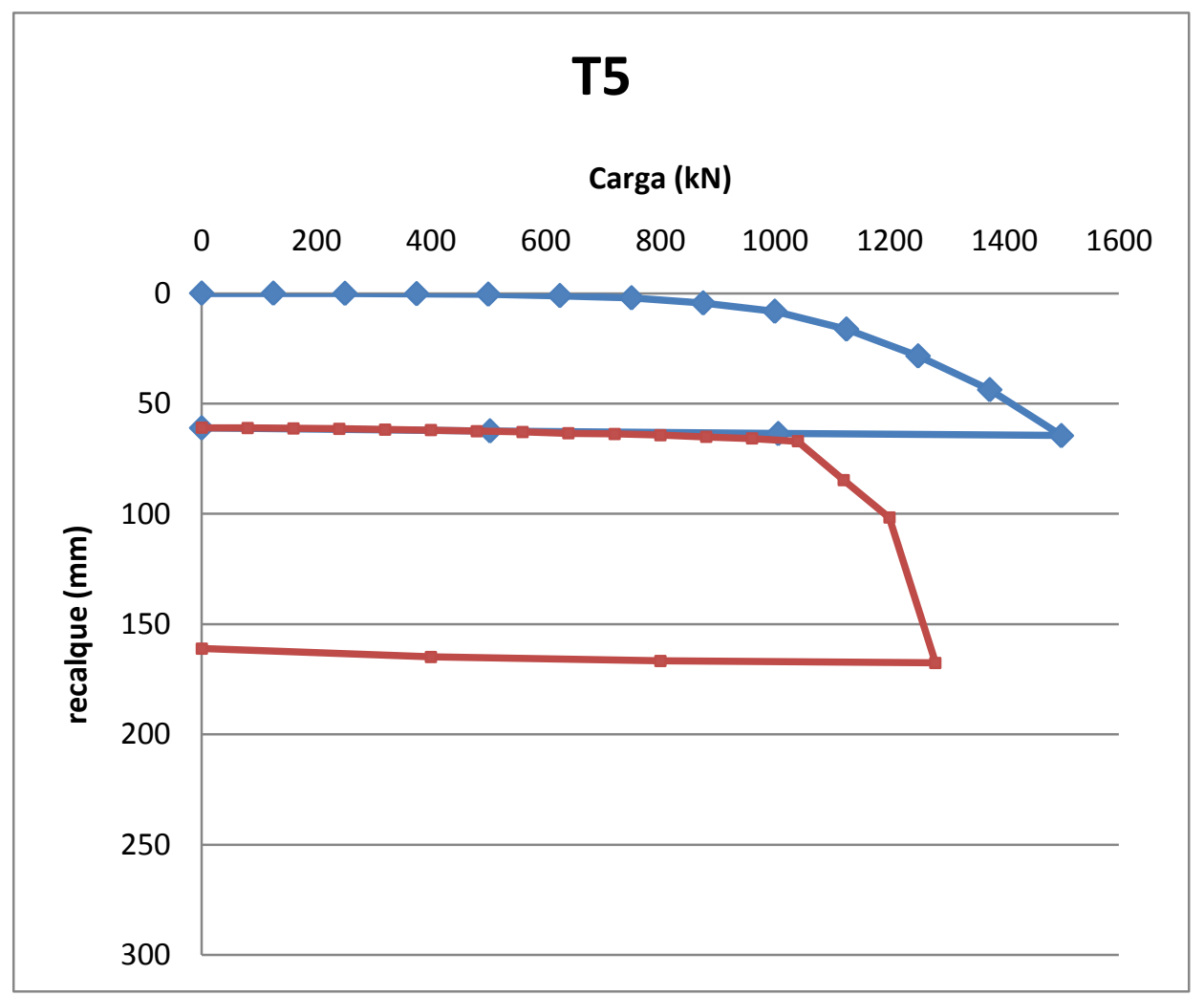

Figura 3.22 - Tubulão com base alargada, ensaiado primeiramente em terreno não inundado (nível d'água igual a 10,6 m) e posteriormente com terreno previamente inundado (Carneiro, 1999) 


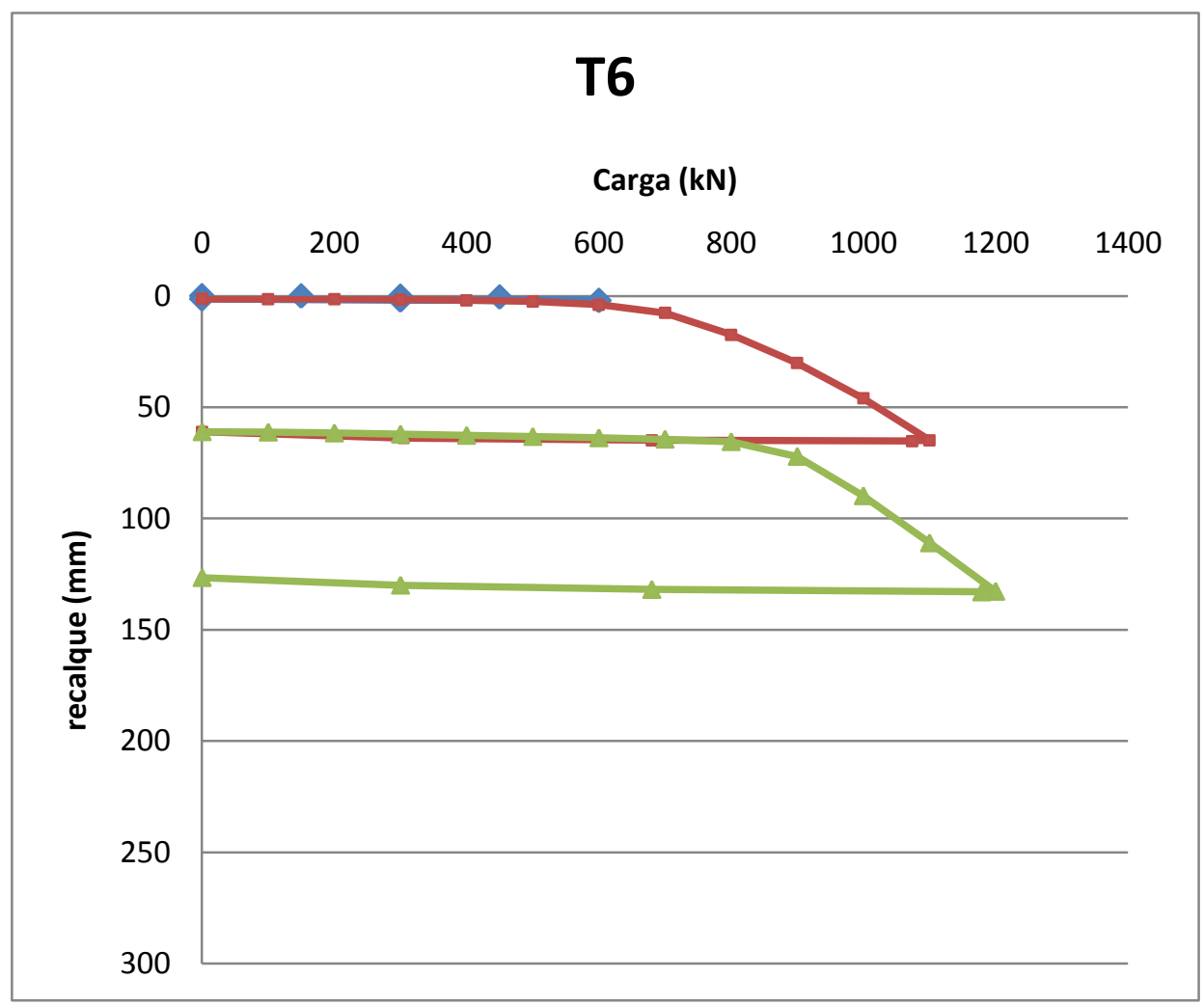

Figura 3.23 - Tubulão com base alargada. O primeiro ensaio foi interrompido devido à inundação acidental da cava (o nível d'água estava a 10,5 m). O segundo ensaio foi feito em terreno não inundado (com nível d'água igual a 7,2 m) e o terceiro com terreno previamente inundado (Carneiro, 1999)

Na Tabela 3.6 encontram-se algumas características das provas de carga realizadas por Carneiro (1999).

Tabela 3.6 - Características das provas de carga realizadas por Carneiro (1999)

\begin{tabular}{|c|c|c|c|c|c|}
\hline Tubulão & Ensaios & Tipo de ensaio & Base alargada & Nível d'água & Pré-inundação \\
\hline 1 & 4 & SML & $\operatorname{sim}$ & 7,$0 ; 7,1$ e $7,1 \mathrm{~m}^{*}$ & $\operatorname{sim}$ \\
\hline 2 & 2 & $\mathrm{SML}$ & $\operatorname{sim}$ & $7,2 \mathrm{~m}^{*}$ & $\operatorname{sim}$ \\
\hline 3 & 2 & $\mathrm{SML}$ & não & 7,0 e $7,1 \mathrm{~m}$ & não/sim \\
\hline 4 & 2 & $\mathrm{SML}$ & não & 7,9 e $8,0 \mathrm{~m}$ & não \\
\hline 5 & 2 & $\mathrm{SML}$ & $\operatorname{sim}$ & 10,6 e $7,0 \mathrm{~m}$ & não/sim \\
\hline 6 & 3 & $\mathrm{SML}$ & $\operatorname{sim}$ & 10,$5 ; 7,2$ e $7,5 \mathrm{~m}$ & $\mathrm{não} / \mathrm{sim}$ \\
\hline
\end{tabular}

*o nível d'água não foi medido no primeiro ensaio 
Posteriormente, em quatro tubulões executados com o fuste separado da base por placas de isopor foram realizadas 10 provas de carga estática (Santos, 2001) e 10 provas de carga dinâmica (Soares, 2003). As placas de isopor (E.P.S.) foram introduzidas durante a concretagem com o objetivo de, durante a realização dos ensaios, obter separadamente as parcelas de resistência de base e por atrito lateral.

Benvenutti (2001) executou mais dois tubulões a céu aberto, com fuste de diâmetro de $0,50 \mathrm{~m}$ e base apoiada à cota $6,00 \mathrm{~m}$. O primeiro tubulão foi ensaiado na condição nãoinundada do solo, na cota inicial de apoio da base e sucessivamente, com a cravação de 0,15 m, 0,30 m e 0,45 m, o que corresponde a 10\%, 20\% e 30\% do diâmetro da base, respectivamente. Observou-se que a cravação majorou a capacidade de carga em 42\%, $85 \%$ e $12 \%$, respectivamente. O segundo tubulão foi ensaiado com o solo pré-inundado, para quantificar o efeito da colapsibilidade do terreno na redução da capacidade de carga. Constatou-se uma redução de $51 \%$ a $53 \%$ nos valores de capacidade de carga anteriormente obtidos. Mas a carga de colapso, ou capacidade de carga na condição inundada, também teve uma majoração importante, aumentando em 45\%, $90 \%$ e 135\% com a cravação de 10\%, 20\% e 30\% do diâmetro da base, respectivamente.

Nos resultados obtidos por Benvenutti (2001) as curvas carga-recalque são do tipo aberta. Nas Figuras 3.24 e 3.25, observa-se que a parte final das curvas de três ensaios sucessivos de um mesmo tubulão constituem aproximadamente um único trecho reto. Em outras provas de carga estática realizadas em placas, sapatas e tubulões no terreno do campo experimental, observa-se que as curvas carga-recalque não caracterizam ruptura nítida, sistematicamente. No trecho final das curvas há uma mobilização crescente de resistência com o aumento do recalque, de forma praticamente linear. 


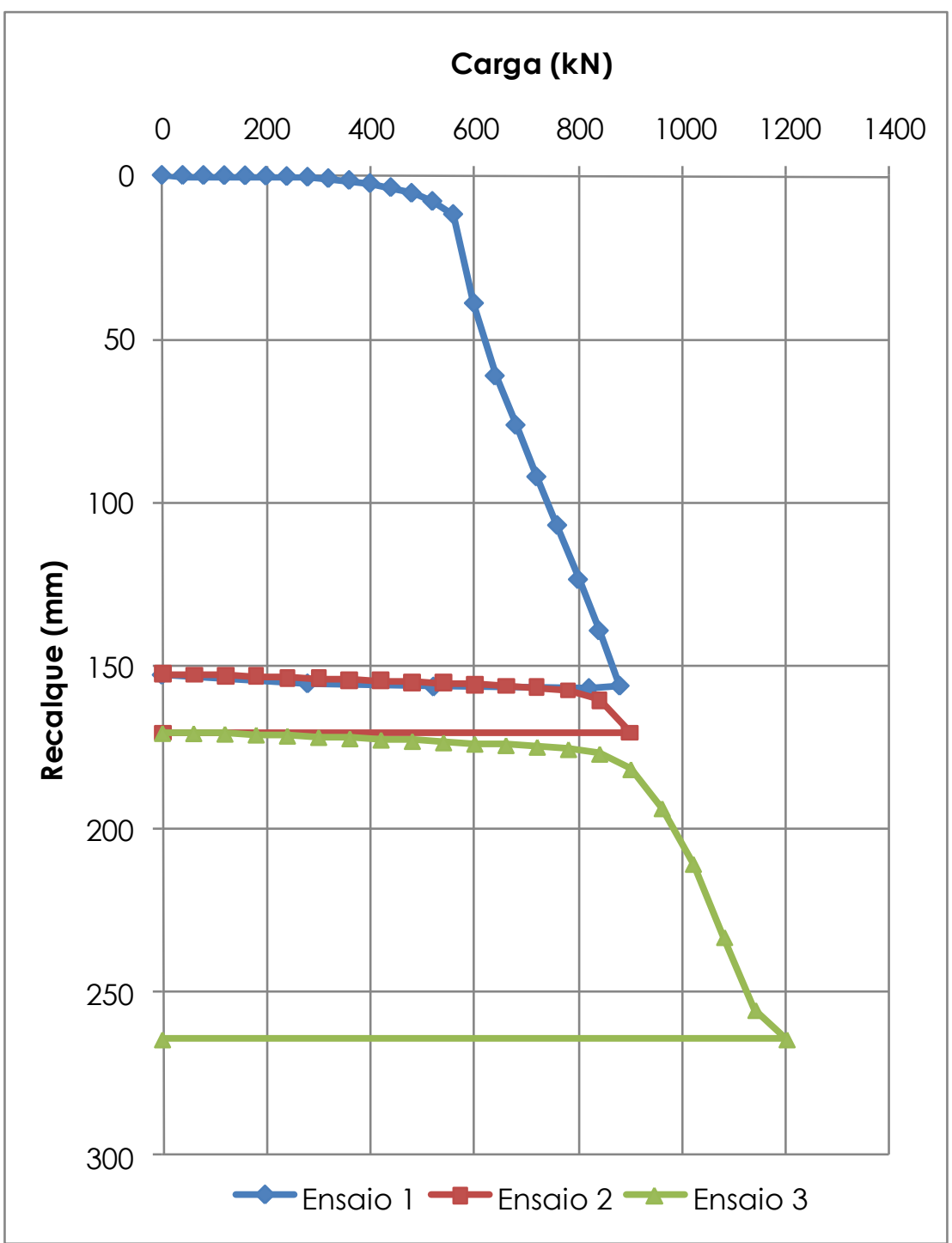

Figura 3.24 - Curvas carga-recalque de três ensaios em tubulão a céu aberto, com solo não inundado (Benvenutti, 2001) 


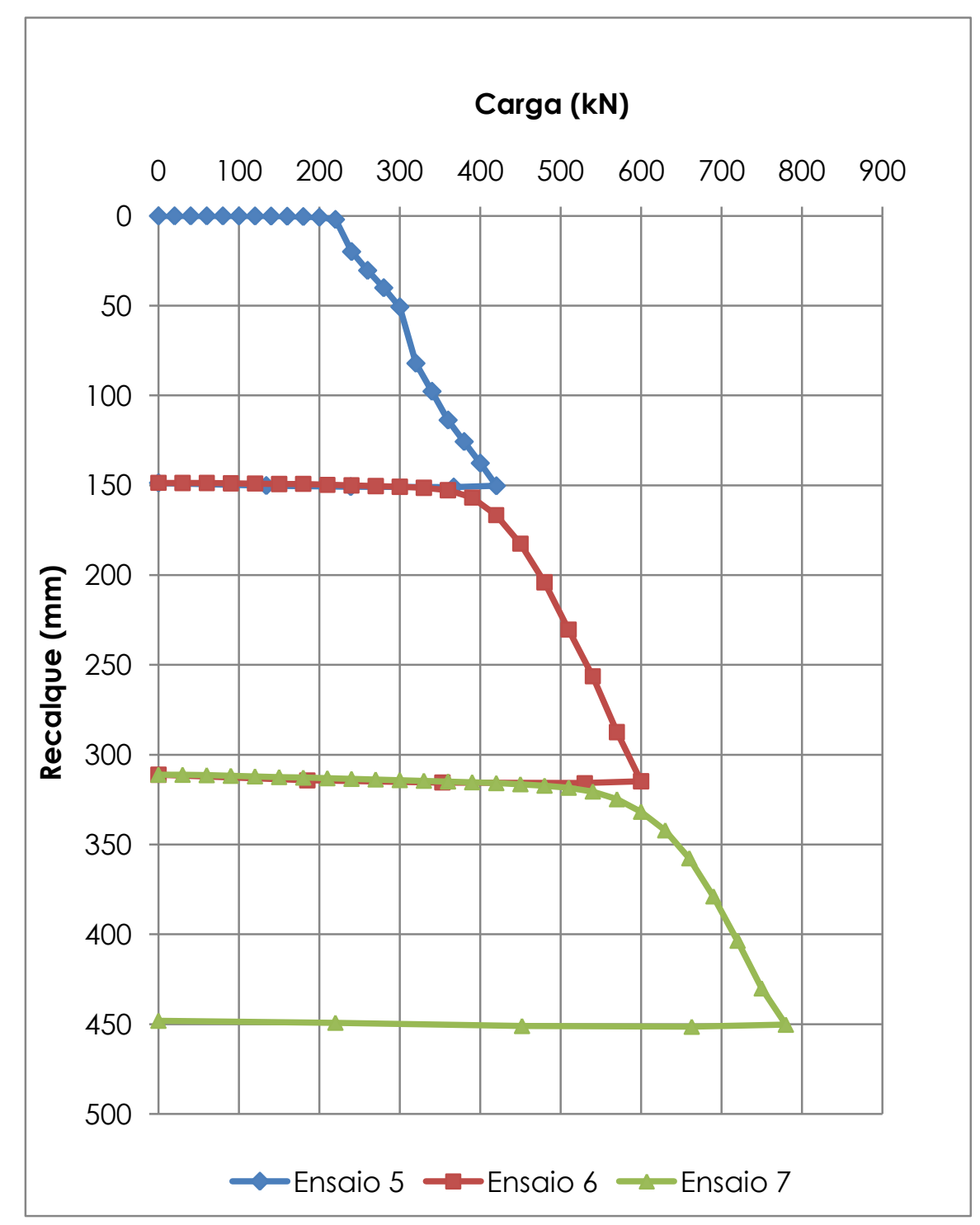

Figura 3.25 - Curvas carga-recalque de três ensaios em tubulão a céu aberto, com solo previamente inundado (Benvenutti, 2001)

\section{ESTACAS ESCAVADAS}

Foram realizadas provas de carga à tração (Carvalho, 1991) e seis provas de carga do tipo lenta à compressão (Mantilla, 1992) em três estacas escavadas, instrumentadas, com 10 metros de comprimento e $0,35 \mathrm{~m}, 0,40 \mathrm{~m}$ e $0,50 \mathrm{~m}$ de diâmetro (Figura 3.26). A instrumentação consistiu de extensômetros elétricos de resistência colados nas armaduras e de hastes medidoras de deslocamentos. Instalou-se esta instrumentação em cinco níveis ao 
longo da profundidade das estacas. Teixeira (1993) realiza três provas de carga SML nas mesmas estacas. As estacas também foram ensaiadas com carregamento rápido (QML).

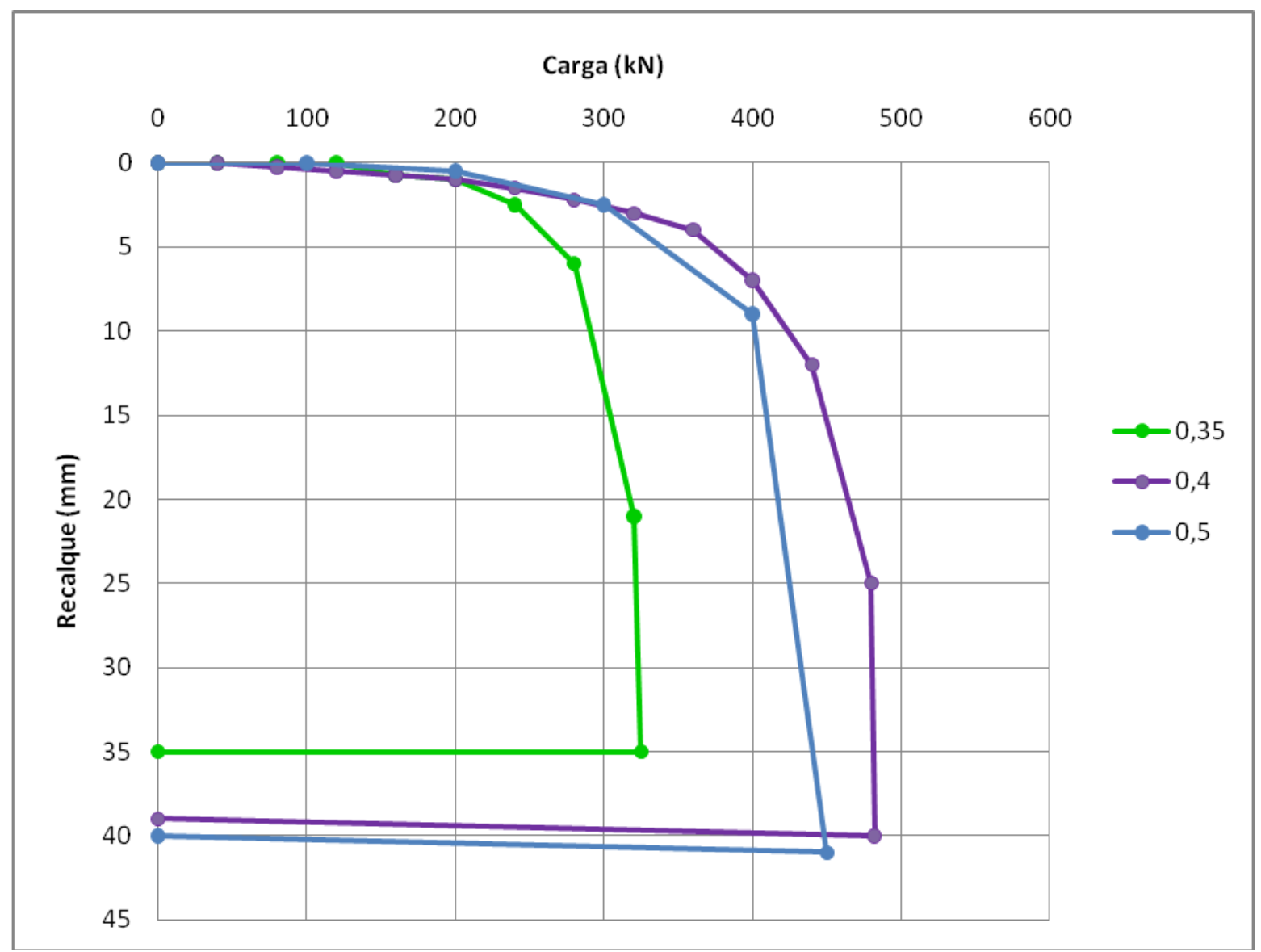

Figura 3.26 - Estacas escavadas com diâmetros iguais a 0,35, 0,40 e 0,50 m; com comprimentos iguais a 10,60 m; ensaiadas à compressão com carregamento lento (Mantilla, 1992) 


\section{MATERIAIS E MÉTODOS}

No campo experimental de fundações do Departamento de Geotecnia da USP/São Carlos foram realizadas quatro provas de carga estática com carregamento rápido em quatro bases injetadas com calda de cimento portland, executadas próximas à superfície, sob cilindros de concreto com diâmetro igual a $0,80 \mathrm{~m}$ e comprimento igual a $1,80 \mathrm{~m}$. Também foram realizadas sete provas de carga estática com carregamento lento em cinco estacas com base injetada. Foram também executadas quatro estacas escavadas para compor os sistemas de reação das provas de carga em conjunto com estacas trilho e tubulões existentes. A Figura 4.1 mostra a locação dos cilindros e estacas.

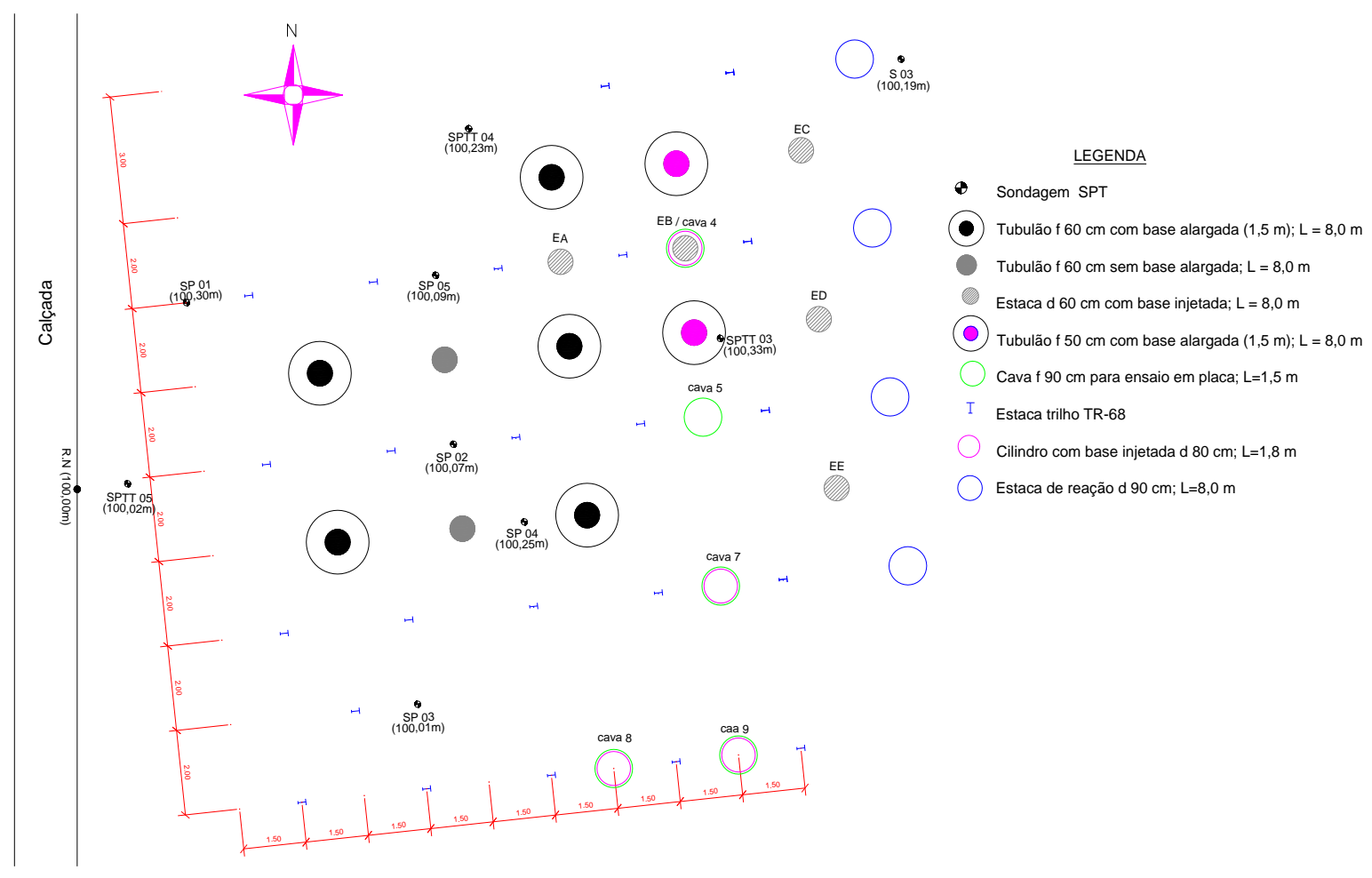

Figura 4.1 - Disposição dos cilindros e estacas executadas no Campo Experimental da USP/São Carlos 


\subsection{EXECUÇÃO DOS CILINDROS}

Foram executados quatro cilindros em concreto armado (dimensionada a armadura mínima), com diâmetro igual a $0,80 \mathrm{~m}$. Na armadura dos cilindros (Figura 4.2) foram colocados cinco tubos de PVC com comprimento igual a 2,0 m e bitola de 1", sendo quatro tubos amarrados nas ferragens de comprimento $1,5 \mathrm{~m}$ e um tubo amarrado no centro. As pontas dos tubos foram posicionadas a $10 \mathrm{~cm}$ de distância das pontas das armaduras. Os conjuntos armaduras mais tubos foram colocados em quatro cavas escavadas manualmente com 1,8 m de profundidade, e diâmetro igual a 0,80 m na base, chegando a $0,95 \mathrm{~m}$ na superfície. Anteriormente à concretagem, $15 \mathrm{~cm}$ de altura de solo solto foi jogado nas cavas, a fim de evitar contaminação da ponta dos tubos pelo concreto. Além da proteção de solo, as pontas dos tubos foram protegidas com caps de PVC.

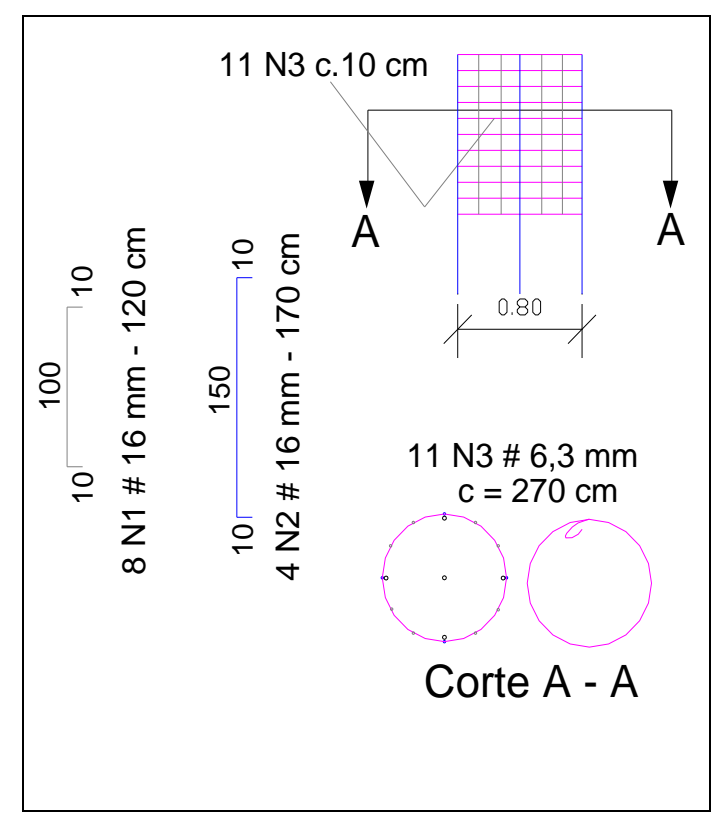

Figura 4.2 - Armação dos cilindros de concreto

Em seguida, os cilindros foram concretados, utilizando-se concreto usinado com fck igual a 30 MPa. Durante a concretagem (Figura 4.3), o concreto foi vibrado utilizando-se um vibrador de imersão (mangote). 
A disposição final dos tubos, após a concretagem, é mostrada na Figura 4.4. Os tubos têm diâmetro externo igual a $30 \mathrm{~mm}$ e altura a partir do concreto em torno de $50 \mathrm{~cm}$.

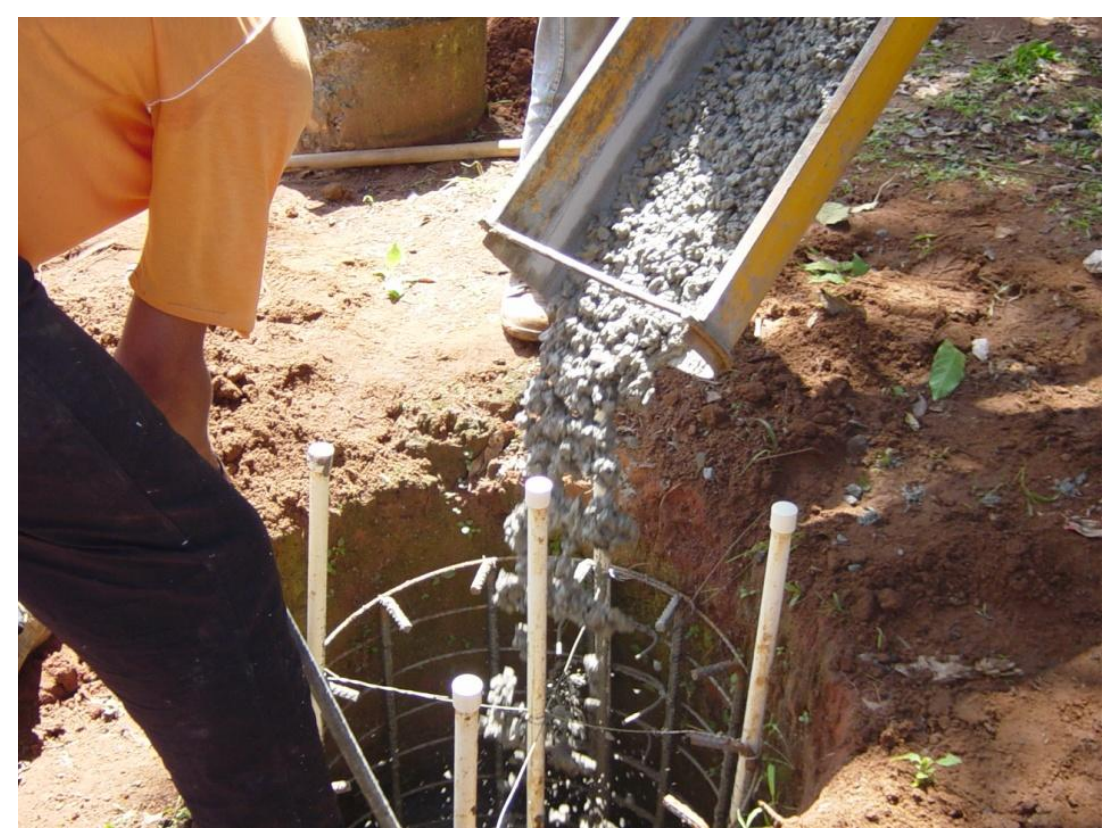

Figura 4.3 - Concretagem

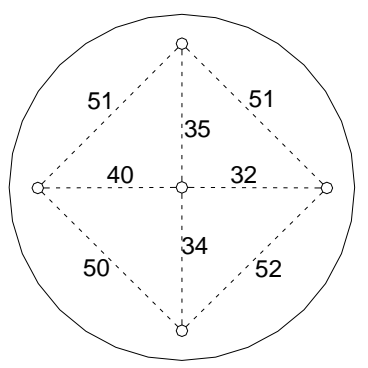

(a)

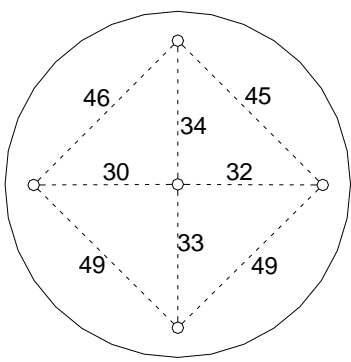

(b)

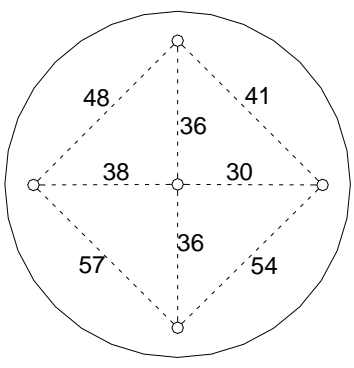

(c)

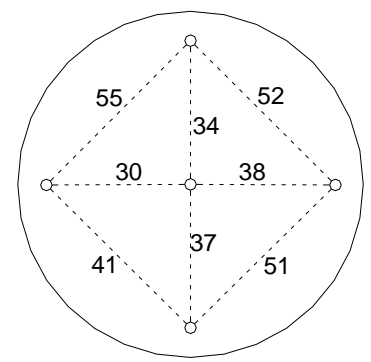

(d)

Figura 4.4 - Disposição dos tubos após a concretagem. Distâncias entre os tubos sem escala com medidas em cm. (a) cilindro 4; (b) cilindro 9; (c) cilindro 7 e (d) cilindro 8

Uma semana antes das injeções, os caps que protegiam as cabeças dos tubos foram substituídos por conectores de PVC com rosca metálica. Os conectores foram colados com adesivo especial para PVC de alta pressão. O sistema injetor montado era rosqueado ao conector utilizando-se uma união. 


\subsection{EXECUÇÃO DAS BASES INJETADAS SOB OS CILINDROS}

Após a cura do concreto dos cilindros, deu-se início à etapa de injeções. Todo o sistema injetor foi montado a partir de peças metálicas disponíveis comercialmente. Para as peças em PVC, tomou-se o cuidado de usar tubos e conexões próprios para água quente, pois estes possuem pressão de serviço igual a $2.400 \mathrm{kPa}$, quando utilizados sob temperatura igual a $20^{\circ} \mathrm{C}$. Tubos e conexões comuns (água fria) suportam $750 \mathrm{kPa}$ a $20^{\circ} \mathrm{C}$, e as pressões de injeção ultrapassaram este valor. Ao sistema injetor foram acoplados dois tês. Num deles foi colocada uma válvula de escape, que era aberta ao final de cada injeção, para despressurizar o sistema e desconectá-lo com segurança. O outro tê fazia a ligação com um transmissor de pressão da marca Zurich, com faixa de trabalho de 0 a $1.000 \mathrm{kPa}$. 0 transdutor ficava em contato com a calda de cimento, protegido por um diafragma de borracha, e era ligado a um leitor digital. O sistema pode ser visto nas Figuras 4.5 a 4.7.

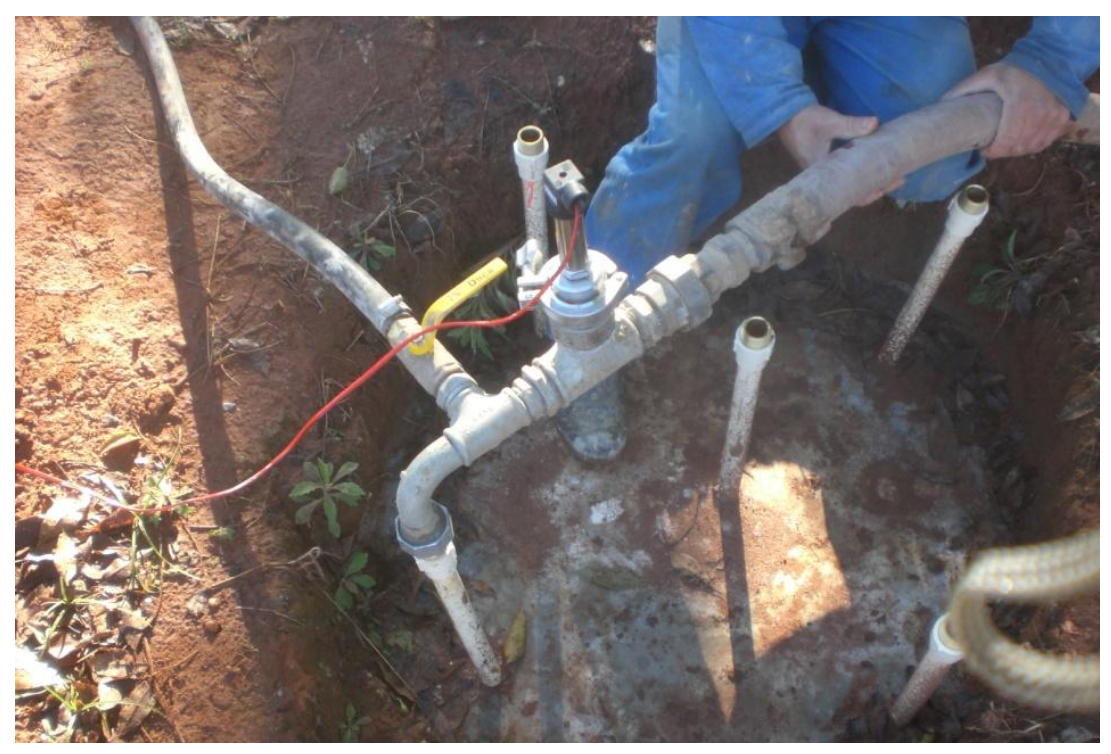

Figura 4.5 - Execução da injeção 


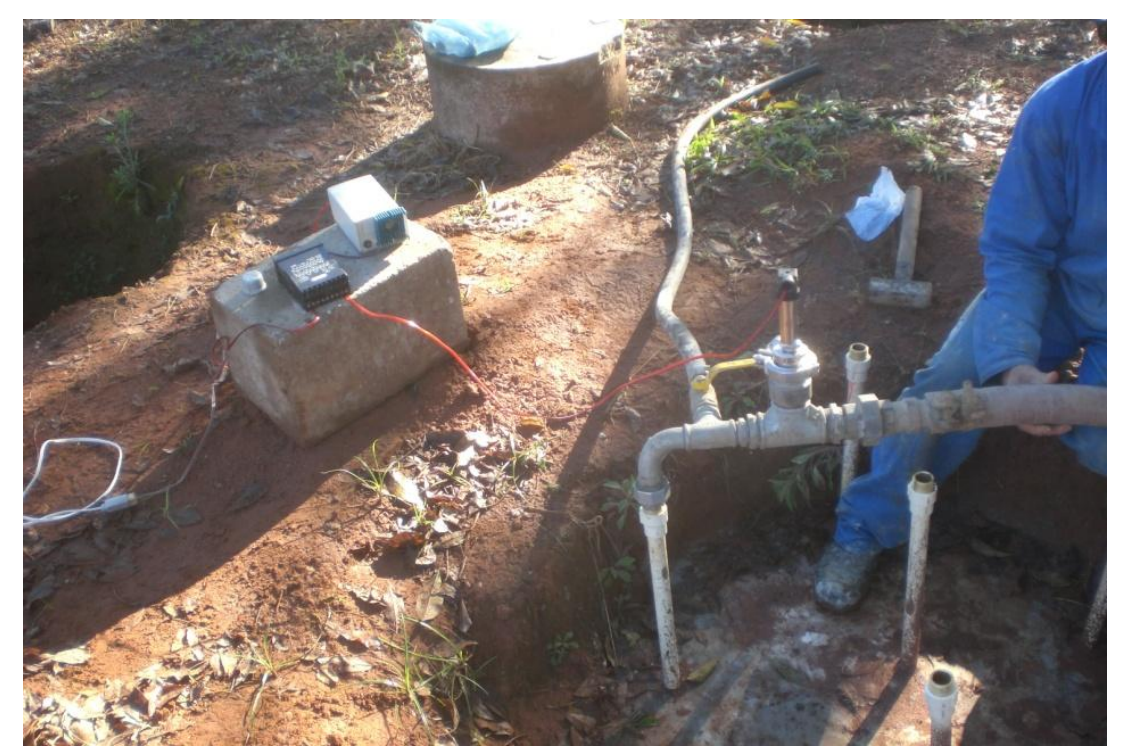

Figura 4.6 - Sistema injetor

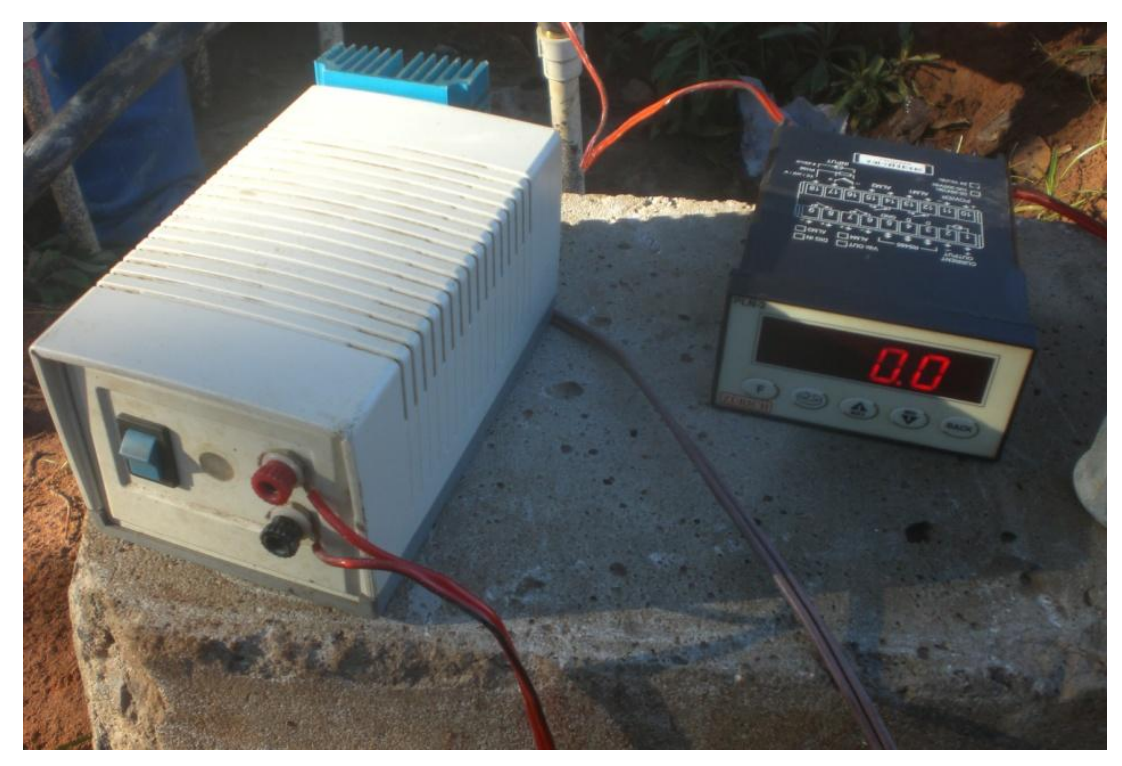

Figura 4.7 - Leitor de pressões

Para pressurizar a calda de cimento foi utilizada uma bomba de pistão, elétrica trifásica, com potência igual a 7,5 HP. Este tipo de unidade hidráulica é normalmente alimentada por uma argamasseira, quando usada, por exemplo, para execução de estacaraíz. A argamasseira foi dispensada, como forma de redução de custos, e foi construído um 
grande funil para alimentar a bomba. A calda, com fator água/cimento igual a 0,55, era misturada e a agitação era mantida utilizando-se uma betoneira de propriedade do departamento de geotecnia.

Foi adotada uma pressão máxima igual $1.000 \mathrm{kPa}$. Essa pressão foi adotada pela limitação do transdutor de pressão utilizado.

Foi adotado inicialmente que a pressão imposta pela injeção afetaria o maciço isotropicamente, e empurraria o cilindro de concreto para cima. Como a pressão de injeção máxima a ser utilizada seria de $1.000 \mathrm{kPa}$, e a área da base do cilindro igual a 0,5 m², a força resultante é de $500 \mathrm{kN}$. O peso próprio de cada cilindro é de aproximadamente 20 kN e o atrito lateral calculado pelo método Aoki-Velloso é igual a 23 kN. Como a tendência era que o cilindro fosse expulso do solo, foi montado um pórtico sobre o cilindro para impedir seu deslocamento. Este pórtico é o mesmo utilizado como reação nas provas de carga estática.

O conjunto só foi montado sobre o primeiro cilindro, pois ao se constatar que não havia nenhum deslocamento deste durante a injeção optou-se por não mover o pórtico para o cilindro seguinte, o que economizou muitas horas de trabalho e reduziu os custos (menos horas de aluguel de caminhão tipo munk e de pessoal).

Antes de cada injeção, uma barra de ferro com 2,3 m de comprimento era inserida no tubo e o cap posicionado na base era quebrado com o auxílio de uma marreta. Após a injeção, o tubo era fechado com um cap metálico rosqueável. Em seguida, era injetado o tubo diametralmente oposto e era possível perceber que as injeções se uniam sob a base do cilindro, pois ocorriam pequenos vazamentos de calda no tubo fechado. A Figura 4.8 mostra a sequência de execução das injeções e a Tabela 4.1 o consumo de cimento por cilindro. O critério de parada estabelecido para as injeções foi o volume injetado, com consumo de $140 \mathrm{~kg}$ de cimento. Nos cilindros 4 e 9 não foi possível injetar todo o volume pretendido devido a entupimentos na tubulação, que provocavam aumento de pressão. 
Foi observado que a calda entrava em contato com grande parte da área da base do cilindro, porem não havia deslocamento deste, pois o solo não oferecia a reação necessária.

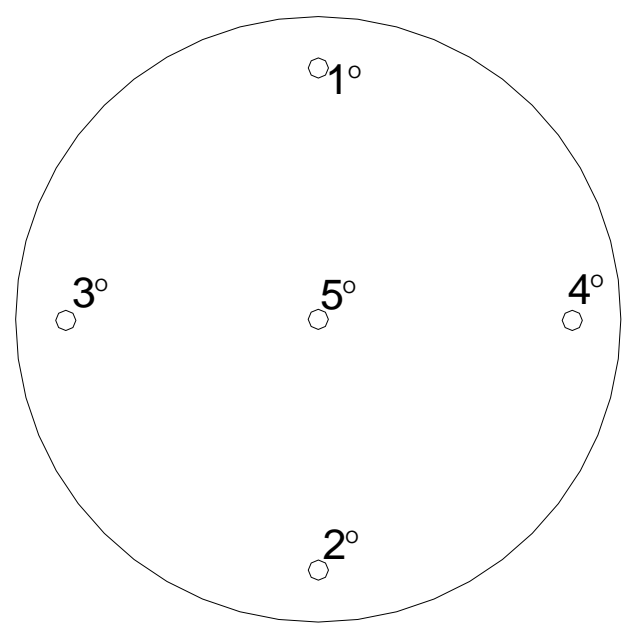

Figura 4.8 - Ordem de execução das injeções nos 5 furos de cada cilindro de concreto

Tabela 4.1 - Consumo de cimento das bases injetadas

\begin{tabular}{|c|c|}
\hline Cilindro & Consumo $(\mathrm{kg})$ \\
\hline 4 & 120 \\
\hline 9 & 140 \\
\hline 7 & 100 \\
\hline 8 & 140 \\
\hline
\end{tabular}

Na Tabela 4.2 são mostradas as pressões finais de injeção por furo e a pressão máxima registrada durante a injeção. Dois furos ficaram pressurizados, mas o leitor não registrou a pressão (sem leitura - SL). Num dos furos do cilindro 9 a pressão chegava a 500 $\mathrm{kPa}$, porém caía rapidamente, chegando a zero em poucos segundos. O mesmo aconteceu num dos furos do cilindro 8, que registrou pico de pressão de 590 kPa neste mesmo furo. 
Tabela 4.2 - Pressões de injeção finais e máxima para cada cilindro de concreto

\begin{tabular}{|c|r|r|r|r|r|r|}
\hline $\begin{array}{c}\text { (pressões em } \\
\text { kPa) }\end{array}$ & $\begin{array}{c}\text { borda } \\
1\end{array}$ & $\begin{array}{c}\text { borda } \\
4\end{array}$ & $\begin{array}{c}\text { borda } \\
2\end{array}$ & $\begin{array}{c}\text { borda } \\
3\end{array}$ & central & $\begin{array}{r}\text { pressão } \\
\text { máxima }\end{array}$ \\
\hline cilindro 4 & 240 & 130 & 230 & 120 & 210 & 700 \\
\hline cilindro 9 & 270 & 600 & 690 & 0 & \multicolumn{1}{c}{$\mathrm{SL}$} & 700 \\
\hline cilindro 7 & 350 & 320 & 520 & 350 & 120 & 890 \\
\hline cilindro 8 & 0 & 420 & 180 & \multicolumn{1}{c|}{$\mathrm{SL}$} & 170 & 810 \\
\hline
\end{tabular}

\subsection{EXECUÇÃO DAS ESTACAS}

Em duas etapas, foram executadas cinco estacas com diâmetro de fuste igual a 0,60 $\mathrm{m}$ e comprimento igual a $8 \mathrm{~m}$, sendo duas estacas na primeira etapa e três na segunda. $\mathrm{Na}$ armadura de cada estaca (Figura 4.9) foram colocados cinco tubos de PVC com comprimento igual a $8,5 \mathrm{~m}$ e bitola de 1", sendo quatro tubos amarrados nas ferragens principais e um tubo amarrado no centro (Figura 4.10). Para reduzir os custos, foi utilizado PVC especial (para água quente) somente na parte que ficaria exposta, e esse foi ligado ao PVC comum que foi concretado com o fuste. Os conjuntos armaduras mais tubos foram colocados em cinco cavas escavadas com o auxílio de uma perfuratriz, com 8,5 m de comprimento e diâmetro igual a 0,60 m (Figura 4.11). A armação das estacas é a mesma de tubulões com e sem bases alargadas executados em pesquisas anteriores.

As armaduras foram posicionadas com o auxílio de um caminhão munk e a disposição final pode ser vista na Figura 4.12. Anteriormente à concretagem, $70 \mathrm{~cm}$ de altura de solo solto foi jogado nas cavas, a fim de evitar contaminação da ponta dos tubos pelo concreto, com o auxílio de uma marcação feita nos tubos de PVC. Para verificar se já havia sido colocado solo o suficiente era necessário iluminar o fundo do furo com uma lâmpada ligada a um fio de comprimento igual a $8 \mathrm{~m}$. A marcação nos tubos foi feita com pedaços de fita isolante preta e isso dificultava a visualização, pois eram confundidos com as sombras. A utilização de cor contrastante teria facilitado o trabalho. Além da proteção de solo, as bases dos tubos foram protegidas com preservativos de latex. 


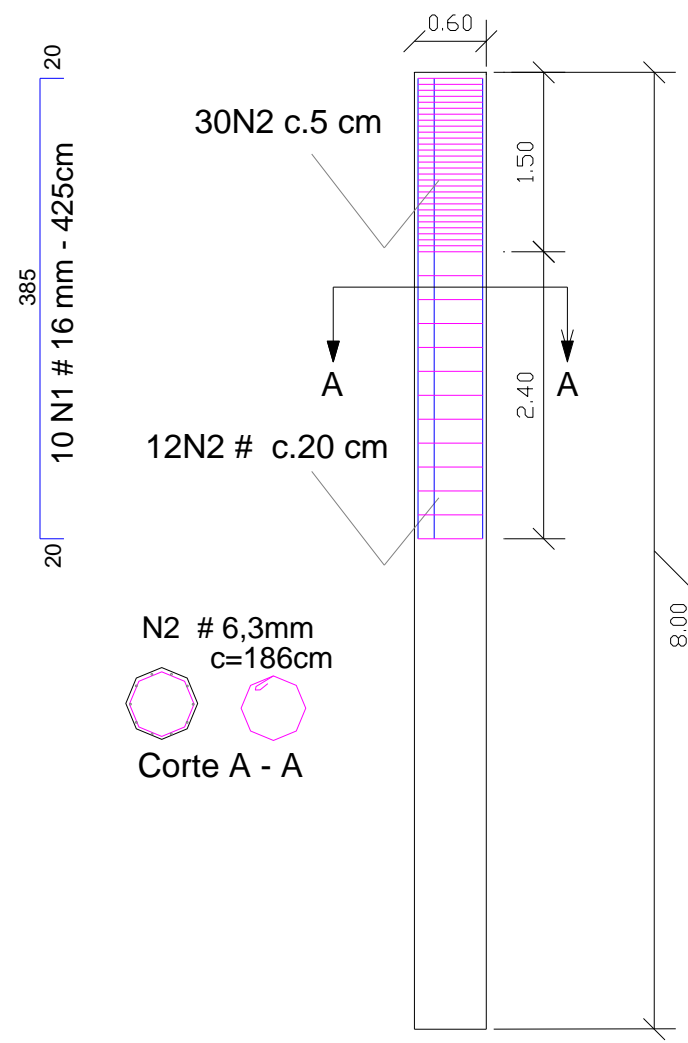

Figura 4.9 - Armação das estacas

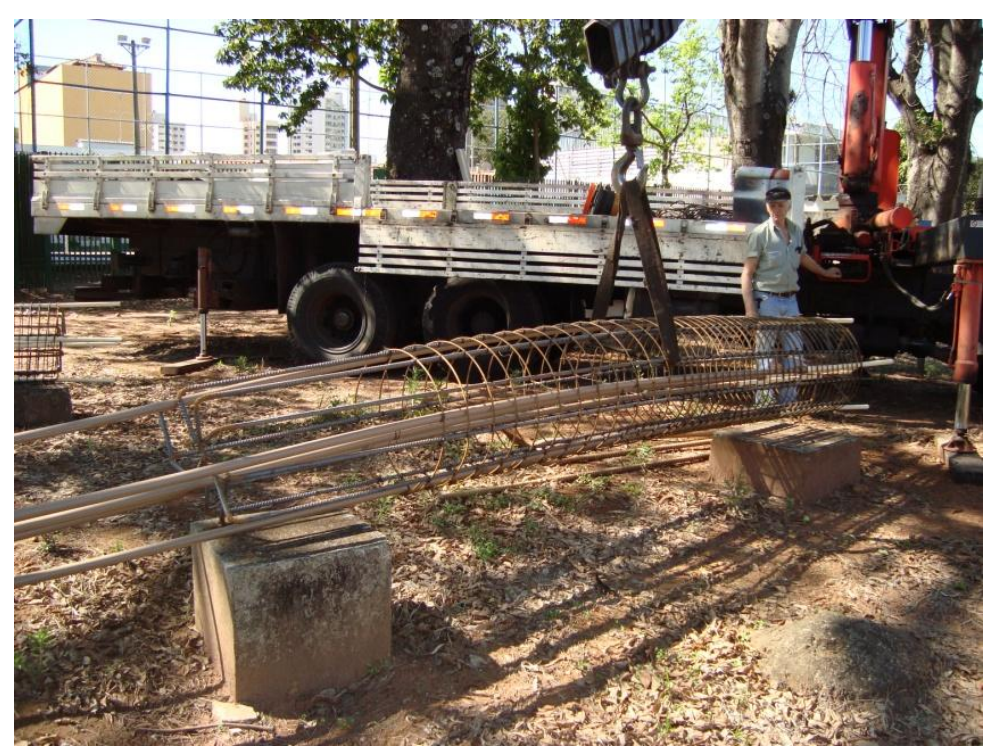

Figura 4.10 - Armação das estacas com tubos de PVC 


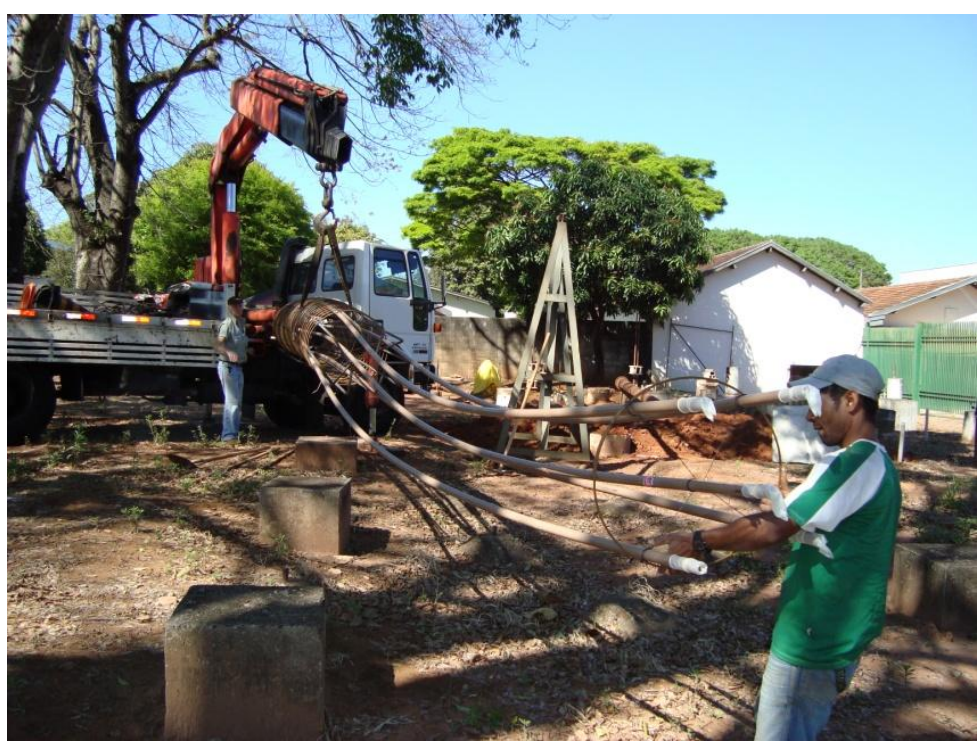

Figura 4.11 - Armação das estacas com tubo de PVC comum

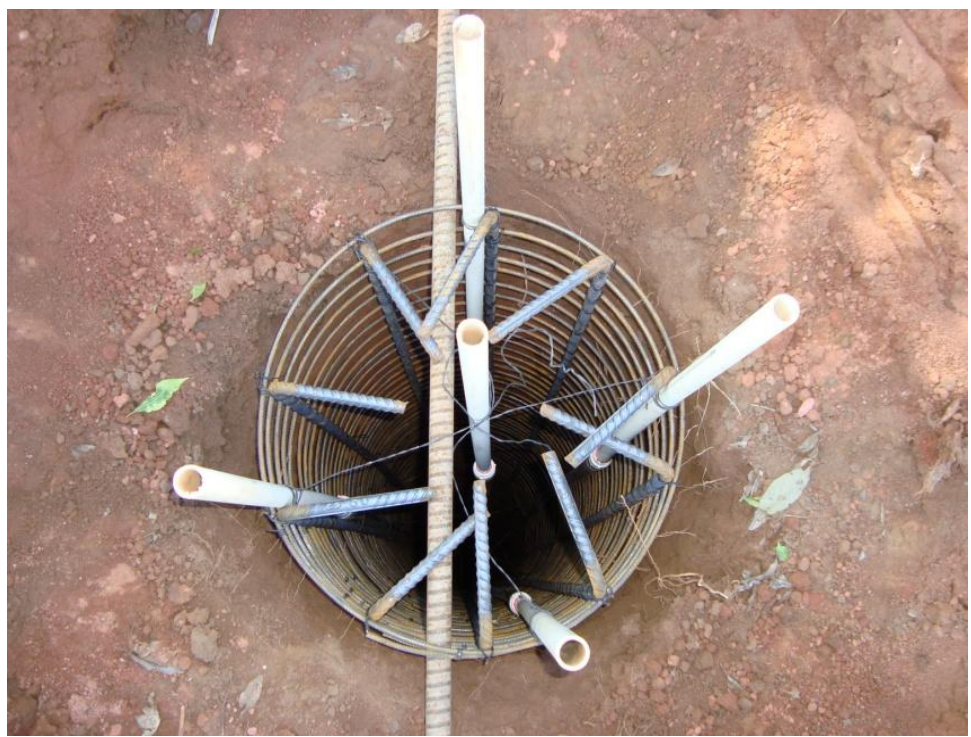

Figura 4.12 - Armação das estacas posicionada na cava com PVC especial nas pontas

Em seguida, as estacas foram concretadas, utilizando-se concreto usinado com fck igual a $30 \mathrm{MPa}$. Durante a concretagem, o concreto foi vibrado utilizando-se um vibrador de imersão (mangote). 
Uma semana antes das injeções, os caps que protegiam as cabeças dos tubos foram substituídos por conectores de PVC com rosca metálica. Os conectores foram colados com adesivo especial para PVC de alta pressão. O sistema injetor montado era rosqueado ao conector utilizando-se uma união.

\subsection{EXECUÇÃO DAS INJEÇÕES DAS ESTACAS}

Após a cura do concreto das estacas, deu-se início a etapa de injeções. O sistema injetor utilizado foi o mesmo montado para as injeções das bases dos cilindros, com uma diferença: optou-se por utilizar um manômetro analógico para leitura da pressão de injeção em vez do transdutor digital. O manômetro tinha um fundo de escala maior, $1.200 \mathrm{kPa}$ contra $1.000 \mathrm{kPa}$ do digital. O sistema pode ser visto nas Figuras 4.13 a 4.15 .

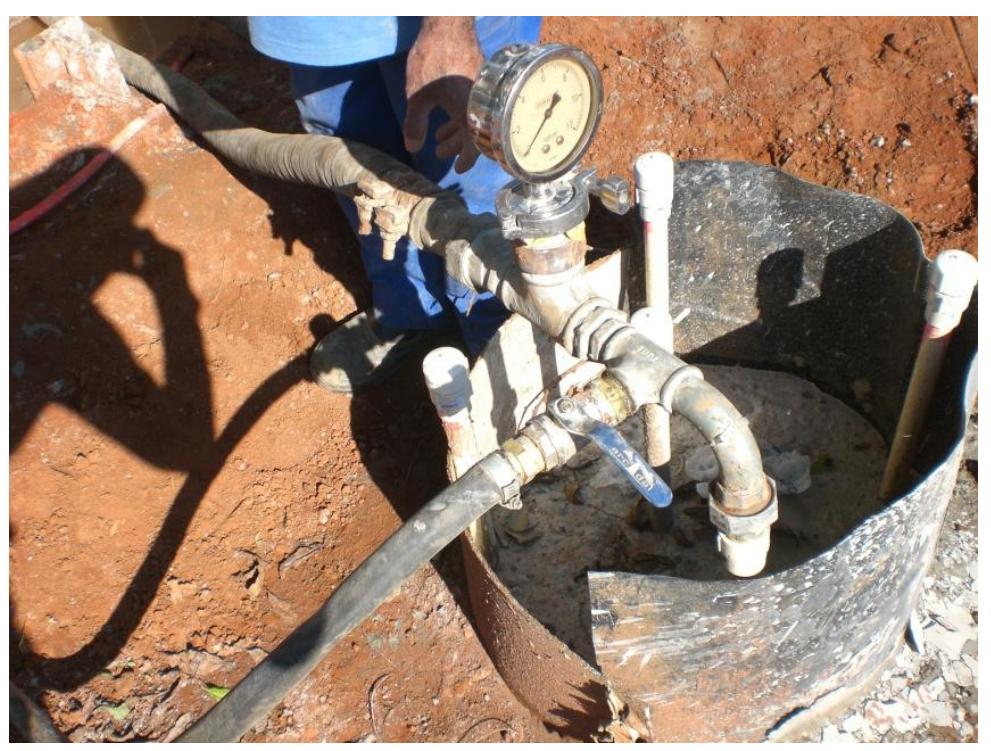

Figura 4.13 - Execução da injeção 
Para pressurizar a calda de cimento foi utilizada uma bomba de pistão, elétrica trifásica, com potência igual a 7,5 HP, a mesma utilizada para os cilindros (Figura 4.14). Para alimentar a bomba foi utilizada uma argamasseira (Figura 4.15), pois o volume de calda injetada impedia o uso da betoneira de propriedade do departamento de geotecnia. A calda, com fator água/cimento igual a 0,55, era misturada e a agitação era mantida utilizando-se a argamasseira.

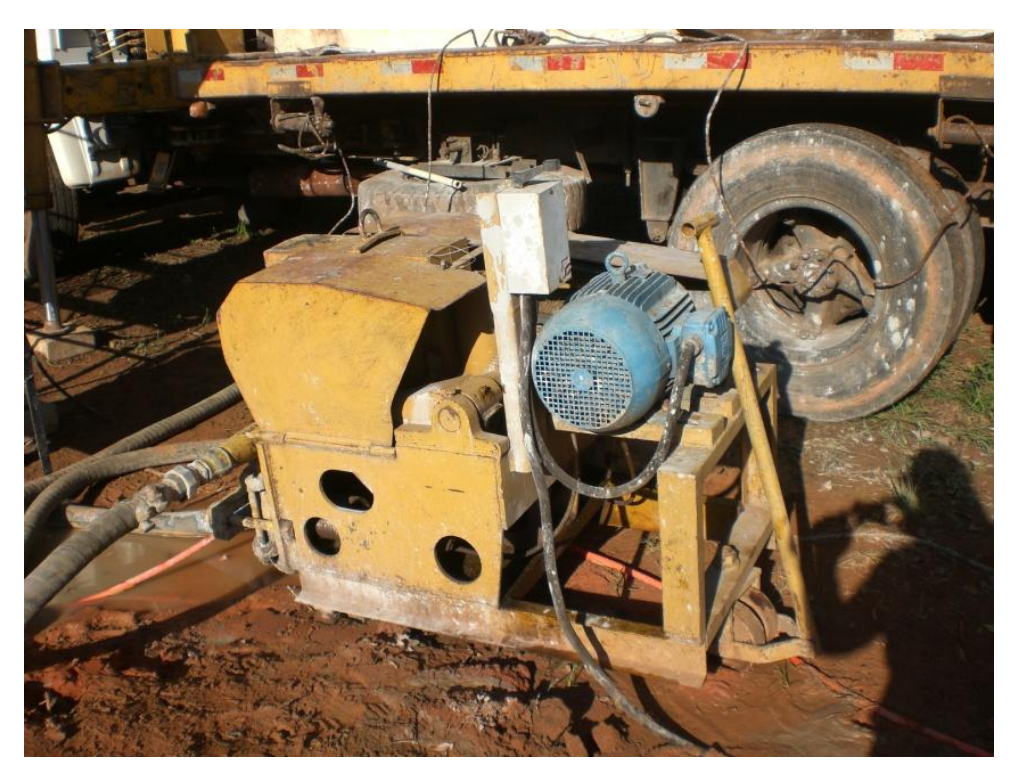

Figura 4.14 - Bomba de pistão 


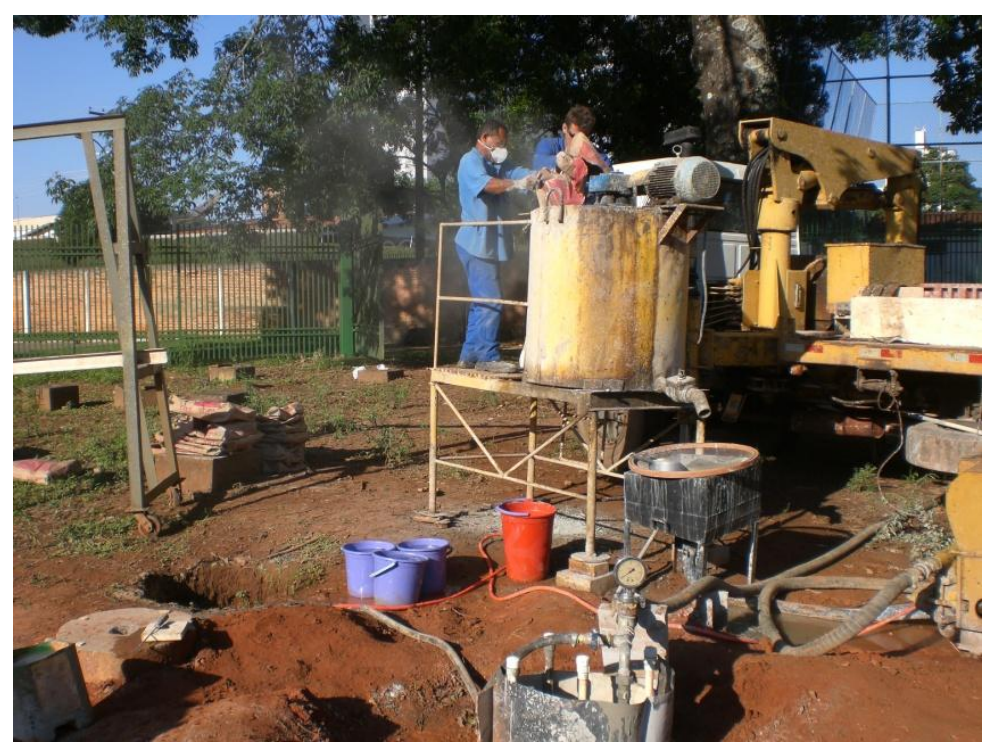

Figura 4.15 - Argamasseira e sistema injetor

Os preservativos de látex colocados nos tubos funcionaram como válvulas. Eles foram cortados na ponta de forma que ainda impedissem a entrada de solo no tubo e permitissem a saída de calda (Figura 4.16). Após a injeção, o tubo era fechado com um cap rosqueável. Em seguida, era injetado o tubo diametralmente oposto e era possível perceber que as injeções se uniam sob a base da estaca, pois ocorriam pequenos vazamentos de calda no tubo fechado. As Tabelas 4.3 e 4.4 mostram o consumo de cimento por estaca e as pressões finais e máximas registradas durante a injeção. 


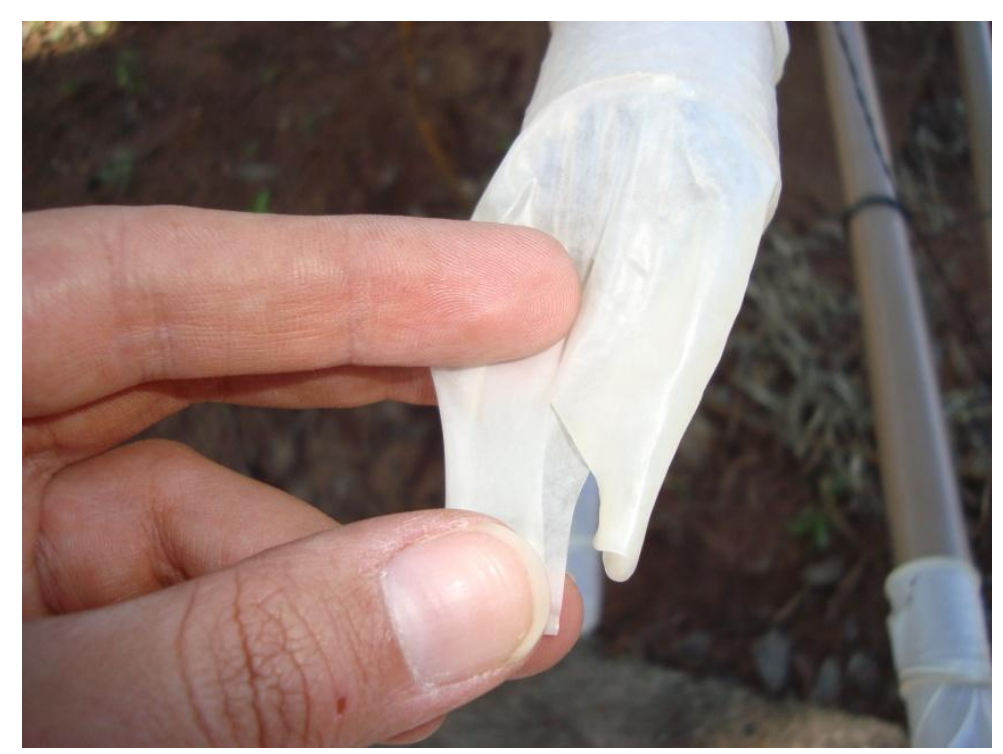

Figura 4.16 - "Válvula" de preservativo

Tabela 4.3 - Consumo de cimento na injeção por estaca

\begin{tabular}{|c|c|}
\hline Estaca & Consumo $(\mathrm{kg})$ \\
\hline A & 575 \\
\hline B & 750 \\
\hline C & 1400 \\
\hline D & 1400 \\
\hline E & 1400 \\
\hline
\end{tabular}

Tabela 4.4 - Pressões de injeção finais e máximas atingidas durante as injeções para cada estaca

\begin{tabular}{|c|r|r|r|r|r|r|}
\hline $\begin{array}{c}\text { (pressões em } \\
\text { KPa) }\end{array}$ & $\begin{array}{c}\text { borda } \\
1\end{array}$ & $\begin{array}{c}\text { borda } \\
4\end{array}$ & $\begin{array}{c}\text { borda } \\
2\end{array}$ & $\begin{array}{c}\text { borda } \\
3\end{array}$ & central & $\begin{array}{r}\text { pressão } \\
\text { máxima }\end{array}$ \\
\hline estaca A & 1200 & 0 & 1200 & 900 & 1000 & 1200 \\
\hline estaca B & 0 & 150 & 100 & 100 & 100 & 400 \\
\hline estaca C & 100 & 200 & 180 & 100 & 150 & 500 \\
\hline estaca D & 150 & 170 & 180 & 180 & 180 & 300 \\
\hline estaca E & 100 & 200 & 200 & 50 & 120 & 250 \\
\hline
\end{tabular}


A estaca A registrou pressões muito maiores devido a entupimentos ocorridos durante a injeção, que teve que ser paralisada diversas vezes para remoção do cimento entupido e foi interrompida antes de se completar o volume previsto. O problema foi resolvido na estaca B adotando-se uma medida muito simples: na saída da argamasseira foi colocada uma peneira, que impedia que pelotas (grumos) de cimento fossem bombeadas para os tubos de PVC (Figuras 4.17 e 4.18). Com a colocação da peneira, não foi necessário interromper a injeção da estaca B nenhuma vez. A injeção em cada tubo foi completada em poucos minutos e todo o volume de calda previsto foi injetado. O mesmo ocorreu nas injeções das estacas C, D e E, executadas em outra etapa, sob as mesmas condições das estacas A e B. Para as estacas A e B, o volume de injeção pretendido era igual a $1 \mathrm{~m}^{3}$, que equivale ao volume de concreto das bases de 1,5 m de tubulões executados no campo experimental. Para as estacas C, D e E, foram injetados $2 \mathrm{~m}^{3}$, que equivale a uma esfera de 1,5 m de diâmetro.

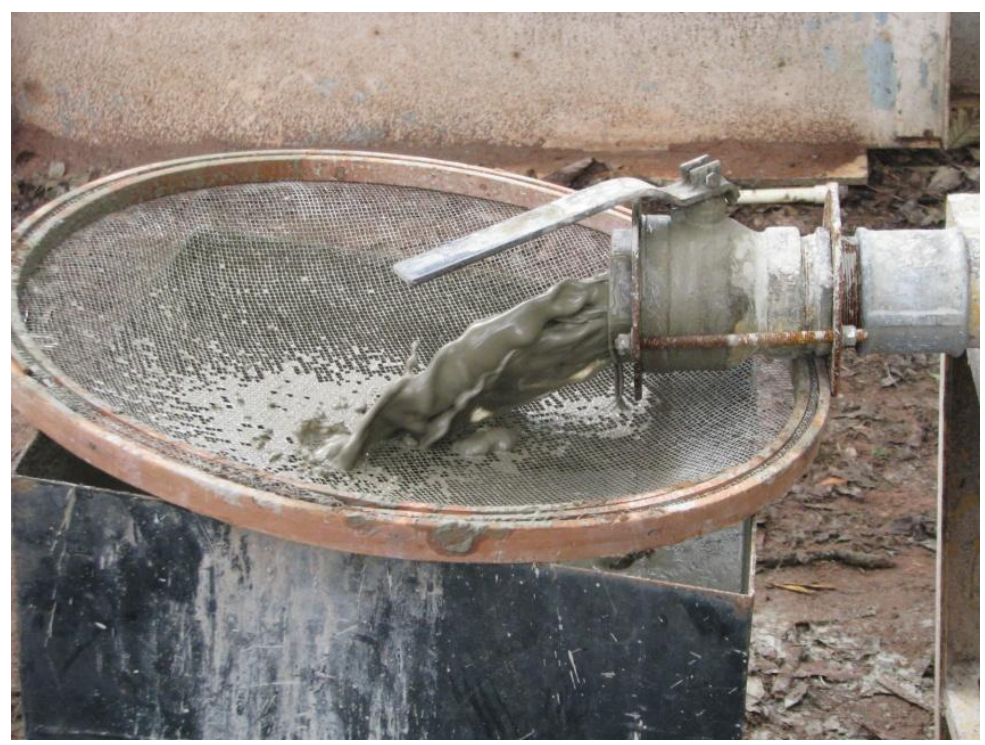

Figura 4.17 - Peneira na saída da argamasseira 


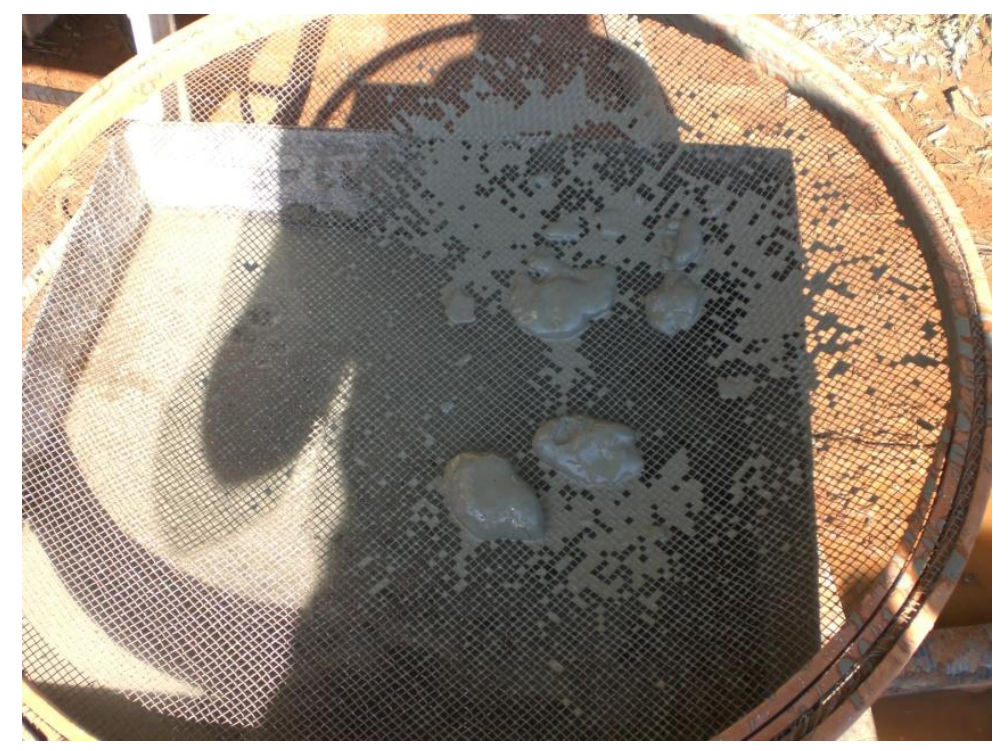

Figura 4.18 - "Grumos" de cimento

\subsection{PROVAS DE CARGA}

\subsubsection{BASES INJETADAS}

Como o objetivo da primeira etapa era ensaiar somente as bases injetadas, todo o solo ao redor dos cilindros de concreto foi removido, eliminando-se o atrito lateral (Figura 4.19).

Foram então realizadas quatro provas de carga estática nas bases injetadas 4, 7, 8 e 9, executadas sob os cilindros com mesma numeração. 


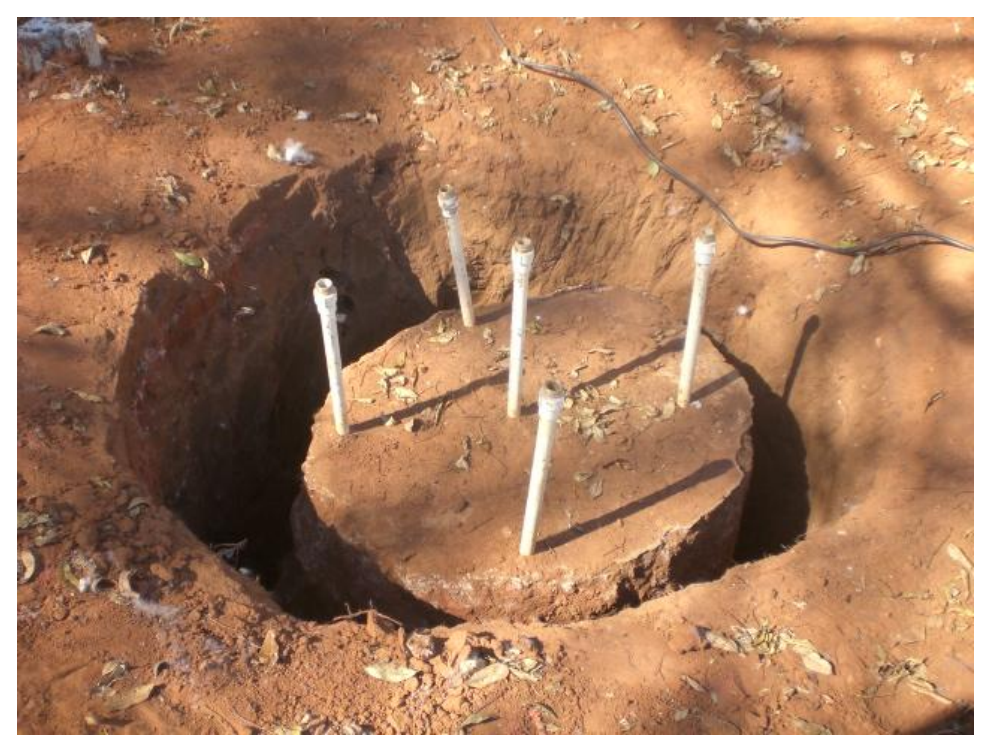

Figura 4.19 - Cilindro de concreto após remoção do solo lateral

Em dois ensaios o terreno foi pré-inundado por 48 horas mantendo-se sempre uma lâmina d'água de pelo menos 0,50 m no fundo da cava. Durante os ensaios a lâmina foi mantida.

As provas de carga estática foram realizadas com carregamento do tipo rápido (QML - Quick Maintained Load) de acordo com a NBR 12131/91, porém com estágios de 15 minutos de duração, segundo a proposição de Fellenius (1975). Durante cada estágio a carga era mantida e as leituras de recalque eram obtidas nos tempos de 0, 1, 3, 7 e 15 min.; - descarregamento foi realizado em três estágios de 15 minutos. Antes do descarregamento, deixou-se de repor a carga até a estabilização da carga e dos recalques.

Outras provas de carga estática, porém em placa, haviam sido realizadas por Costa (1999) e Moraes (2005) nas mesmas cavas onde foram construídos os cilindros e as bases injetadas. Costa (1999) fez um ensaio com carregamento lento (SML - Slow Maintained Load), um com carregamento rápido e dois com carregamento misto (lento até a tensão admissível provável e rápido a partir dessa). Os ensaios realizados nas cavas estudadas na 
pesquisa atual foram todos com terreno previamente inundado. Costa (1999) também tem outras provas de carga estática em cavas próximas com diferentes níveis de sucção. Optouse por usar nas comparações com a atual pesquisa, dois ensaios realizados em condições mais parecidas com as provas de carga estática atuais. Um deles, ensaio rápido em terreno inundado (denominado QS1), feito na cava 8, foi usado nas comparações com as cavas 7 e 8, e o outro, ensaio rápido em terreno não inundado com sucção igual a $15 \mathrm{kPa}$ (denominado Q1), feito numa cava a 2,5 m da cava 9, foi usado nas comparações com as cavas 9 e 4. As provas de carga de Moraes (2005) foram feitas em condições similares às atuais: ensaios QML com sucção nas cavas 9 e 4 e QML inundados nas cavas 7 e 8.

Na Figura 4.20 é possível observar o pórtico de reação e os equipamentos utilizados nas provas de carga e a Figura 4.21 mostra a montagem dos equipamentos sobre o cilindro de concreto sem solo nas laterais.

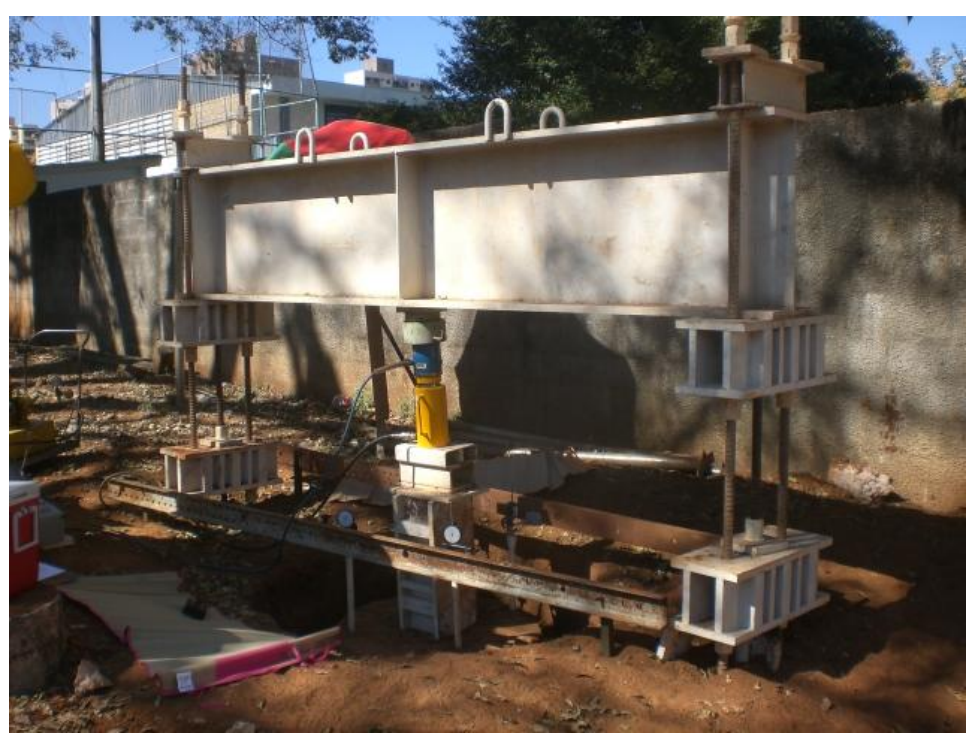

Figura 4.20 - Prova de carga estática 


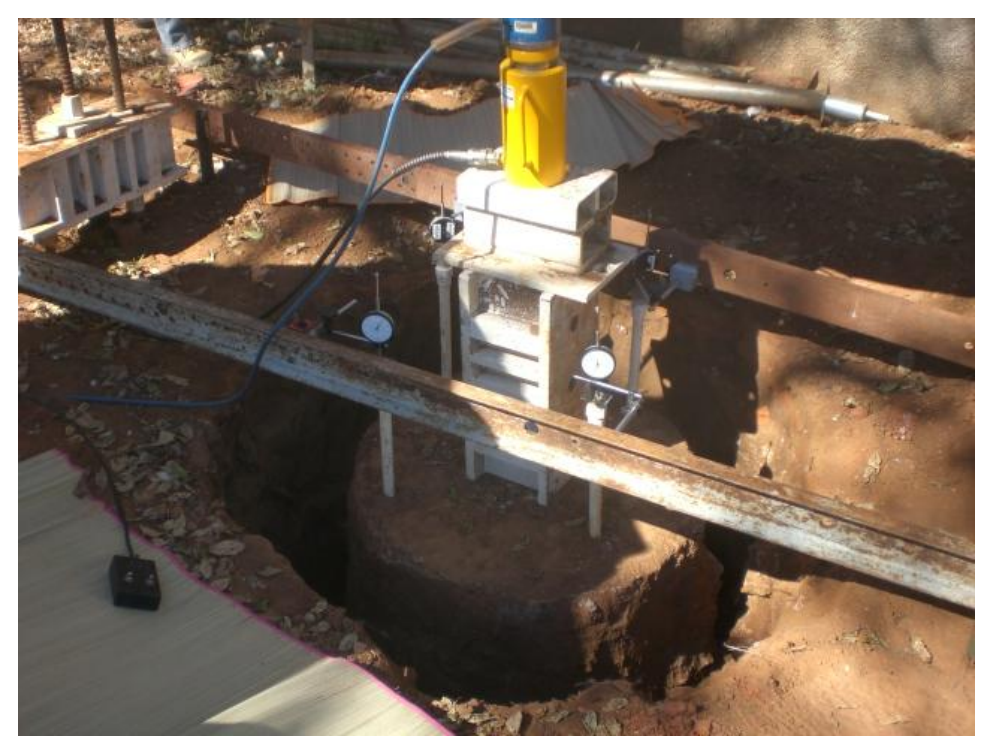

Figura 4.21 - Detalhe da prova de carga estática: cilindro de concreto com solo lateral removido

SUCÇÃO

Durante o período em que foram realizados os ensaios, leituras periódicas da sucção matricial foram feitas em tensiômetros instalados em uma cava de controle (Figura 4.22). Foram utilizados quatro tensiômetros acoplados a quatro vacuômetros. O tipo de tensiômetro usado tem um reservatório no topo (jet fill) que facilita a complementação do nível de água destilada no tubo, além de ajudar na remoção de bolhas de ar. 


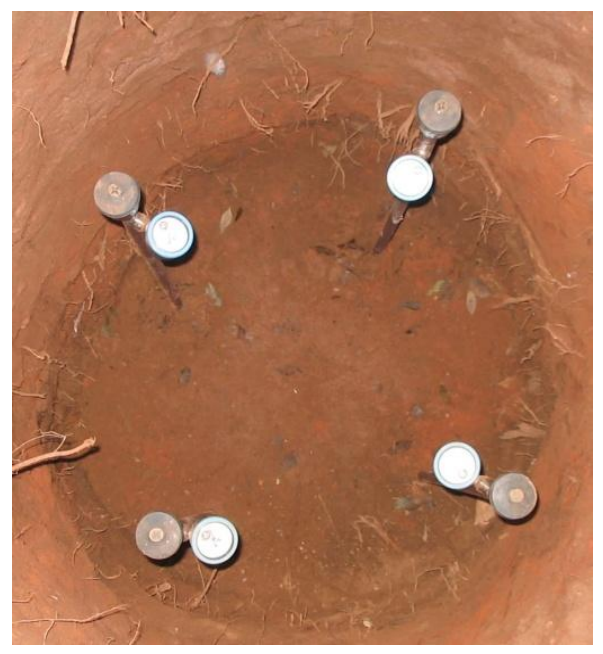

Figura 4.22 - Tensiômetros instalados na cava de controle.

Algumas características das provas de carga são mostradas nas Tabelas 4.5, 4.6 e 4.7.

Tabela 4.5 - Características das provas de carga

\begin{tabular}{|c|c|c|c|c|}
\hline $\begin{array}{c}\text { Base } \\
\text { injetada }\end{array}$ & Tipo de ensaio & Denominação & Sucção Matricial (kPa) & Pré-inundação \\
\hline 4 & QML & PCE4i & 20 & não \\
\hline 9 & QML & PCE9i & 20 & não \\
\hline 7 & QML & PCE7i & $\cong 0$ & sim \\
\hline 8 & QML & PCE8i & $\cong 0$ & sim \\
\hline
\end{tabular}

\subsubsection{ESTACAS}

Foram realizadas sete provas de carga estática nas estacas com base injetada. Os ensaios foram comparados com outras provas de carga feitas em pesquisas anteriores no mesmo campo experimental em quatro tubulões com base alargada de diâmetro igual a 1,5 $\mathrm{m}$ e dois tubulões sem bases alargadas. Todos os tubulões e estacas têm comprimento igual a $8 \mathrm{~m}$ e fuste com diâmetro igual a $0,60 \mathrm{~m}$.

Em três dos ensaios, o terreno foi pré-inundado por 48 horas mantendo-se sempre 
uma lâmina d'água de pelo menos $0,50 \mathrm{~m}$ no fundo da cava escavada ao redor do fuste (Figura 4.23). Durante os ensaios a lâmina foi mantida.

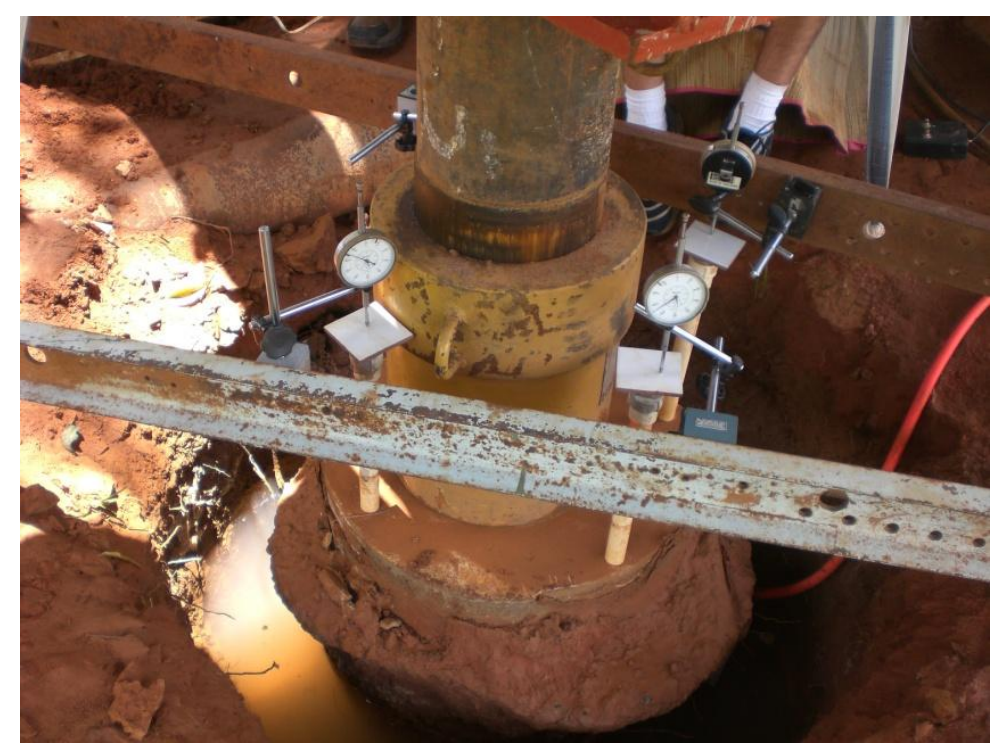

Figura 4.23 - Cava inundada

As provas de carga estática foram realizadas com carregamento do tipo lento (SML Slow Maintained Load) de acordo com a NBR 12131/91. Durante cada estágio a carga era mantida e as leituras de recalque eram obtidas nos tempos de $0,1,2,4,8,15$, e 30 min e, a partir daí, a cada hora até a estabilização dos recalques. O descarregamento foi realizado em três estágios de 15 minutos.

A sucção matricial foi medida através de um tensiômetro instalado a 0,70 m da superfície.

Algumas características das provas de carga são apresentadas na Tabela 4.6. 
Tabela 4.6 - Características das provas de carga

\begin{tabular}{|c|c|c|c|c|}
\hline Estaca & Tipo de ensaio & Denominação & Sucção Matricial (KPa) & Pré-inundação \\
\hline A & SML & EAi & $\cong 0$ & sim \\
\hline B & SML & EBi & $\cong 0$ & sim \\
\hline$B$ & SML & EB & 17 & não \\
\hline C & SML & EC & 16 & não \\
\hline D & SML & ED & 16 & não \\
\hline$E$ & SML & EE & 16 & não \\
\hline$E$ & $S M L$ & EEi & $\cong 0$ & sim \\
\hline
\end{tabular}

\subsubsection{EQUIPAMENTOS E MATERIAIS UTILIZADOS}

MACACOS HIDRÁULICOS E BOMBA

Para aplicação dos carregamentos, dois macacos hidráulicos foram utilizados. Um deles com capacidade de $2000 \mathrm{kN}$ nos ensaios em estacas e o segundo de $500 \mathrm{kN}$ para os ensaios nos cilindros. Para ambos, o acionamento era efetuado por uma bomba elétrica (Figura 4.24).

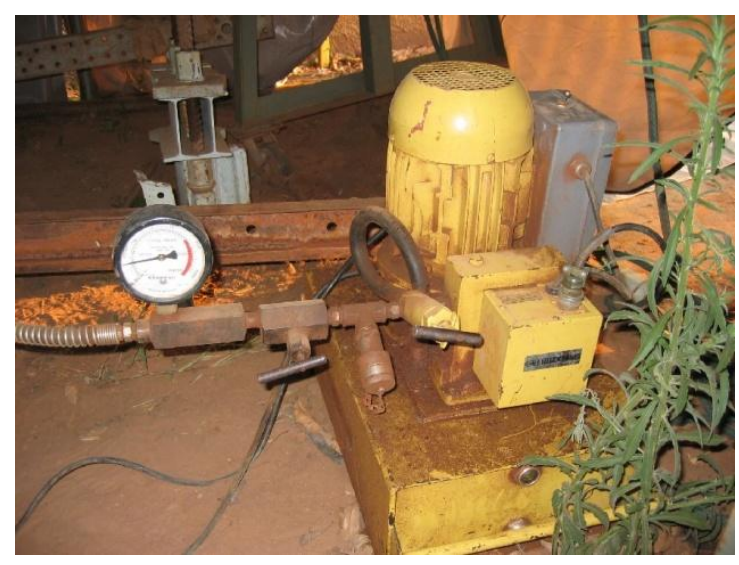

Figura 4.24 - Bomba hidráulica 
CÉLULA DE CARGA

Foi utilizada uma célula de carga da marca Alfa Instrumentos, com extensômetros elétricos de dupla ponte completa, com precisão de $0,3 \mathrm{kN}$ e capacidade para aplicação de 2000 kN. A Figura 4.25 mostra a célula de carga (azul) sobre o macaco hidráulico de 500 kN (amarelo).

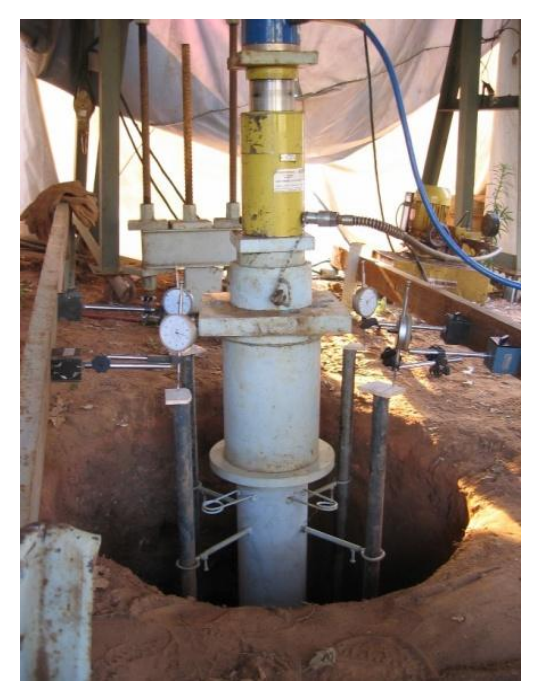

Figura 4.25 - Montagem da prova de carga estática

\section{INDICADOR DE DEFORMAÇÕES}

Para as leituras das deformações específicas dos strain-gauges instalados na célula de carga, foi usado um indicador de deformações da marca Transdutec, modelo T832, com resolução de $1 \mu$ strain e capacidade de leitura de $\pm 50000 \mu$ strain (Figura 4.26). 


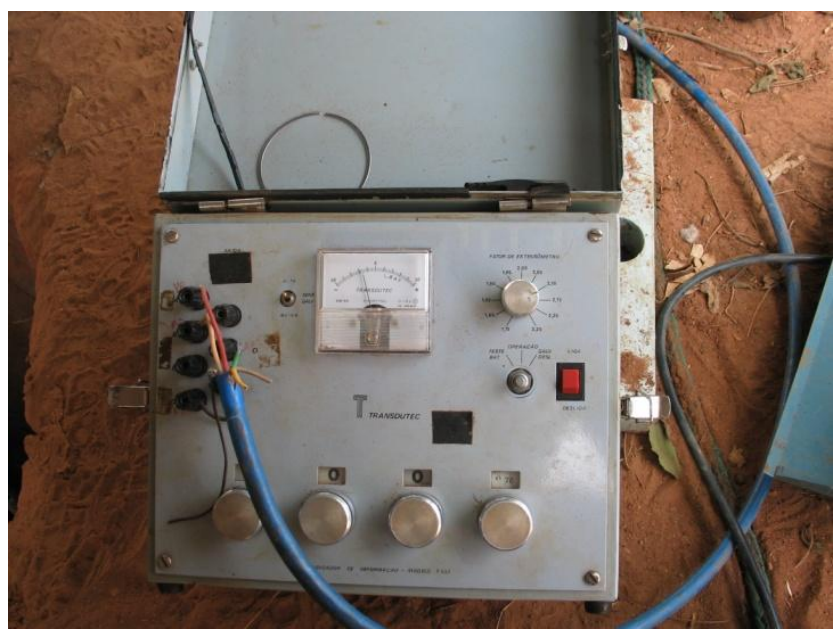

Figura 4.26 - Indicador de deformações

\section{EXTENSÔMETROS MECÂNICOS}

Para as leituras dos recalques foram usados quatro extensômetros da marca Mitutoyo, com resolução de $0,01 \mathrm{~mm}$ e curso total de $50 \mathrm{~mm}$. O extensômetros foram instalados com o auxílio de bases magnéticas articuláveis. Para ligar os extensômetros aos cilindros de concreto e às estacas, foram coladas nos quatro tubos de PVC externos (Figura 4.23) placas de vidro ou cerâmica, que forneceram superfícies bastante regulares e lisas, minimizando o atrito com a ponteira do extensômetro, e sofrem pouca variação de volume com a oscilação da temperatura.

\section{GUIAS DE REFERÊNCIA}

Como sistema de referência para medição dos recalques, foram utilizadas duas vigas de aço de $3,3 \mathrm{~m}$ de comprimento, cada uma parafusada a dois pontaletes de aço cravados no solo. Nas vigas, que são perfis $U$, foram fixadas as bases magnéticas dos extensômetros. 


\subsubsection{SISTEMAS DE REAÇÃO}

Foram utilizados três sistemas de reação. O primeiro (ensaios nos cilindros com base injetada) era formado por uma viga metálica, a qual transferia a carga aplicada pelo macaco a uma composição de barras do tipo Dywidag de $32 \mathrm{~mm}$ de diâmetro. As barras transmitiam a carga às estacas de reação (metálicas do tipo trilho TR-68, com 27 m de comprimento e carga admissível à tração de 550 kN).

A viga de reação utilizada possui seção transversal em I, com 300 x 650 mm, 3,30 m de comprimento e capacidade de suporte de $800 \mathrm{kN}$. Entre a célula de carga e a viga de reação foi utilizada uma rótula de aço para a conservação da normalidade do carregamento.

Para ensaiar as estacas foi necessário recorrer a dois outros arranjos, devido às cargas envolvidas e posição das reações existentes. Num deles utilizou-se o sistema anteriormente explicado, acrescido de um perfil I com $6 \mathrm{~m}$ de comprimento, instalado acima ou abaixo da primeira viga, perpendicular a ela, também por uma composição de barras Dywidag (Figura 4.27). As barras transmitiram as cargas para tubulões existentes no campo experimental. A ligação dos tubulões com os consolos metálicos e barras Dywidag foi feita através de estruturas metálicas construídas a partir de perfis I (152 × $90 \mathrm{~mm}$ ) e cantoneiras de abas iguais (101 mm), chumbadas às paredes dos tubulões por parabolts. A estrutura de ligação pode ser observada na Figura 4.28. 


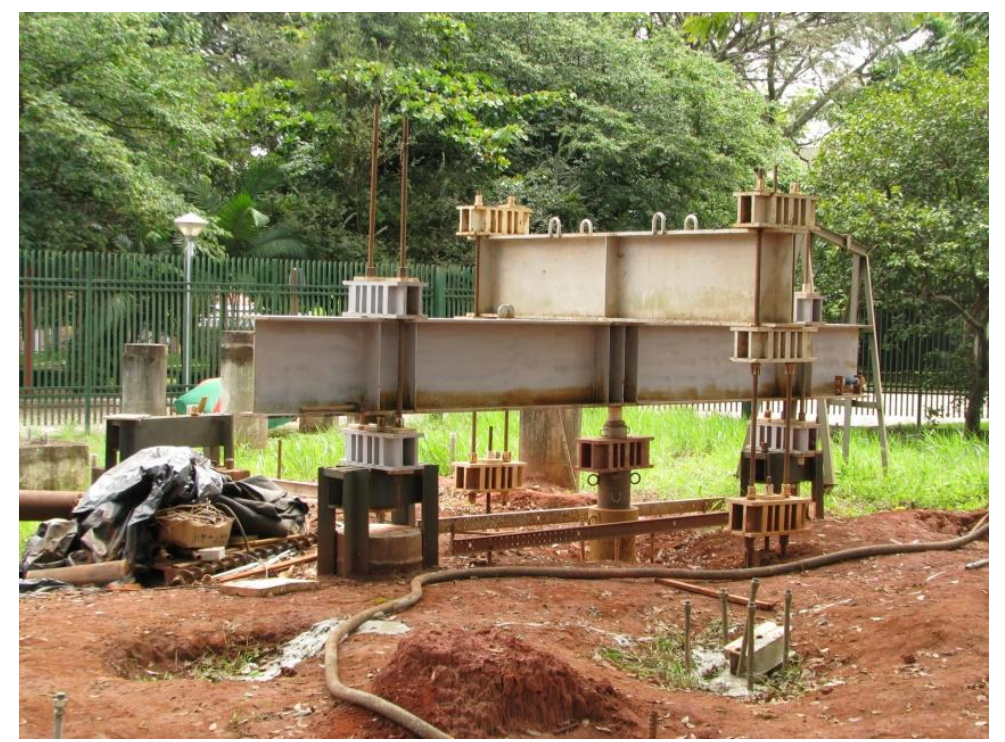

Figura 4.27 - Sistema de reação 2

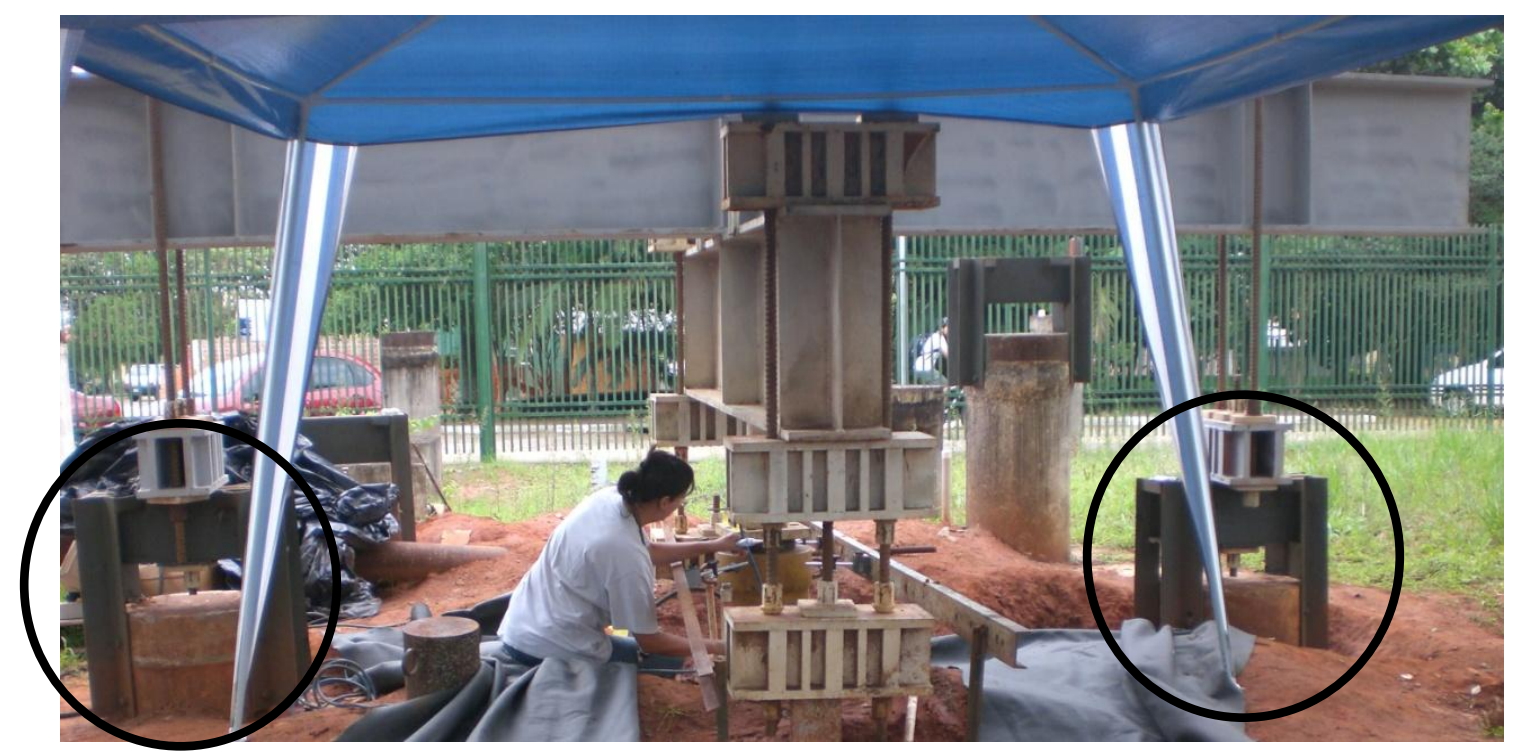

Figura 4.28 - Ligação dos tubulões com a viga de reação de $6 \mathrm{~m}$

O outro sistema de reação para ensaios das estacas era formado por um conjunto de quatro perfis I parafusados entre si, medindo 3,30 por 4,30 m. Os esforços foram transmitidos para estacas trilho e estacas escavadas, através de uma composição de barras Dywidag e consolos metálicos e pode ser vista na Figura 4.29. 


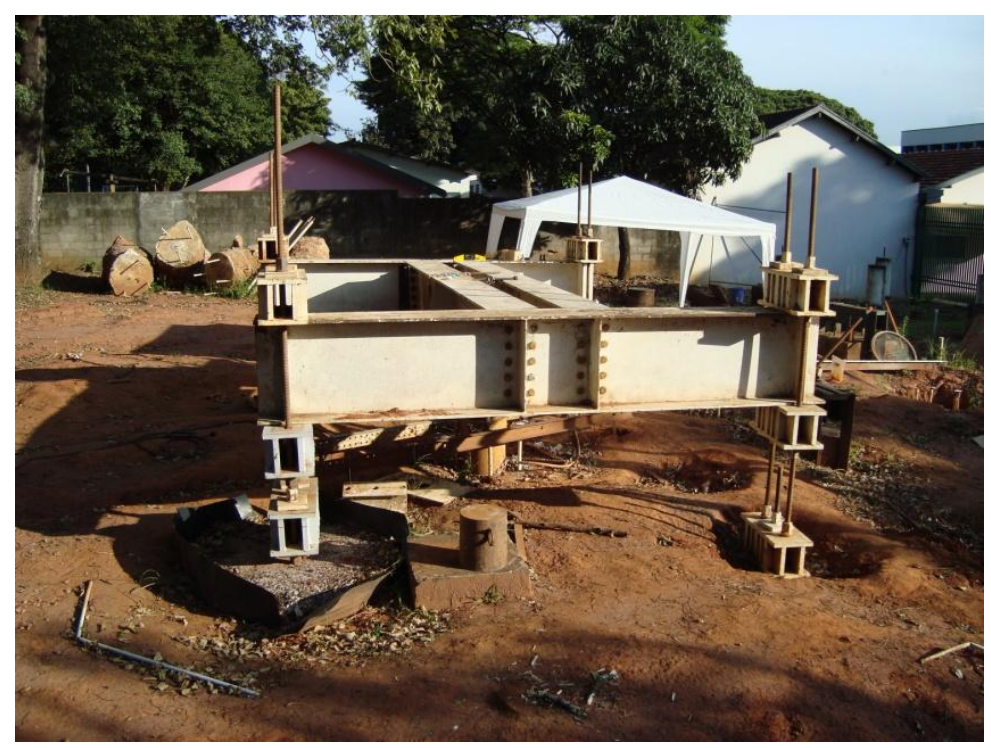

Figura 4.29 - Sistema de Reação 3

\subsection{EXTRAÇÃO DOS CILINDROS COM BASE INJETADA}

Após a retirada do solo lateral dos cilindros e antes da execução das provas de carga, foram realizados ensaios de campo utilizando um penetrômetro manual portátil da marca Solotest (ref. 1.210.001), para verificar a influência radial das injeções no solo sob a base dos cilindros. O aparelho não foi capaz de detectar mudanças na resistência do solo radialmente. O solo estava muito compactado e ficou além do limite do aparelho.

Após a realização das provas de carga nas bases injetadas e antes da execução das estacas da segunda etapa, os cilindros foram extraídos do solo para observação da distribuição da calda de cimento. Foi feita uma tentativa de extração utilizando-se o pórtico de reação da prova de carga juntamente com um macaco hidráulico para levantar o cilindro que seria retirado da cava com o auxílio do caminhão tipo munk (Figura 4.30), porém sem sucesso. Para a extração, foi necessário o uso de um guindaste, que pode ser visto nas Figuras 4.31 a 4.33 . 


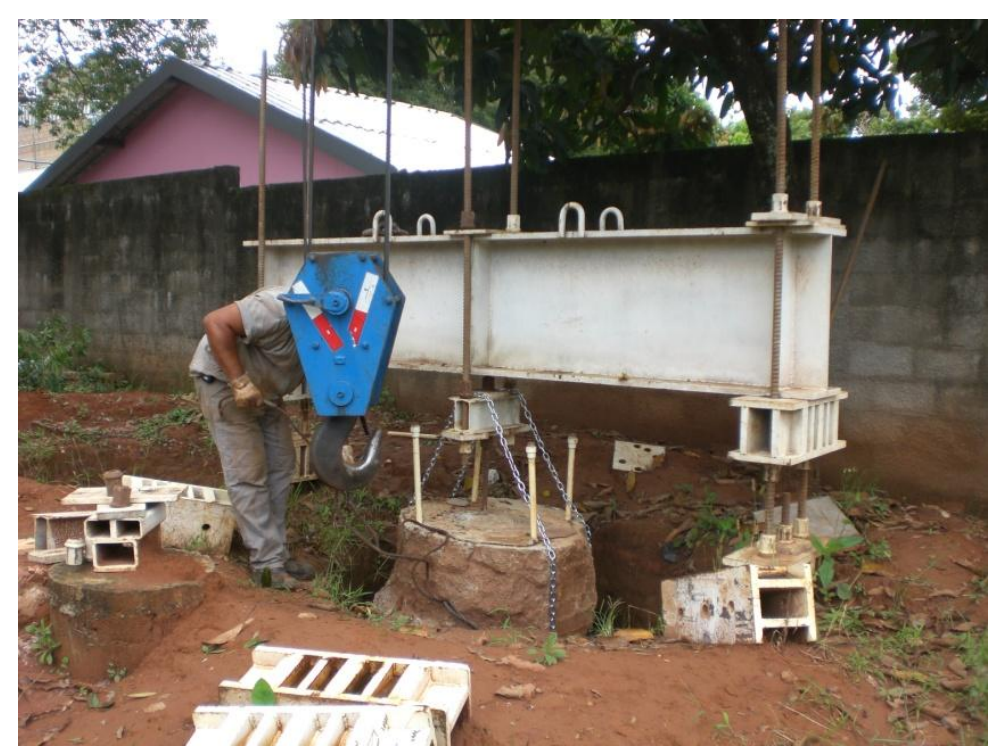

Figura 4.30 - Tentativa de extração com pórtico de reação

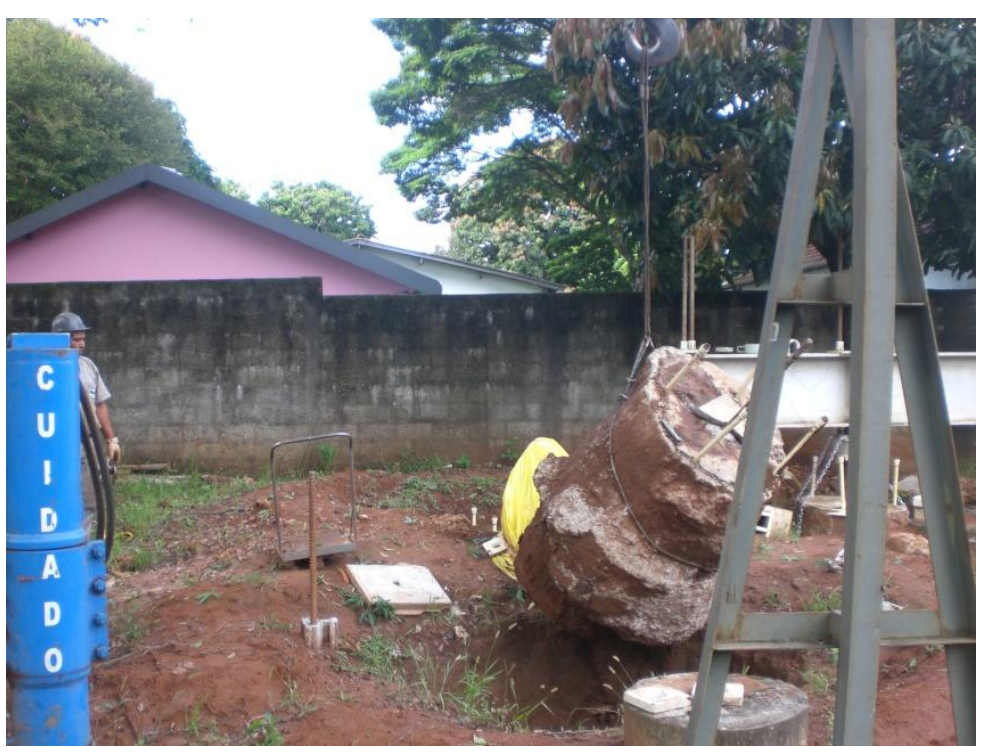

Figura 4.31 - Extração do cilindro com guindaste (a) 


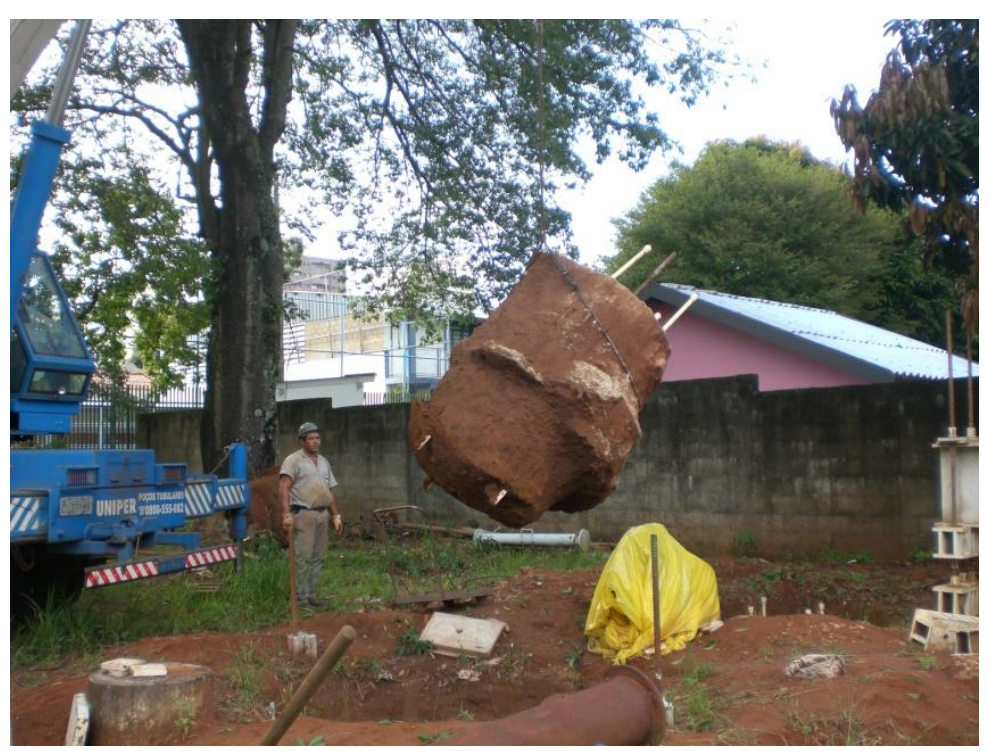

Figura 4.32 - Extração do cilindro com guindaste (b)

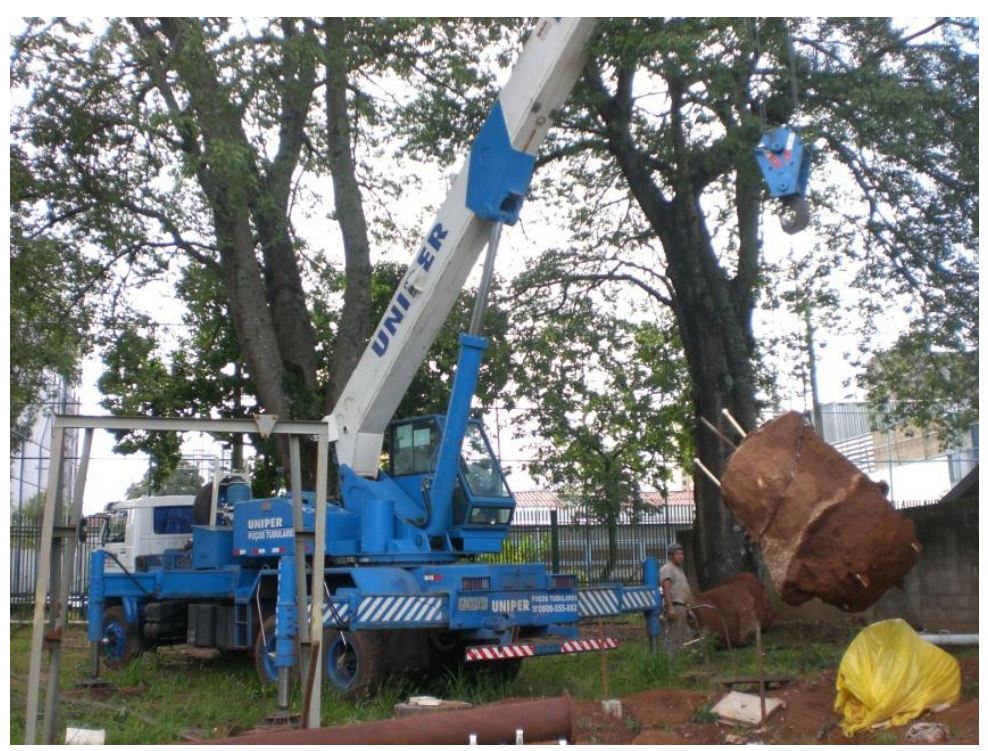

Figura 4.33 - Extração do cilindro com guindaste (c) 


\section{RESULTADOS}

A seguir são apresentados os resultados das quatro provas de carga estática nas bases injetadas sob os cilindros de concreto e sete nas estacas.

\subsection{PROVAS DE CARGA ESTÁTICA NAS BASES INJETADAS}

Os resultados das provas de carga estática nas bases injetadas executadas sob os cilindros de concreto são apresentados nas Figuras 5.1 a 5.4. Os cilindros têm comprimento igual a 1,80 m com 0,80 m de diâmetro. A Tabela 5.1 apresenta os volumes das bases injetadas.

Tabela 5.1 - Volume de calda das bases injetadas

\begin{tabular}{|c|c|}
\hline $\begin{array}{c}\text { Base } \\
\text { Injetada }\end{array}$ & Volume $\left(\mathrm{m}^{3}\right)$ \\
\hline 4 & 0,17 \\
\hline 9 & 0,2 \\
\hline 7 & 0,14 \\
\hline 8 & 0,2 \\
\hline
\end{tabular}

Antes da realização das provas de carga, todo o solo ao redor dos cilindros foi removido para que se pudesse ensaiar somente as bases injetadas. Os ensaios foram realizados com carregamento do tipo rápido e dois deles foram executados após inundação do terreno por $24 \mathrm{~h}$ (bases injetadas 7 e 8). Os outros ensaios foram realizados em terreno não inundado com medida de sucção matricial (bases injetadas 4 e 9). 


\section{Base Injetada 4}

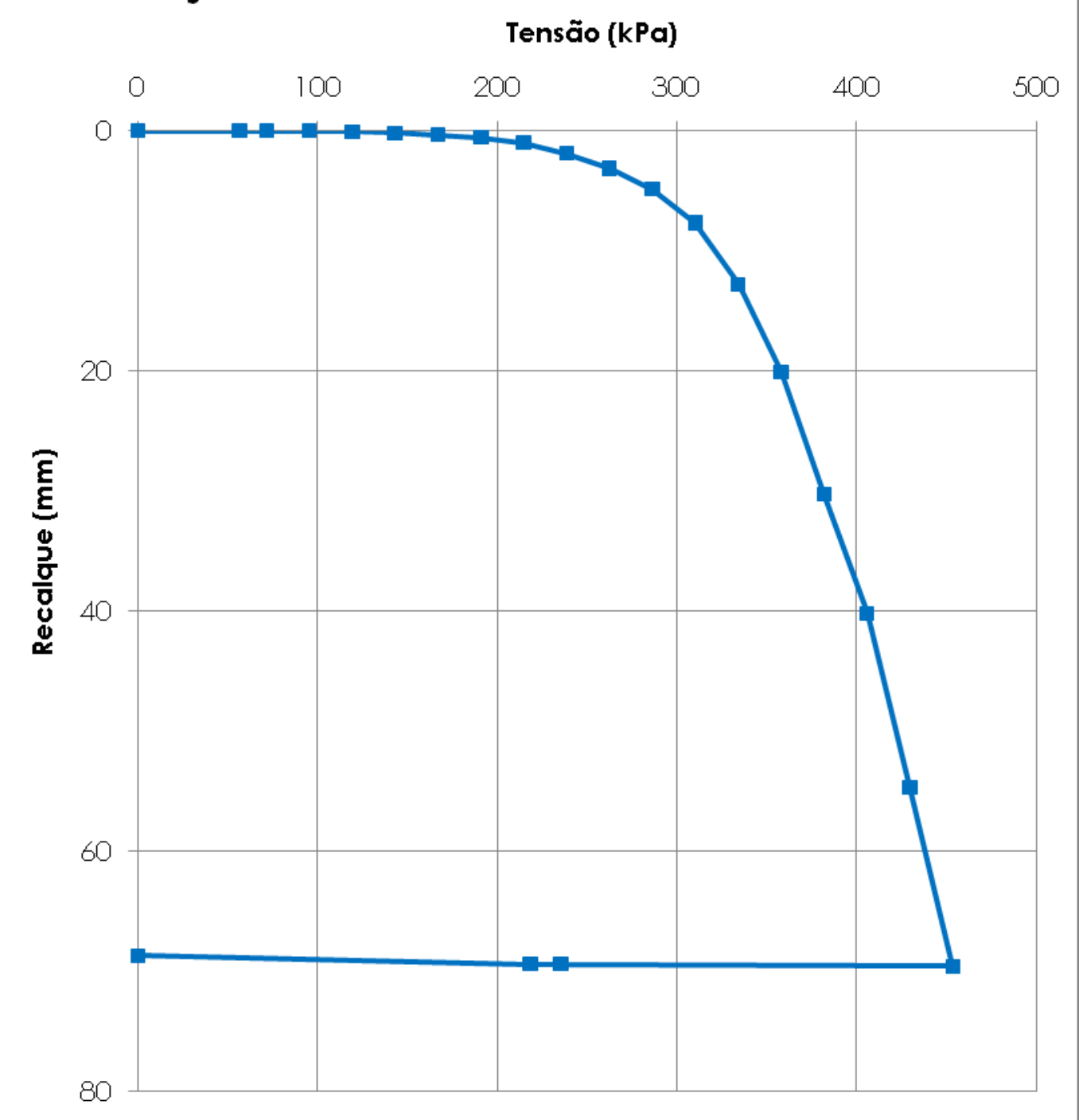

Figura 5.1 - Curva tensão x recalque (base injetada 4, terreno não inundado) 


\section{Base Injetada 9}

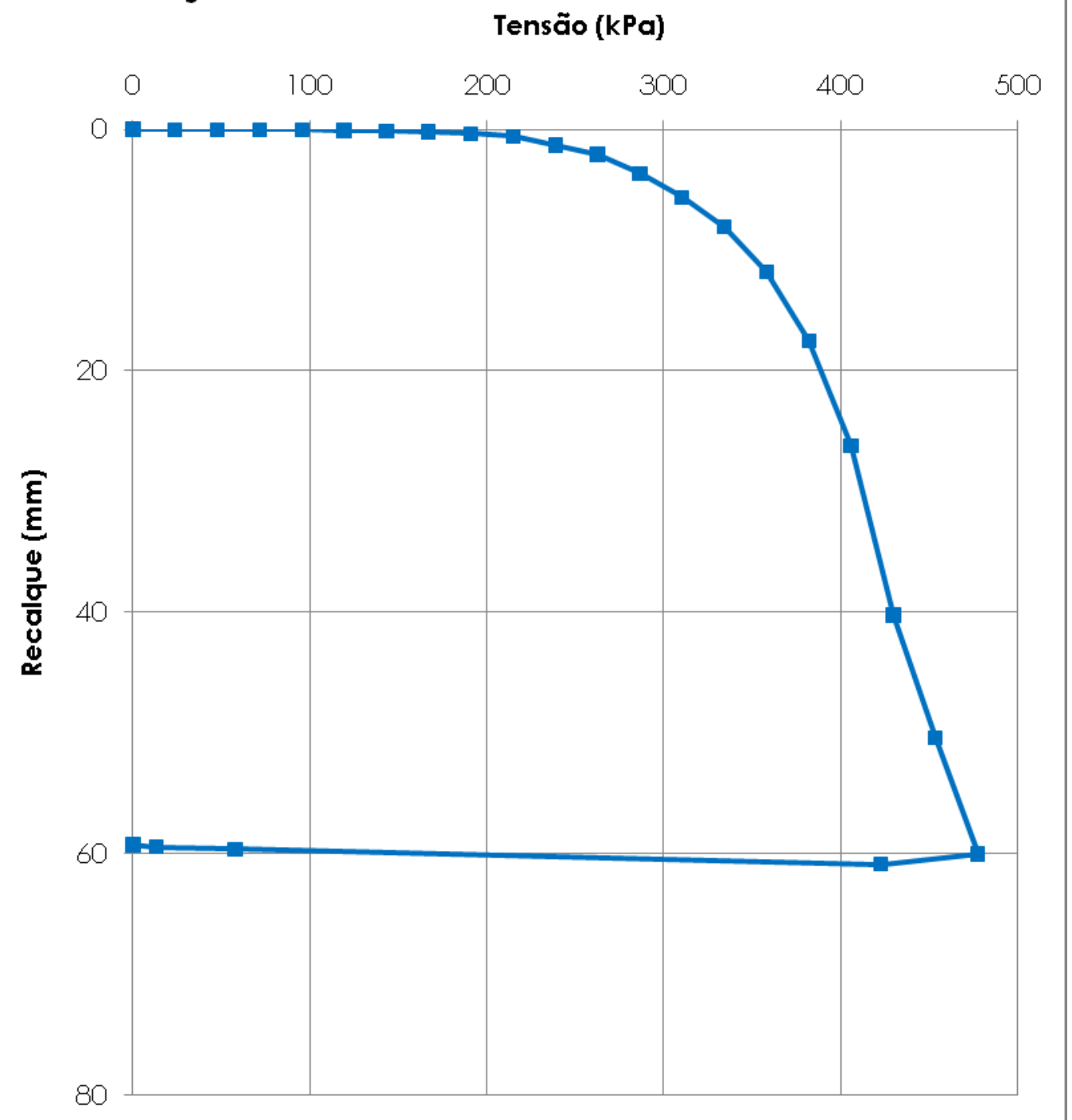

Figura 5.2 - Curva tensão x recalque (base injetada 9, terreno não inundado) 


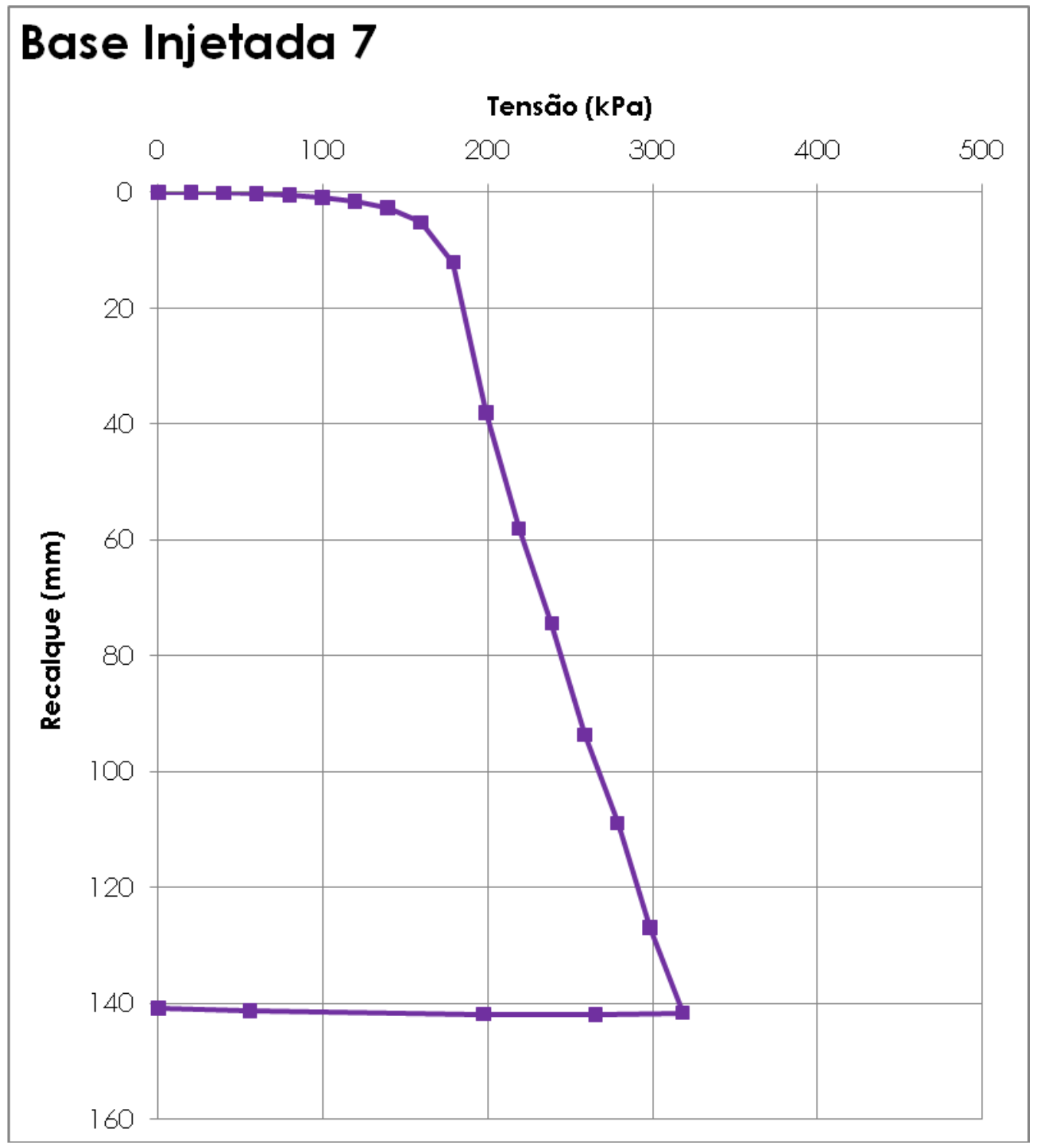

Figura 5.3 - Curva tensão x recalque (base injetada 7, terreno inundado) 


\section{Base Injetada 8}

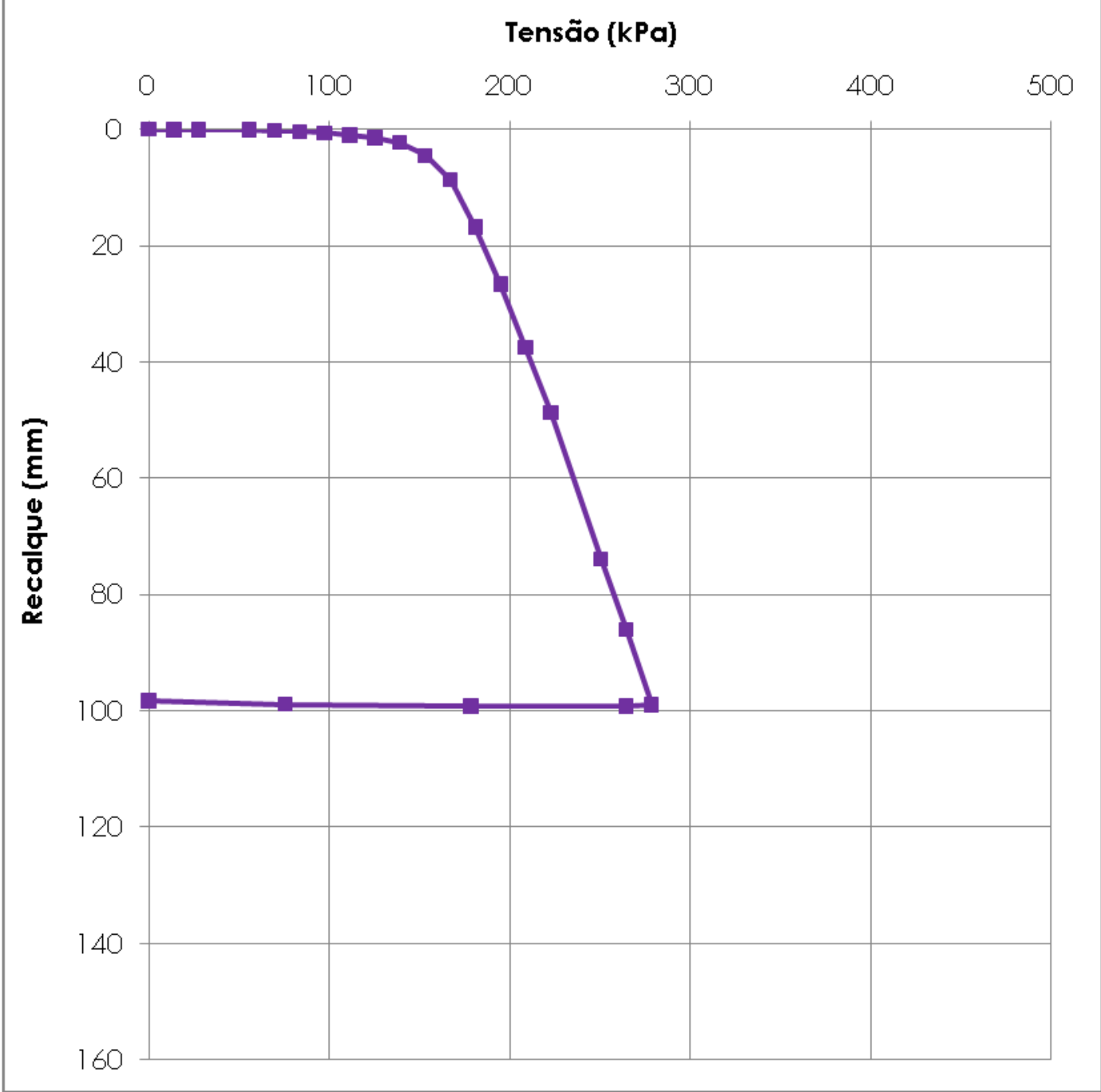

Figura 5.4 - Curva tensão x recalque (base injetada 8, terreno inundado) 


\subsection{PROVAS DE CARGA ESTÁtICA NAS ESTACAS}

Os resultados das provas de carga estática nas estacas A a E são apresentados nas Figuras 5.5 a 5.11. Os ensaios foram realizados com carregamento do tipo lento (SML) e três deles executados após inundação do terreno por 24 h, nas estacas A, B e E. Os outros ensaios foram realizados em terreno não inundado com medida de sucção matricial, nas estacas B, C, D e E. Algumas características das estacas são apresentadas na Tabela 5.2.

Tabela 5.2 - Características das estacas com base injetada

\begin{tabular}{|c|c|c|c|c|}
\hline Estaca & $\begin{array}{c}\text { Volume de } \\
\text { injeção }\left(\mathrm{m}^{3}\right)\end{array}$ & $\begin{array}{c}\text { Comprimento } \\
(\mathrm{m})\end{array}$ & $\begin{array}{c}\text { Diâmetro do } \\
\text { fuste }(\mathrm{m})\end{array}$ & Condição de inundação \\
\hline EA & 0,78 & 8 & 0,60 & inundado \\
\hline EB & 1 & 8 & 0,60 & inundado e não inundado \\
\hline EC & 2 & 8 & 0,60 & não inundado \\
\hline ED & 2 & 8 & 0,60 & não inundado \\
\hline EE & 2 & 8 & 0,60 & não inundado e inundado \\
\hline
\end{tabular}




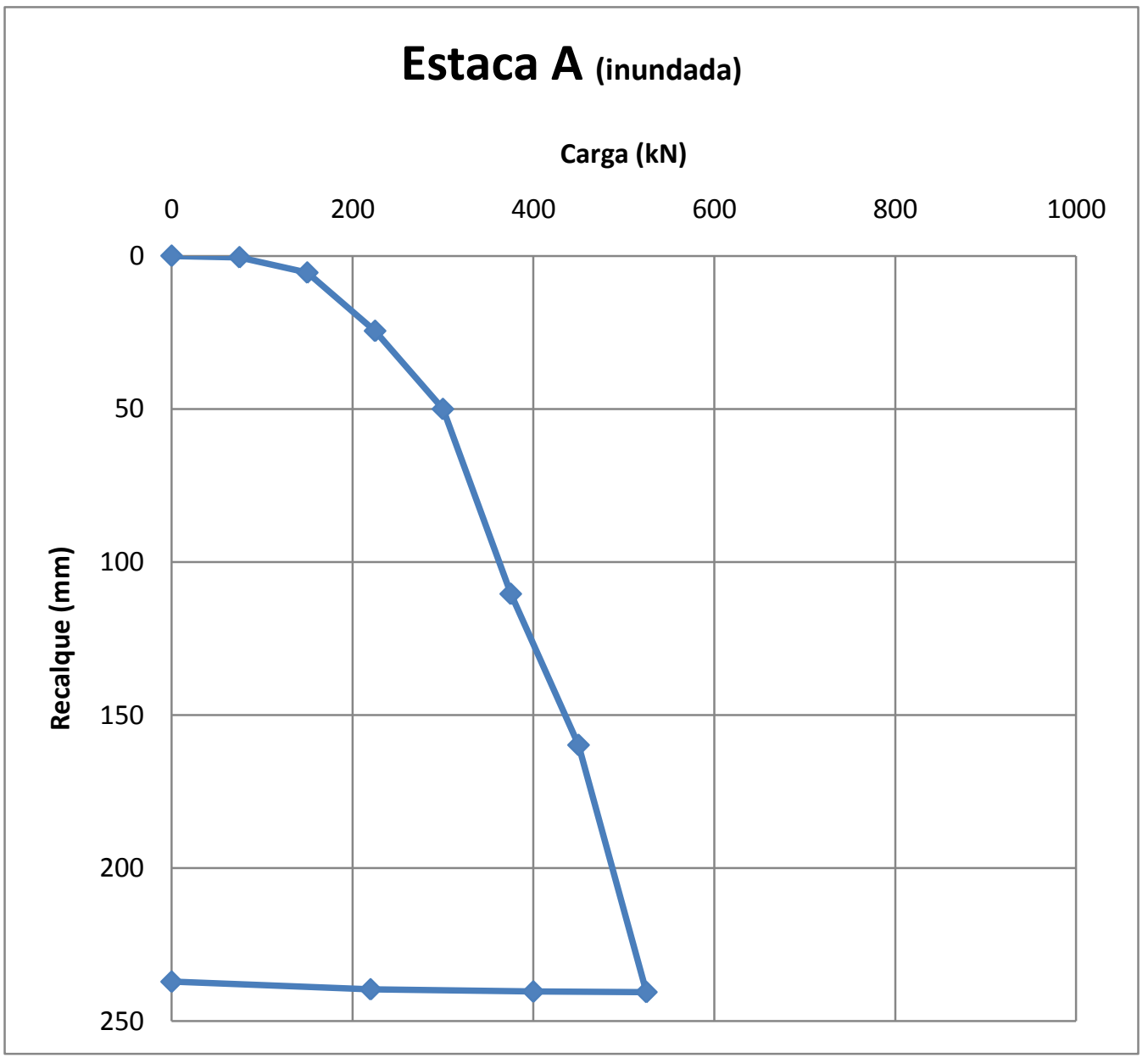

Figura 5.5 - Curva carga x recalque (estaca A, terreno inundado) 


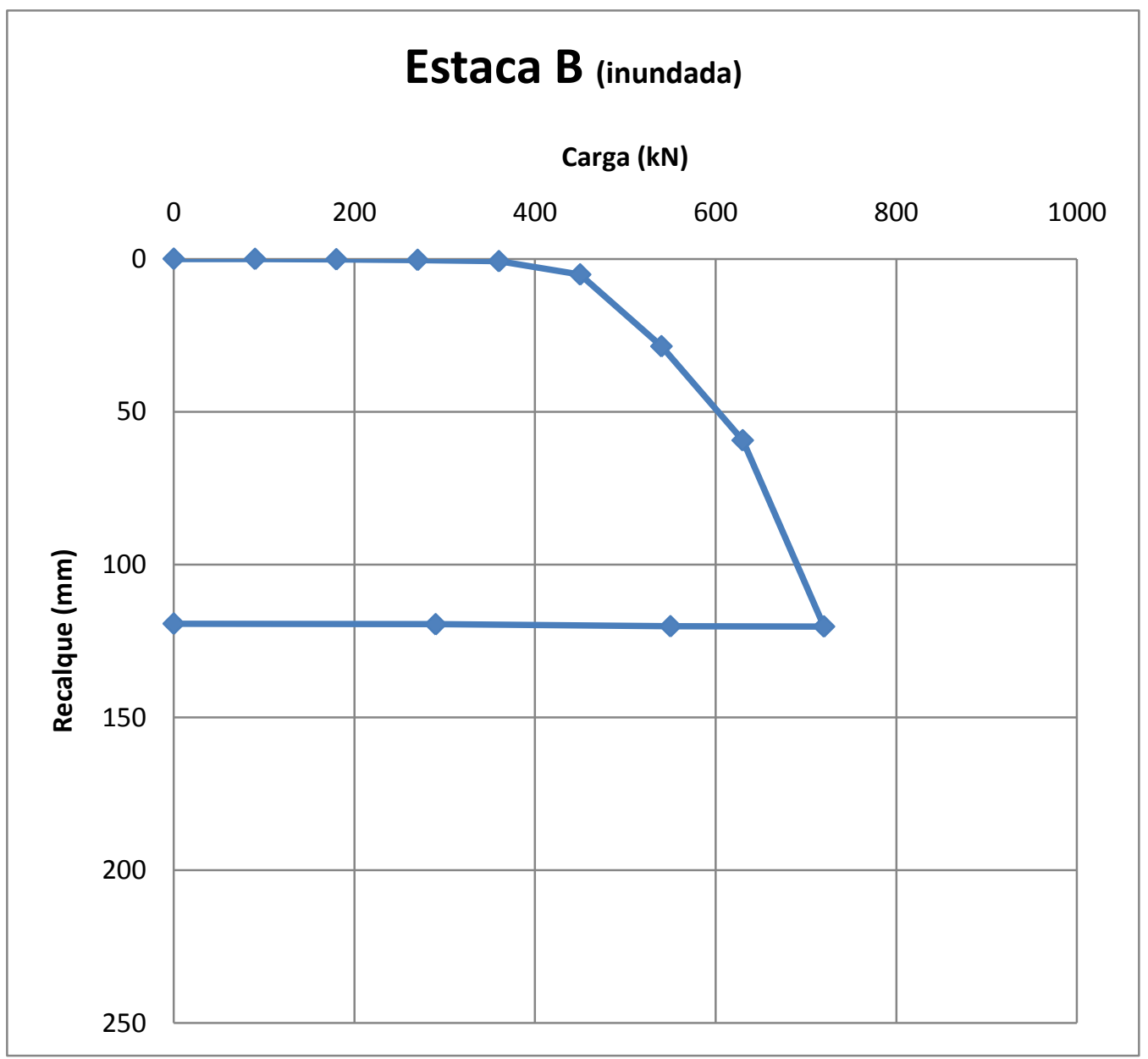

Figura 5.6 - Curva carga $\times$ recalque (estaca B, terreno inundado) 


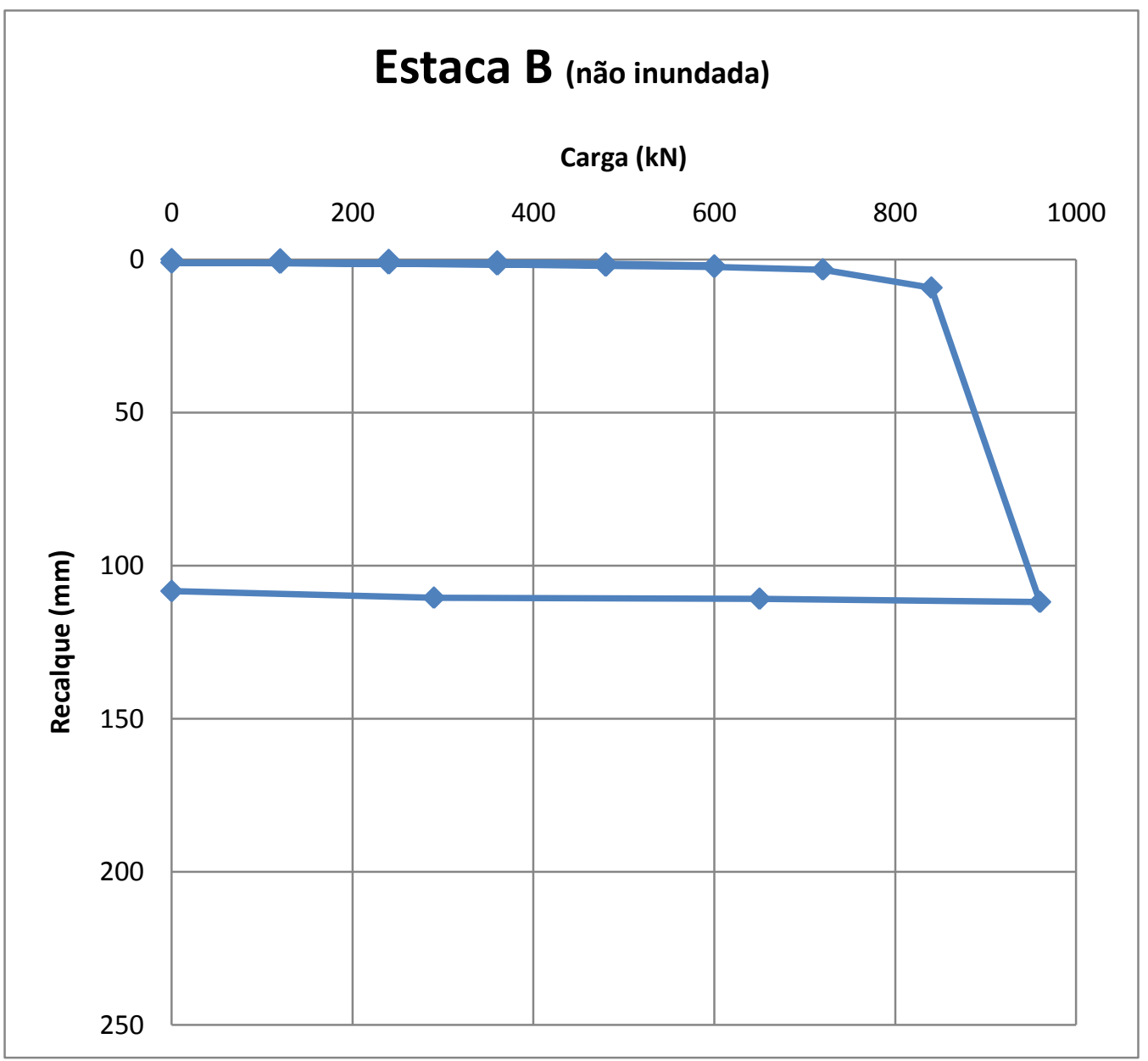

Figura 5.7 - Curva carga x recalque (estaca B, terreno não inundado) 


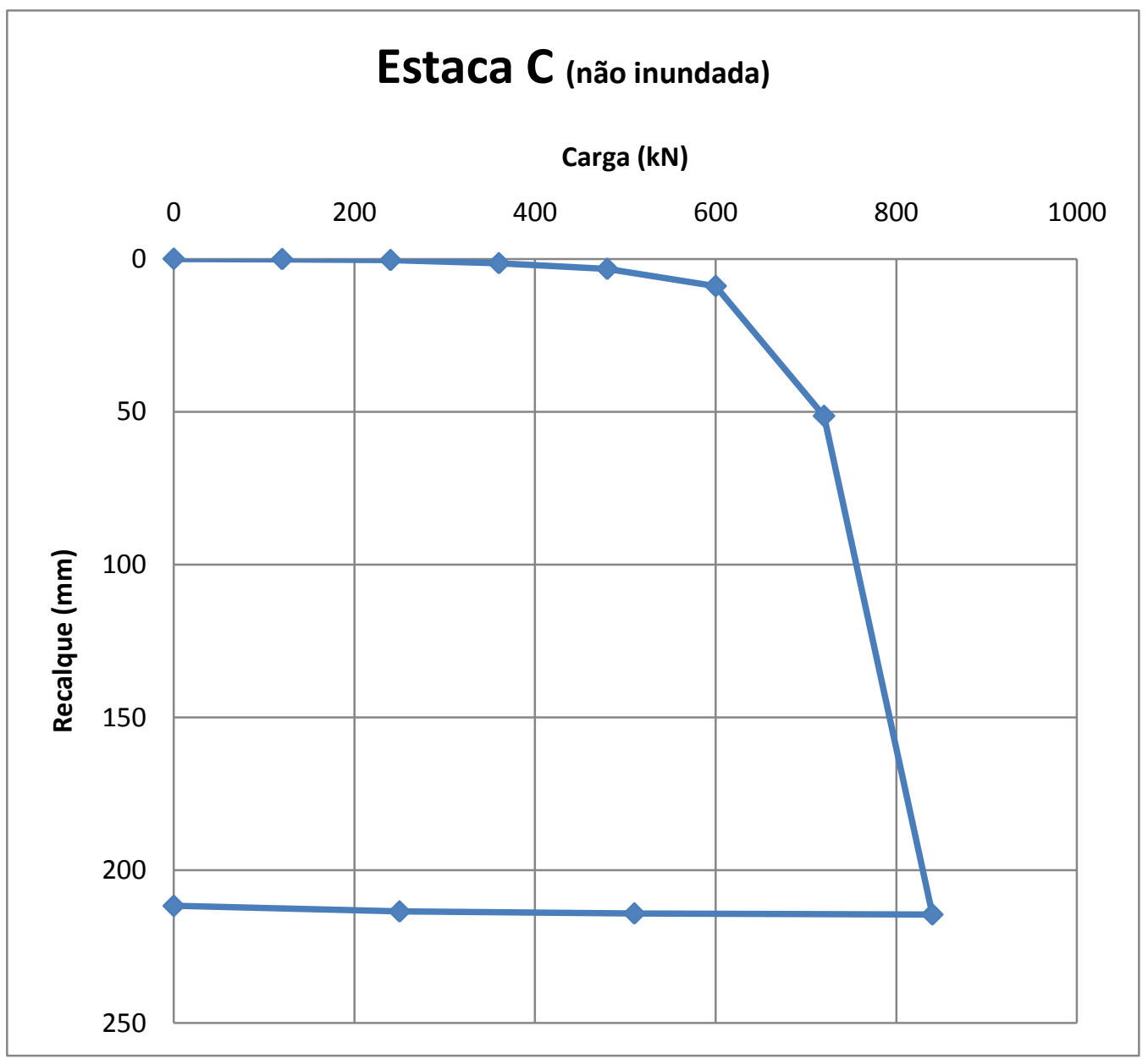

Figura 5.8 - Curva carga x recalque (estaca C, terreno não inundado) 


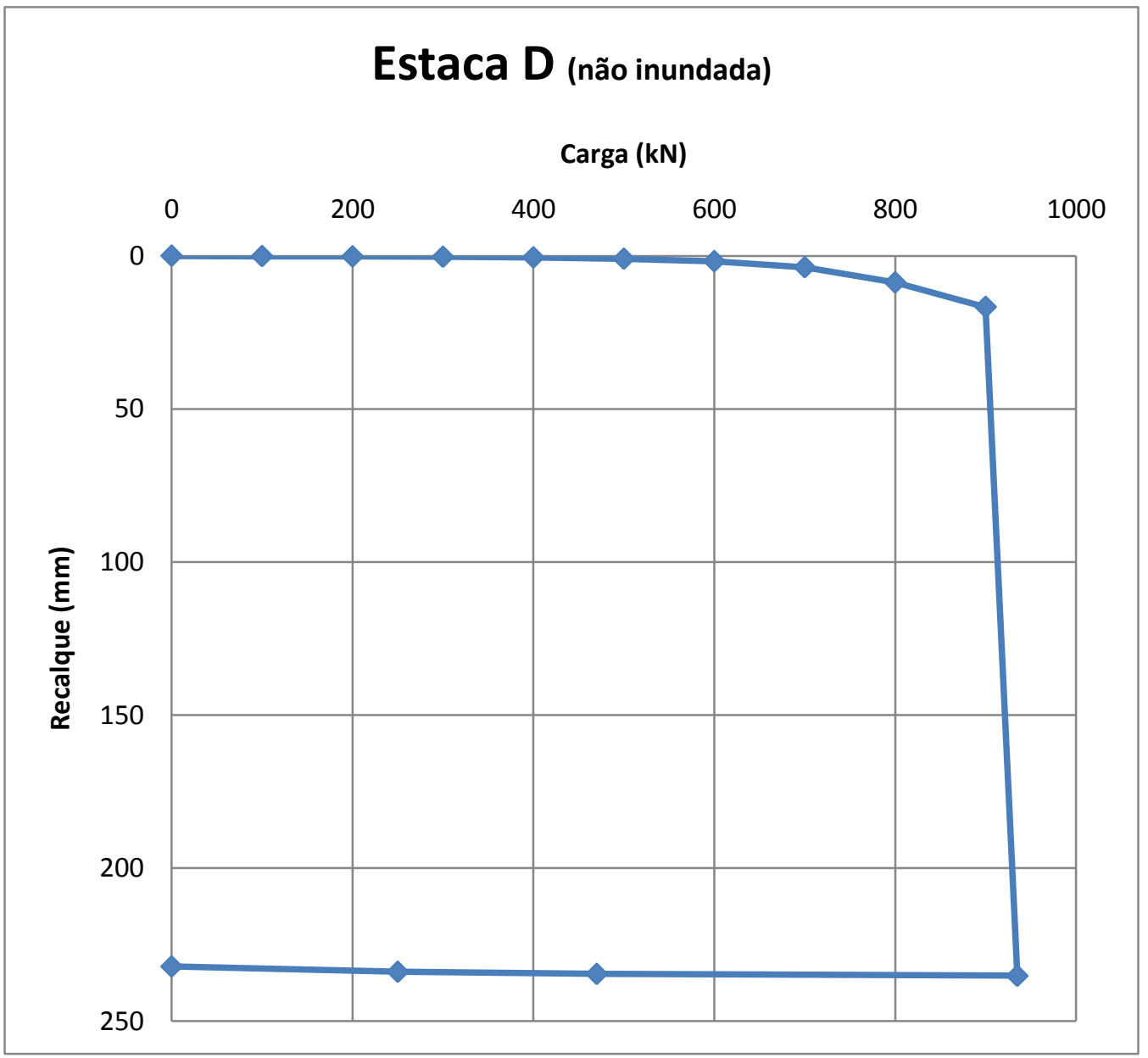

Figura 5.9 - Curva carga x recalque (estaca D, terreno não inundado) 


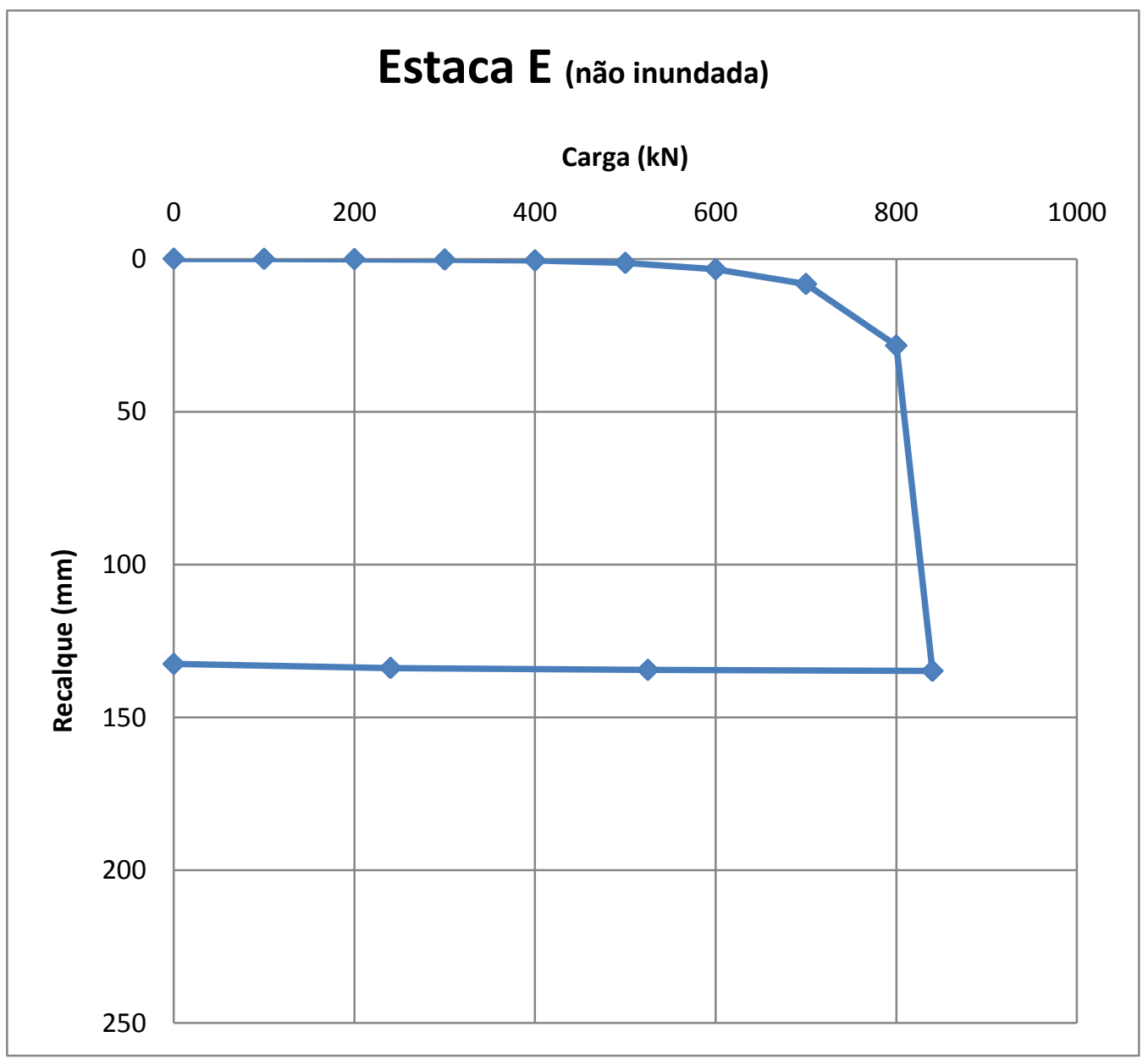

Figura 5.10 - Curva carga x recalque (estaca E, terreno não inundado) 


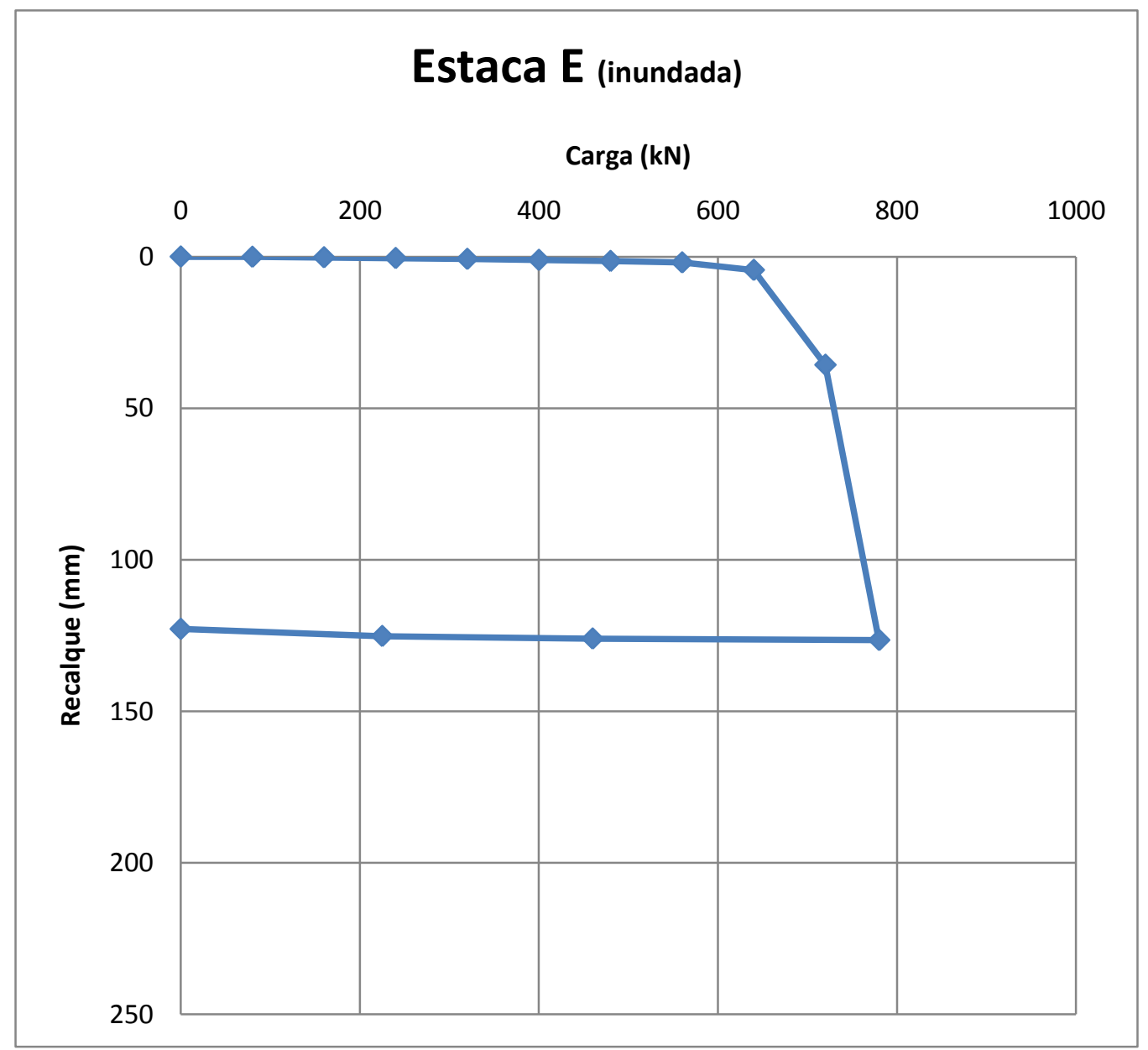

Figura 5.11 - Curva carga x recalque (estaca E, terreno inundado)

\subsection{SUCÇÃO MATRICIAL E PLUVIOMETRIA}

A seguir são apresentados valores de sucção matricial medidos no campo experimental, juntamente com os níveis d'água para os meses de novembro de 2009 até maio de 2010, quando foram realizadas as provas de carga nas estacas de base injetada. 


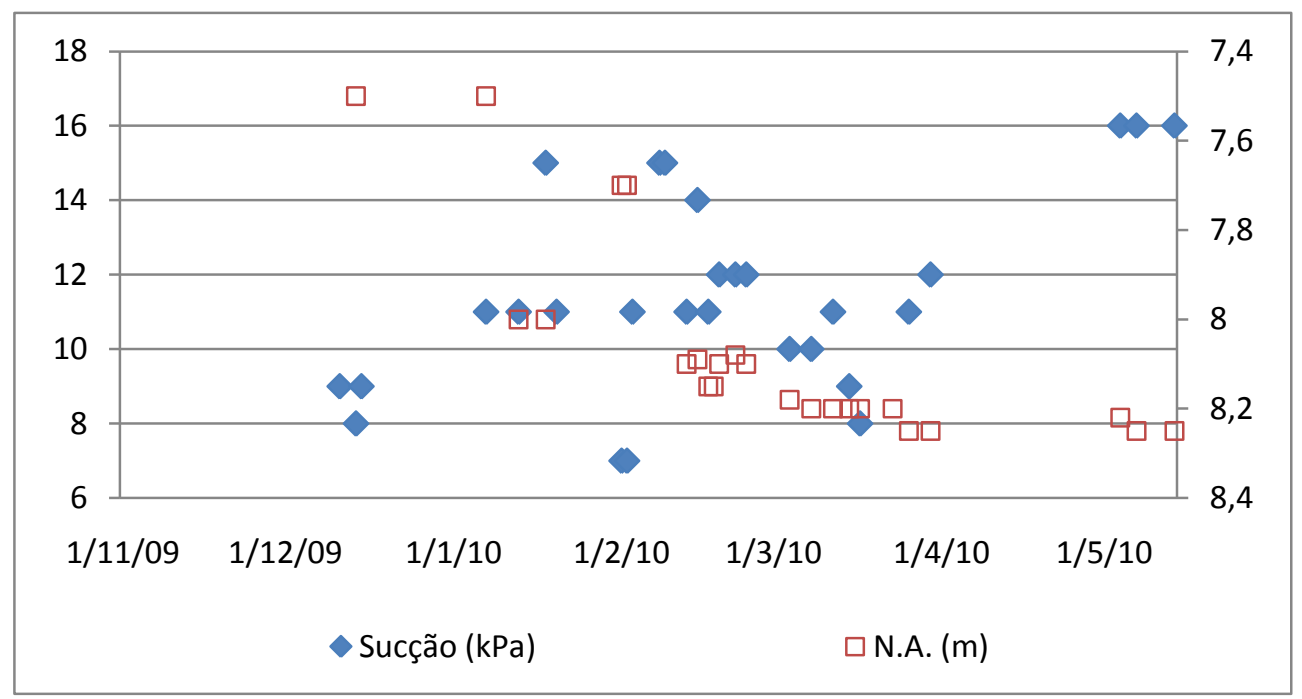

Figura 5.12 - Valores de sucção matricial e níveis d'água medidos no campo

São apresentadas também as precipitações médias diárias fornecidas pela Embrapa Pecuária Sudeste (Fazenda Canchim, São Carlos-SP) para o mesmo período.

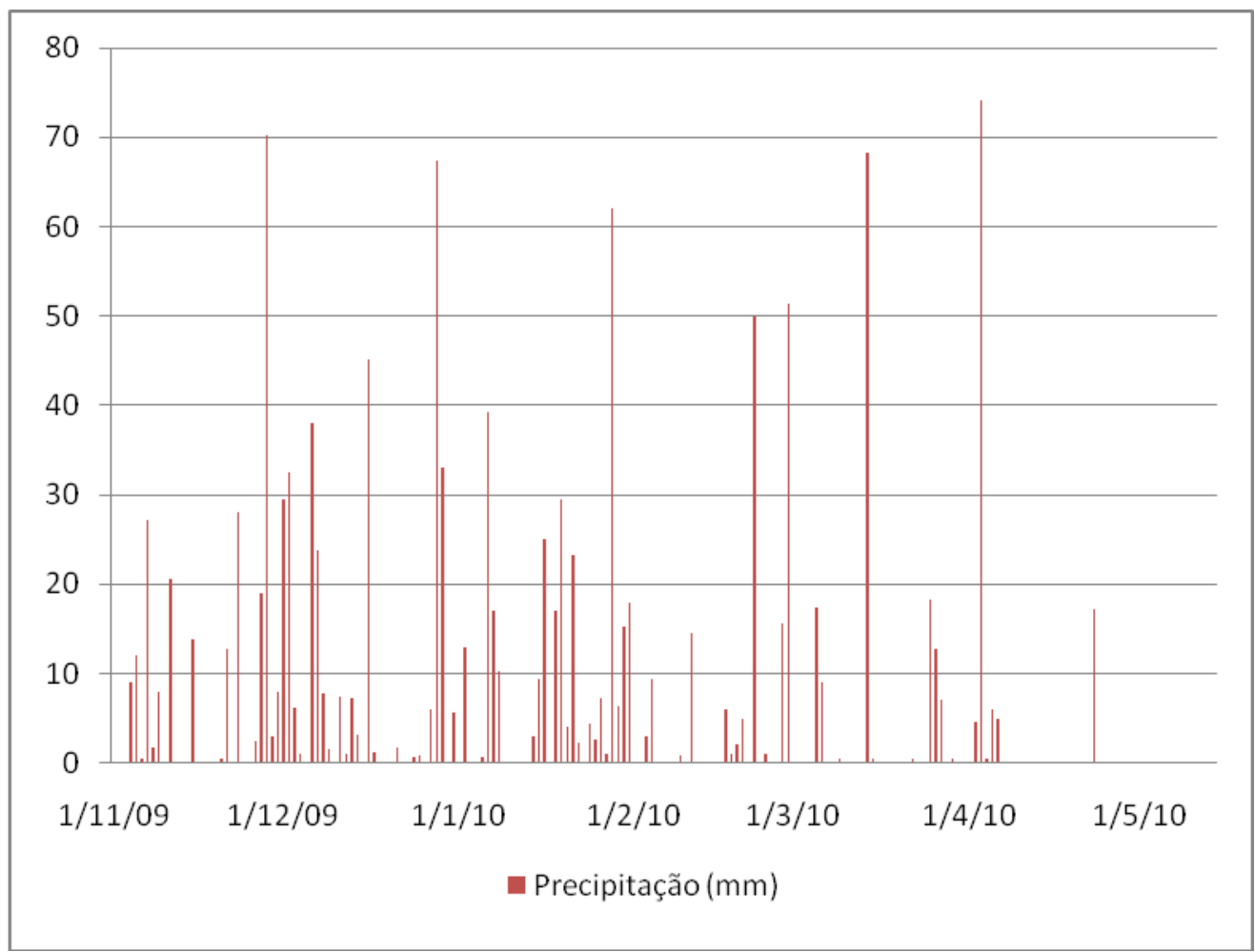

Figura 5.13 - Valores de precipitação média diária (Embrapa, 2010) 


\title{
6. ANÁLISE DOS RESULTADOS
}

\subsection{PROVAS DE CARGA NAS BASES INJETADAS}

\author{
ENSAIOS NÃO INUNDADOS
}

Nas Figuras 6.1 e 6.2 são mostradas as curvas tensão $x$ recalque obtidas nas sucessivas provas de carga realizadas nas duas cavas não inundadas (4 e 9): 1) provas de carga estática (Costa, 1999), 2) provas de carga dinâmica (Moraes, 2005), 3) provas de carga estática (Moraes, 2005) e 4) provas de carga estática realizadas nesta pesquisa. Os ensaios dos itens 1, 2 e 3 foram realizados sobre placa metálica circular com diâmetro igual a $0,80 \mathrm{~m}$, e os do item 4 foram realizados sobre bases injetadas executadas sob cilindros de concreto armado com diâmetro da base igual a 0,80 m. Os quatro gráficos exibem o recalque acumulado conforme a sequência de execução. Para as provas de carga dinâmica, são exibidas as forças resistentes estáticas encontradas através de análises CAPWAP® e divididas pela área da placa, obtendo-se assim as tensões resistentes.

As três primeiras curvas tensão $\mathrm{x}$ recalque de cada uma das Figuras 6.1 e 6.2 apresentam uma relação praticamente linear entre o recalque e a correspondente carga aplicada, na fase de deformações plásticas, e descarregamento praticamente horizontal. Este tipo de curva pode ser observado em outras provas de carga realizadas no mesmo local, em placa e em tubulão.

Assim como no trabalho de Benvenutti (2001), observa-se que a parte final de cada curva carga $\mathrm{x}$ recalque dos três primeiros ensaios de uma mesma cava constitui uma espécie de trecho reto único. Assim, desconsiderando o descarregamento e o carregamento subsequente, até atingir a tensão máxima do ensaio anterior, pode-se obter uma curva única, com razoável coerência. Essa curva, formada pela união das três curvas das três provas de carga (estática, dinâmica, estática) realizados em cada cava, é do tipo aberta, típica de todos os ensaios de placa realizados no local. A continuidade entre os 
trechos finais das curvas deixa de existir no último ensaio, realizado após a melhoria do sistema base injetada-solo através de injeção de calda de cimento sob os cilindros de concreto. Nota-se que há um aumento considerável de capacidade de carga do sistema melhorado pelas injeções.

Este aumento fica ainda mais evidente quando se comparam as provas de carga realizadas após a injeção (PCE4i e PCE9i) com as projeções feitas a partir dos dados da prova de carga Q1 (curvas em azul das Figuras 6.1 e 6.2). Para estas projeções os recalques foram extrapolados, como se a primeira prova de carga estática realizada em cada cava tivesse sido levada a tensões maiores. Para encontrar a equação das curvas, utilizando os pontos dos ensaios, foi utilizado o programa freeware Tablecurve ${ }^{\circledR}$, que testa um catálogo de equações para um conjunto de pontos e apresenta os melhores ajustes em função do $R^{2}$. As curvas com melhor ajuste, apresentadas nas Figuras 6.1 e 6.2 tiveram $R^{2}$ igual a 0,9999 e 0,9994 para as cavas 9 e 4 respectivamente. 


\section{Cava 9}

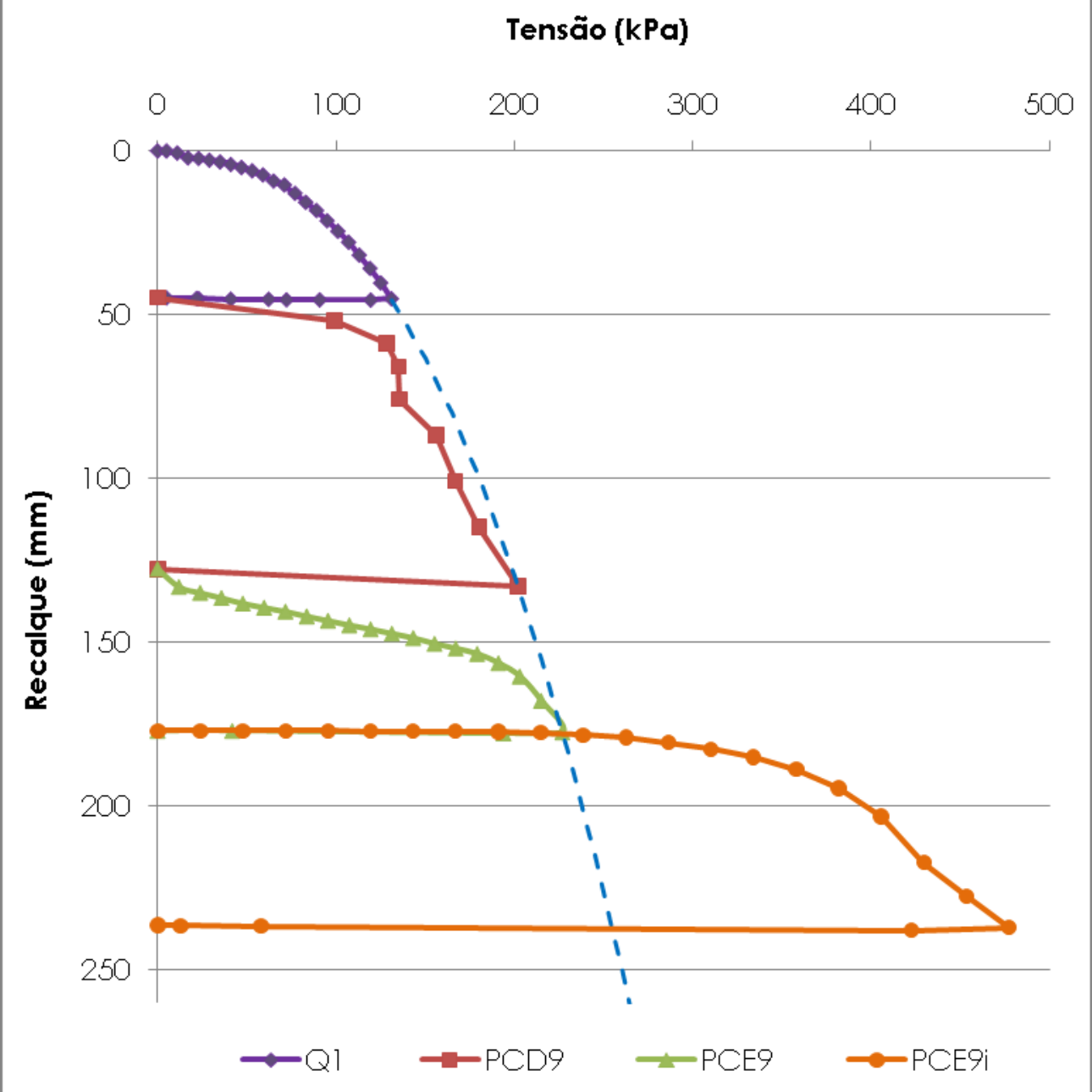

Figura 6.1 - Provas de carga realizadas na cava 9 e projeção da prova de carga Q1 (em azul). Terreno não inundado 
117

Cava 4

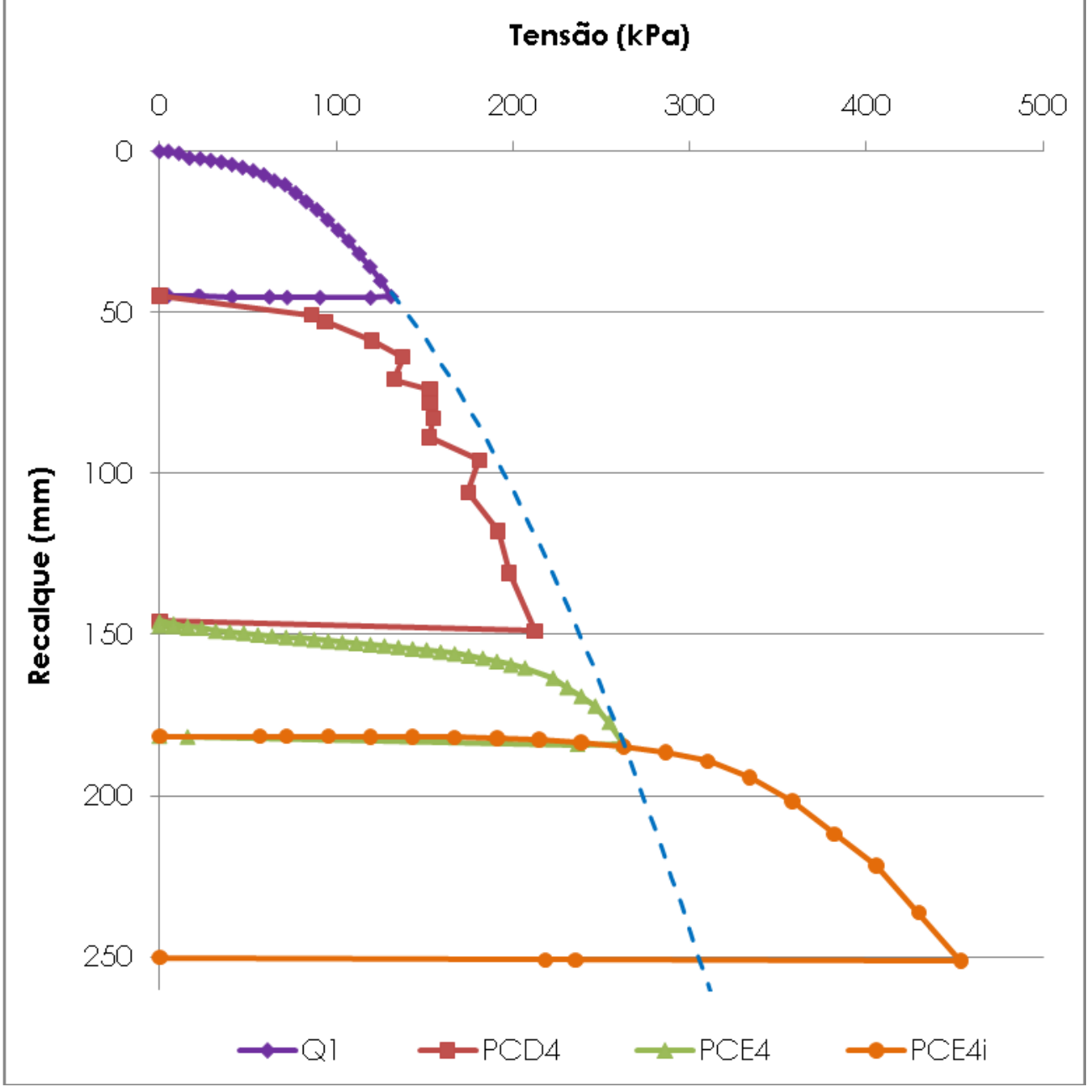

Figura 6.2 - Provas de carga realizadas na cava 4 e projeção da prova de carga Q1 (em azul). Terreno não inundado 
ENSAIOS INUNDADOS

Os ensaios inundados (cavas 7 e 8) são mostrados nas figuras 6.3 e 6.4, na mesma sequência: 1) provas de carga estática (Costa, 1999), 2) provas de carga dinâmica (Moraes, 2005), 3) provas de carga estática (Moraes, 2005) e 4) provas de carga estática realizadas nesta pesquisa.

A linearidade do segundo trecho das curvas dos três primeiros ensaios é interrompida na prova de carga dinâmica, pois como o ensaio é muito rápido, não há tempo para dissipação das pressões neutras. Além disso, na prova de carga estática realizada após a dinâmica, tanto para a cava 7 quanto para a 8, observa-se uma mudança de inclinação da curva nos últimos pontos, que ficaria mais clara se tivessem sido realizados mais alguns estágios de carga.

Foi utilizado então o programa freeware Tablecurve® para fazer projeções dos recalques se as provas de carga estática anteriores tivessem sido levadas a tensões maiores. Nas Figuras 6.3 e 6.4 são mostradas, em azul, as projeções para o ensaio QS1, passando pelos últimos pontos das provas de carga PCE7 e PCE8. O R² obtido para as duas curvas foi igual a 0,9996 e 0,9995 para as cavas 7 e 8 respectivamente.

Comparando-se as curvas obtidas nos ensaios realizados após as injeções com as projeções das provas de carga anteriores, observa-se aumento da capacidade de carga devido à melhoria do sistema base injetada-solo. 


\section{Cava 7}

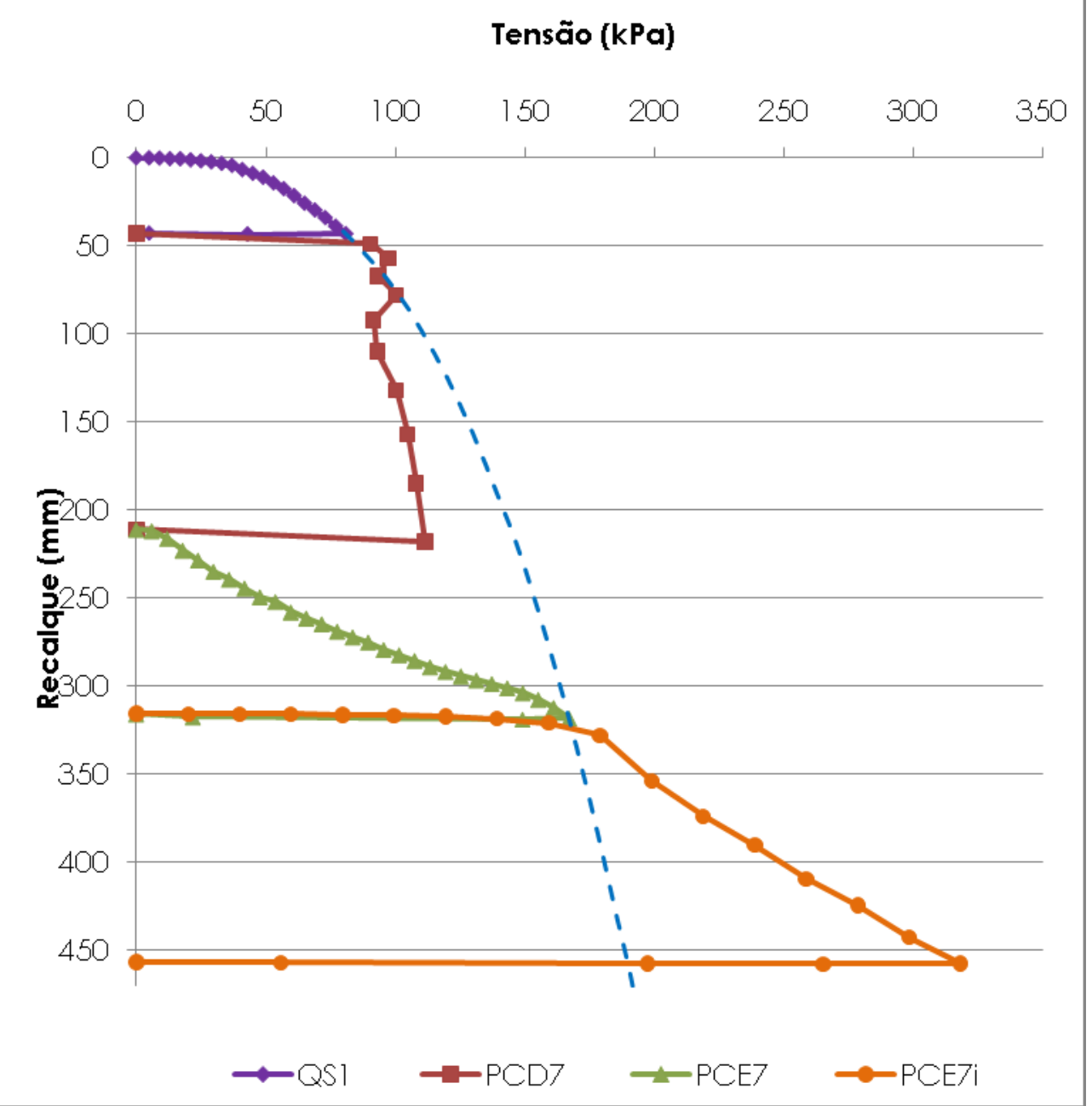

Figura 6.3 - Provas de carga realizadas na cava 7 e projeção da prova de carga QS1 (em azul). Terreno inundado 


\section{Cava 8}

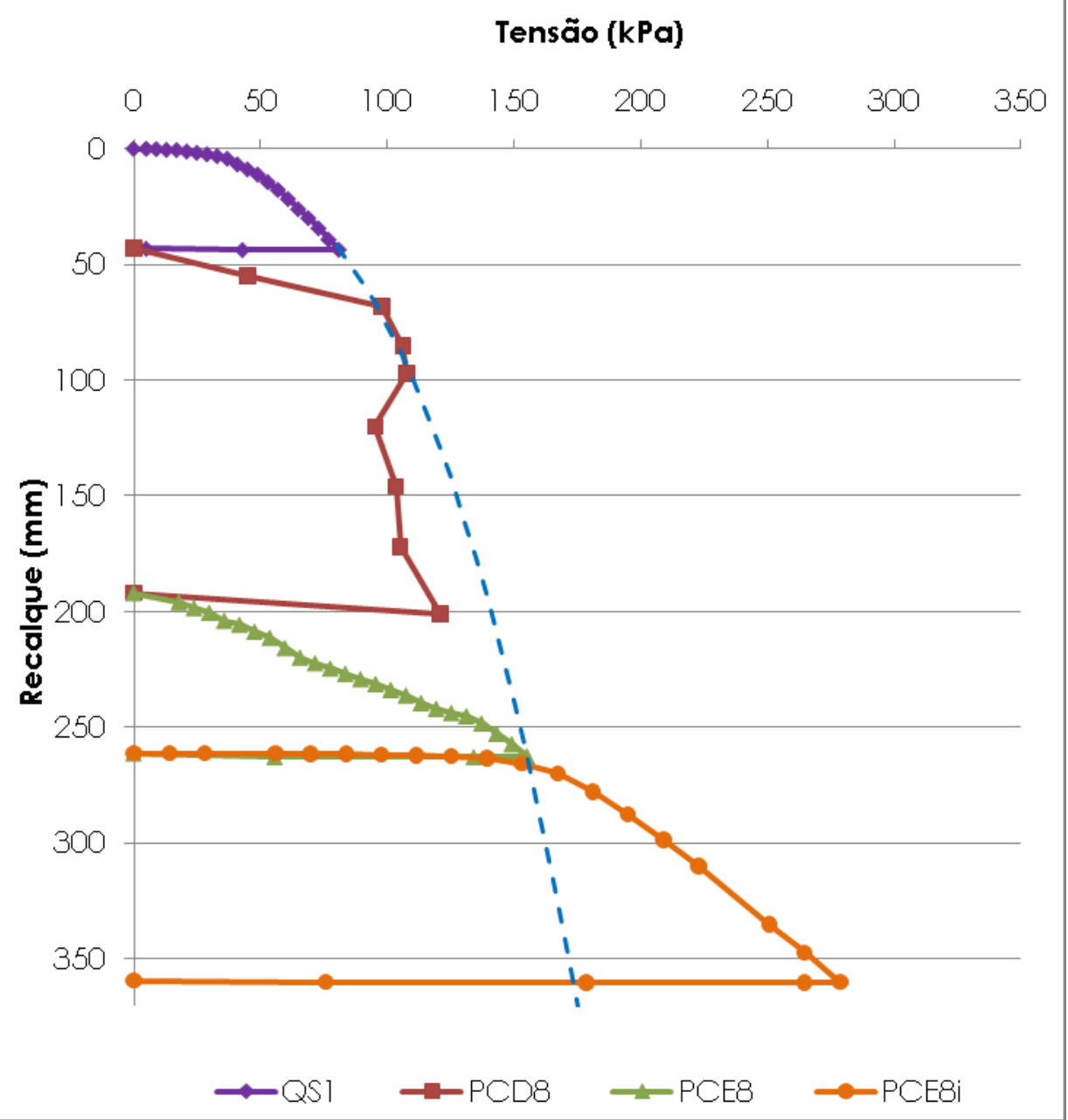

Figura 6.4 - Provas de carga realizadas na cava 8 e projeção da prova de carga QS1 (em azul). Terreno inundado 


\section{CAPACIDADE DE CARGA}

As curvas tensão $x$ recalque das Figuras 6.1 a 6.4 apresentam crescimento da capacidade de carga com os recalques. Para as três provas de carga estática apresentadas em cada figura o descarregamento é praticamente horizontal. Esse tipo de curva apresentando aumento contínuo da carga com a penetração e descarregamento horizontal, pode ser observado em outras provas de carga realizadas no mesmo local, em placa e em tubulão. Benvenutti (2001) comprovou esse aumento com a realização de sucessivas provas de carga estática no mesmo tubulão. O autor observa que a parte final das curvas carga $\mathrm{x}$ recalque dos sucessivos ensaios de um mesmo tubulão constituem um único trecho reto, se mantido o mesmo tipo de ensaio, o que é típico de todos os ensaios de placa e tubulão realizados nesse local, inclusive os desta pesquisa.

Como este tipo de curva "aberta" não caracteriza ruptura nítida do sistema, pois qualquer acréscimo de tensão causa aumento da rigidez do solo, nem permite que se aplique o modelo de ruptura física (Van der Veen, por exemplo) é necessário adotar um critério de ruptura convencional na interpretação dos sucessivos ensaios.

Como anteriormente à realização das provas de carga o solo ao redor dos cilindros de concreto foi removido e pode se comparar diretamente com ensaios em placa, foi adotado o critério de ruptura pelo qual a capacidade de carga corresponde a um recalque igual a $25 \mathrm{~mm}$ (Teixeira e Godoy, 1998).

Nas Tabelas 6.1 a 6.4 são apresentados os valores de capacidade de carga para cada ensaio de cada cava, a sucção matricial no momento do ensaio e as profundidades iniciais. A profundidade inicial de um ensaio é o recalque acumulado do ensaio anterior. 
Tabela 6.1 - Valores de capacidade de carga e sucção (cava 9, terreno não inundado)

\begin{tabular}{|c|c|c|c|}
\hline Ensaio & $\begin{array}{c}\sigma_{r} \\
(\mathrm{kPa})\end{array}$ & $\begin{array}{c}\text { Sucção } \\
(\mathrm{kPa})\end{array}$ & $\begin{array}{c}\text { prof. } \\
\text { inicial do } \\
\text { ensaio } \\
(\mathrm{mm})\end{array}$ \\
\hline Q1 & 102 & 15 & 0 \\
\hline PCD9 & 135 & 16 & 45 \\
\hline PCE9 & 173 & 25 & 128 \\
\hline PCE9i & 403 & 20 & 177 \\
\hline
\end{tabular}

Tabela 6.2 - Valores de capacidade de carga e sucção (cava 4, terreno não inundado)

\begin{tabular}{|c|c|c|c|}
\hline Ensaio & $\begin{array}{c}\sigma_{r} \\
(\mathrm{kPa})\end{array}$ & $\begin{array}{c}\text { Sucção } \\
(\mathrm{kPa})\end{array}$ & $\begin{array}{c}\text { prof. } \\
\text { inicial do } \\
\text { ensaio } \\
(\mathrm{mm})\end{array}$ \\
\hline Q1 & 102 & 15 & 0 \\
\hline PCD4 & 133 & 16 & 45 \\
\hline PCE4 & 243 & 22 & 146 \\
\hline PCE4i & 370 & 20 & 182 \\
\hline
\end{tabular}

Tabela 6.3 - Valores de capacidade de carga e sucção (cava 7, terreno inundado)

\begin{tabular}{|c|c|c|c|}
\hline Ensaio & $\begin{array}{c}\text { or } \\
(\mathrm{kPa})\end{array}$ & $\begin{array}{c}\text { Sucção } \\
(\mathrm{kPa})\end{array}$ & $\begin{array}{c}\text { prof. } \\
\text { inicial do } \\
\text { ensaio } \\
(\mathrm{mm})\end{array}$ \\
\hline QS1 & 64 & $\approx 0$ & 0 \\
\hline PCD7 & 94 & $\approx 0$ & 43 \\
\hline PCE7 & 31 & $\approx 0$ & 211 \\
\hline PCE7i & 189 & $\approx 0$ & 316 \\
\hline
\end{tabular}

Tabela 6.4 - Valores de capacidade de carga e sucção (cava 8, terreno inundado)

\begin{tabular}{|c|c|c|c|}
\hline Ensaio & $\begin{array}{c}\sigma r \\
(\mathrm{kPa})\end{array}$ & $\begin{array}{c}\text { Sucção } \\
(\mathrm{kPa})\end{array}$ & $\begin{array}{c}\text { prof. } \\
\text { inicial do } \\
\text { ensaio } \\
(\mathrm{mm})\end{array}$ \\
\hline QS1 & 64 & $\approx 0$ & 0 \\
\hline PCD8 & 98 & $\approx 0$ & 43 \\
\hline PCE8 & 32 & $\approx 0$ & 192 \\
\hline PCE8i & 193 & $\approx 0$ & 261 \\
\hline
\end{tabular}

É possível observar a partir dos ensaios não inundados que há uma tendência de crescimento da capacidade de carga com o aumento da profundidade para os três 
primeiros ensaios e que este crescimento é bem maior no quarto ensaio (após a injeção). Isto pode ser mais bem observado a partir dos gráficos das Figuras 6.5 e 6.6, que exibem as capacidades de carga em função dos recalques (profundidade inicial do ensaio mais 25 $\mathrm{mm}$ relativos ao critério de ruptura). Os gráficos também apresentam a capacidade de carga calculada utilizando-se as curvas de projeção dos ensaios iniciais das Figuras 6.1 e 6.2. O resultado "esperado" para o sistema sem injeção é apresentado com uma linha tracejada nas Figuras 6.5 e 6.6. As linhas cheias representam os valores encontrados nas provas de carga.

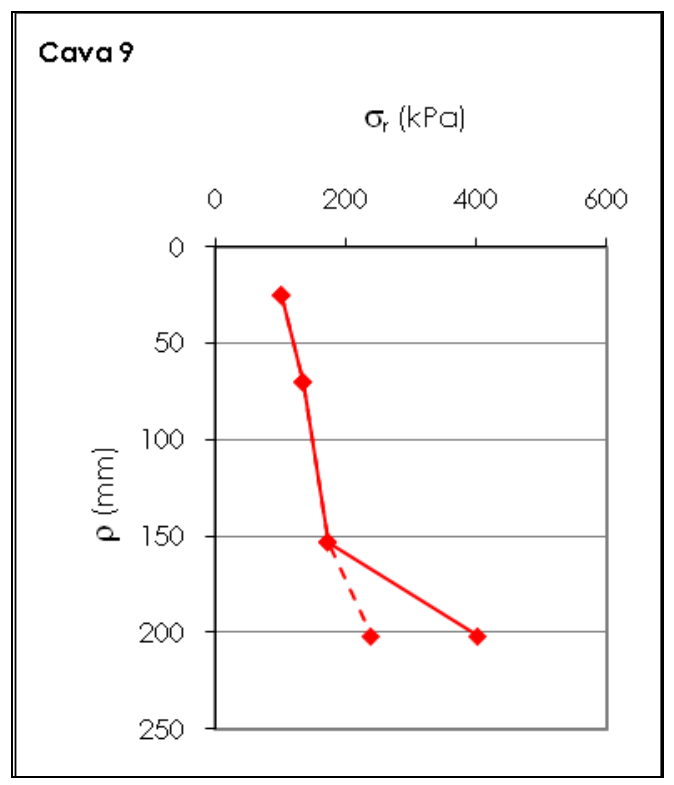

Figura 6.5 - Capacidade de carga de cada ensaio x recalque (cava não inundada) 


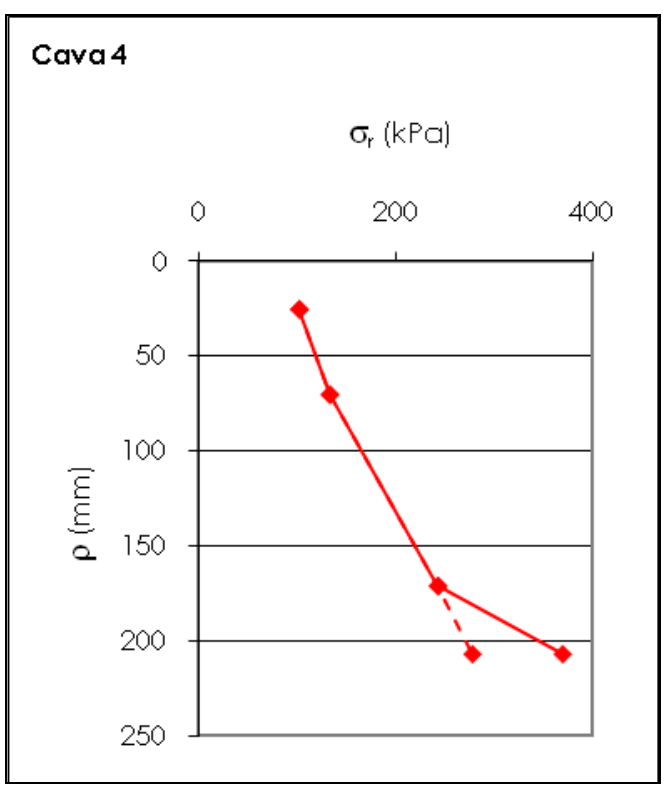

Figura 6.6 - Capacidade de carga de cada ensaio x recalque (cava não inundada)

O aumento da capacidade de carga após a injeção em relação à projeção dos dados do primeiro ensaio realizado foi de $67 \%$ para a cava 9. Já na cava 4, houve um aumento de 33\% em relação à projeção da primeira prova de carga estática.

A interpretação dos ensaios inundados é um pouco prejudicada, pois as provas de carga dinâmica não mostram o comportamento usual deste tipo de solo, que é uma curva aberta. Além disso, provas de carga estática realizadas sucessivamente em um mesmo elemento de fundação neste campo experimental, mostram descarregamento praticamente horizontal e recarregamento idem, a não ser pelo terceiro ensaio realizado em cada uma das cavas inundadas após a prova de carga dinâmica, cujo recarregamento apresenta um desenvolvimento atípico dos recalques.

Os valores de capacidade de carga em função do recalque para as cavas 7 e 8 estão plotados nos gráficos das Figuras 6.7 e 6.8 respectivamente. 


\section{Cava 7}

$\sigma_{\mathrm{r}}(\mathrm{kPa})$

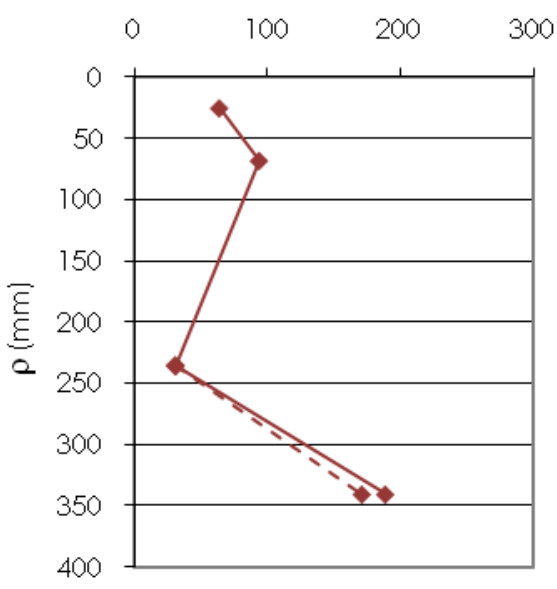

Figura 6.7 - Capacidade de carga de cada ensaio x recalque (cava inundada)

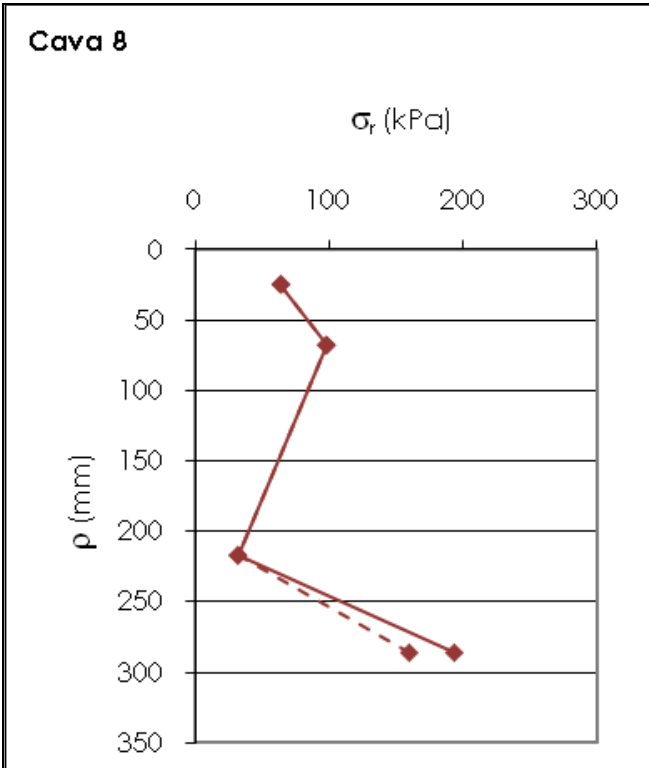

Figura 6.8 - Capacidade de carga de cada ensaio x recalque (cava inundada)

O aumento da capacidade de carga após as injeções em relação à projeção do primeiro ensaio realizado foi de $11 \%$ para a cava 7 e $21 \%$ para a cava 8. 


\subsection{EXTRAÇÃO DOS CILINDROS DE CONCRETO}

Após a extração dos cilindros foi possível observar que não houve mistura ou permeação da calda no solo. Apesar das baixas pressões utilizadas, objetivando a permeação da calda, o processo de injeção se deu predominantemente por compactação.

A ideia inicial era extrair blocos indeformados da mistura de solo e calda para realização de ensaios de compressão simples e cisalhamento direto, o que não foi possível, pois durante a extração, houve movimentação e expansão do solo sob o cilindro, que ficou fofo com pedaços de calda endurecida (ver Figuras 6.9 e 6.10). Isso também impossibilitou a realização de ensaios com penetrômetro manual portátil para tentar detectar o aumento da compactação do solo.

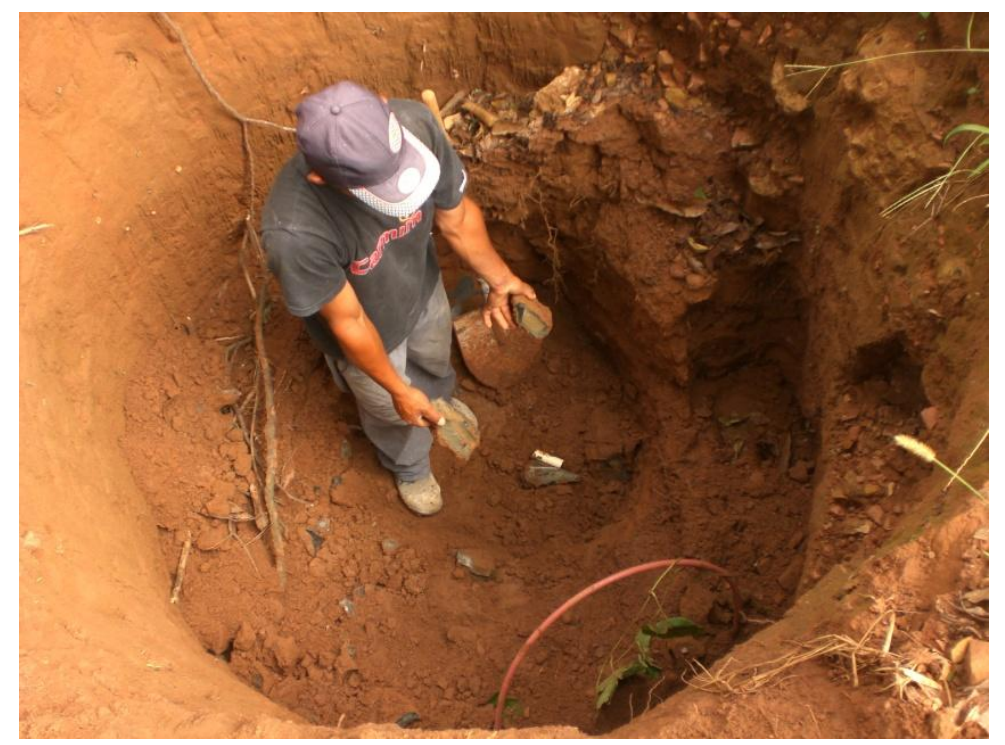

Figura 6.9 - Pedaços de calda no fundo da cava após extração do cilindro 


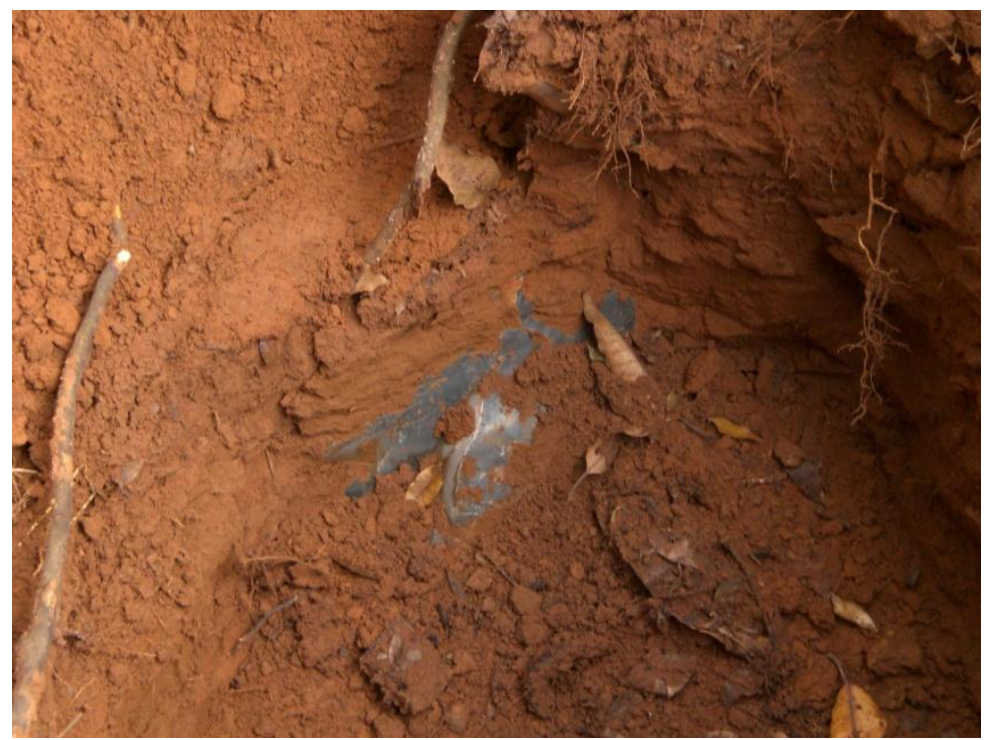

Figura 6.10 - Calda e solo fofo após extração do cilindro

As Figuras 6.11 a 6.13 mostram os cilindros após a extração realizada por um guindaste.

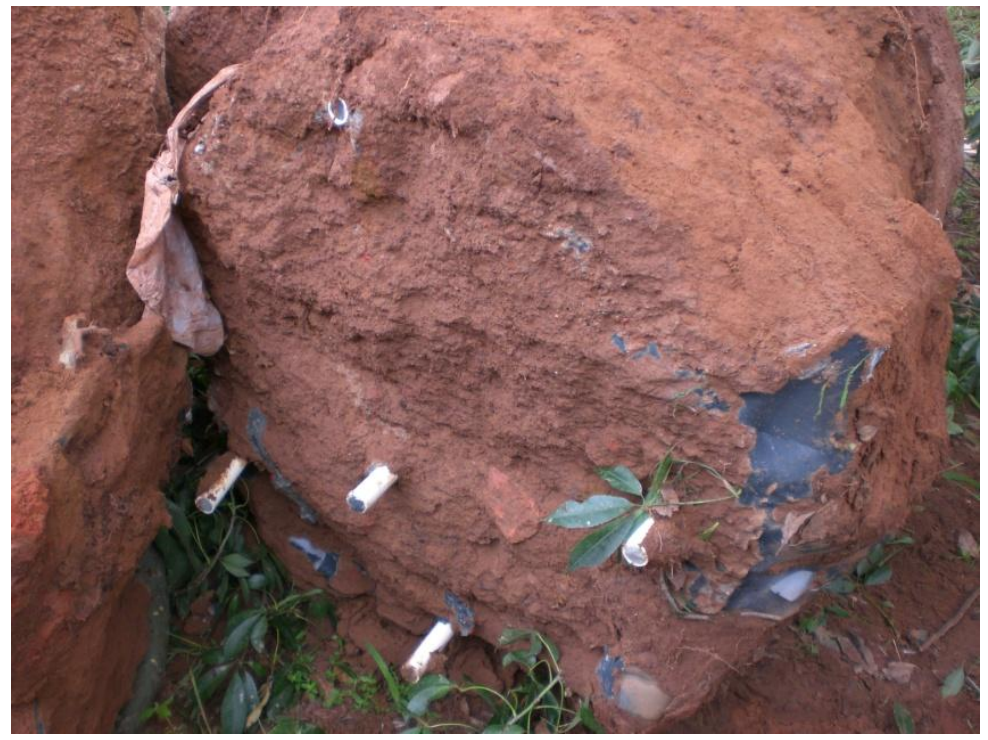

Figura 6.11 - Base do cilindro com injeção 


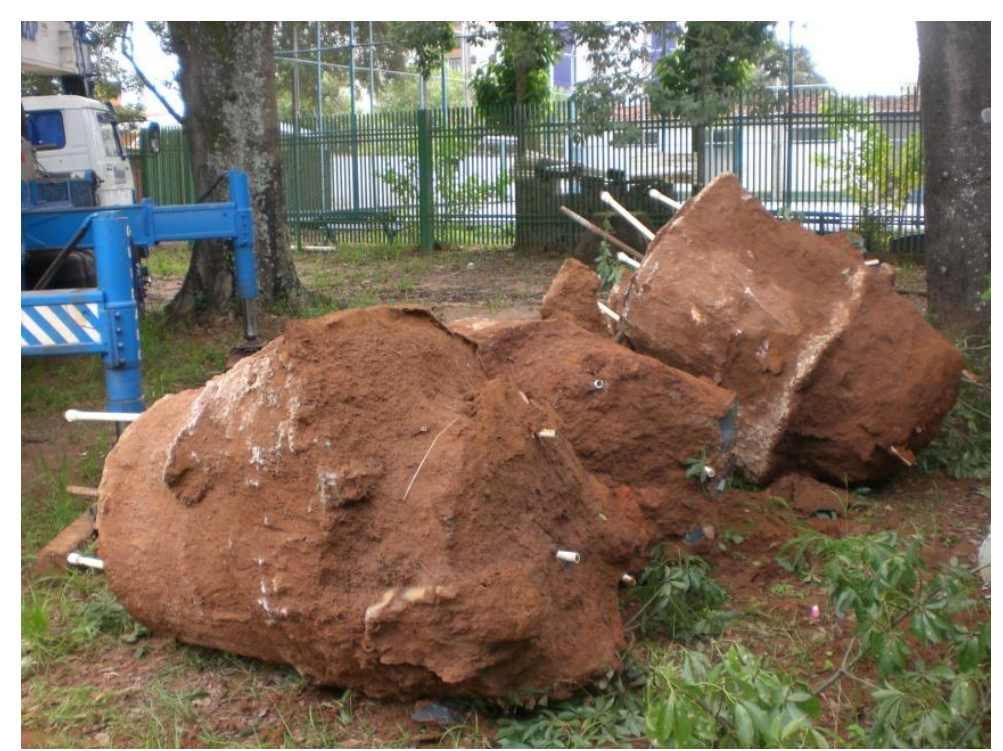

Figura 6.12 - Cilindros extraídos

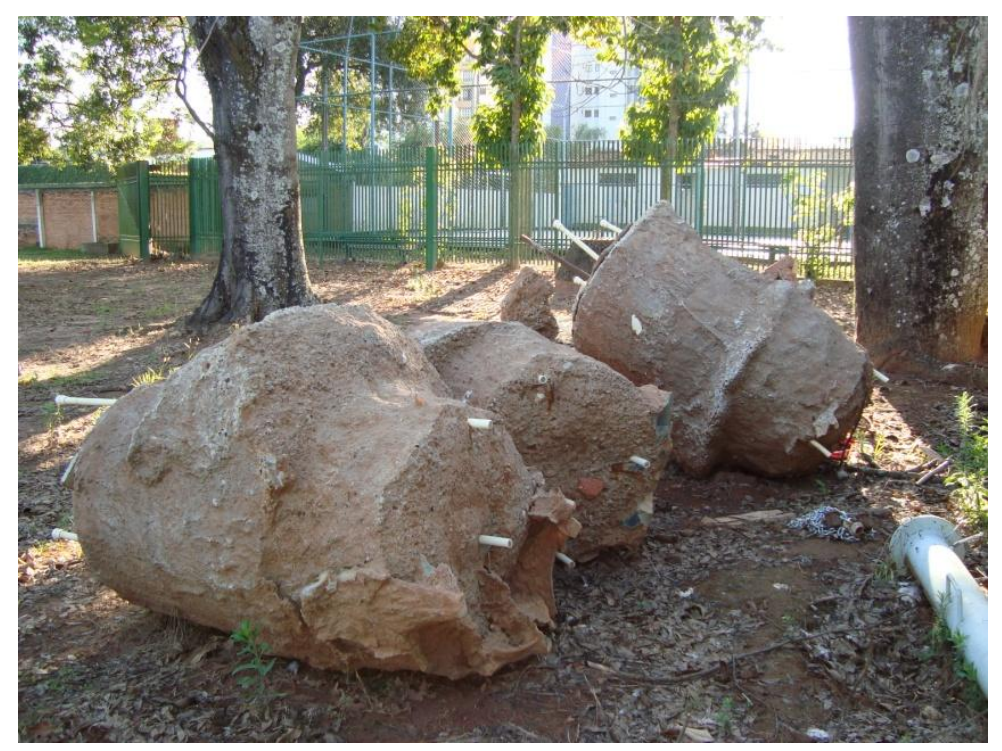

Figura 6.13 - Cilindros extraídos após lavagem com lavadora de alta pressão

Após a extração, os cilindros foram lavados com auxílio de uma lavadora de alta pressão para retirada do solo aderido e melhor observação da distribuição da calda.

Nas Figuras 6.13 a 6.15 veem-se as pontas dos tubos de PVC por onde foram executadas as injeções. Durante a extração, boa parte da calda permaneceu no solo, e não foi "sacada" junto com o cilindro. 
Foi possível perceber que a calda se espalhou para as laterais, aumentando o diâmetro da base do cilindro (Figuras 6.14 e 6.15). Isso, em conjunto com a melhoria do solo, promoveu o aumento na capacidade de carga demonstrado através das provas de carga realizadas.

Em alguns furos, porem, a calda se direcionou somente para baixo (Figura 6.16), o que melhora o solo, mas não aumenta o diâmetro da base. Com isso, perde-se uma das parcelas promotoras do aumento da capacidade de carga.

$\mathrm{Na}$ construção das estacas tentou-se controlar o direcionamento da calda. Foi colocado um disco de madeira no fundo do furo, antes da concretagem. Com isso, a base foi impermeabilizada, forçando a calda a se espalhar para as laterais.

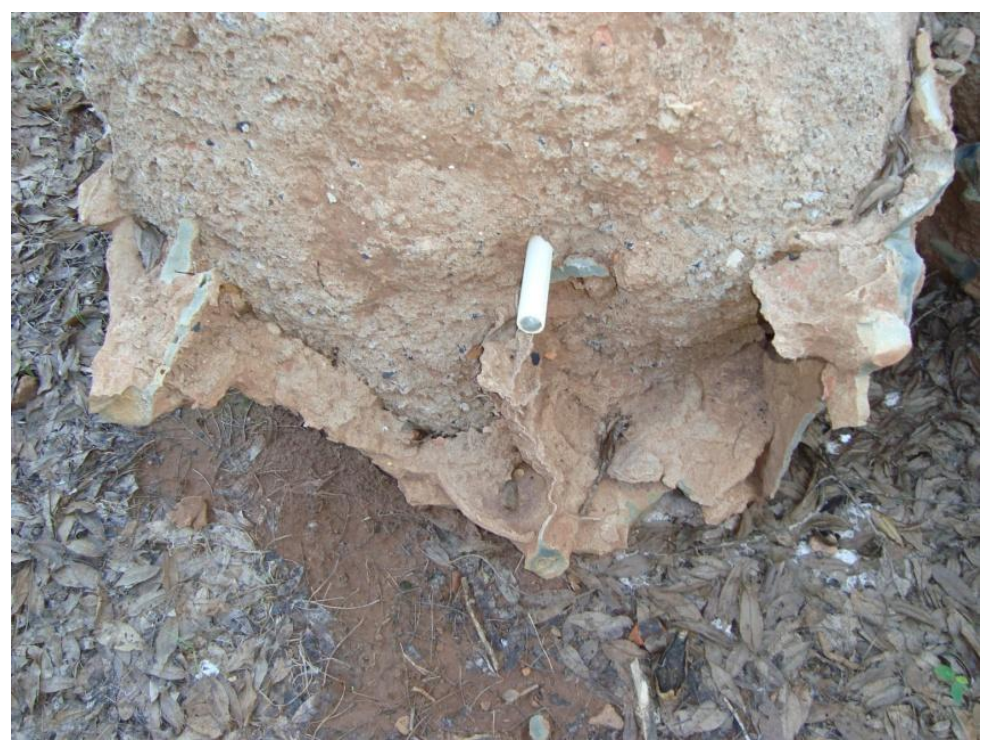

Figura 6.14 - Aumento do diâmetro do cilindro promovido pela injeção de calda (a) 


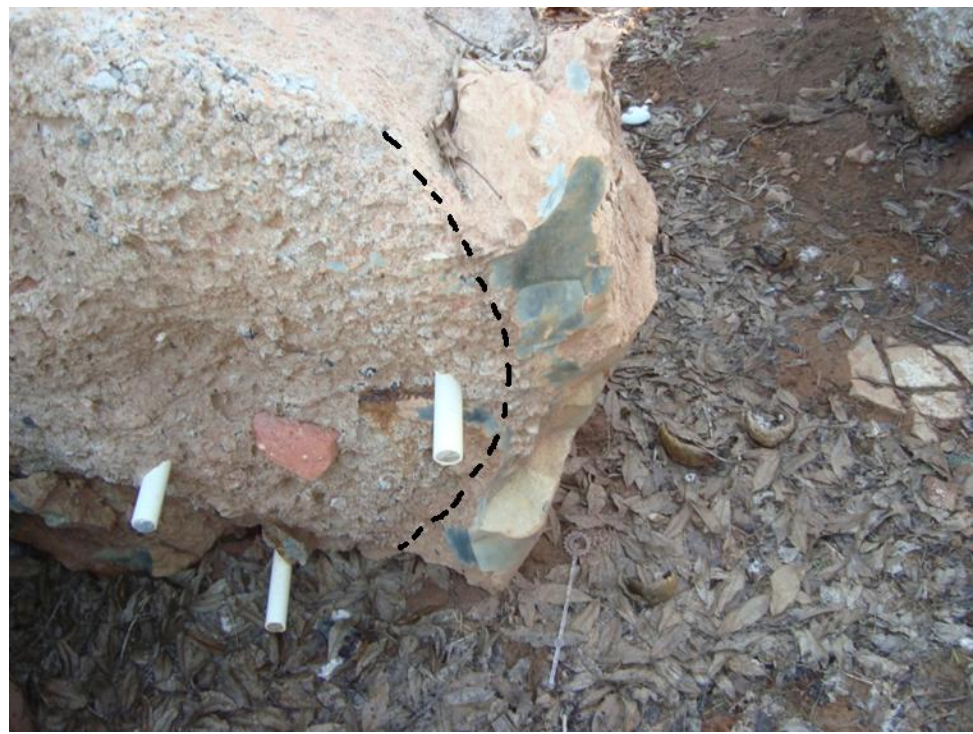

Figura 6.15 - Aumento do diâmetro do cilindro promovido pela injeção de calda (b)

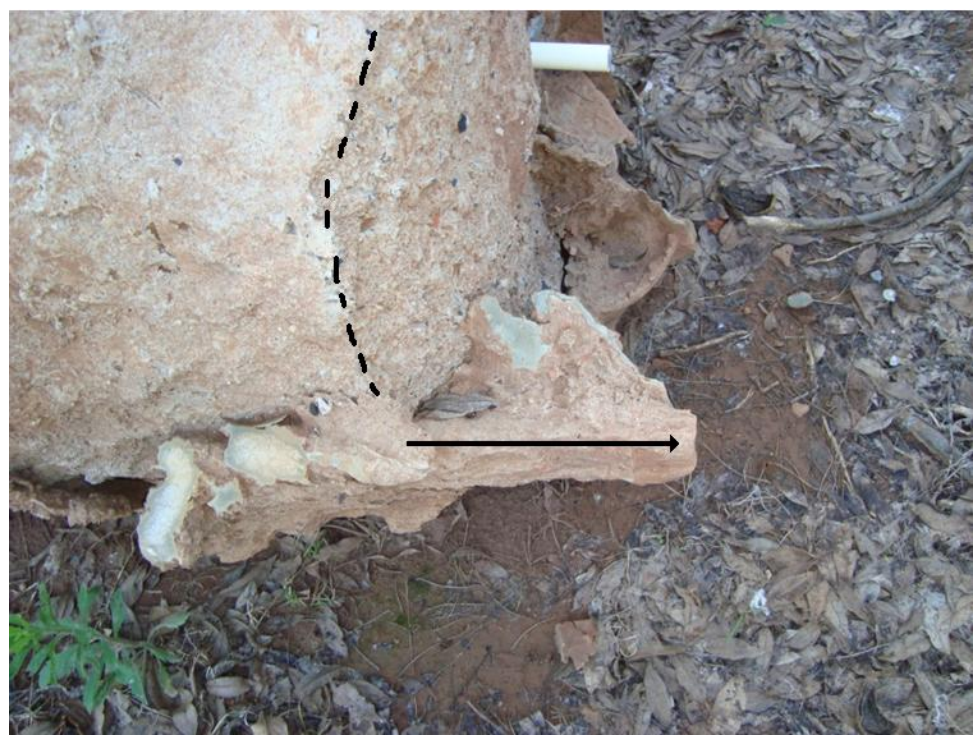

Figura 6.16 - Calda projetada para baixo 


\subsection{PROVAS DE CARGA NAS ESTACAS}

Nas Figuras 6.17 e 6.18 são mostradas as curvas carga-recalque obtidas nas sete provas de carga realizadas nas cinco estacas, sendo três delas com terreno previamente inundado, juntamente com os resultados das provas de carga realizadas por Carneiro (1999), em tubulões com base alargada de 1,5 m de diâmetro e sem base alargada. Os comprimentos das estacas e tubulões são iguais a $8 \mathrm{~m}$.

ENSAIOS NÃO INUNDADOS

A Figura 6.17 apresenta as curvas carga-recalque dos ensaios não inundados realizados nas estacas com base injetada $B, C, D$ e E, tubulões com base alargada de 1,5 m T5 e T6 (Carneiro, 1999) e tubulões sem base alargada T3 e T4 (Carneiro, 1999). É possível observar que o comportamento carga-recalque das estacas injetadas ficou em uma situação intermediária entre os tubulões sem base alargada e os com base de 1,5 m. 


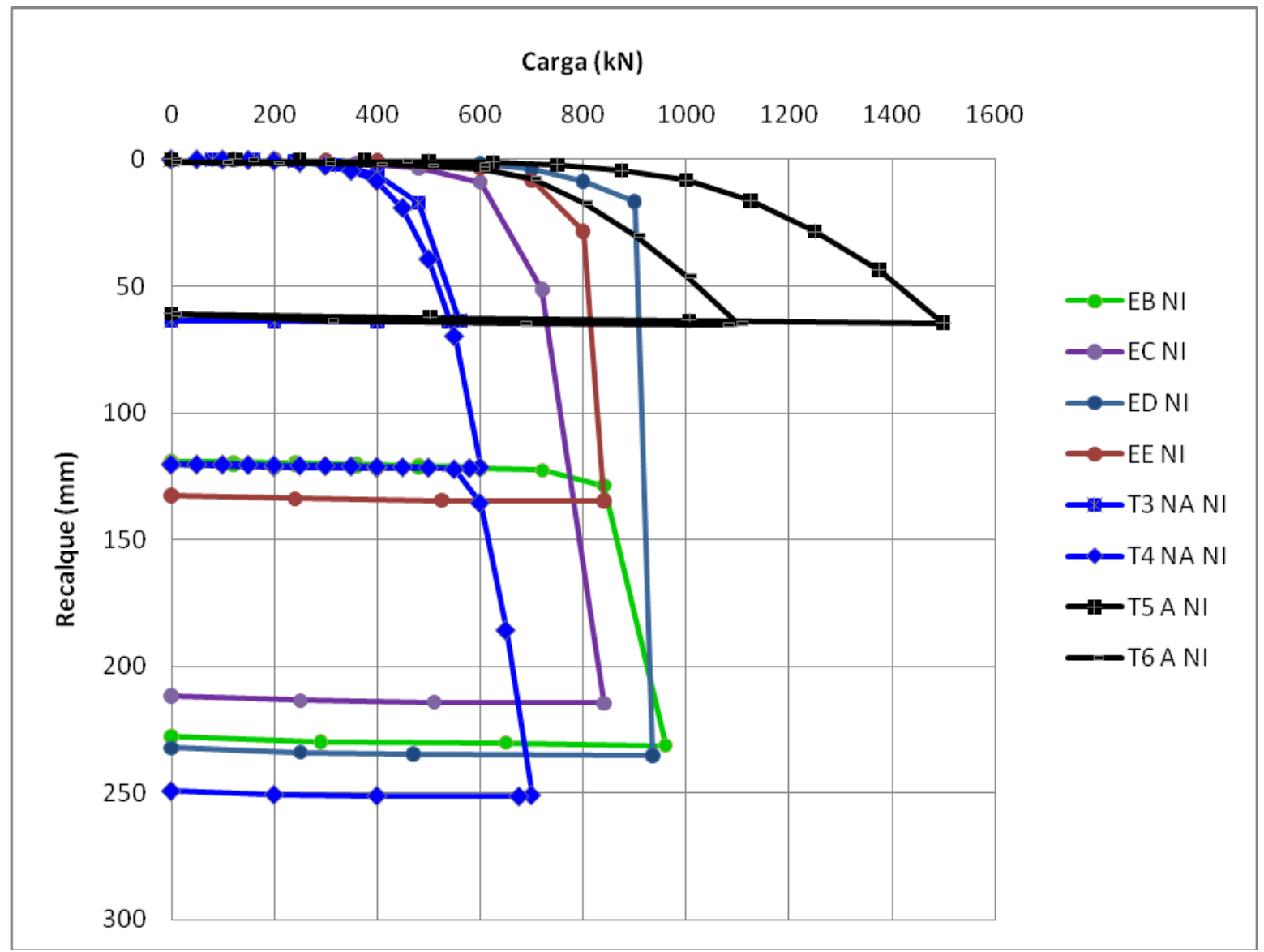

Figura 6.17 - Curvas carga $\times$ recalque dos ensaios não inundados (NI) realizados nas estacas $B, C, D$ e E (EB, EC, ED e EE) com base injetada, tubulões com base alargada de 1,5 m (A) T5 e T6 (Carneiro, 1999) e tubulões sem base alargada (NA) T3 e T4 (Carneiro, 1999)

ENSAIOS INUNDADOS

A Figura 6.18 apresenta as curvas carga-recalque dos ensaios inundados realizados nas estacas com base injetada A, B e E, tubulões com base alargada de 1,5 m T1, T2, T5 e T6 (Carneiro, 1999) e tubulão sem base alargada T3 (Carneiro, 1999). É possível observar que o comportamento carga-recalque das estacas injetadas B e E ficou em uma situação intermediária entre os tubulões sem base alargada e os com base de 1,5 m. 


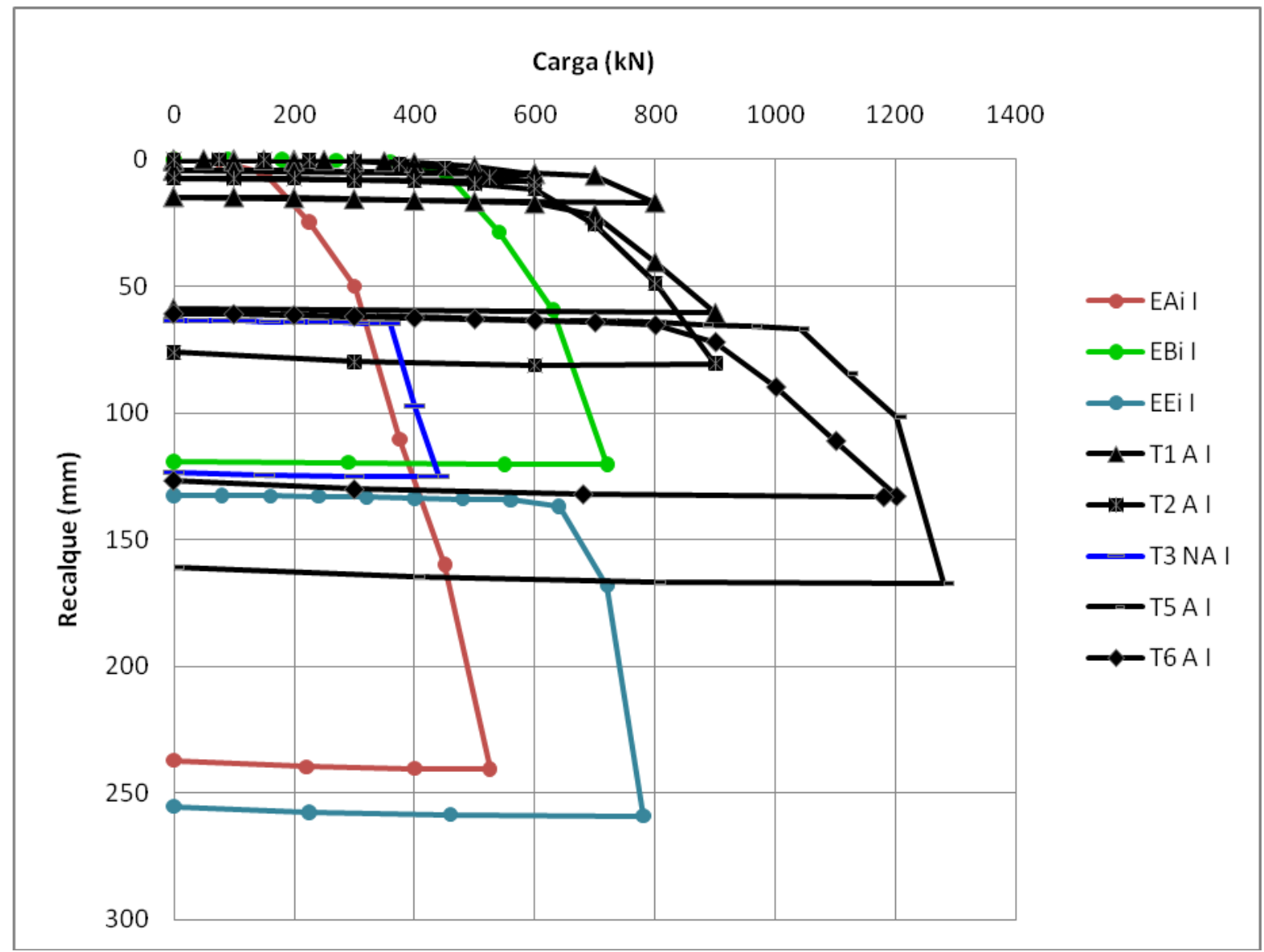

Figura 6.18 - Curvas carga x recalque dos ensaios inundados (I) realizados nas estacas A, B e E (EA, EB e EE) com base injetada, tubulões com base de 1,5 m (A) T1, T2, T5 e T6 (Carneiro, 1999) e tubulão sem base alargada (NA) T3 (Carneiro, 1999)

Para a estaca A, os valores de carga e recalque foram compatíveis com o tubulão sem base alargada e sem injeção. Dois fatores podem ter contribuído para tal: 1) A estaca foi construída no mesmo local onde antes havia sido feita uma escavação de $0,90 \mathrm{~cm}$ de diâmetro e $6 \mathrm{~m}$ de comprimento para ensaio de placa em profundidade e posterior reaterro. Isso pode ter anulado grande parte do atrito lateral. 2) Por causa dos entupimentos ocorridos durante a injeção, as pressões de injeção foram consideravelmente maiores que nas bases injetadas dos cilindros e nas estacas B, C, D e E, mas não suficientemente altas para fazer a calda injetada se comportar como um sólido. O risco de fraturamento hidráulico nesse caso é alto. 
CAPACIDADE DE CARGA

Adotando como critério de ruptura a carga relativa ao recalque igual a $10 \%$ do diâmetro do fuste das estacas e dos tubulões, $60 \mathrm{~mm}$, os seguintes são os valores de capacidade de carga para os ensaios realizados em terreno não inundado (Tabela 6.5) e com pré-inundação (Tabela 6.6):

Tabela 6.5 - Valores de capacidade de carga para os tubulões e estacas considerando um recalque igual a $60 \mathrm{~mm}$ - ensaios não inundados

\begin{tabular}{|c|c|c|}
\hline \multirow{2}{*}{ Estaca/Tubulão } & Base & $R(k N)$ \\
\hline EB & injetada $1 \mathrm{~m}^{3}$ & 760 \\
\hline EC & injetada $2 \mathrm{~m}^{3}$ & 730 \\
\hline $\mathrm{ED}$ & injetada $2 \mathrm{~m}^{3}$ & 910 \\
\hline $\mathrm{EE}$ & injetada $2 \mathrm{~m}^{3}$ & 810 \\
\hline T3 & não alargada & 550 \\
\hline T4 & não alargada & 530 \\
\hline T5 & alargada 1,5 m & 1470 \\
\hline T6 & alargada 1,5 m & 1070 \\
\hline
\end{tabular}

Tabela 6.6 - Valores de capacidade de carga para os tubulões e estacas considerando um recalque igual a $60 \mathrm{~mm}$ - ensaios inundados

\begin{tabular}{|c|c|c|}
\hline \multirow{2}{*}{ Estaca/Tubulão } & Base & $R(\mathrm{kN})$ \\
\hline $\mathrm{EA}$ & injetada $0,78 \mathrm{~m}^{3}$ & 310 \\
\hline $\mathrm{EB}$ & injetada $1 \mathrm{~m}^{3}$ & 630 \\
\hline $\mathrm{EE}$ & injetada $2 \mathrm{~m}^{3}$ & 640 \\
\hline $\mathrm{T} 1$ & alargada $1,5 \mathrm{~m}$ & 900 \\
\hline $\mathrm{T} 2$ & alargada $1,5 \mathrm{~m}$ & 840 \\
\hline $\mathrm{T} 3$ & não alargada & 350 \\
\hline $\mathrm{T} 5$ & alargada $1,5 \mathrm{~m}$ & 1150 \\
\hline $\mathrm{T} 6$ & alargada $1,5 \mathrm{~m}$ & 870 \\
\hline
\end{tabular}


Foi possível observar que nem sempre houve aumento da capacidade de carga com o aumento do volume de injeção.

Em média, a capacidade de carga das estacas injetadas é $49 \%$ maior que as dos tubulões sem base alargada e $37 \%$ menor que as dos tubulões com bases alargadas de 1,5 m de diâmetro, para o caso de terreno sem inundação prévia.

Para os ensaios inundados, em média, excluindo-se o resultado obtido para a estaca A, a capacidade de carga das estacas injetadas é $81 \%$ maior que as dos tubulões sem base alargada e 32\% menor que as dos tubulões com bases alargadas de 1,5 m de diâmetro.

A capacidade de carga dos ensaios não inundados foi, em média, $26 \%$ maior que as dos ensaios inundados. A diferença poderia ter sido ainda maior, se as provas de carga tivessem sido realizadas em época mais seca. O nível d'água à época das provas de carga estava em 8,25 m, e este pode chegar a $10 \mathrm{~m}$ de profundidade. A sucção matricial medida foi igual a $16 \mathrm{kPa}$. Em períodos mais secos este valor pode chegar a $40 \mathrm{kPa}$. A partir de agosto de 2009 até abril de 2010 o índice de chuvas foi atípico e superou todas as previsões do Instituto Nacional de Meteorologia. Agosto, que é tipicamente um mês seco na região de São Carlos, com precipitação média para o mês igual a 31 mm de chuva, teve, em 2009 , $160 \mathrm{~mm}$.

\section{COMPARAÇÃO COM ESTACAS ESCAVADAS}

Pode-se ainda comparar os resultados com os obtidos em provas de carga lenta em estacas escavadas de 0,35; 0,40 e 0,50 m de diâmetro, instaladas a uma profundidade igual a 10,60 m, executadas em pesquisa anterior por Mantilla (1992) (Figura 3.25). As capacidades de carga das estacas, aplicando o mesmo critério de ruptura $-10 \%$ do diâmetro da estaca - são apresentadas na Tabela 6.7. 
Tabela 6.7 - Valores de capacidade de carga para estacas considerando um recalque igual a 10\% do diâmetro - ensaios não inundados

\begin{tabular}{|c|c|c|}
\hline Estaca & Base & $R(k N)$ \\
\hline$E 0,35$ & não alargada $0,35 \mathrm{~m}$ & 330 \\
\hline$E 0,40$ & não alargada $0,40 \mathrm{~m}$ & 480 \\
\hline$E 0,50$ & não alargada $0,50 \mathrm{~m}$ & 480 \\
\hline
\end{tabular}

A Figura 6.19 apresenta os resultados de provas de carga não inundadas obtidos por Mantilla (1992) em estacas escavadas, juntamente com os de Carneiro (1999) para tubulões sem base alargada. É difícil fazer uma comparação direta, pois os diâmetros e comprimentos das estacas e tubulões são diferentes, mas as curvas parecem corroborar os resultados obtidos por Branco (2006), nos quais as capacidades de carga de estacas escavadas que tiveram o fundo da escavação limpos foram semelhantes aos que não tiveram limpeza. Tais trabalhos levam à conclusão que, somente a limpeza do fundo da escavação, não é suficiente para garantir o contato da ponta das estacas e tubulões com o solo e a transmissão dos esforços pela ponta sem a ocorrência de grandes recalques. 


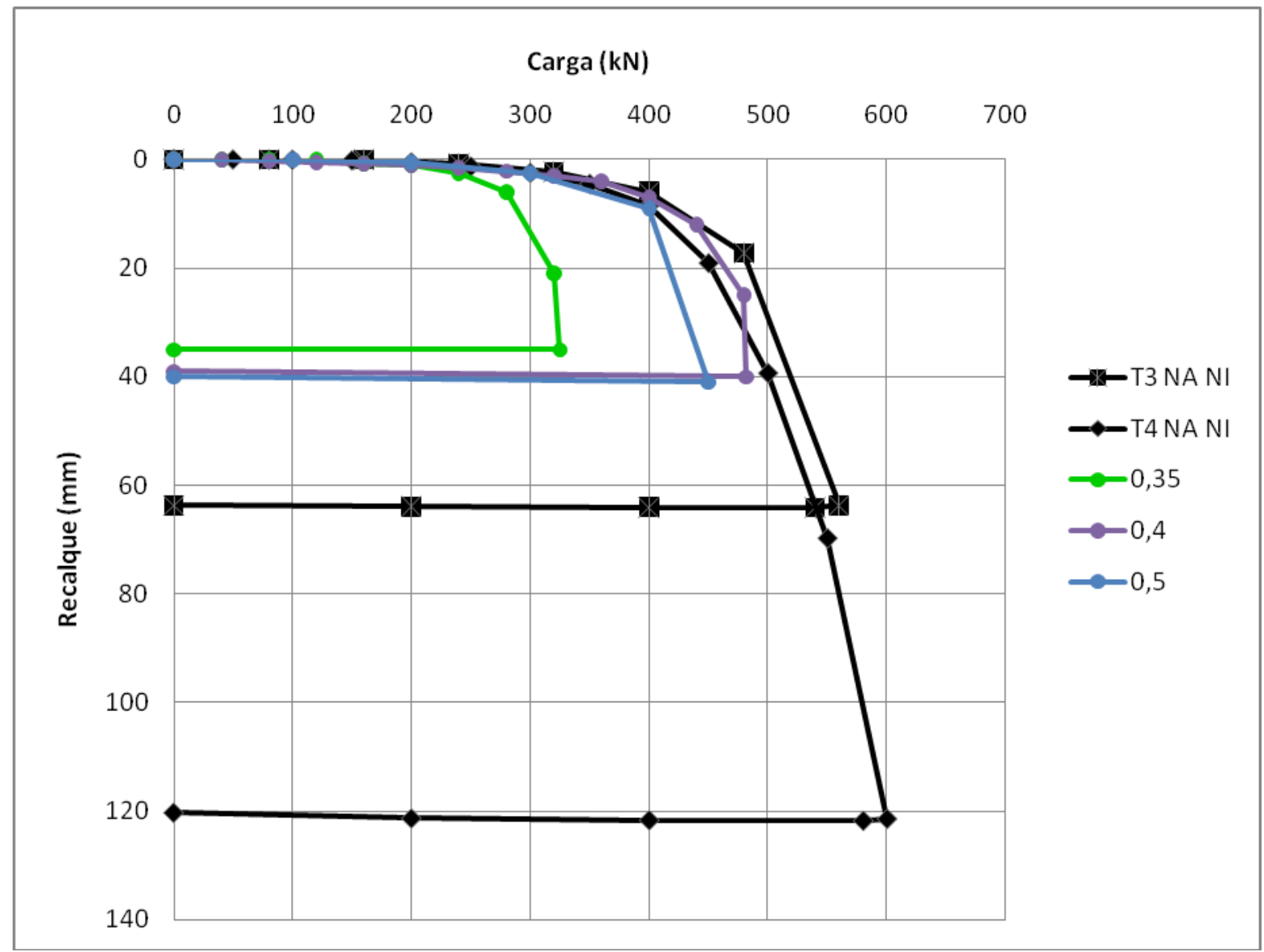

Figura 6.19 - Ensaios não inundados em estacas escavadas com 0,35, 0,40 e 0,50 m (Mantilla, 1992) e em tubulões com fuste de $0,60 \mathrm{~m}$ sem base alargada T3 e T4 (Carneiro, 1999)

Na Figura 6.20 são mostradas as curvas carga-recalque dos ensaios não inundados para as estacas com base injetada, juntamente com as curvas de Mantilla (1992) e Carneiro (1999) para tubulões sem base alargada. Observa-se que, para pequenos recalques, a mobilização de resistência é cerca de $50 \%$ maior para as estacas de base injetada.

No caso específico de estacas escavadas, A NBR 6122/96 afirma que a resistência de atrito prevista na ruptura não pode ser inferior a $80 \%$ da carga admissível (devido aos elevados recalques necessários para a mobilização da carga de ponta, quando comparados com os recalques necessários para a mobilização do atrito lateral, e por existirem dúvidas sobre a limpeza de fundo). As estacas escavadas com base injetada parecem garantir o contato entre a ponta da estaca e o solo. Por esse motivo, pode-se 
contar com uma parcela maior da resistência de ponta, o que pode viabilizar o uso de estacas escavadas em alguns casos nos quais os tubulões a céu aberto seriam a principal opção.

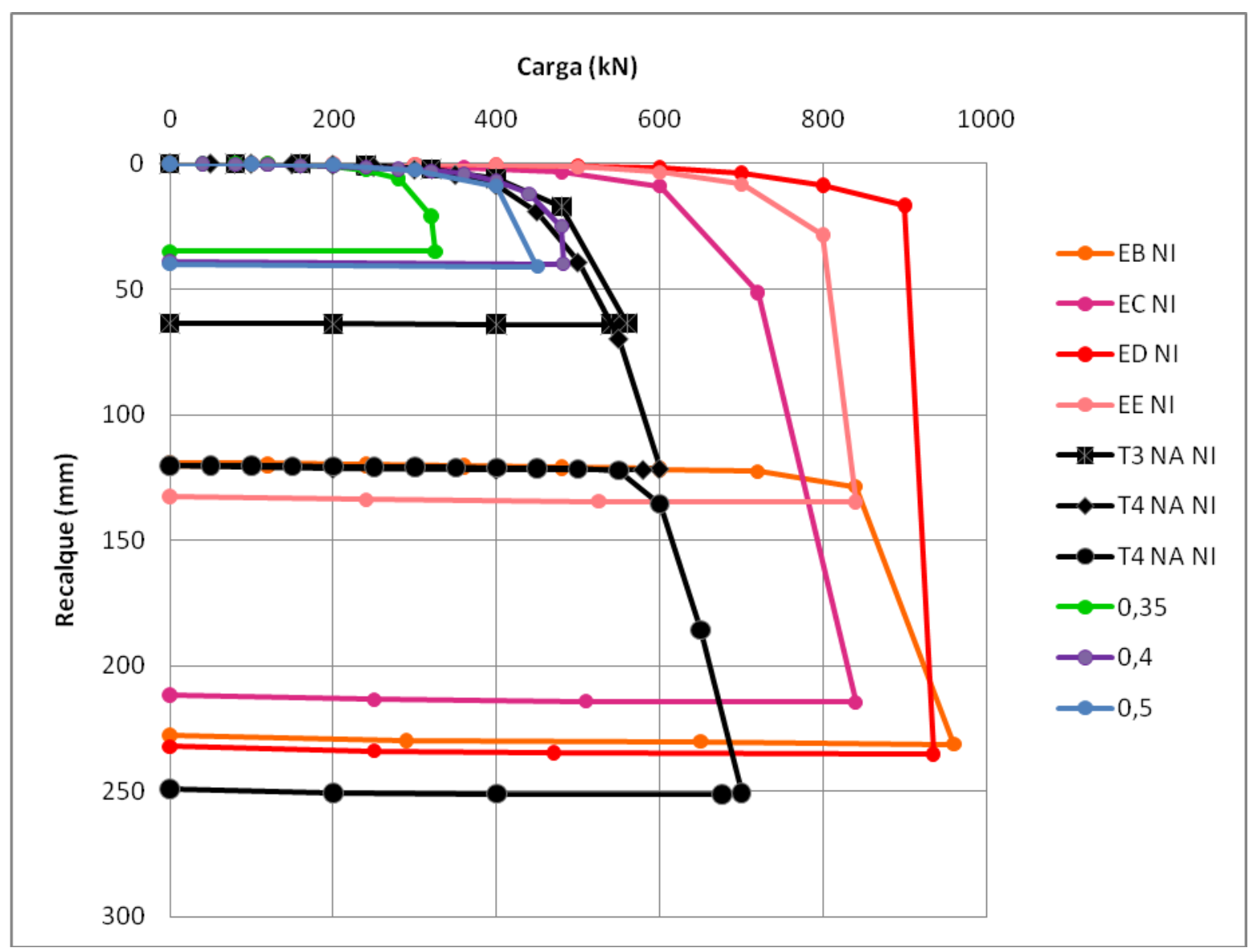

Figura 6.20 - Ensaios não inundados em estacas escavadas com 0,35, 0,40 e 0,50 m (Mantilla, 1992); em tubulões com fuste de $0,60 \mathrm{~m}$ sem base alargada T3 e T4 (Carneiro, 1999) e nas estacas escavadas com base injetada 


\subsection{PRECIPITAÇÃO, NÍVEL D'ÁGUA E TENSIOMETRIA}

A Figura 6.21 mostra as precipitações médias diárias para o período em que foram realizadas as provas de carga nas estacas de base injetada, juntamente com os valores de nível d'água, medidos no campo experimental de fundações. É possível observar o aumento da profundidade do nível d'água com a diminuição das chuvas.

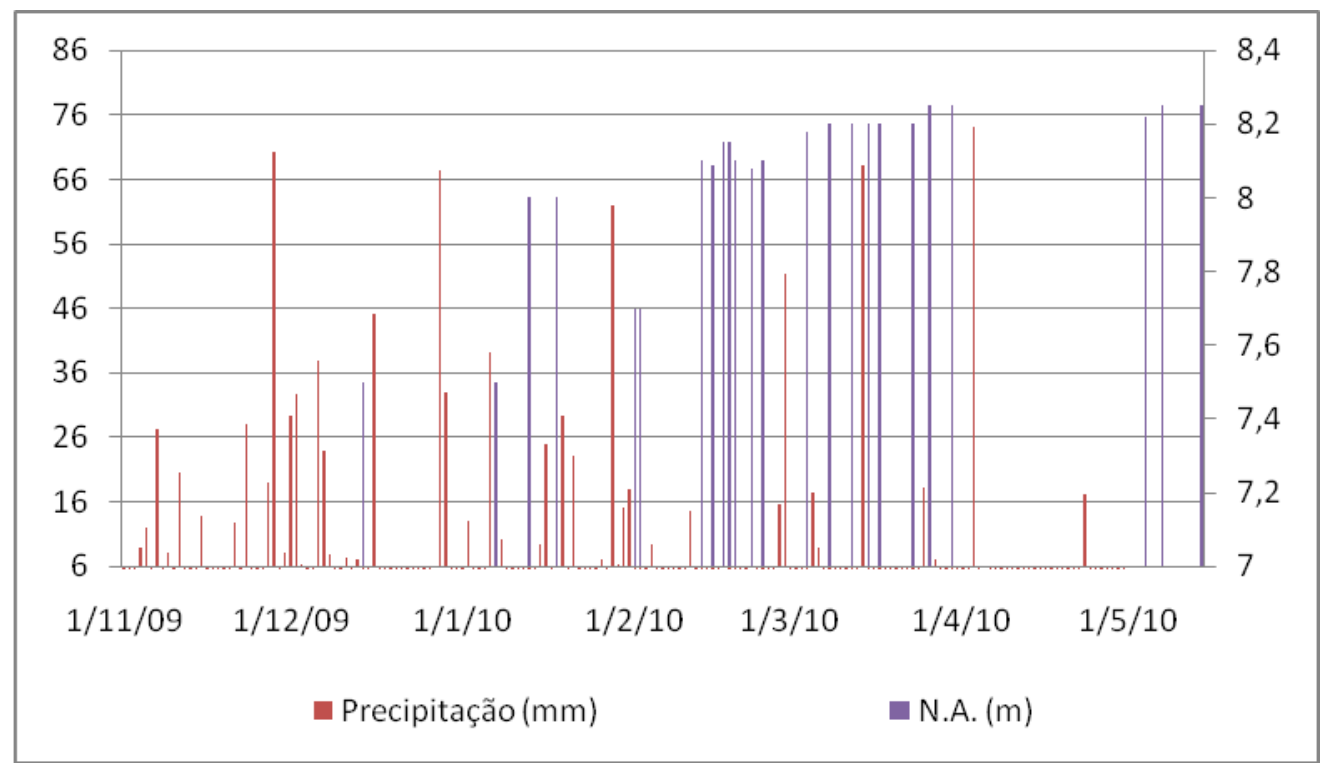

Figura 6.21 - Precipitação média diária e nível d'água

A Figura 6.22 mostra as precipitações médias diárias em conjunto com os valores de sucção matricial, medidos através de tensiômetro. É possível perceber a influência das chuvas na diminuição da sucção. 


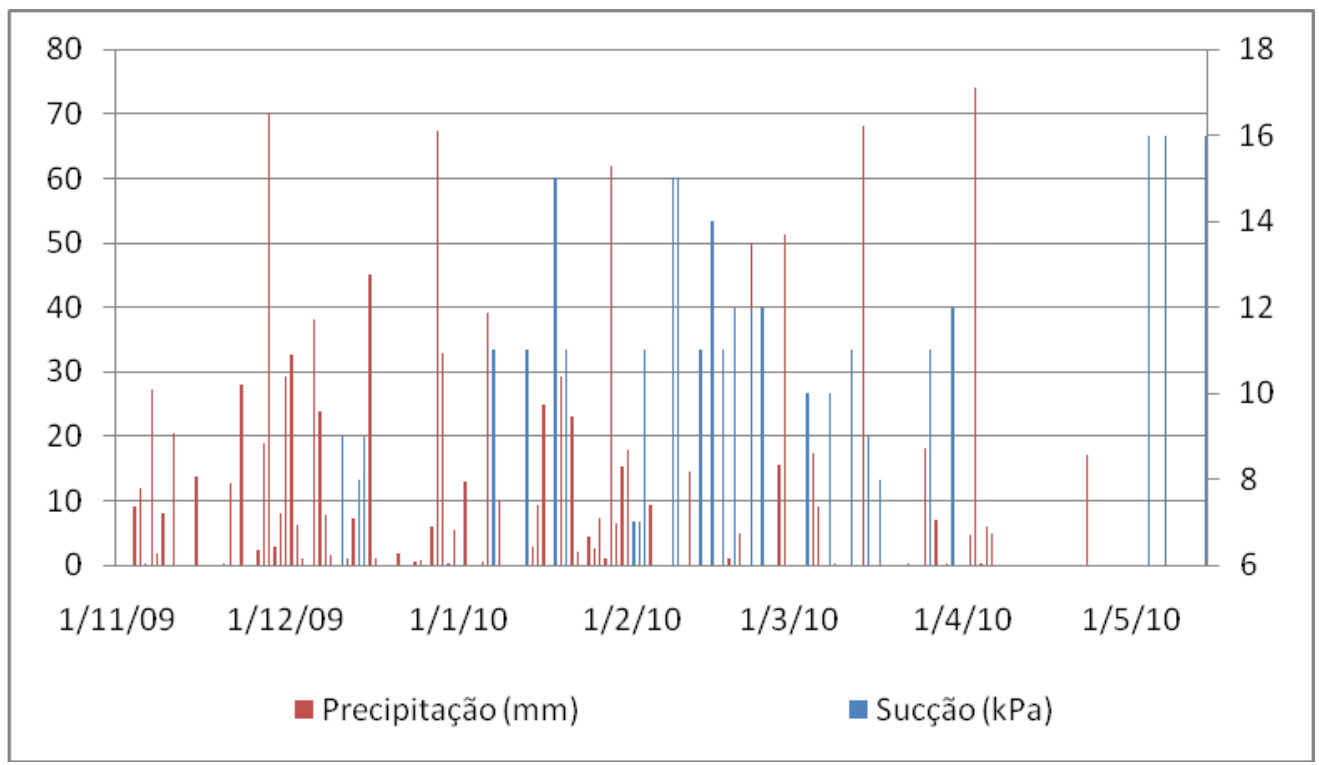

Figura 6.22 - Precipitação média diária e sucção matricial 


\section{CONCLUSÃO}

Esta tese contribui com a engenharia de fundações, testando e validando as estacas escavadas com base injetada. As injeções de calda de cimento sob a base das estacas promoveram aumento da capacidade de carga, passando a ser mais uma opção na escolha do tipo de fundação.

As conclusões obtidas nos estudos realizados são as seguintes:

\section{CILINDROS COM BASES INJETADAS}

Foram realizadas quatro provas de carga estática rápidas (QML) em quatro bases injetadas próximas à superfície, construídas sob cilindros de concreto com $1,8 \mathrm{~m}$ de profundidade e 0,80 m de diâmetro, no campo experimental de fundações da Escola de Engenharia de São Carlos da Universidade de São Paulo. Nas cavas onde foram concretados os cilindros e executadas as injeções, haviam sido realizadas provas de carga em placa em pesquisas anteriores por Costa (1999) e Moraes (2005).

Comparando-se as provas de carga realizadas nas bases injetadas sob os cilindros com os ensaios realizados em placa anteriormente, foi observado um aumento considerável da capacidade de carga. A comparação direta foi possível, pois todo o solo em volta do cilindro de concreto foi removido, eliminando-se assim o atrito lateral. As áreas das bases dos cilindros são iguais às da placa: $0,5 \mathrm{~m}^{2}$. Os aumentos de capacidade de carga constatados após as injeções foram de 33\%, 67\%, $11 \%$ e 21\% para as bases injetadas das cavas 4, 9, 7 e 8 respectivamente. Este é o aumento em relação à projeção dos dados da primeira prova de carga realizada em cada cava, adotando-se o critério de ruptura convencional no qual a resistência é a tensão que provoca um recalque de $25 \mathrm{~mm}$.

Os volumes de calda injetados sob os cilindros foram iguais a $0,17 \mathrm{~m}^{3} ; 0,2 \mathrm{~m}^{3} ; 0,14 \mathrm{~m}^{3}$; $0,2 \mathrm{~m}^{3}$ para as cavas 4, 9, 7 e 8 respectivamente. 
Foi observado que não é necessária a colocação de um pórtico sobre o cilindro para aumentar a força de reação e impedir que este se desloque para cima. Apesar de a calda entrar em contato com grande parte da área da base do cilindro, não houve deslocamento deste, pois o solo não oferece a reação necessária.

Com a extração dos cilindros constatou-se que as injeções se deram predominantemente por compactação, e não houve permeação ou mistura da calda com o solo.

\section{ESTACAS COM BASES INJETADAS}

Foram construídas 5 estacas escavadas com diâmetro igual 0,60 m e comprimento igual $8 \mathrm{~m}$. Nas bases das estacas, após a cura do concreto, foram executadas injeções de calda de cimento. O volume injetado foi igual a $0,78 \mathrm{~m}^{3}$ para a estaca A, $1 \mathrm{~m}^{3}$ para a estaca B e $2 \mathrm{~m}^{3}$ para as estacas C, D e E. Após a cura das injeções, as estacas foram ensaiadas através de provas de carga estática do tipo lenta (SML). Três dos ensaios foram realizados com inundação prévia do terreno.

As provas de carga foram comparadas com outras realizadas em pesquisas anteriores em 6 tubulões com $8 \mathrm{~m}$ de comprimento e fuste de $0,60 \mathrm{~m}$, sendo 4 com base alargada de 1,5 m de diâmetro e 2 sem base alargada.

Para a estaca A (ensaio inundado) os valores de carga foram compatíveis com o tubulão sem base alargada e sem injeção, ou seja, não houve melhora na capacidade de carga com a injeção. Dois fatores podem ter contribuído para tal: 1) A estaca foi construída no mesmo local onde antes havia sido feita uma escavação de $0,90 \mathrm{~m}$ de diâmetro e $6 \mathrm{~m}$ de comprimento para ensaio de placa em profundidade e posterior reaterro. Isso pode ter anulado grande parte do atrito lateral; 2) Por causa dos entupimentos ocorridos durante a injeção, as pressões de injeção foram consideravelmente maiores que nas bases injetadas dos cilindros e nas estacas $B, C, D$ e E, mas não suficientemente altas para fazer a calda 
injetada se comportar como um sólido. O risco de fraturamento hidráulico nesse caso é alto.

Em média, a capacidade de carga das estacas injetadas é $49 \%$ maior que as dos tubulões sem base alargada e $37 \%$ menor que as dos tubulões com bases alargadas de 1,5 m de diâmetro, para o caso de terreno sem inundação prévia.

Para os ensaios inundados, em média, excluindo-se o resultado obtido para a estaca A, a capacidade de carga das estacas injetadas é $81 \%$ maior que as dos tubulões sem base alargada e 32\% menor que as dos tubulões com bases alargadas de 1,5 m de diâmetro.

Não foram observadas diferenças significativas entre as curvas carga-recalque obtidas para a estaca B, injetada com $1 \mathrm{~m}^{3}$ de calda de cimento e as estacas $C, D$ e $E$, injetadas com $2 \mathrm{~m}^{3}$ de calda.

No caso específico de estacas escavadas, A NBR 6122/96 afirma que a resistência de atrito prevista na ruptura não pode ser inferior a $80 \%$ da carga admissível (devido aos elevados recalques necessários para a mobilização da carga de ponta, quando comparados com os recalques necessários para a mobilização do atrito lateral, e por existirem dúvidas sobre a limpeza de fundo). As estacas escavadas com base injetada garantem o contato entre a ponta da estaca e o solo. Por esse motivo, pode-se contar com uma parcela maior da resistência de ponta, o que pode viabilizar o uso de estacas escavadas em alguns casos nos quais os tubulões a céu aberto seriam a principal alternativa. 


\section{REFERÊNCIAS BIBLIOGRÁFICAS}

ABEF (2004). Manual de Especificações de Produtos e Procedimentos. PINI, São Paulo, $410 \mathrm{p}$.

ABELEV, Y. M. \& ASKALONOV, V. V. (1957). The stabilization of foundations of structures on loess soils. In: IV INTERNATIONAL. CONFERENCE ON SOIL MECHANICS AND FOUNDATION ENGINEERING, London, v. 1, p. 259-263.

ABNT (1991). Estacas - Prova de Carga Estática. NBR 12131, Rio de Janeiro, 4 p.

ABNT (1996). Estacas - Projeto e Execução de Fundações. NBR 6122, Rio de Janeiro, 33 p.

BARRADAS, S.S (1985). Iniciação e propagação de fraturas induzidas por injeções em solos argilosos com canalículos: aplicação ao tratamento do solo residual de fundação da barragem de terra da usina hidrelétrica de Balbina, AM. Rio de Janeiro. 298p. Dissertação (Mestrado) - COPPE, Universidade Federal do Rio de Janeiro.

BENVENUTTI, M. (2001). Cravação de Tubulões a Céu Aberto para Melhoria da Capacidade de Carga em Solos Colapsíveis. São Carlos. 115 p. Dissertação de Mestrado. Escola de Engenharia de São Carlos. Universidade de São Paulo.

BJERRUM, L.; NASH, J.K.T.L.; KENNARD, R.M.; GIBSON, R.E. (1972). Hydraulic fracturing in filed permeability testing. Geotechnique. v. 22, p.319-332.

BORTOLUCCl, A. A. (1983). Caracterização geológico-geotécnica da região urbana de São Carlos - SP. São Carlos. 67 p. Dissertação de Mestrado. Escola de Engenharia de São Carlos. Universidade de São Paulo.

BOTTIAU, M. (1993). Influence of the concreting on the bearing capacity. In: DEEP FOUNDATIONS ON BORED AND AUGER PILES, Rotterdam, p. 179-183. 
BRANCO, C. J. M. (2006) Provas de carga dinâmica em estacas escavadas de pequeno diâmetro com ponta modificada. Tese (Doutorado em Geotecnia [S.Carlos]) Escola de Engenharia de São Carlos.

BROMS, B. B.; CHANG, M. F.; GOH, A. T. C. (1988). Bored piles in residual soil and weathered rocks in Singapore. In: DEEP FOUNDATIONS ON BORED AND AUGER PILES, Ghent, P. 17-33.

BUTLER, H. D.; HOY, H. E. (1977). User's manual for the Texas quick-load method for foundation load testing. Federal Highway Administration. Office of development. Washington. 59 p.

CAMPELO, N. S. (1994) Comportamento de Estacas Submetidas A Esforços de Tração Em Solo Colapsível. 1994. Dissertação (Mestrado em Geotecnia [S.Carlos]) - Escola de Engenharia de São Carlos, Coordenação de Aperfeiçoamento de Pessoal de Nível Superior. Orientador: Jose Carlos Angelo Cintra.

CAMPELO, N. (2000). Comportamento de Tubulões Escavados a Céu Aberto, Submetidos a Carregamentos Dinâmicos, em Solo Colapsível. São Carlos. 319 p. Tese de Doutoramento. Escola de Engenharia de São Carlos. Universidade de São Paulo.

CAMPOS, L. E. P.; MENEZES, M. S. S.; PRESA, E. P.; FONSECA, E. C. (1994). Considerações Sobre a Análise de Estabilidade de Taludes em Solos Não Saturados. In: 20 SIMPÓSIO SOBRE SOLOS NÃO SATURADOS, Recife. Anais, v. 1, p. 249 a 252.

CARNEIRO, B. J. I. (1994) Comportamento de Estacas Apiloadas Em Solos Colapsíveis. Dissertação (Mestrado em Geotecnia [S.Carlos]) - Escola de Engenharia de São Carlos, Coordenação de Aperfeiçoamento de Pessoal de Nível Superior.

CARNEIRO, B. J. I. (1999) Comportamento de Tubulões a Céu Aberto, Instrumentados, em Solo não Saturado, colapsível. Tese (Doutorado em Geotecnia [S.Carlos]) - Universidade de São Paulo, Fundação de Amparo à Pesquisa do Estado de São Paulo. 
CARVALHO, D. (1991) Análise de cargas ultimas a tração de estacas escavadas, instrumentadas, em campo experimental de São Carlos - SP. Tese (Doutorado em Geotecnia [S.Carlos]) - Escola de Engenharia de São Carlos.

CHEN, S. G. \& HU, W. (2009) A Comprehensive Study on Subsidence Control Using COSFLOW. In: GEOTECHNICAL \& GEOLOGICAL ENGINEERING, vol. 27, p. 305 a 314.

CHIN, F. K. (1970). Estimation of the ultimate load of piles not carried to failure. In: II SOUTHEAST ASIAN CONFERENCE ON SOIL ENGINEERING. Proceedings. P. 81-90.

CINTRA, J. C. A. (1998). Fundações em Solos Colapsíveis. São Carlos, Serviço Gráfico da Escola de Engenharia de São Carlos, Universidade de São Paulo.

CINTRA, J. C. A. \& AOKI, N. (2009). Projeto de Fundações em Solos Colapsíveis. São Carlos, Serviço Gráfico da Escola de Engenharia de São Carlos, Universidade de São Paulo.

CINTRA, J. C. A.; CARVAlHO, D.; GIACHETt, H. L.; BORTOlluCl, A. A.; AlBIERO, J. H. (1991). Campo Experimental de Fundações em São Carlos. In: II SEMINÁRIO DE ENGENHARIA DE FUNDAÇÕES ESPECIAIS, São Paulo. Anais, ABMS/ABEF, v. 1, p. 96 a 105.

COSTA, Y. D. J. (1999). Estudo do Comportamento de Solo Não Saturado Através de Provas de Carga em Placa. Dissertação de Mestrado. Escola de Engenharia de São Carlos. Universidade de São Paulo.

DAPP, S. MUCHARD, M., BROWN,D. (2006). Experiences with Base Grouted Drilled Shafts in the Southeastern United States. IN: DFI 10TH INTERNATIONAL CONFERENCE ON PILING FOUNDATIONS, Ghent, $10 \mathrm{p}$.

DAVISSON, M. T. (1972). High Capacity Piles. Proceedings of Lecture Series on Innovations in Foundation Construction. ASCE, Illinois Section. Chicago. p. 81-112 
DE BEER, E. E. (1967). Proefondervindelijke bijdrage tot de studie van het grensdraag vermogen van zand onder funderingen op staal. Tijdshrift der Openbar Werken van Beigie Nos.

EMBRAPA PECUÁRIA SUDESTE (2010). Dados meteorológicos. Disponível em: <http://www.cppse.embrapa.br/080servicos/dados-meteorologicos/tmp_tipo>.

DUARTE, V. M. (1990). Caracterização hidrogeotécnica e injeção de vedação: tentativa de padronização de alguns critérios e procedimentos. In: CONGRESO SUDAMERICANO DE MECANICA DE ROCAS, 3., Caracas, ISRM. p.253-262.

FELLENIUS, B. H. (1975). Test Load of Piles and New Proof Test Procedure. In: JOURNAL OF GEOTECHNICAL ENGINEERING DIVISION. ASCE, vol. 101, GT9, p. 855 a 869.

FELLENIUS, B. H. (1980). The Analysis of Results from Routine Pile Load Tests. In: GROUND ENGINEERING DIVISION. Foundations publication, Ltd., vol. 13, n. 6, p. 19 a 31.

FERNANDES, J. C. S. (1995) Grupos de Estacas Escavadas de Pequeno Diâmetro Em Solo Colapsível. Dissertação (Mestrado em Geotecnia) - Escola de Engenharia de São Carlos.

FREDLUND, D. G.; RAHARDJO, H. (1993). Soil Mechanics for Unsaturated Soils, New York, John Wiley \& Sons.

FREDLUND, D.G., and XING, A. (1994) "Equations for the soil-water characteristic curve" Canadian Geotechnical Journal Vol. 31, pp. 521-532

FULLER, F. M.; HOY, H. E. (1970). Pile load tests including quick-load test method, conational methods and interpretations. Highway Research Board, 333. p. 78-86.

GHIONNA, V. N.; JAMIOLKOWSKI, M.; LANCELLOTTA, R.; PEDRONI, S. (1993). Base capacity of bored piles in sands from in situ tests. In: DEEP FOUNDATIONS ON BORED AND AUGER PILES, Ghent, p. 67-75. 
GIACHETI, H. L.; ROHM, S. A.; NOGUEIRA, J. B.; CINTRA, J. C. A. (1993). Propriedades geotécnicas do sedimento cenozóico. In: FERREIRA, A. A.; NEGRO JUNIOR, A.; ALBIERO, J. H.; CINTRA, J. C. A. orgs. Solos do Interior de São Paulo. São Paulo, ABMS, USP/SC. Cap. 6, p. 143175.

GUIMARÃES FILHO, J.D. (1984). Consolidação de solos por injeções: discussão sobre uma prática bem sucedida mas que não está de acordo com as teorias clássicas existentes. Solos e Rochas: Revista Brasileira de Geotecnia, v.7, n.3, p.99-107.

GUSMÃO FILHO, J. A. (1994). Fundações em Solos Não Saturados. In: 2o SIMPÓSIO SOBRE SOLOS NÃO SATURADOS, Recife. Anais, v. 1, p. 217 a 230.

GLOSSOP, R. (1960). The invention and development of injection processes. Geotechhnic, London, vol. X, p. 255-279.

HACHICH, W.; FALCONI, F.; PRADO, C. M.; NEGRO JR, A.; AZEM, F. (2005). Grouting techniques for the stabilization of the foundations of a factory overlying karst. IN: INTERNATIONAL CONFERENCE ON SOIL MECHANICS AND GEOTECHNICAL ENGINEERING, Osaka, p. 1189-1192.

HAIMSON, B.C., FAIRHURST, C. (1967). Initiation and extension of hydraulic fractures in rocks. Society of Petroleum Enginners Journal, v.7, p.310-318.

HARTIKAINEN, J. \& GAMBIN, M. P. (1994). Deep foundations with soil excavation: bored piles, root piles, CFA, slurry trench walls. In: INTERNATIONAL. CONFERENCE ON PILING AND DEEP FOUNDATIONS, Ghent, p. 693-713.

HEYDENRYCH, R. A. \& DE BEER, J. H. (1975). The use of shaft foundations. In: VI REGIONAL CONFERENCE FOR AFRICA ON SOIL MECHANICS AND FOUNDATION ENGINEEERING, Durban, p. 161-165.

HUBBERT, M.K., WILLIS, D.G. (1957). Mechanics of hydraulic fracturing. Petroleum Transactions AIME, v.210, p.153-168. 
INFANTI JÚNIOR, N., NITTA, T. (1978). Considerações para reavaliação dos critérios de injeções de cimento. In: CONGRESSO BRASILEIRO DE GEOLOGIA DE ENGENHARIA, 2, São Paulo, 1978. Anais... São Paulo: ABGE, v.1, p.35-43.

INSTITUTO DE PESQUISAS TECNOLÓGICAS DO ESTADO DE SÃO PAULO. (1979). Injeções em basalto. Relatório final. São Paulo: Divisão de Geologia. (IPT. Relatório, 12.513).

INSTITUTO DE PESQUISAS TECNOLÓGICAS DO ESTADO DE SÃO PAULO. (1984). A importância da reologia na aplicação de caldas de cimento. São Paulo: Divisão de Engenharia Civil. (IPT. Relatório, 19.559).

IYOMASA, W.S., RODRIGUES, J.E. (2002). Fraturamento Hidráulico e Injeção de SoloCimento em Maciço Terroso. In: Solos e Rochas, São Paulo, Mai-Ago, p. 105-118

JENNINGS, J. E. \& KNIGHT, K. (1975). A guide to construction on or with materials exhibiting additional settlement due to "collapse" of grain structure. In: VII REGIONAL CONFERENCE FOR AFRICA ON SOIL MECHANICS AND FOUNDATION ENGINEERING. Durban, v. 1, p. 99-105.

JONES, G.K.(1963). Chemistry and flow properties of bentonite grouts. Grouts and drilling muds in engineering practice. Butterworths, London, p.22-28.

LIGGITT, E. J. (1992). Construction of underreamed piles in london clay in potentially unstable ground. In: PILING - EUROPEAN AND WORLDWIDE TRENDS, London, p. 156-162.

LIMA, F. M. A. (1999). Análise de Prova de Carga Dinâmica em Estacas Metálicas do Tipo Trilho. São Carlos. 92p. Dissertação de Mestrado. Escola de Engenharia de São Carlos, Universidade de São Paulo.

MACACARI, M. F. (2001) Variação da capacidade de carga com a sucção e profundidade em ensaios de placa em solo colapsível. Dissertação (Mestrado em Geotecnia [S.Carlos]) - Universidade de São Paulo. Orientador: Jose Carlos Angelo Cintra. 
MACHADO, S. L. (1998). Aplicação de Conceitos de Elastoplasticidade a Solos Não Saturados. Tese de Doutoramento. São Carlos. 351 p. Escola de Engenharia de São Carlos, Universidade de São Paulo.

MANOLIU, I.; STOICA, R.; CULITA, C. (1993). Case studies concerning installation of large diametre piles used in Romania. In: DEEP FOUNDATIONS ON BORED AND AUGER PILES, Ghent, p. 213-216.

MANTILLA, J. N. R. (1992) Comportamento de estacas escavadas, instrumentadas, a compressão. Tese (Doutorado em Geotecnia [S.Carlos]) - Escola de Engenharia de São Carlos.

MASSAD, F. (2002): "Novo Método para a Interpretação de Provas de Carga Cíclicas, Estáticas e Dinâmicas, em Estacas Verticais". In: XII Congresso Brasileiro de Mecânica dos Solos e Engenharia Geotécnica, vol. 3, São Paulo, Outubro, 2002, p. 1627 a 1638.

MAZURKIEWICZ, B. K. (1972). Test loading of piles according to Polish regulations. Royal Swedish Academy of Engineering Sciences. Report n. 35. Stockolm. 20 p.

MELLO, V. F. B. \& AOKI, N. (1973). Updating on large diameter bored piles. In: DEEP FOUNDATIONS ON BORED AND AUGER PILES, Ghent, p. 35-42.

MENEGOTTO, M. L. (2004) Previsão da curva tensão x recalque de ensaios de placa em solo não saturado. 219 f. Tese (Doutorado em Geotecnia [S.Carlos]) - Universidade de São Paulo, Coordenação de Aperfeiçoamento de Pessoal de Nível Superior. Orientador: Jose Carlos Angelo Cintra.

MEYERHOF, G. G. (1988). Some problems in predicting behavior of bored pile foundations. In: DEEP FOUNDATIONS ON BORED AND AUGER PILES, Ghent, p. 133-143.

MIGUEL, M. G. (1996) Execução e Analise de Provas de Carga Horizontal Em Estacas Em Solo Colapsível. Dissertação (Mestrado em Geotecnia [S.Carlos]) - Escola de Engenharia de São Carlos, Conselho Nacional de Desenvolvimento Científico e Tecnológico. 
MIKI. G. (1979). New construction and measurement method of bored piles with enlarged base. In: XII INTERNATIONAL. CONFERENCE ON SOIL MECHANICS AND FOUNDATION ENGINEERING, Rio de Janeiro, p. 27-42.

MORAES, L. S. (2005) Prova de carga dinâmica em placa. 142 f. Dissertação (Mestrado em Geotecnia [S.Carlos]) - Universidade de São Paulo, Conselho Nacional de Desenvolvimento Científico e Tecnológico.

MORETTO, O. (1975). Fundaciones de los puentes sobre el rio Parana en la Republica Argentina. In: $\vee$ CONGRESO PANAMERICANO DE MECANICA DE SUELOS E INGENIERIA DE FUNDACIONES. TOMO V, p. 133-179.

MORI, H. \& INAMURA, T. (1991). Construction of cast-in-place piles with enlarged bases. In: BURLAND, J. \& MICHEL, J. eds. Piling and deep foundations. Rotterdam, Balkema, p. 85-92.

MULLINS, G.; WINTERS, D.; DAPP, S. (2006). Predicting End Bearing Capacity of PostGrouted Drilled Shaft in Cohesionless Solis. JOURNAL OF GEOTECHNICAL AND GEOENVIROMENTAL ENGINEERING. Vol. 132, n. 4, April. ASCE.

NONVEILLER, E. (1989). Grouting, theory and practice, Amsterdam, New York, Elsevier, $250 \mathrm{p}$.

OLIVEIRA, M.; FERREIRA, A.A. (1982). Consolidação de solo aluvionar mole: relato de um tratamento por injeção de cimento para escavação de túnel urbano na cidade de São Paulo. In: SIMPÓSIO SOBRE ESCAVAÇÕES SUBTERRÂNEAS, Rio de Janeiro, 1982. Anais... São Paulo: ABMS, v.1, p.335-353.

REESE, L. C. (1978). Design and construction of drilled shafts. JOURNAL OF GEOTECHNICAL ENGINEERING DIVISION, GT1, p. 95-166, January. 
REZENDE, M. E. B. (1996) Analise de Recalques de Grupos de Estacas Escavadas de Pequeno Diâmetro Através de Provas de Carga In-Situ e Em Modelos Centrifugados. Tese (Doutorado em Geotecnia) - Escola de Engenharia de São Carlos.

SABARLY F. (1968). Les injections et les drainages de foundations de barrages en roches peu permeables. Geotechnique, v.18, n.2. p.229-249. Trad. de Guido Guidicini e Fernão Paes de Barros, 1971, São Paulo. (APGA. Boletim, 2).

SAMPAIO, A. J. M. (1988). O emprego de injeção de calda de cimento no tratamento de fundações basálticas de barragens do tipo concreto-gravidade no Brasil Meridional: aspectos práticos. São Carlos. 118p. Dissertação (Mestrado) - Escola de Engenharia de São Carlos, Universidade de São Paulo.

SANTOS, O. G. (1985). Experimental grouting of residual soil of the Balbina Earth Dam Foundation, Amazon, Brazil. In: INTERNATIONAL CONFERENCE ON GEOMECHANICS IN TROPICAL LATERITIC AND SAPROLITIC SOILS, 1., Brasília, 1985. Proceedings... São Paulo: ABMS, v.2, p.143-154.

SANTOS, T. R. S. (2001) Atrito Lateral e Resistência de Base em Tubulões a Céu Aberto em Solos Colapsíveis. Dissertação (Mestrado em Geotecnia) - Universidade de São Paulo.

SENNA JUNIOR, R. S. (1993) Distribuição de Carga Em Grupos de Estacas Escavadas de Pequeno Diâmetro. Dissertação (Mestrado em Geotecnia) - Escola de Engenharia de São Carlos.

SILVA, P. A. B. A. (1996) Capacidade de Carga de Grupos de Estacas Escavadas de Pequeno Diâmetro. 1996. Dissertação (Mestrado em Geotecnia) - Escola de Engenharia de São Carlos.

SOARES, F. L. (2002). Análise de Provas de Carga Dinâmica em Tubulões a Céu Aberto no Campo Experimental de Fundações da EESC/USP. São Carlos. 158 p. Dissertação de Mestrado. Escola de Engenharia de São Carlos, Universidade de São Paulo. 
TATAMIYA, C.T. et al.(1971). Ensaios in situ de injeção de caldas de cimento nas fundações da Usina de llha Solteira. In: SEMINÁRIO NACIONAL DE GRANDES BARRAGENS, 7. Anais. Rio de Janeiro: CBGB, v.1, p.196-199.

TEIXEIRA, C. Z. (1993) Comportamento de estacas escavadas em solos colapsíveis. Dissertação (Mestrado em Geotecnia) - Escola de Engenharia de São Carlos.

TEIXEIRA, A. H.; GODOY, N. S. (1998). Análise, projeto e execução de fundações rasas. In: HACHICH, W.; FALCONI, F.; SAES, J. L.; FROTA, R.; CARVALHO, C.; NIYAMA, S. eds. Fundações: teoria e prática. 2 ed. São Paulo, PINI. Cap.7, p. 227 a 264.

TEPARAKSA, W. (1992). Behavior of base-grouted bored piles in Bangkok subsoils. In: PILING - EUROPEAN AND WORLDWIDE TRENDS, London, p. 296-301.

TERZAGHI, K. (1943). Teorical Soil Mechanics. New York, Jonh Willey \& Sons.

TING, W. H. \& TOH, C. T. (1985). An instrumented bored pile with soil improvement for increased shaft resistance. IN: INTERNATIONAL CONFERENCE ON SOIL MECHANICS AND FOUNDATION ENGINEERING, San Francisco, p. 1482-1488.

VAN DER VEEN, C. (1953). The Bearing Capacity of a Pile. In: III INTERNATIONAL CONFERENCE ON SOIL MECHANICS AND FOUNDATION ENGINEERING. Zurich, v. 2, p. 84-90.

VAN IMPE, W. F. (1989). New trends and developments in middle europe. The association of civil engineers, Helsinki.

VAN WEELE, A. F. (1957): "A Method of Separating the Bearing Capacity of a Test Pile into Skin-friction and Point-resistance" - $4^{\text {th }}$ International Conference on Soil Mechanics and Foundation Engineering, vol. II, London, August, 2002, p.76-90. 
WANG, W. D. WU, J. B. e DI, G. E. (2006) Performance of Base Grouted Bored Piles in Specially Big Excavation Constructed using Top-down Method. IN: Underground Construction and Ground Movement (GSP 155) Part of GeoShanghai 2006 - Proceedings of Sessions of GeoShanghai 2006, Shangai, p. 393-400.

WARNER, P.E.J. (2004). Practical Handbook of Grouting - Soil, Rock and Structures, New Jersey, John Wiley \& Sons, $700 \mathrm{p}$. 